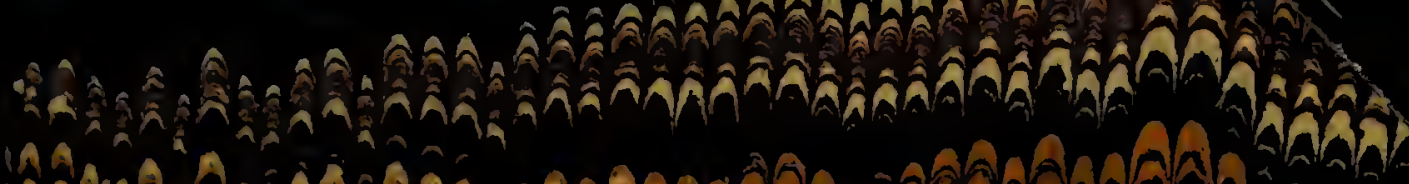

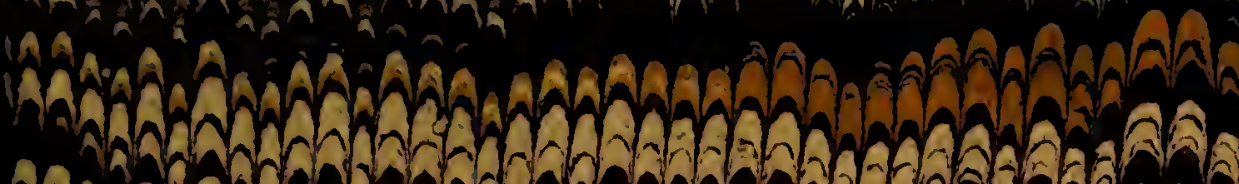

AคA A

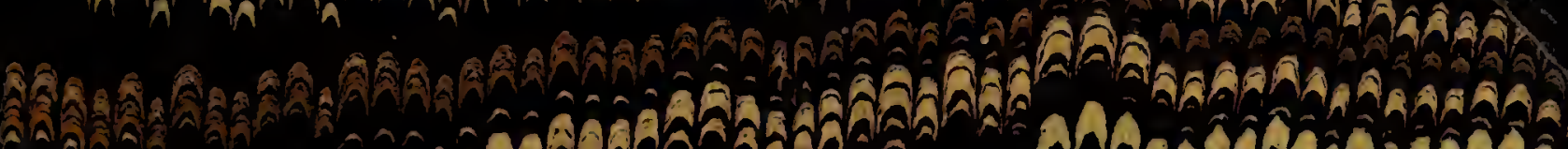

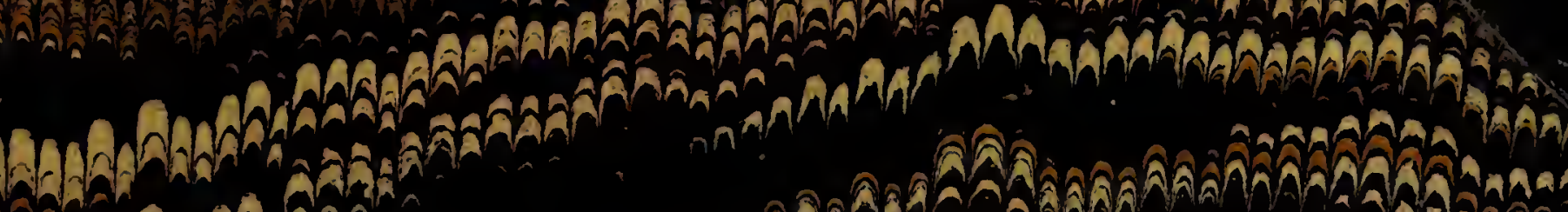

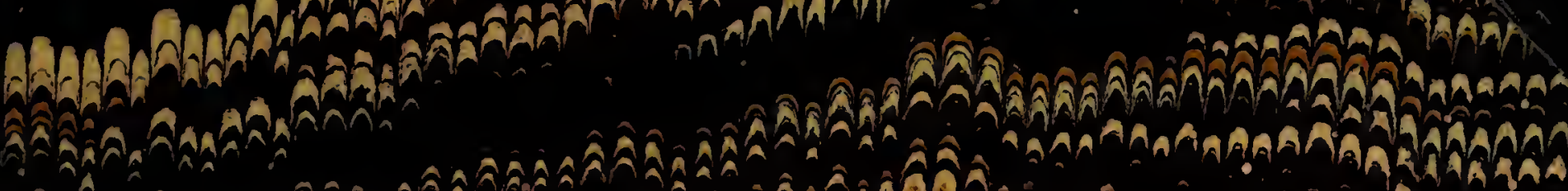
ÂA

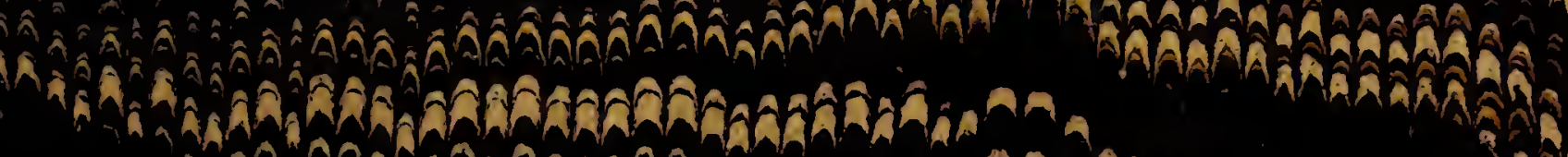

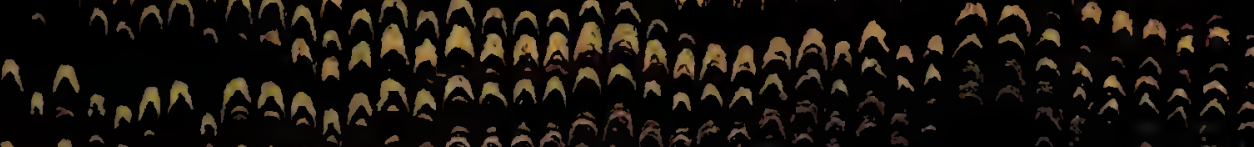

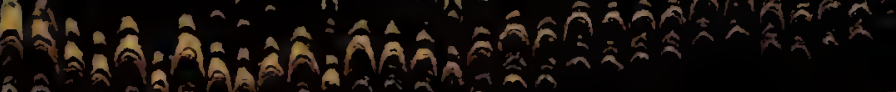

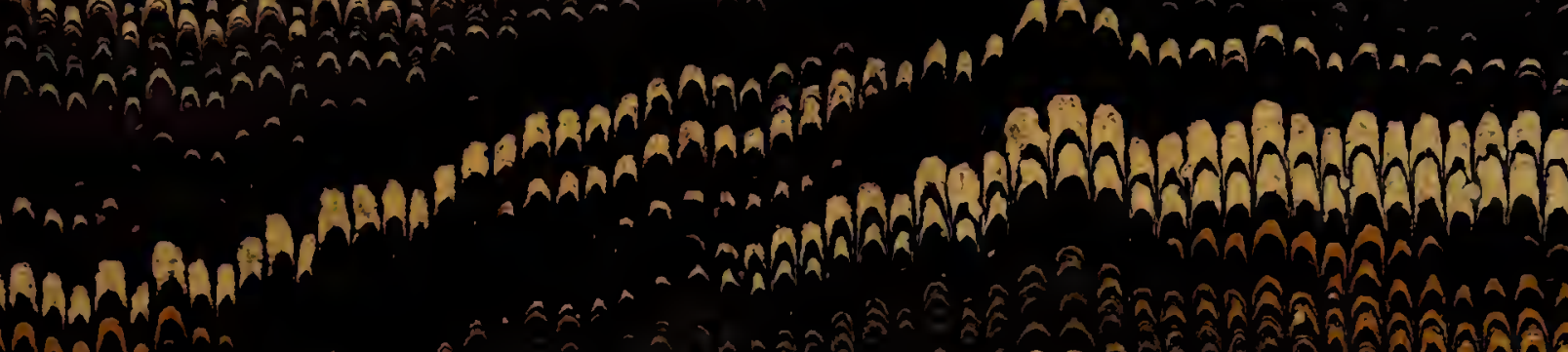
Warar

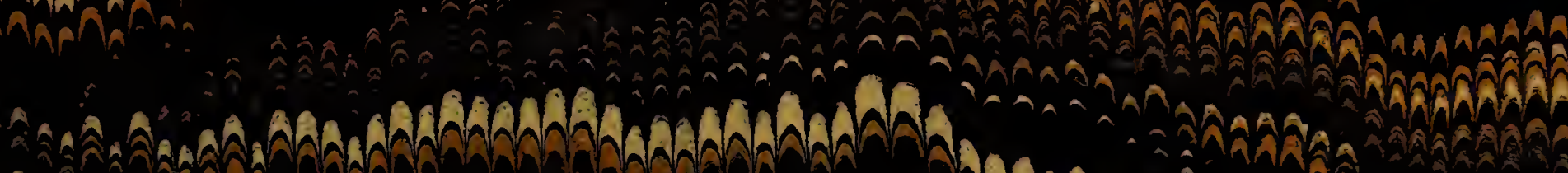

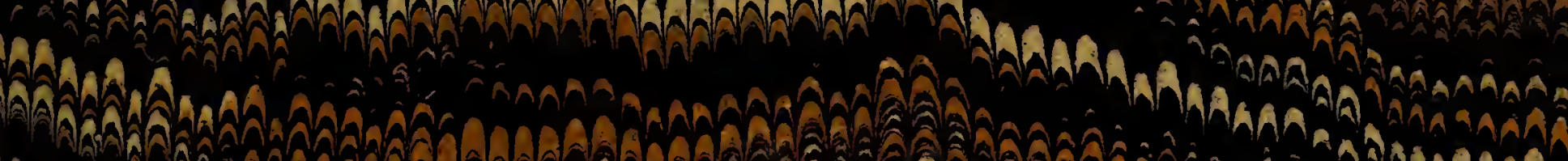

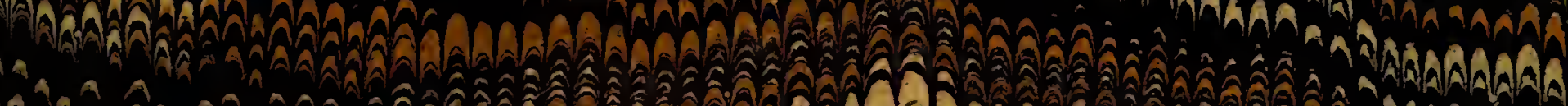

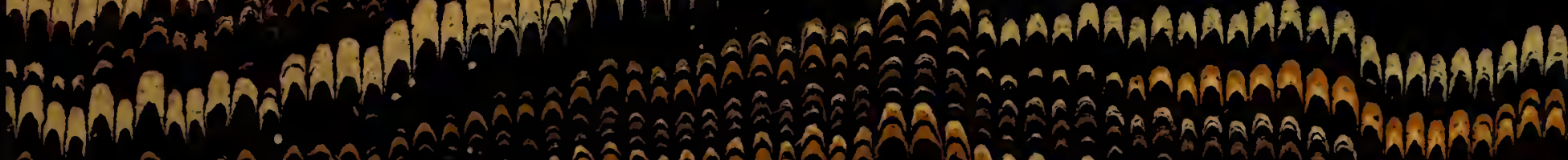

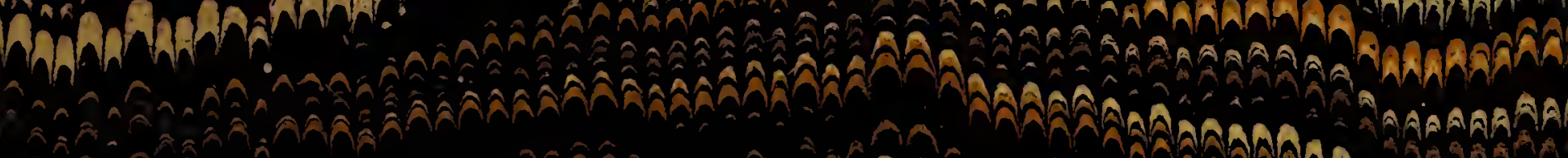

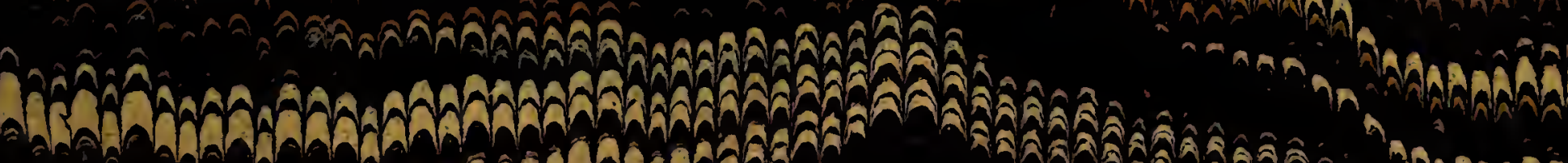

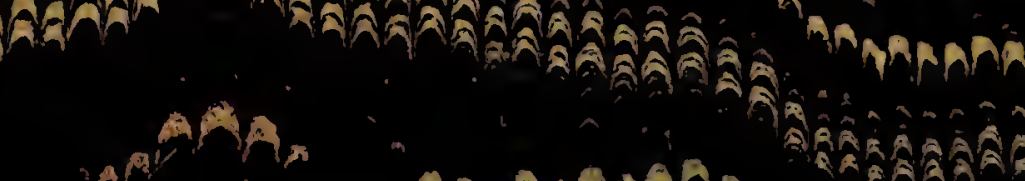

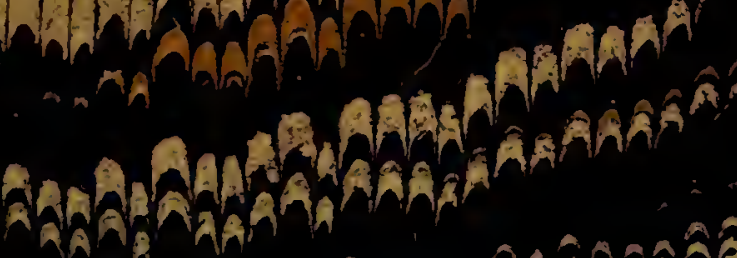

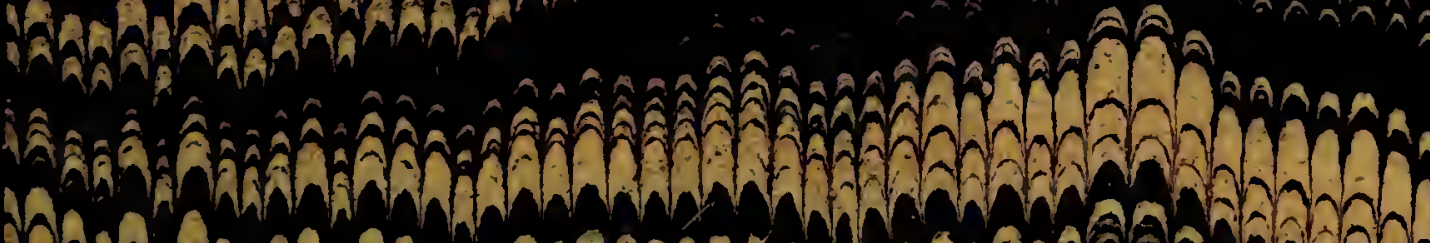

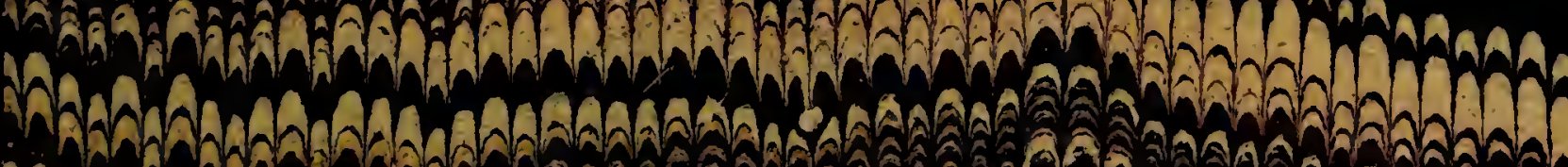

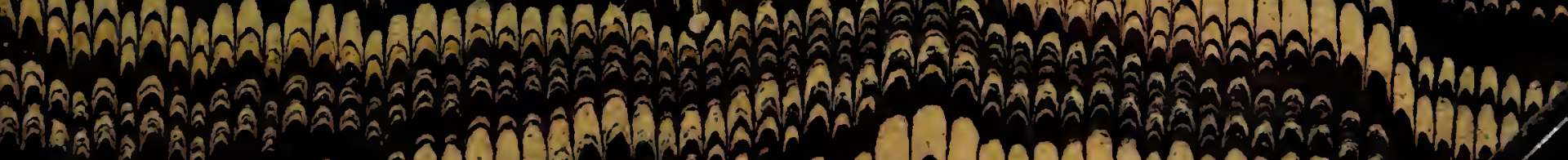

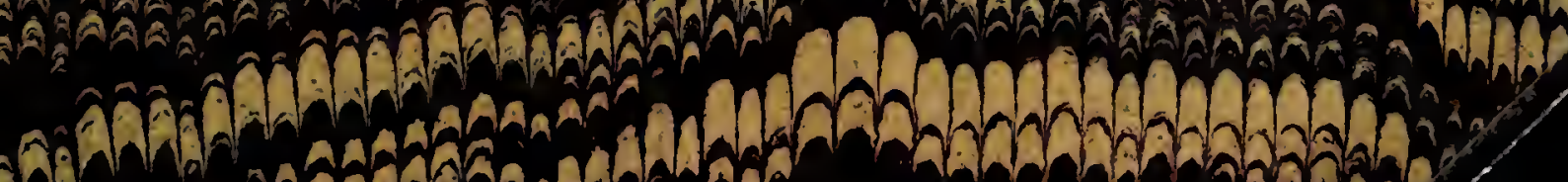

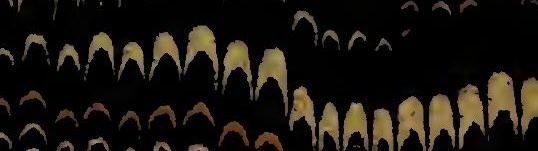
AN

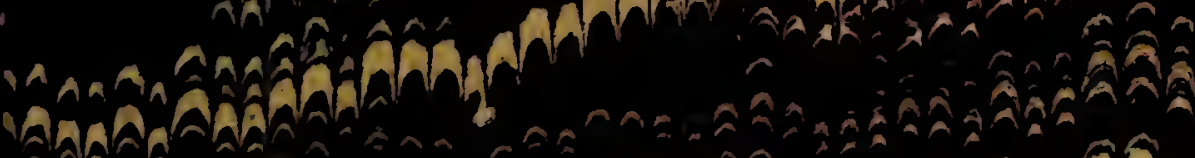

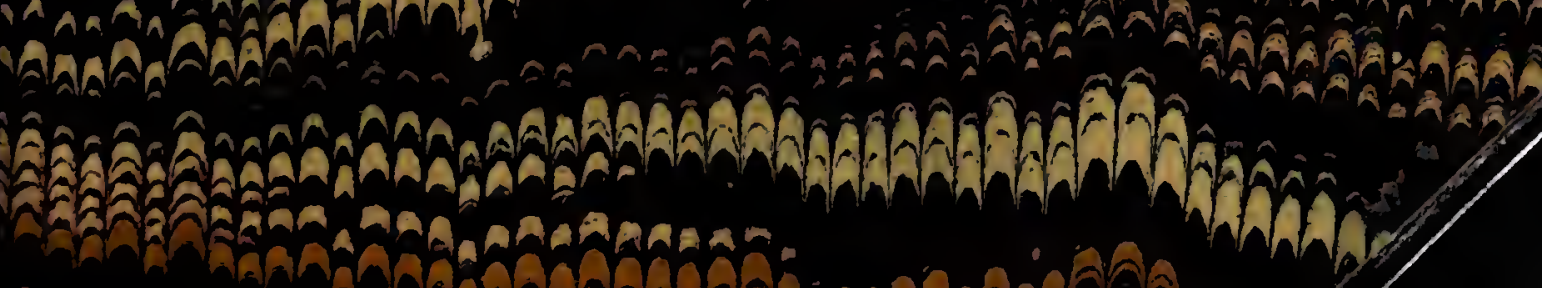

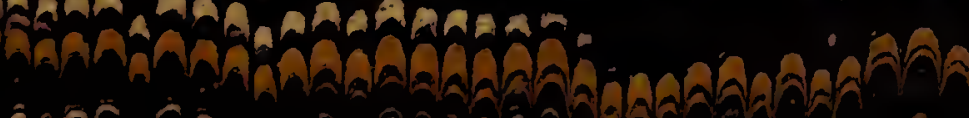




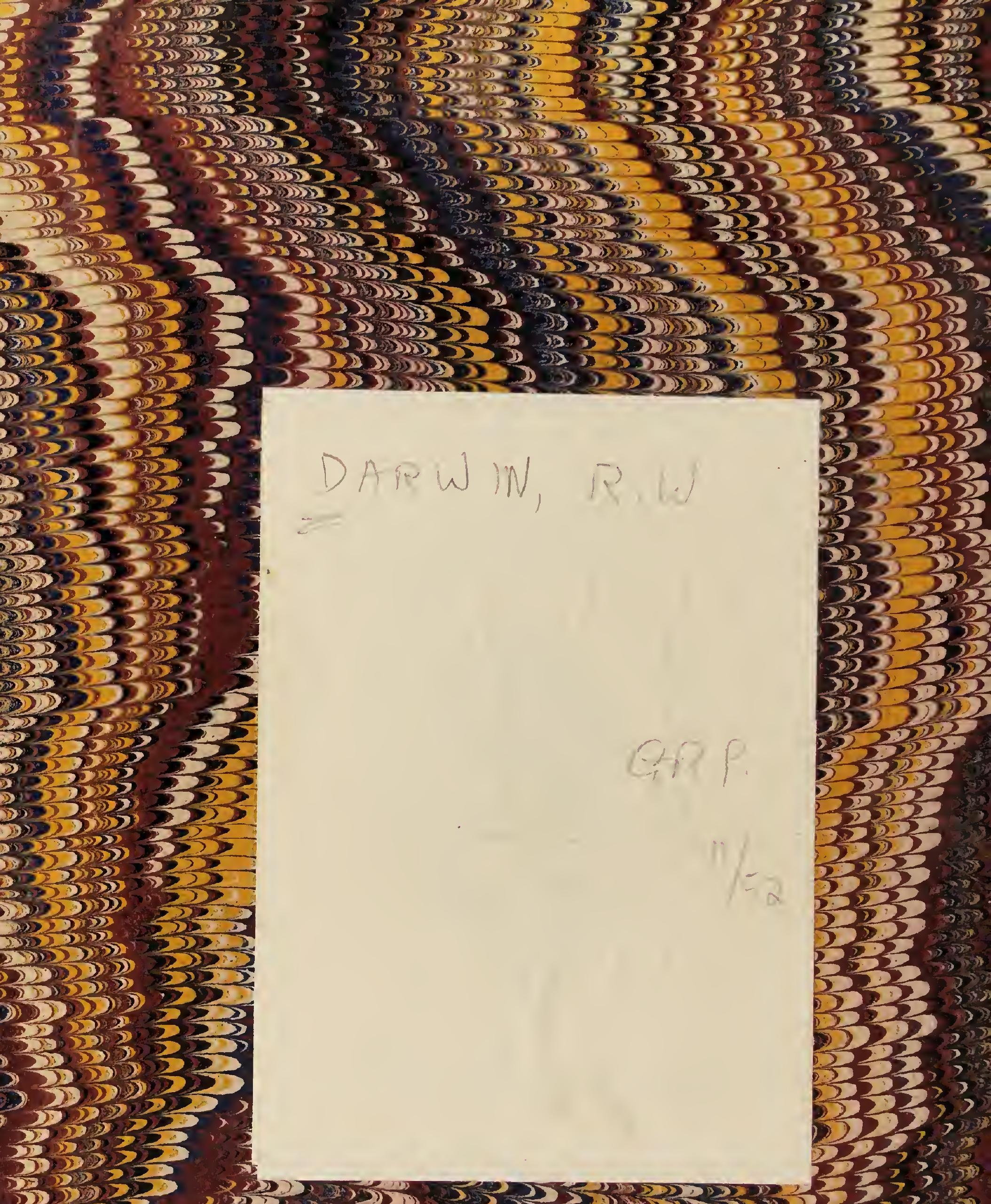

532102020

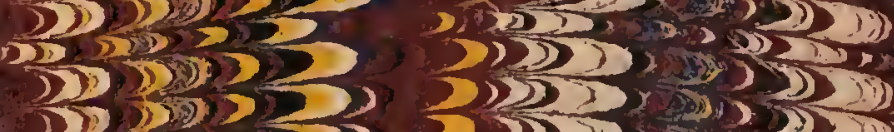

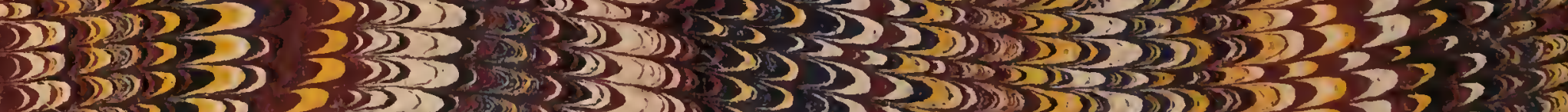

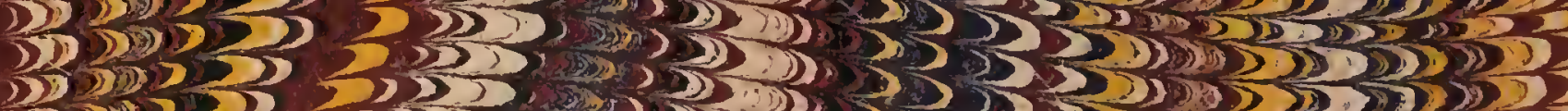

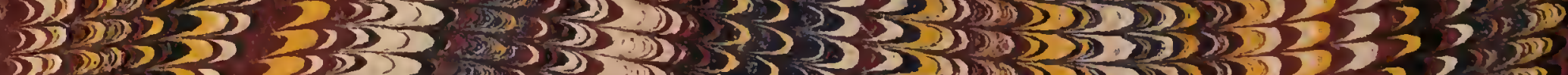

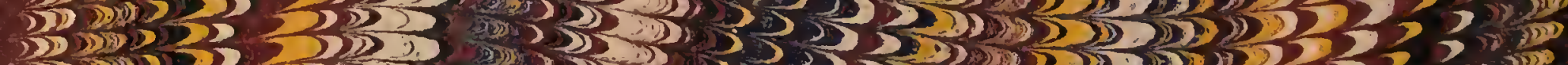

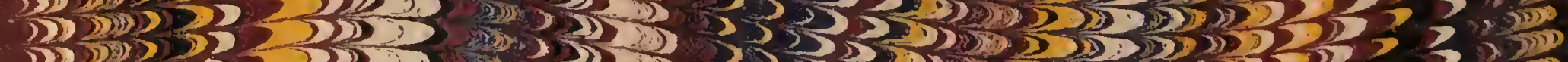

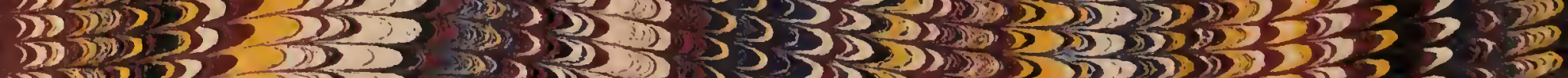

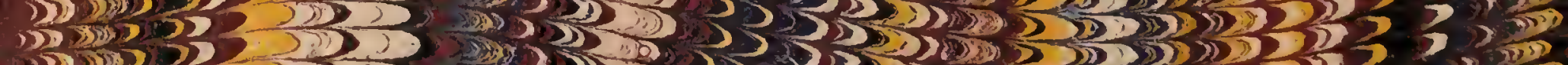

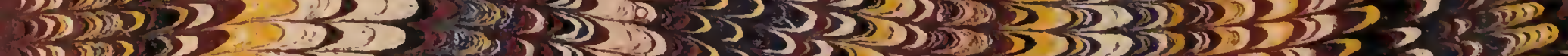

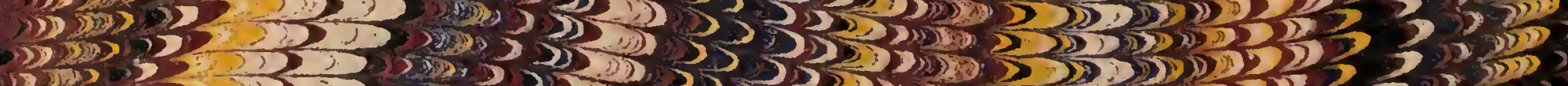

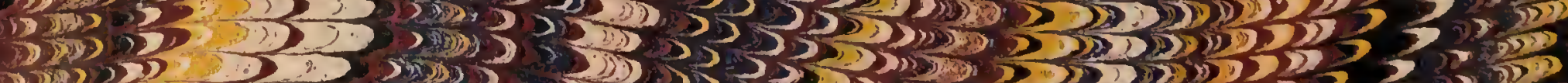

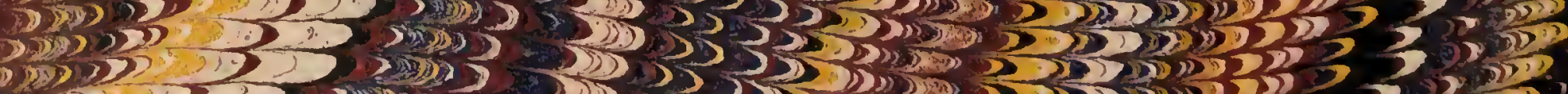

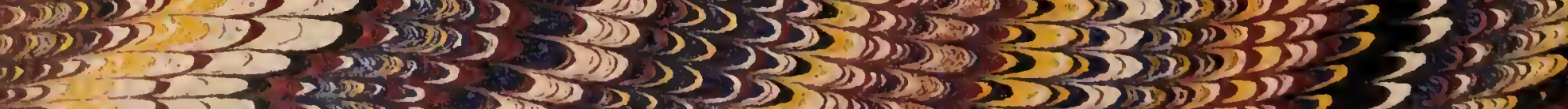

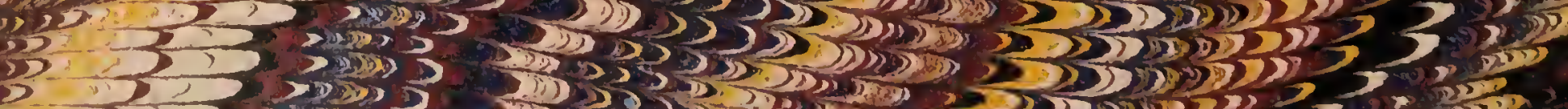

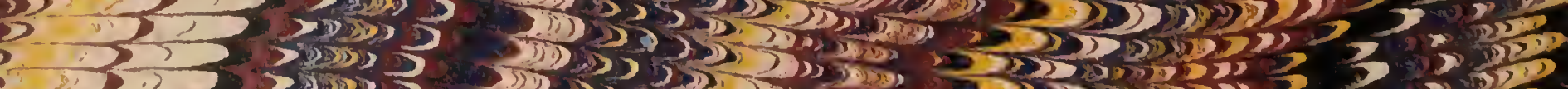

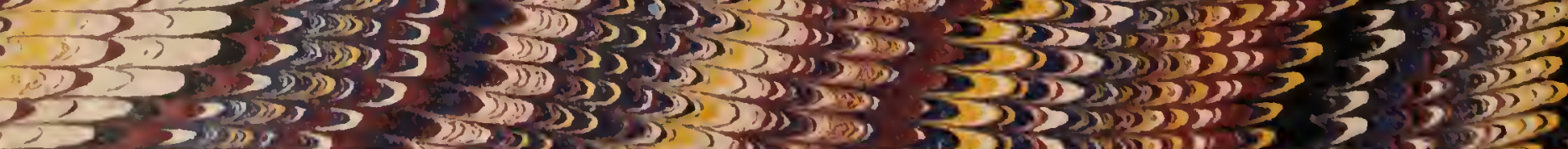
, 253

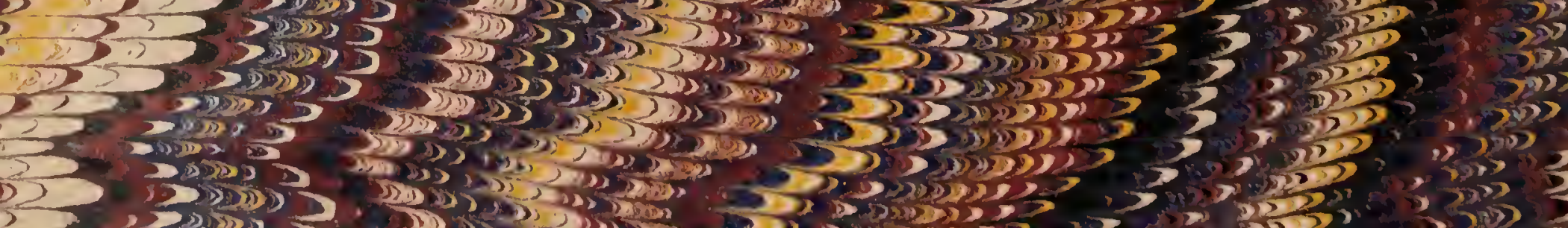




$$
19723 / \mathrm{B}
$$


12494 
Digitized by the Internet Archive in 2016 with funding from Wellcome Library 
\% A

$\begin{array}{lllllllll}P & R & I & N & C & I & P & I & A\end{array}$

$\begin{array}{llllllll}B & \mathrm{O} & \mathrm{T} & \mathrm{A} & \mathrm{N} & \mathrm{I} & \mathrm{C} & \mathrm{A} \text {. }\end{array}$

"स. 


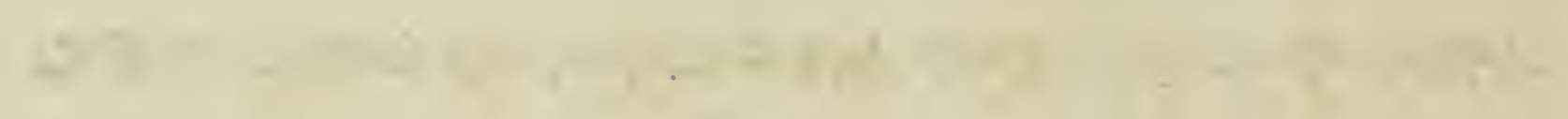

89919794

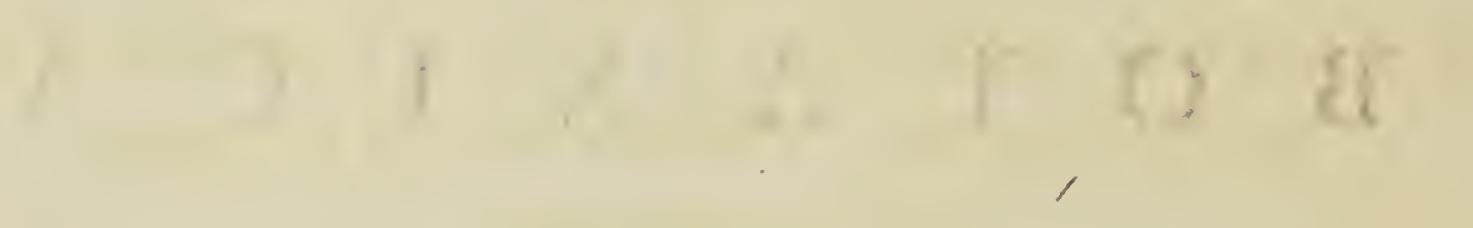




\title{
PRINCIPIA BOTANICA:
}

\author{
OR, A CONCISE AND
}

EASYINTRODUCTION

TO THE

\section{SEXUAL BOTANY \\ OF}

L I N N Æ U S.

WITH THE GENERA;

THEIR MODE OF GROWTH; (AS TREE, SHRUB, OR HERB;)

THE NUMBER OF SPECIES TO EACH GENUS;

WHERE PRINCIPALLY NATIVE;

A N D

THE NUMBER INDIGENOUS TO THE BRITISH ISLES:

ARRANGEDIN COLUMNSUNDER EACII CLASSANDORDER;

AND DIGESTED ALPHABETICALLY UNDER

SEVERAL GENERIC DISTINCTIONS.

By which Means most Plants may be thus far ascertained.

$$
T H R E L I N D E X E S \text { T. }
$$

1. Of the LinneAn Genera accented, with the Britisit NAMES.

II. Of such Trivial Names as were the Genera of Old AUthors.

III. Of the British Names, with the Linnean Genera; to which are added many of the SPECIFIC NAMES.

$$
\text { A.SO, }
$$

A Table of several VEGETABLE DRUGS not in the Indexes,

And he spake of trees, from the Cedar that growcth in Libanon, even unto the Hyfsop that springeth out of the wall.

I KINGS, IV. 33 .

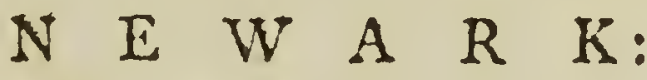

Printed by ALLiN and Co. and sold by G. G. J. and J. ROBswson, No. 25 , Pater-noster-Row, Lovnon, and all other Booksellers. 


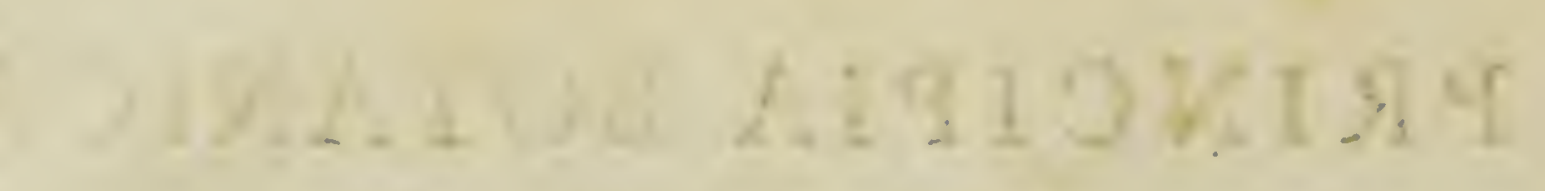

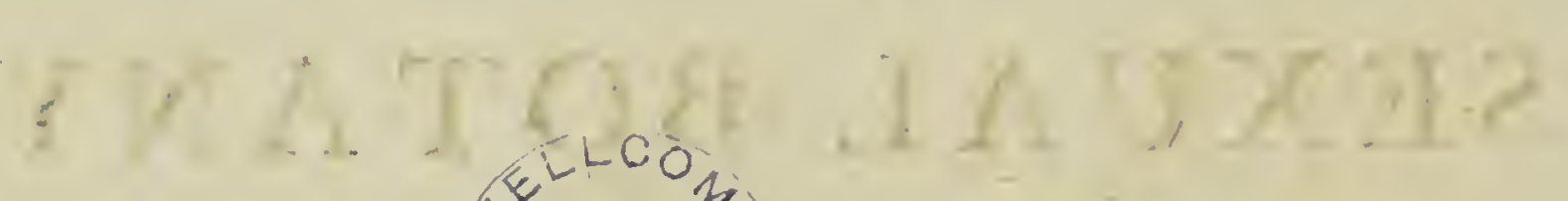

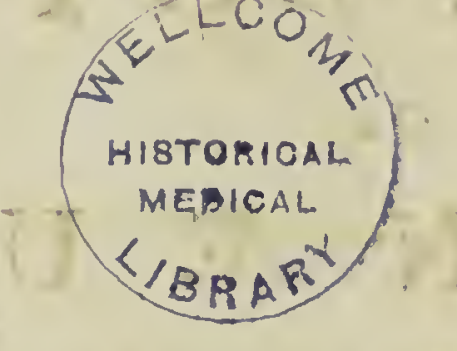




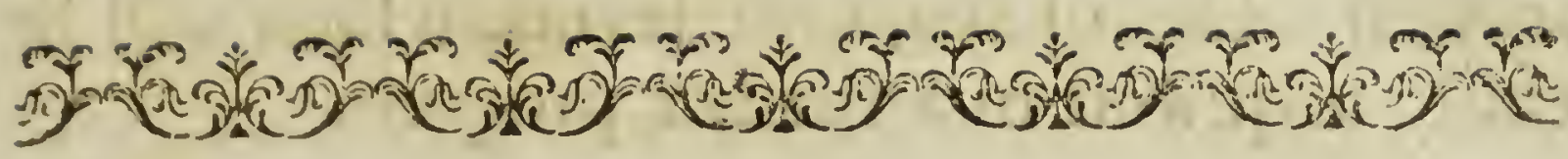 \\ $P \quad R \quad E \quad F \quad A \quad C \quad E$.}

$T^{T}$ may seem unnecefsary to attempt an in1 troduction to botany, after so laborious and established a performance as that of Mr. Lee; but as that work is very diffuse, and more proper for an adept in the science, than a young student; it was thought a more easy way of inculcating the first principles might be adopted on a lefs scale; and by confining the necefsary matter to each respective head, the whole might be so contracted, as to give a general idea of the system at one view; and the mind not left at large to expatiate over an unbounded prospect, which frequently creates confusion, and ends in disgust.

Another reason also occurred to render this attempt necefsary; that the price might be so low, as not to deter those in lefs affluent circumstances, from entering into the paths of nature; and therefore, the plates of the several parts of the fructification, the forms of the leaves, \&c. (which may be seen in every larger publication of botany) are omitted; as are also the 
several tables of scientific terms, which will be easily, acquired in a further progrefs.

By these means it is hoped to encourage a more extensive enquiry into the science; for nothing is more pleasing and instructive to the human mind, than to contemplate the harmony of creation, as nothing more strongly evinees the existence of a Supreme Cause.

It is impofsible for the most laboured harangues, or the most subtle reasoning, to make so deep and lasting imprefsions in the mind, as the works themselves; and no part of natural history is more inviting than the science of botany, as the objects of it continually surround us, and present themselves before our eyes; many of them indeed leave us in autumn, and go into winter quarters, but, like the parting of friends, the pleasure is enhanced by our meeting again in the ensuing spring: neither is any part of natural history more uscful for the most important purposes of life, as food, drink, raiment, $\mathcal{G}^{C} c$. and what is still more valuable, health; for it supplies us with a very efsential part of the Materia medica.

It is curious to observe the several ways nature hath chosen, for the protection of those plants she hath designed for particular purposes; some she hath armed with thorns or prickles, as a defence against the larger animals; others cmit a viscous matter to annoy the voracious insect; to others she hath given bitter, acrid, or narcotic juices; she hath 


$$
\text { P R E F A C E. }
$$

also given to many flowers aromatic and other efsential oils; all intended as weapons of defence against the depredations of a variety of animals, which would otherwise frustrate some higher intention.

Many of these plants, by the long experience of mankind, have already been converted into medicine, and other useful purposes; and by the diffusion of botanical science, it is hoped, in many others, the virtues which yet lie dormant will be awakened; and that those plants which are now ranked amongst destructive poisons, will gradually be reclaimed, and become a valuable acquisition to the science of medicine,

The analogy of plants as to their virtues, is well worth the enquiry of some able botanist, as the same virtues which are observed in a genus, do in a great measure run through all the species; and in some cases a whole order, and even a whole $\operatorname{claf} s$, will have the same predominant virtue.

It is hoped also some able enquirer into nature, will think it worthy attention to investigate the analogy and connection between vegetables and minerals; and whether there exists such a sensible analogy, that by inspecting the plants which grow naturally on the surface of any place, the quality of the soil may be discovered, as also the several sorts of minerals it may contain.

R. W. D. 


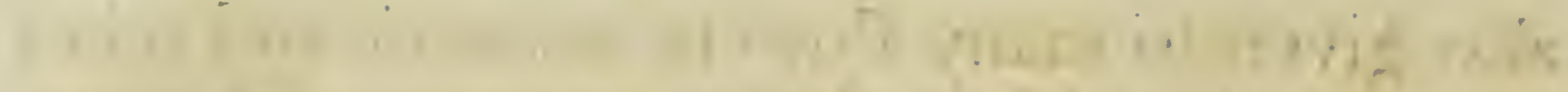

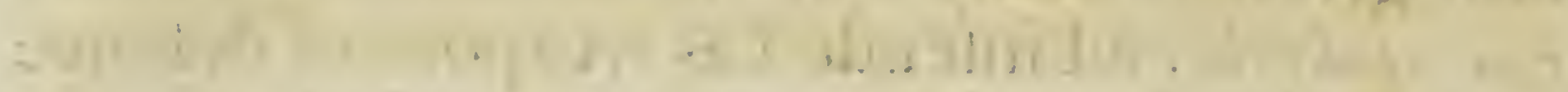

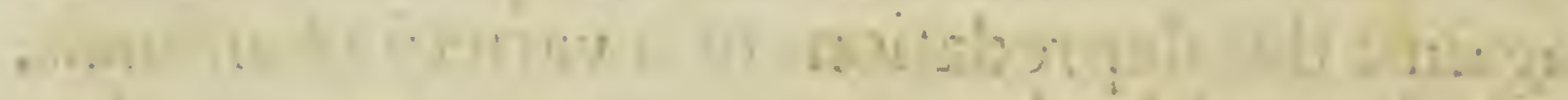

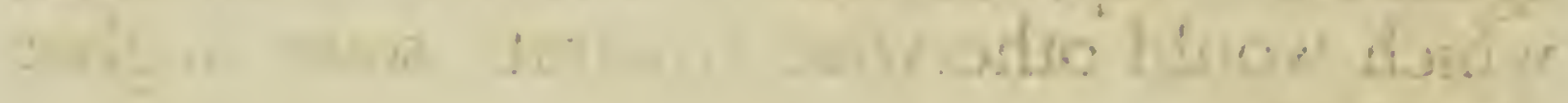
...tingin:

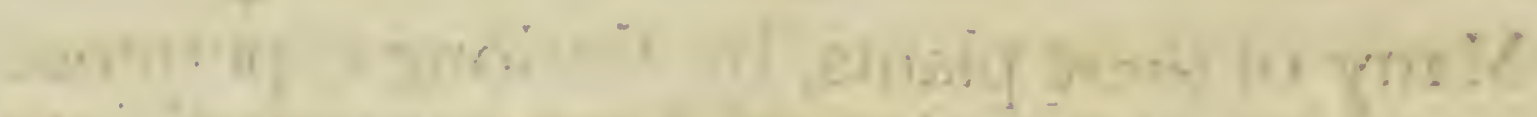

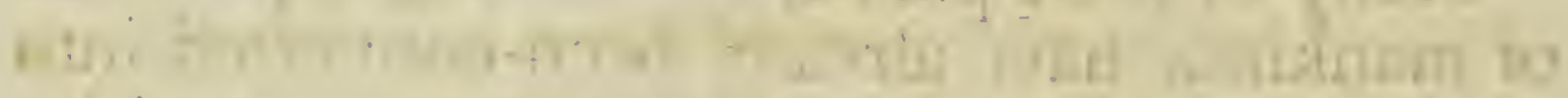

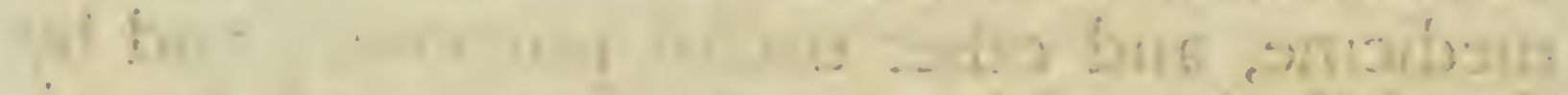

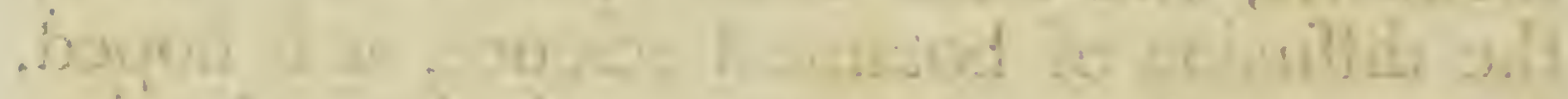

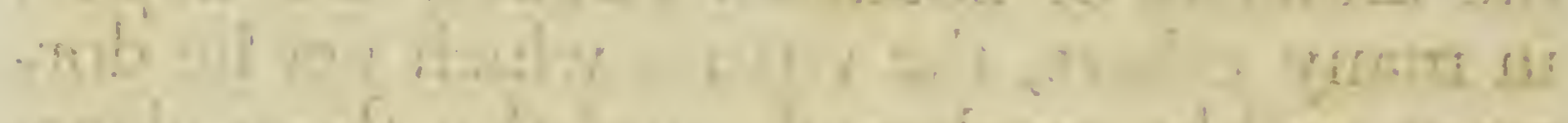

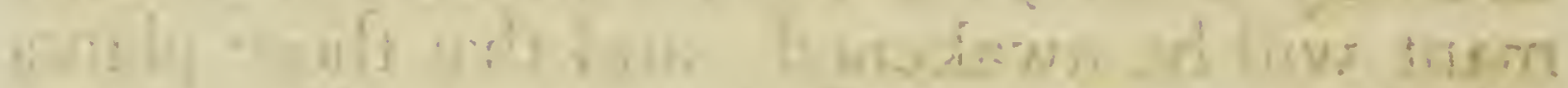

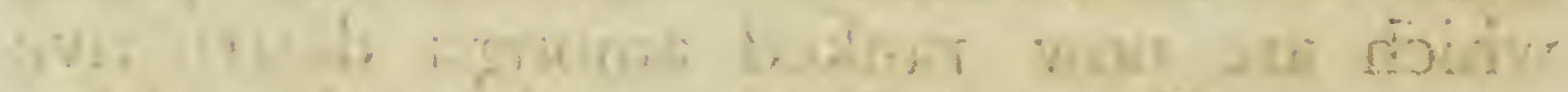

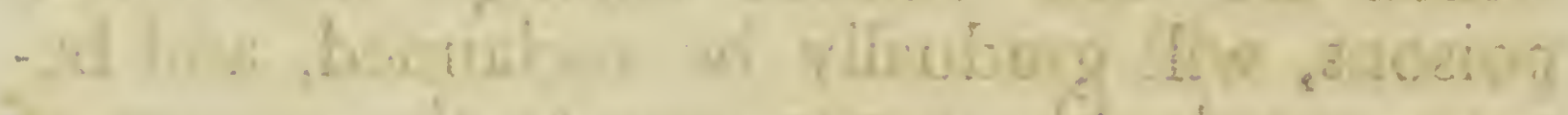

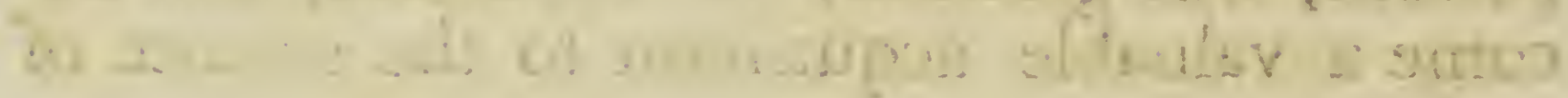
X.m.

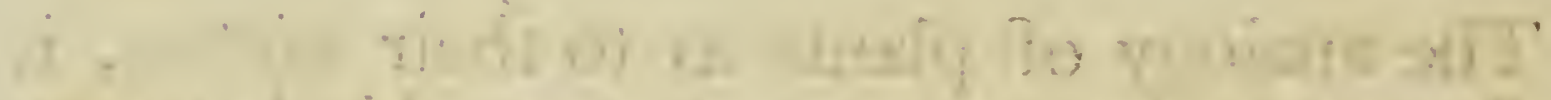

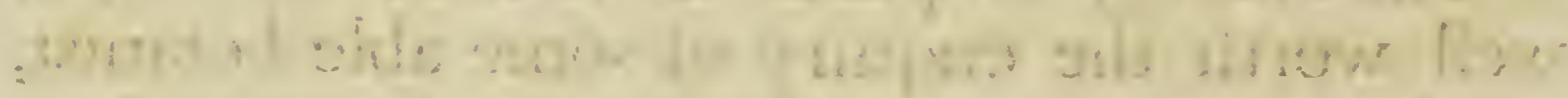

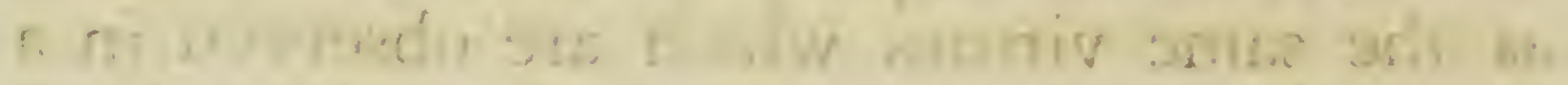

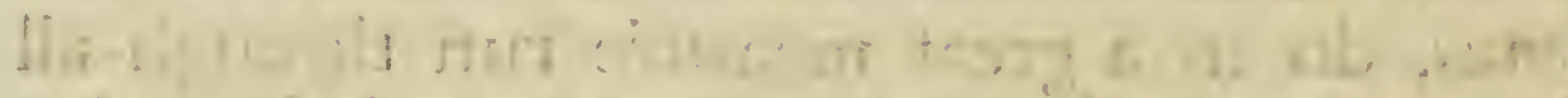

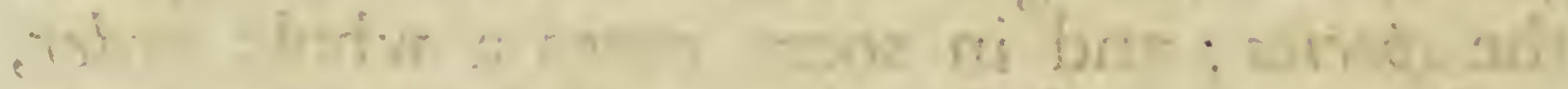

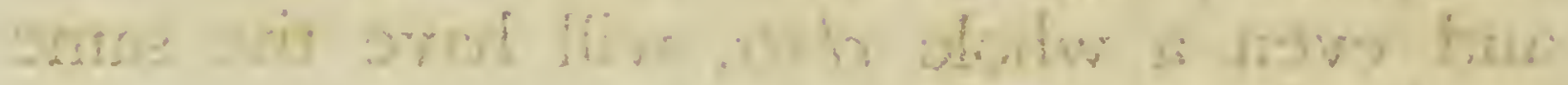

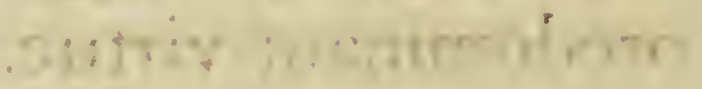

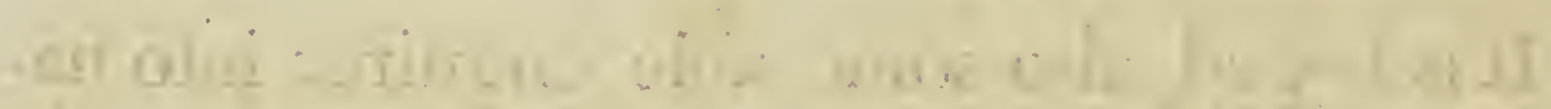
h.

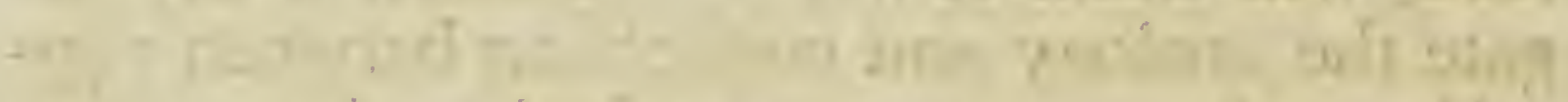

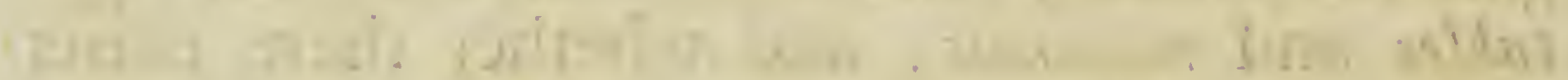

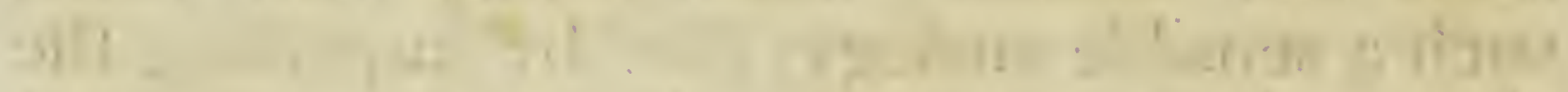

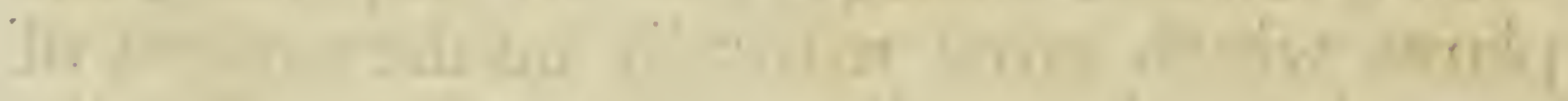

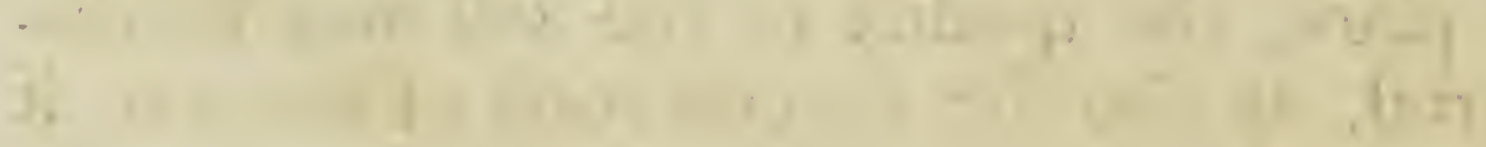
$[2+1+7$ 


\section{PRINCIPIA BOTANICA.}

O part of natural history hath employed the 4 3 pens of so many writers, as the science of $\mathrm{N}$ botany, in order to distinguish and methodize the great variety of plants.

The systems most in esteem for this purpose, before Linnceus, were those of Ray and Tournefort. Ray is said to have described 18655 species, including varieties; and his method or arrangement was founded upon the general habit or structure of plants, their growth, as trees, herbs, \&c. their greater or lefs degree of perfection, the number of petals, seed-leaves, and various other circumstances, which he arranged in 33 clafses.

Tournefort's method is chiefly founded upon the figure of the petals, which is preferable in that respect. to others, figure being more constant than number: His clafses are 22 , subdivided into 698 genera, which are again subdivided into 10146 species and varieties.

But the SEXUAL SYSTEM of Linnoeus hath now superseded all others, by its concise and elegant arrangement, and by shewing the great analogy and nice connection between plants and animals: It is founded on the difference in the sexes* of plants, and is divided into 24 clafses, which are subdivided into

several

* The Antients, as Theophrastus, Dioscorides, Aristotle, Heroditus, and Pliny, as well as the modern botanists, were well aware of the sexes in many plants, and thence concluded it might be the same in all; but the full inves. tigation, and clafsing them according to their sexes, was reserved for Linnzus. 
several orders, and under the orders are ranked the respective genera, + with their attendant species: The names of the clafses and orders are chiefly derived from the greek, those of the first 13 clafses being exprefsive of the number of stamina or males in a flower; and those of the orders, of the number of pistilla or females in a flower; and the names of the other cla.fses and orders, are also particularly exprefsive of the circumstances attending the males and females of the genera, under each respective clajs and order.

Therefore to investigate a plant, we must first find the clajs and order to which it belongs, $\oint$ for that is the grand foundation of the system; next we must find the distinction in that order; and then (by Linnæus's description) the gemus or family, $\|$ and afterwards the several species or relations; for the genera include a great number of relative species, distinguished by the specific difference of the root, the trunk, the branches, the leaves, $\mathcal{E}^{2} c$. (yet all agreeing in the efsential generic character) and are called by trivial names (exprefsive of the difference, or some other circumstances) added to the generic name.

The efsence of every vegetable, says Linnæus, consists in the fructification, (or mode of fruit-bearing) and the efsence of the fruetification consists in the flower and fruit: the efsence of the flower consists in the antherce and stigma, and the efsence of the fruit consists in the seed: Hence in his Serual.Theory, he necefsarily makes the

+ In thie 6th edit. of Linnaus's Genera Plantarum are described 1239 genera, which have since been augmented to 1444 . - See the Systema Vegetabilium, and the Supplementum Plantarum.

$\$$ The clafs and order of any plant may be found by the explanation of the ctatses and orders.

$\|$ The word genus, in natural history, is aptly compared to a family, with reference to some higher distinction; it is only an abstraet idea exprefsed by some general name oy term, comprehending a greater or lefs number of species or relations, resembling each other in cerrain established charaeter, or at least in the most efsential parts. 
the flower and fruit the foundation of his generic distinctions, and these are generally composed of seven parts.

1st, The CALYX. 2d, the COROLLA. 3 d, the STAMINA. $4^{\text {th, }}$ the PISTILLUM. $5^{\text {th, the }}$ PERICARPIUM. 6th, the SEMINA. 7 th, the RECEPTACULUM.

And the presence or absence, the number, figure, proportion, and situation of the several parts, constitute the gemus: but as there are few genera wherein all the parts of the natural character are constant in every one of the species; it is necefsary to fix upon such circumstances as are constant in both genus and species, and call those the efsential or ruling character; as well the more easily to distinguish one genus from another, as to regulate and fix the several species and their varieties, to their respective genera; for which purpose, in some cases, Linnæus was obliged to have recourse to the nectarium.*

The first four parts of the fructification are properly parts of the flower, and the last three are parts of the fruit.

I. The CALYX+ (a cup) is the termination of the $\mathrm{B} 2$

outer

* See nectarium explained under corolla: And see the Gen. Plantarum, and the Species Plantarum, with the Supplementum Plantarum, for a particular description of each genus and species, according to the natural character: And see the Systema Vegetabilium, where the genera and species are discriminated according to their efsential and specific differences; under several generic and specific distinctions.

+ The calyx is considered a part of the flower, though it more generally attends, and is permanent with the fruit; as in the clafs didynamia, and most other plants; yet sometimes it drops before or with the corolla, and before the fruit is ripe; as in the clafs tetradynamia, and many other plants. It is also considered a part of the flower, as there is no instance of its coming out after the plant hath done flowering; yet in patagonula it is observed to grow to a much larger size in the fruit, than it had in the flower: In some plants there is none, or scarce perceptable; in others it is only a rim or border (margo). The germen is also considered as part of the flower, as being the base of the pistillum, though it afterwards becomes the seed-iefseld 
outer bark (cortex) of a plant, and its chicf use is to inclose, support, and protect the other parts of the fructification; when present, it is seated on the receptacle, and is distinguished by its figure, and by the number, division, and shape of its leaves or segments; and by the following names, according to the circumstances with which it is attended.

1st. PERIANTHIUM, (surrounding the flower) when its station is close to, and surrounds the other parts of the fructification, and it is then called the perianthium of the fructification: If it includes many florets, as in scabiosa, and other aggregate and compound flowers, it is called a common perianthium; if it includes only one floret, in such flowers, it is called a proper perianthium; if it includes the stamina, and not the germen,, it is the perianthium of the flower, and is said to be above, as in lonicera, ribes, campanula, $\mathcal{E}^{2} c$.; if it includes the germen, but not the stamina, it is the perianthium of the fruit, and is said to be below, as in linnea and morina, each of which have two calyxes and two receptacles above each other, one of the flower and the other of the fruit: and may therefore serve as instances in both cases.*

2d. INVOLUCRUM (a cover) when stationed at the foot of an umbel, below the common receptacle, and at a distance from the flower; and it is called universal, if placed under the universal umbel; and partial, if placed under a partial umbel.t

3d. AMEN TUM (a thong, meaning a catkin) when it consists of a great number of chaffy scales, disposed along a slender axis or common receptacle, which from

S See germen under pistillum

* When the calyx is a perianthium, it generally corresponds with the petals of the corolla, as to the number of its leaves.

+ See umbellate flowers under distinction of flowering.

In umbellate flowers, several want both the universal and partial iniolue crum; as parsnep, herb-gerard, burnet-saxifrage, dill, $\mathcal{C}_{\text {. }}$; and some have only a partial involucrum, as shejherd's-ncedle, chervil, mastcr-wort, Bic. 


\section{B O T A N I C A.}

its resemblance to a cat's tail, hath obtained the name catkin: and these flowers have generally no petals: Sometimes the same amentum supports both male and female flowers, distinct, on the same plant, as in carpimus, $\mathcal{J}_{\mathrm{c} .}$; sometimes the male and female flowers are removed from each other on the same plant, and the amentum supports only the male flowers, and the female flowers are inclosed by a perianthium, as in corylus, juglans, fagus, छ $\mathcal{C}_{\text {. }}$; and sometimes an amentum only supports male flowers on one plant, and female flowers on another plant, as salix, populus, E̋c.

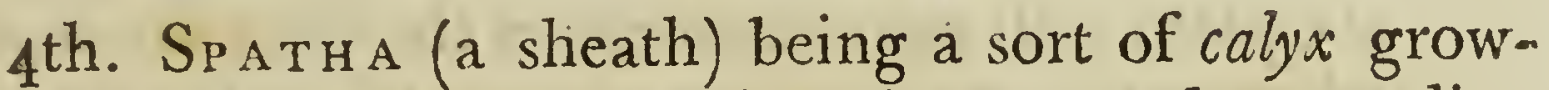
ing from the stalk, bursting lengthways, and protruding a spadix, $\$$ (or receptacle) supporting one or more flowers, which have often no perianthium; and consists either of one leaf, with a valve or opening on one side only, as in narcifsus, galanthus, and the greater number of spathaceous plants; or of two leaves, with two valves or openings, as in stratiotes, ECc.; or is imbricated, as in musa, $\mathcal{E}^{2} c$. with one or two valves.

5th. GLUMA, (a husk) this chiefly belongs to corn and grafses, consisting of one, two, three, or more valves, folding over each other like scales, and freqnently terminated by a long, stiff, pointed prickle, called the arista (beard or awn).

6th. Calyptra, (a veil or covering) the proper calyx to mofses; it is placed over the antherce of the stamina, resembling an extinguisher, a hood, or monk's cowl.

$7_{\text {th. VOLVA, }}^{*}$ (from its infolding or involving) the proper

$\$$ See spadix under receptaculum.

* Volva, though mentioned as a calyx to fungusses, yet in the Genera Plantarum, it is not once taken notice of in the description of those genera. In Dr. Alston's Tyrocinium Botanicum, published at Edinburg in 1753, are enumerated the several calyxes of each sort, from a former edit. of the Gen. $P l$ then containing 1021 genera; 673 of which have a perianthium; 75 an 
proper calyx to fungufses, being membranaceous, and surrounding the stalk or pillar before therr expansion.

N. B. It is often difficult to distinguish the calyx from the bractea, (floral leaves) which are found on many plants, situated on the flower stalks; and are often so near to the lower parts of the fructification, as to be confounded with, and mistaken for the calyx, as in tilia, helleborus, pafsiflora, Ėc.; (in helleborus the calyx is wanting) but they may be best distinguished by this rule; the floral leaves differ in shape and colour from the other leaves of the plant, but are commonly of the same duration; whereas the calyx always withers when the fruit is ripe, if not before.

See bractece, under Props.

II. The COROLLA (a wreath or little crown) is the termination of the inner bark (liber) of the plant; which accompanies the fructification, in the form of leaves variously colored: it is generally seated on the receptacle, sometimes on the calyx, serving as an inner work of defence to the part it incloses; as the calyx, which is usually of stronger texture, does for an outer work. The leaves of which the corolla are composed are called petals, by the number, division, and shape of which it is distinguished; and the corolla is said to be below, when it includes the germen, and is attached to the part immediately below it, as in salvia, borago, convolvulus, primula, Ec.; and it is said to be above, when it is placed above the germen, as in lonicera, ribes, cratergus, E⿱乛龰c. In respect to duration, the corolla either continues till the fruit is ripe, as in nymphcea; or falls off

incolucrum; 18 an amentum; 70 a spatha; 99 a glama; 3 a calyptra; 25 have both a perianthium and iuvolucrum; and a few have both perianthium, and spatha. In eriophorum, xyris, cyperus, and scirpus, the spike is the calyx; in morinda and cringizm, the common receptacle is the calyx, and about 110 have no salyx, or very imperfect. 
at the frrst opening of the flower, as in actea, thatidtrum, or falls off with the stamina, and other parts of the flower, as in most plants; or does not fall, but withers, as in campanula, cucumis, and others.

There is also a part which Linnæus says, principally belongs to the corolla, as an appendage to the petals; which he calls the NECTARIUM,* (from nectar, the fabled drink of the Gods) and is that part containing the honey, which is the principle food of bees and other insects; but, though in such plants where it is found, it may more commonly be attached to the corol$l a$, and be then most evident; yet it is almost as oft attached to other parts of the frictification: Linnæus therefore chiefly makes use of it, as an efsential character in many of the genera, as being lefs variable than his other distinctions; and observes that when it is distinct from the petals, (that is) not united with their substance, those plants are generally poisonous: The tube or lower part of flowers of one petal, he considers as a true nectarium, because it contains a sweet liquor. But as it affords very singular varieties in other instan. ccs, it hath obtained the following distinctions.

1st. Calycine nectaria, such as are situated upon, and make a part of the calyx, as in tropcelum, mono. tropa, $\varepsilon^{3} c$.

2d. Corollaceous NeCTARia, such as are attached to the corolla; and are called calcariate (from calcar) when they resemble a spur or horn; which are either on flowers of one petal, as in valeriana, antirrhinum, Ec. or on flowers of many petals, as in orchis, Delphinium, viola, fumaria, E3c.: Or the nettarium lies with-

in

* The proper use of the nectarium, and why it should have such very dif. ferent situations, is not yet known: but as it is found in most plants, there it great reason to believe it an efsential part in the fructification, though not always perceptible. 
in the substance of the petals, as in fritillaria, lilium, berberis, iris, ranunculus, \& $\mathcal{J}^{2}$.

3d. Stamineous nectaria, such as attend the stamina, and are either seated upon the antherce, as in adenanthera: or upon the filaments, as in laurus, dictamnus, campanula, $\mathcal{E} c$.

4th. Pistillaceous nectaria, such as accompany the pistillum, and are placed upon the germen, as in hyacinthus butomus, cheiranthus, hesperis, EC.

5th. Receptaculaceous NeCtaria, such as join to the receptacle, as in polygonum, sedum, sempervivum, छ'c.

6th. Nectaria that crown the corolla, that is, when placed in a series or row within the petals, though entirely unconnected with their substance, as in pafsiflora, lychnis, silene, ESc.; and in this situation it often resembles a cup, as in narcifsus, E 3 .

7 th. Nectaria of singular construction, being such as cannot properly be placed under any of the foregoing distinctions, as in amomum, curcuma, salix, urtica, $\mathcal{E} c$.

III. The STAMINA. (threads or chives) These are the males of the flower, proceeding from the wood of the plant, each stamen consisting of two parts, (viz.) the filament and the anthera; and in most flowers are placed upon the receptacle, within the corolla, and round the germen; and are chiefly distinguished by number.

The FILAMENT (from filam, a thread) is the threadshaped part of the stamen, serving as a footstalk to elevate the antherce, and is sometimes found to have jags or divisions, (lacinix) which are either two, as in salvia; three, as in fumaria: or nine, as in the clafs diadelphia. They are also distinguished by their form or figure, as awl-shaped, thread-shaped, hair-like, spiral, revolute, E. . : also by their proportion, as equal, unequal, irregu. lar. 
lar, long, or short; atso by their sination, being generally opposite to the leaves or divisions of the calyx, and alternate with the petals; that is, when the divisions of the calyx are equal in number to the petals, and to the stamina.* In flowers of one petal (monopetalous) they are generally inserted into the corolla: but scarcely ever in flowers of more than one petal, (poly petalous) but into the receptacle. Yet in the clafs icosandria, they are inserted into the calyx or corolla, (though the flowers have many petals) as also in a few other plants. But in the clafs polyandria, and most other plants of many petals, they are inserted into the receptacle, like the calyix and corolla. But the clafs gynandric is an exception to the above rules, where the stamina are placed upon the pistillum, or female part of the flower; and are sometimes without filaments.

The Anturra, (from anthos, a flower) emphatically so called, from its great utility in the fructification, is the top or summit of the filament, containing the impregnating pollen or farina; t and is either one to each filament, as in most plants; or one common to three filaments, as in cucurbita, $\mathcal{S}^{3} \mathrm{c}$.; or one common to five filaments, as in the whole clafs syngenesia; or sometimes there are two anthera to each filament, as in ranunculhs and mercurialis; three to each filament, as in fumiaria; five to three filaments, as in bryonia; or five to each filament, as in theobroma. The anthera is also distinguished by its form or figure, as oblong, round, angular, EC. It also consists of one or more cells, which burst differently in different plants; either on the side, as in most C plants;

* By this rule it may generally be known whether calyx or corolla be wanting, when their is a deficiency in either.-As soon as the stamina have performed the office afsigned by nature, they wither and drop off.

t The-particles of the pollen or farina, appear by glafses to be of very different forms. - The pollen makes a third division of the stamen, but Linnxus generally includes it in the term anthere, along with the little cells in which it is inclased. 
plants; on the top; or from the top to the base. It is also fastened to the top of the filament, cither by its base, as in most plants; or horizontally, by its middle, to the top of the flament, so poised as to turn like a fane (versatilis); or it is fixed by its side, leaning to the top of the filament, then called incumbent; or it sometimes grows to the nectarium, as in costus; to the recepiacle, as in arum; to the pistillum, as in the clafs gynandria.

IV. The PISTILLUM. (a pestle) This is the female of the flower, proceeding from the pith of the plant; and is that erect column, which is generally placed in the center of the flower, amidst the stamina; and consists of three parts, the germen, the style, and the stigma.

The GERMEN (a bud) is the base of the pistillnm. supnorting the style, and, after a procefs of nature, becomes a seed-vefsel; may therefore be considered as the rudiment of the pericarpium; and is distinguished by its shape, number, and situation: and is said to be above or below, according to its situation above or below the attachment of the corolla.

The STYLE (from stylus, a pillar) is that partwhich elevates the stigma from the germen, in order to receive the influence of the stamina, and to convey the effects down to the germen, as through a tube. It is distinguished either by its number, * which, when present, (or

when

* The number of styles, generally speaking, is equal to the number of germina, each germen having its own proper style. The compound flowers, in the clals syngenesia; the cone-bearing plants; rose, ranunculus, and many others, shew this to be the natural structure: yet several plants have more than one style to a single germen, as in the umbeliiferous plants (pentan. digyn.) and many others. Some have only one style common to many germens, as the rough-leazed plants (pentan. mono.) and most of the lip flowers. (didyna. gymnos.) Again, there are some plants which seem to form a medium between the two latter, the style being single at its base, but afterwarcis branching out into as many ramifications as there are divisions or cells in the seed-aefsel, as in geranizm, and malloru, also in hiviscus, and some others. 
when absent, the number of stigmata) gives rise to most of the orders, and are called so many females; or by its divisions (lacinix) being double, treble, or quadruple, E'c. though joined at the base; or by its length, being longer, shorter, or equal with the stamina; or by its proportion, being thicker or thinner than the stamina; or by its foure, being angular, cylindric, awl-shaped, bent, Eंc. : or by its situation, being generally on the top of the germen, though in some instances supposed to be both above and below, as in capparis and euphorbia; unlefs the lower part in these genera be considered as the extention of the receptacle: It is also often placed on the side of the germen, as in hirtella, suriana, also in rosa, rubus, and the rest of the plants in the clafs and order icosandria polygynia. With respect to duration, it generally falls with the other parts of the flower; but in some plants is permanent, and attends the fruit to its maturity, as in the clafs tetradynamia. In flowers which have no style, the stigma adheres to the germien.

The STIGma, (a mark) when single, is generally placed like a head on the summit of the style; when several, they are either placed on the top, or regularly disposed along the side; and covered with a moisture, to retain the pollen of the anthera. It is distinguished either by its number, being single in most plants; by its divisions; by its figure or shape; by its length; by its thicknefs; and by its duration, as in most plants it withers when the germen is become a seed-vefsel; in some it is permanent, as in papaver.

V. The PERICARPIUM (round the fruit) is the germen grown to maturity, and now become a matrix or seed-vefsel; yet however all plants are not fur nished with a seed-vefsel, as in corylus, EC. and in many it is supplied chiefly by the calyx, which converging, incloseth the seeds till they arrive at maturity; as is the case with the rough-leaved plants, the lip, and compound

flowers 
Aowers of the several clafses, pentandria, didynamia, and syngenesia: Sometimes the receptacle supplies the office of seed-vefsel, as in gundelia; and sometimes the nectarium, as in carex. The pericarpium is situated at the receptacle of the flower, either above or below, or both, as in saxifraga and lobelia: and is distinguished by the following appellations, according to its different structure.

1st. CApsula, (a little chest or casket) which is frequently succulent whilst green, but when ripe, is a dry husky seed-vefsel, that cleaves or parts in some determinate manner, to discharge its contents; and by some sort of elactic motion, the seeds are often darted forth with considerable velocity, as in dittamnus, E'c. It opens also various ways, either at the top, as in most plants; at the bottom; at the side; horizontally acrofs the middle; or longitudinally; and if it is articulated or jointed, it opens at each of the joints, which contains a single seed. It is further distinguished ex. ternally, by its number of values ${ }^{*}$ and internally, by the number of its cells or divisions wherein the seed is inclosed; as also by its shape and substance.

2d. Siliqua (a pod) is a pericarpium of two valves; but as some are long, others round or broad, Linnacus thought it necefsary to distinguish them by their form, into siliqua and silicula; which gives rise to the two orders in the clafs tetradynamia: The siliqua means a long pod, being much longer than broad, as in brafsica, sinapis, $\mathcal{E}^{3} \mathrm{c}$; the silicula (a little siliqua) is a roundish pod, either flat, or spherical, and the length and breadth nearly

* Capsules and dry pods are divided externally into one or more pieces, called by Linnaus walves; and internally are generally divided by membranous partitions (called difsepiments) into cells, sometimes longitudinally, as in cheiranthus; lunaria, $\mathcal{E}_{0}$; and sometimes transversly, as in jointed pods. 
nearly equal, as in hunaria, draba, thlaspi, Eco. in both, the apex, which had been the style, is often so long beyond the valves, as to be of equal length with the pod; and the seeds in both are fastened alternately by a slender thread, to both the sutures or joinings of the valves.

3d. LEGUME (pulse) is also a pod, and is likewise a pericarpinm of two valves, wherein the seeds are fastened to short receptacles along the upper suture only, on each side, alternate: this chiefly belongs to the papilinaceous (butterfly) flowcrs of the clafs diadelphia.

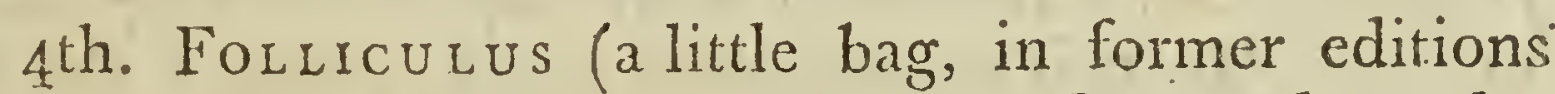
called conceptaculum) is a pericarpium of one valve only, opening lengthways on one side, and the seeds not fastened to the suture, but to a receptacle within the fruit, as in apocynum, asclebias, $E^{3} C_{\text {. }}$.

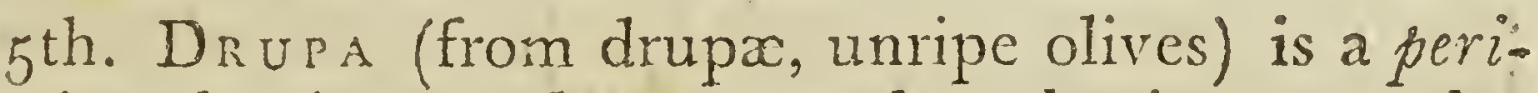
carpium that is succulent, or pulpy, having no valve or external opening, and contains within its substance a stone or nut; that is, a seed inclosed with an hard ligneous crust, as olea, cornus, juglans, prunus, amygdalus, E3c.; and when the drupa is seated below the calyx, it is furnished with an umbilicus like the pomum.

6th. Ponum (an apple) is also a pericarpium that is succulent or pulpy, and without valve; but containing in the middle a membranous capsule, with several cells or cavities, containing the seeds; and at the end opposite the footstalk, is generally a small cavity called umbilicus, (the navel) from its resemblance to that part in animals, and which was formerly the calyx, seated an bove the fruit, and permanent, as in pyrus, cucumis, cucurbita, $\Xi$ c.

7th. BACCA (a berry) is also a pulpy pericarpium without valve, inclosing one or more seeds, which have no membranous capsule or covering, but are disposed 
promiscously through the pulp, * as in solanum, EF. and are generally placed on footstalks, attached to receptacles within the pulp, as in ribes, EJc. The berry also admits of the following distinetion; it is said to be proper, when it is a true pericarpinin formed of a germen: and improper, when it is formed from other parts of the fructification; as in morus, rosa, juniper, taxus, Ėc. a large succulent calyx becomes a berry'; and in juniper the threepetals become the umbilicus; in poteriaim the berry is formed of the tube of the corolla; in fragaria, Ec. it is formed of the top of the receptacle: in rubus, $\mathcal{E}_{c} c$ it is formed from a seed, which is the receptacle of the berry; in ruscus, E3c. it is inclosed with. in, and is a part of the nectary. The berry is commonly either round or oval, and is frequently furnished with an umbilicus, as in ribes, E.c.: It doth not naturally open to disperse the seeds like the capsule, that office being performed by birds and other animals.

8 th. STROBilust (the pine tree, a cone) is a pericarpium formed of an amentum, being a seed-vefsel composed of woody scales placed against each other in the form of a cone, opening only at the top of the scales, being firmly fixed below to a sort of axis or receptacle. occupying

* If Linnzus had more closely adhered to his difinitions, it would have made the science more intelligible and lefs confused; for the pericarpium in capsicum is called a berry, yet hath no pulp, and is hollow within; also in xanthium it is called a berry, though it contains a nut in a dry pericarpium : neither is drupa always succulent or pulpy, though so defned, as in ulmus, pistacia, sparganium, $\mathcal{E}^{2}$; neither is the seed always a stone or nut, as in almus, schrebera, $B$ c.

+ Though Linnaus calls strobilus a pericarpium, yet in his Gen. Pi. he ather makes use of it as a calyx in the cone-bearing genera; which in his Fragments of a Natural Meihod, under the order conifera, amount to seven. (viz.) cupressus, ephedra, equisetum, juniperus, pinus, taxis, and thuya: In which, as the seeds are attached together in the form of a cone, so the plants themselves grow conically, and make a beautiful appearance. See the clats. es monoccia, dioecia, and cryptogamia. 
occupying the middle of the cone, as in pinus, thuya, cuprefsus, \&zc.

VI. The SEMINA.* (secds) A seed is the efsence of the fruit of every vegetable, and is defined by Linnæus to be a deciduous part of the plant, containing the rudiments of a new vegetable, fertilized by the sprinkling of the pollen; and they are distinguished according to number, shape, texture, appendage, \&c. A seed, properly so called, consists of the five following parts; to which is added the nut and propago.

1st. The Corculum (from cor, a heart) is the essence of the seed, and principle of the future plant; and consists of two parts, (viz.) plumula and rostellum. Plumula (a little feather). is the scaly part and efsence of the corculum, which ascends and becomes the stem or trunk of the plant: it extends itself into the cavity of the lobes or cotyledons, and is terminated by a small sort of branch resembling a feather.-Rostellum (a little beak) is the plain or simple part of the corculum, which descends into the earth, and becomes the root: its form is that of a small beak, placed without the lobes, and adhering internally to the plimula.

2d. The Cotyledons (from cotyledon, the hollow of the hucklebone) are the thick porous side-lobes of

the

* Plants, in analogy to animals, may properly be said to be viviparous and cviparous; seeds are vegetable eggs, and buds the living foctufses or infant plants; some also are only viviparous, others only oviparous.-The focundity of some plants is wonderful. Dr. Milne says, from a single plant or stalk of Indian Turky wheat, are produced in one summer 2000 seeds; in clecampane, 3000 ; of sunflower, 4000 ; of poppy, 32000 ; of a spike of cat's :ail, 10000 and upwards; a single fruit or seed-vefsel of tobacco contains 1000 seeds, that of white poppy 8000 . Mr. Ray relates from experiments, that 1012 tobacco seeds are equal to one grain, and consequently those of the whole plant, in that proportion, amounted to 36000 : he also estimates the annual produce of a single stalk of spleen-esort to be upwards of one mi:lion of seeds. 
the seed, consisting of farinaceous matter, and which involve, and for sometime furnish nourishment to the embryo plant; but when it becomes strong, they wither and die away.* The cotyledons are also called the seminal or seed-leaves; some plants have only one, $t$ as in grafses and in cuiscuta, EJc.; others two, ás in vicia, Ec.; linum hath four: cyprefsus hath five; and pinus, Linnæus sáith, hath ten. The cotylidons in mushrooms, ferns, and mofses, are not sufficiently ascertained, to know if they have any.

3 d. The Hrium (the black spot on a bean, called the eye) is the external mark or scar on the seed, where it was fastened within the pericarpium.

4th. The Arillus, a term used by Linnæus, to exprefs the proper exterior coat or covering of the seed; which falls off spontaneously, and is either cartilaginus or succulent; yet seeds are said to be naked, when not inclosed in any sort of pericarpium, as in the clafs and order didynamia gymnospermia.

5th. The Coronula, (a little crown) which is either a little sort of calyx, (calyculus) adhering to the top of the seed, like a little crown, and afsisting to disperse it by flying, as in scabiosa, knautia, Ėc. where the little calyx of the floret becomes the crown of the seed.

* If a plant be cut below the cotyledons, it will scarce ever put out fresh leaves, but withers and decays; if it is cut above the cotyledons, ir generally shoots out afresh, and continues to grow: Therefore, if plants, whose coty= ledons rise above grnund, as turneps, $\mathcal{S}_{c}$. be cut, or eat to the ground by catile, they decay; but where the cotyledons remain below ground, as in grafse es, and are cut or eat to the ground, they will shoot out afresh.

+ Linnzus observes that those plants which are said to have only onecotye bedon, may more properly be said to want them; as they remain within the seed.-Two cotyledons are most common, and those plants that are thought to have more, are in fafe said to be only different divisions almost to the base. 


\section{BO TA N I C A.}

seed. Or the coromila is a down (pappus) which is either feathery, as in valeriana, leontodon, gnaphalizm, Éc. or it is hairy, as in tufsilago, senecio, hieracium, E ${ }^{2} . ;$ it is also either sitting, (sefsilis) that is, attached close to the seed, as in hieracium, Ec. or footstalked (stipitatus) by a thread, elevating and connecting the crown or tuft with the seed, as in lactuca, crepis, E'c. Some seeds are also furnished with a wing, a tail, a hook, an auin, E3c. all coming under the term coromula, and tending either to disperse or fix the several seeds to which they belong.t

6th. Nux, (a nut) which is a seed inclosed in an hard woody substance, called the shell, which is one-celled, two-celled, $83 c$. and the inclosed seed is called (nucleus) the kernel.

The seed of a mofs, not coming under the above description, Linnaus calls PROPAGO, (a slip or shoot) which hath neither coat nor cotyledon, but consists only of a naked plumula, where the rostellum is inserted into the calys of the plant.

VII. The RECEPTACULUM (receptacle) is the base which receives, supports, and connects the other parts of the fructification, but it is only mentioned by Linnæus (in his Gen. Pl.) when it can be introduced as a character varying in shape and surface, as principal1)

* The down with which many seeds are furnished, as in goat's-beard, dandelion, thistle, $\mathcal{E}_{C} \mathrm{c}$. hath generally been thought intended to disperse them: yet as the down frequently breaks off, when the seeds have flown to some distance, and is seen flying alone; it hath been imagined by some, that the down is only intended as a defence of the seed till arrived at maturity.

+ Some seeds are also furnished with an elastic force, in order to disperse them, which is either in the calyx, as in oats, and some others; in the pappus, as in centaurea-crupina; or in the capsule, as in geranium, fraxinella, spuring cucumber, EC. Other seeds, especially thofe whose pericarpium is a berry, as also the nutmeg, and other nuts, are dispersed by birds and other enimals. 
ly in the clafs syngenesia. It hath the following distinctions.

1st. A Proper Receptacle, when it supports the parts of a single fructification only; and when it is a base to which only the parts of the flower are joined, and not the germen, it is called a receptacle of the flower: in which case, the germen being placed below the receptacle of the flower, hath a proper base of its own, which is called the receptacle of the fruit: and it is called a receptacle of the seeds, when it is a base to which the seeds are fastened within the pericarpium (see bacca;) in some simple flowers, where the germen is placed above the receptacle of the flower, the fruit hath a separate receptacle, as in magnolia, uvaria, Eंc. in which genera the numerous germens are seated upon a receptacle, rising like a pillar above the receptacle of the fruetification.

2d. A Coman Receptache, called so because it supports and connects a head of flowers in common, as in the amentum, and other aggregate flowers.

3d. Umberla, (an umbel) which Linnaus calls a receptacle.-See aggregate flowers.

4th. Cyma (a sprout) is also called a receptacle.See aggregate flowers.

5 th. Racmis, (the back bone) a thread-form receptacle, collekting the florets longitudinally into a spike, in many of the glumose flowers, as wheat, barley, rye, E'c.

6th. SPADIX (a branch of the palm) antiently only signified the receptacle of a palm (phcenix) ifsuing out of a spatha, and branched: but now every flower-stalk that is protruded from a calyx called spatha, is called a spadix, as in narcifsus, E3c.-See aggregate flowers. 


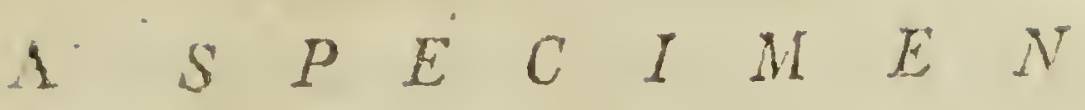

O F T II E

\section{DESCRIPTION OF A PLANT,}

According to the natural Charadter, from the Genera Plantarum; and also the efsential Charaiter of the same Plant, with the several Species, from the Systema Vegetabilium.

$$
\begin{gathered}
P A \underset{\text { P A V }}{\text { P }} \text { E R. } \\
\text { Natural Character. }
\end{gathered}
$$

Caly:x. Aperianth, two-leaved, egg'd, end-nick'd; leaflets rather egg'd, concave, obtuse, deciduous

Corolla. Petals four, roundish, flat, cxpanding, large, narrower at the base, lefs alternately.

Stamina. Filaments numerous, capillary, much shorter than the corol.; anthers oblong, comprefs'd, erect, obtuse.

Pistillum. Germ. roundish, large; slyle none; stigma targetted, flat, radiated.

Pericarpium. A capsule crown'd with the large flat stigma, one cell, half-many-cell'd, gaping at the top under the crown with many appertures.

Semina. Seeds, numerous, very small; receptacles, longitudinal folds, of cqual number with the rays of the stigma adhering to the sides of the pericarp. 


\section{Efsential Charaeter.}

PAPAVER, Cor. 4-petal'd. cal. 2-leav'd. capsule one. cell'd, gaping with pores under the permanent stigma,

* With hispid capsules.

\& P. hybridum. Capsules subglobular, brawny, hispid, stem leafy, many-flower'd. mule.

2 P. argemone. Capsules club'd, hispid, stem leafy, many-flower'd.

3 P. alpinum. Capsules hispid, scape one-flower'd, naked, hispid, leaves twice feather'd. alpine.

4 P. nudicaule. Capsules hispid, scape one-flower'd, naked, hispid, leaves simple, feather-sinuous. naked stem.

** With smooth capsules.

5 P.rhocas. Capsules smooth, globular, stem hairy, many-flower'd, leaves feather-cleft, gash'd:

6 P. dubium. Capsules oblong, smooth, stem manyflower'd, with bristles apprefs'd, leaves feather-cleft, gash'd.

dubious.

7 P. sominiferm. Calyxes and capsules smooth, leaves stem-clasping, gash'd. somniferous.

8 P. cambricum. Capsules smooth, oblong, stem manyflower'd, polish'd, leaves feather'd, gash'd. welch.

9 P.orientale. Capsules smooth, stem one-fower'd, rugged, leafy, leaves feather'd, saw'd. oriental. 
The Distinction or Mode of

\section{F L $\quad O \quad W \quad E \quad R \quad I N \quad \mathrm{~N}$ :}

C A L L E D T II E

\section{I $\mathrm{N} F \mathrm{LO}$ R E S C E N C E。}

Complete flowerst are either simple or aggregate: simple, when no part of the fructification is common to many flowers or florets, but is confined to one only; aggregate, when the flower consists of many florets collected into a head by means of some part of the frucification common to them all, as by a common receptacle, or common calyx; as in dipsacus, scabiosa, E̋c.

From the differeut structure, disposition, and other circumstances of the receptacle or calyx, being the only common part to aggregate flowers, arise seven divisions.

1st. AgGREGATE, properly so called, consisting of such flowers as are formed by the union of several lefser \{lowers or florets, placed on partial peduncles, $\$$ on a

common?

* This term is defined to be the mode by which flowers are joined to their several peduncles, whether common or partial.

+ A flower in the Sexual Botany hath a very different signification from the same term of former writers; for if the anthera and stigma be present: though the calyx, corolla, filaments of the stamina, and style of the pistillum be wanting; it is still a flower; and if all the parts are present, it is a complete flower. The seed also constitutes the fruit, whether there be a pericarpiun or not.

\& peduncle is the footstalk of a flower only, ifsuing from the branches: the footstalk of a leaf is called petiole: peduncles are called fastigiate, when there are several, and their lengths so proportioned, that the flowers form a regular surface. The whole flower of the aggregate sort is called flos universalis, and the partial florets are called flores proprii; and each flom ret, in some genera, is a complete frufizication of itsclf, having caly $x_{3}$ corol la, $\mathcal{E}^{\mathrm{c}} \mathrm{c}$. 
common dilated receptacle, and within a common peri. anthium; and in those flowers where each floret hath its proper calyx, that is also a perianthium.

2d. Compound agGreGate, consisting also of several leffer flowers or florets, placed sitting (or without partial peduncles) on a common dilated receptacle, and within a common perianthium; and where cach floret hath its proper calyx, it is also a perianthium. Compound Howers also admit of a further description, (viz.) each floret consists of a single petal, with generally fuve divisions, and having five stamina distinct at the base, but united at the top by the antherce into a cylinder, through which palseth the style of the pistillum, longer than the stamina, and crowned by a stigma with two divisions, that are rolled backwards, and having a single seed placed upon the receptacle under each floret.

This is the general character of a compound. flower, to which there are a few exceptions; it also differs when the flower is radiate; + but the efsential character of a regular floret consists in the antherce being united so as to form a cylinder, and having a single seed placed apon the receptacle under each floret.

3 d. UMBELATE AGGREATE, when the flower consists of many florets placed on fastigiate peduncles procecding from the same stem or receptacle, and though of different lengths, rise to such an height, as to form a regular head or umbel, whether flat, convex, or concave; and both the common and partial calyx,

Linnxus

* The meinbrancous sort of chaffy substance, or lamina, frequenily growingr on the receptack, and intended as a partition between the florets, is called paica (chaff).

+ A flower is said to be radiate, when the florets in the radius or circum. ference differ from those in the disk; in which case they are gentrally larger. and are called semi-florets, from their difference in form, and in distinction from those of the disk, which are called proper florets: and they also differ as to sex, which gives rise to several of the orders in the clars syngenesio. Finch contains the compound flowers; and where they are further explained. 
Limneus calls an involucrum.* It is called a simple umbel, when it hath no lefser divisions; a compound umbel, when each peduncle is subdivided at its extremity into many lefser peduncles for supporting the flowers, so as to form several little umbellas, uniting in one head; the whole together is called an universal umbel, and the little unbellas are called partial umbels. (See the clafs peniandria, order digynia.) In some genera, that have radiated t umbels, the florets of the center and those of the circumference, differ both as to sex and size; but in general each hath five petals, five stamina, and two styles, or one that is bifid, (two-cleft) with a germear placed bencath, and two naked seeds, which when ripe, separate below, but remain connected at the top.

4th. Cymous aggreate, (from cyma, a sprout) called by Linnæus, a receptacle, is when several fastigiate peduncles proceed from the same center, like the zimbel, and rise to nearly an even height; but unlike the umbel, the secondary or partial peduncles proceed without any regular order, $\$$ as in sambucus, viburnum, Ecc.

5th. Amentaceous AGgREGate, are such flowers as have a long common receptacle, along which are disposed squamæ or scales, which form that sort of calyx called an amentum or catkin, as in corylus, pinus, juglans, $E^{3} c$. Amentaceous flowers generally want the petals, and all of them are of the clafises monoecia and dioecia.

6ih. Glumose aggregate, are such flowers as proceed

* The involucrum in umbellate flowers, greatly differs as to the number of leaves; and generally each floret hath a proper perianthium, besides the swo involucres.

+ An umbel is called radiate, when the flowers in the circumference are Jarger than the others; in which case they generally differ as to sex, as in coucus, छ..

Cymose flowers have no common calyx, yet each floret hath a perianthium (generally very small) eitherabove or below the germen. In sambucas and riburnum it is placed above. 
proceed from a common husky calyx belonging to grafses, called gluma; (see clafs trian. digyn.) many of which are placed on a common receptacle called rachis, collecting the florets into the spike, as triticum, hordeam, secale, lolium, Ec.

7th. Spadiceous aggregate, are also such flowers as have a common receptacle, protruded from within a common calyx, called spatha, along which are disposed several florets; such a receptacle is called a spadix, and is either branched, as in phonix, or simple, as in narcifsus, E3c.: In this last case the florets may be disposed, either all around it, as in calla, dracontium, pothos, E3c.; on the lower side of it, as in arum, E3c.; or on two sides, as in zostera, $\mathcal{E}^{3} c$. These flowers have generally no partial calyx.

These are the several distinctions of aggregate flowers, (according to Linnæus;) besides which there are seve. ral other modes of flowering, properly so called, which come under the general term INELORESCENCE; and often afford the best marks to discriminate the species. These modes of flowering are chiefly exprefsed as follows.

1st. Verticilius, * (a virticil, or whirl) wher the flowers are placed in whirls at each joint, round the common stalk ; they have very short partial peduncles,

* The leaves of virticiled plants are fragrant, warm, and aromatic.

+ Common receptacles and common peduncles we must take from Linnxus: he only calls those common receptacles, that belong to aggregaie flowers. proper modes of flowering are sitid to be on common or partial peduncles; and to constitute an aggregate flower, the common receptacle must either be dilated, as in the two first distinctions; or it must be a center from whence the peduncles proceed, as in the umbel and cyme; or it must proceed from, or be connected with a common calyx, as in the other distinctions. Some of the species under the modes of flowering on peduncles, are also aggregate flowers, as being within a common calyx, as oats, panic-gra $\int s$, E्e. under panicula; and some of the species of dianthus, under the furst dissingtion, are called aggregate, though fascicled and headed. 
are all of the lip kind, and have either two or four stamina, and four naked seeds, as in salvia, marrubium, mentha, $E^{2} c$. A verticil hath several distinctions, as naked, bracted, Eंc.; and all those genera with four stamina; are of the clars didynamia.

2d. Capitulum, (a little head) when many flowers are connected into ncarly a globular form or head, on the summit of the common stalk, sometimes with, and sometimes without partial peduncles, as in gomphrena, $\mathcal{E}^{2}$. and is distinguished by its shape, and other circumstances. Under capitulum is now introduced the term Fasciculus, (a little bundle) which in former editions stood distinct. It means when the peduncles are erect, parallel, approaching each other, and raised to the same height, as in dianthus-barbatus, (sweet william) where they generally proceed from different parts of the common stalk, opposite to each other.

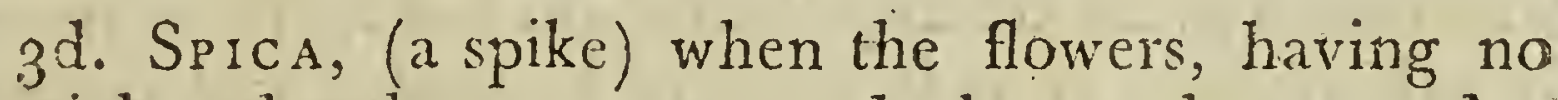
partial peduncles, are arranged alternately around a common simple peduncle; and it is called spica secun$d a$, (a single row'd spike) when the flowers are all turned one way, following each other; and spica disticha, (a double row'd spike) when the flowers stand pointing two ways, as in lolium, $\Xi^{2}$. : and it is distinguished by shape and other circumstances.

4th. Corymbus, (a cluster of ivy-berries) when the lefser peduncles of the flowers proceed from different parts of the common peduncle or stalk; and though of unequal lengths, and sornetimes simple, and sometimes branched, yet form a regular surface at the top; as in the sitiquose plants (clafs tetradmamia). The corymbus may be supposed to be formed from a spike, by adding partial peduncles to the flowers; and seems to be the mean between racemus and umbella, the peduncles rising gradually from different parts of the common stalk, like those of the raceme, and proceed to a proporionable height like those of the umbel. 
5 th. ThY TSUS (a young stalk). $\Lambda$ thyrse is a mode of flowering resembling the cone of a pine: Linnaus saith, it is a panicle contracted into an oval, or eggshaped form; the lower peduncles, which are longer, extend horizontally; and the upper, which are shorter, mount vertically, as syringa, $\mathcal{J}^{3}$.

6th. RAcemus, (a bunch of grapes) it is called a raceme, when the flowers are placed on short partial peduncles, proceeding as little lateral branches, from and along the common peduncle; it resembles a spike in having the flowers placed along a common peduncle; but differs from it in having partial peduncles; it also differs from a corymbus in the shortnefs and equal length of its peduncles, not forming a regular surface at the top; as in ribes-rubrum, vitis, $\mathcal{E}^{3}$.

7 th. Panicula, (the tuft upon reeds, a panicle) when the flowers are dispersed upon peduncles variously subdivided; or it is a sort of branching spike, composed of several smaller spikes, attached along a common peduncle, as in avena, panicum. and several other graises, and many other plants. When the partial peduncles diverse and hang loose, it is called a diffuse, and when they converge, it is called a close panicle.

To these may be added the term Axilitariss, (from axilla, the arm-pit) being such flowers as proceed from the angle formed by the leaf and the stem, as is most common: And Terminales, being such flowers as terminate the stalk or branch. Also every other mode of flowering is called the Inflorescence, whether opposite the leaves, hateral, single, double, erect, bending, \&c.

Under this head of Inflnescence may be explained LUXURIANT FLOWERS, (commonly called double flowers) which, as they are considered only as varieties and unnatural, belong properly to the head, Habit of plants. A luxaringt flower is supposed gencxally 
rally to be owing to supcrabundant nourishment; the luxuriant part is generally the corolla, but sometimes the calyx also. It is divided into three degrees: 1 st. multiolicalus, 2 d. plemus. 3 d. prolifer. To which may be added, as an opposite imperfection, fos mutilatus.

1st. Multiplicatus. (multiplied) when the petals of the corolla are only so far multiplied, as to exclude part of the stamina: and is called duplicate, triplicate, quadruplicate, 83 . according to the number of rows of petals.

2d. PLENUS, (full) when the corolla is so much mul. tiplied, as to exclude all the stamina; which is occasioned by the stamina running petals; and the flower is often so crowded, as to exclude or choak the pistillum also. Thercfore, as the efsential parts of generation are thus wholly, or in part destroyed, the plants become barren or imperfect, and no seed, or very little, can be expected from them.* Flowers with one petal are not very subject to fulnefs, when they are, it generally arises from an increase of the divisions of the petal. It is most usual in flowers of many petals, where it arises various ways; sometimes by multiplication of the petals only, sometimes of the calyix or nectarium, and sometimes of all. Compound flowers are also subject to luxuriance, arising several ways.

3d. Prolifer, (prolific) when one flower grows out of another; this generally happens in full flowers, from their greater luxuriancy; in simple flowers, it rises from the center, and proceeds from the pistillum shooting up into another flower, standing on a single footstalk. In aggregate flowcrs (properly so called) many footstalked flowers are produced out of one common calyx. In umbellate flowers, a second umbel proceeds from the cen. ter of the first umbel, producing little umbels; which E 2

by

* A remarkable instance of plentitude is in the geider rose, friburnum opulus; where all the flowers are iaren. 
by a greater exertion of luxuriancy may produce others with little umbels, and thus may proceed several heads of flowers, each growing out of that immediately below it, furnished with little umbels variously compounded. A prolific flower is also called leafy, (frondosus) when it produceth branches with flowers and leaves, which though rare, sometimes happens in rosa, ancmone, monarda, and others.*

Flos mutilatus (a mutilated or maimed flower) is such a flower, as occasionally is deprived of all, or the greatest part of the petals, yet bears seeds, as in some species of tufsilago, campanula, ${ }^{3} \mathrm{c}$. This term is: opposed to huxuriance, and is supposed by Linnxus to be caused by a defect of heat, though it may also happen by other causes.

Under this head of flowers, may also be mentioned the different sexes.

$\mathrm{F}_{\mathrm{LO}} \mathrm{OWER} \mathrm{S}$, in respeet to $\mathrm{SEX}$, are distinguished into. male, female, hermaphrodite, and newter. Male flowers are such as have only the stamina or males, as in the clatses monoecia, dioecia, and polygamia. Female flowers are such as have only the pisiilla or females, as in the same clafses monoecia, dioecia, and polygamia. Hermaphrodite flowers are such as have both the stamina and pistilla in the same flower, as in all the other clafses: hermaphrodites are also distinguished into male hermaphrodites, when the female is ineffectual; and female hermaphrodites, when the male is ineffectual. Neuter flowers are such as have neither stamina nor pistilla perfect; see the clals syngencsia. The plants themselves also take a denomination from the sex of their flowers;

* As in luxuriant flowers many parts of the natural character are deficier in the whole or in part, they can only be distinguished by the general habit, and by such parts as remain in the natural state; is very often by the calyr., and in polypetalous flowers, the lowest series or rows of petals remain the same, as in rosa, papazer, nigella, $\mathcal{E}^{2}$. 
Hlowers; as male plants are such as bear male flowers only; female plants are such as bear female flowers only; hermaphrodite plants are such as bear hermaphrodite flowers only. Androgynous (male and female) plants are such as bear both male and female flowers, distinct, upon the same root, as in the clafs monoecia. Polygamous plants are such as bear hermaphrodite flowers, and male or female flowers, or both distinct, on the same or on different roots: if on the same root, the flowers are either male hermaphrodites and female hermaphrodites: or hermaphrodites and male; or hermaphrodites and female, distinct: if on different roots, the flowers are either hermaphrodites and male; hermaphrodites and female; hermaphrodites and both male and female; or are androgynous and male; and sometimes androgynous and male and female on three distinct plants.-See the clars polygamia..-See also the clafs sengenesia, where polygamy gives rise to the orders of the compound flowers.

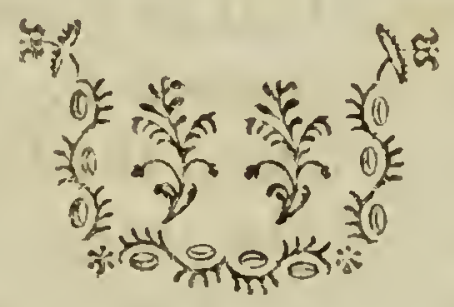




\section{OUTLINES OF A PLANT.}

A PLANT principally consists of root, tmenk, -1 leaves, props, fructification, and inflorescence; and also the habit.

I. The ROOT consists of two parts, (riz.) the caudex and the radicula, distinguished according to shape, direclion, duration, \&c.

CAUDEX (a stump) is the body or knob of the root, from which the trunk and branches ascend, and the fibrous roots descend; and in different plants is either solid, bulbous, (pláced under a bulb) or tuberous. Solid, as in trees, shrubs, and many of the herbs. Bulbous will be explained under hybernacle. Tuberous knobs are also solid and hard, containing one or more embryos or eyes; and are either only one knob, as turnep, carrot, E3c. containing only one eye at the top; or consist of many knobs connected together by slender fibres, as in potatoes, jerusalem artichokes, Esc. each containing many eyes dispersed over the surface; and are either pitted, when the eyes lie inward, as in potatoes, $8 \mathrm{c} . ;$ or tuber. cul'd, containing the eyes outward, as in jerusalem artichokes, E्E. In tuberous knobs, the fibres or stringy parts ifsue from every part of the surface, which is an efsential difference from bulbous knobs, where they are confined to the caudex of the bulb only, and are the true and genuine roots; the bulb itself being only a large bud under ground.

RADICULA

* Those tuberous knobs with only one eje, differ as to duration, but are in general bicmulal; those with many eyes are perennial; both seem to be produced by the nutriment of the stem like buds, and not by the fibrous roots, for the stem is first formed and becomes strong, and as it grows to maturity, the tuberous knobs increase. 
Ranicula (a little root) is the stringy or fibrous part of the root, descending from the caridex; and is really the principal and efsential part of every root, and by which the nourishment is drawn from the earth for the support of the plant.

II. The TRUNK, which includes the branches, is that part which rises immediately from the candex, and produceth the leaves, flowers, and fruit. It is either herbaccous, shrubby, or arborescent; and is distinguished according to its shape, substance, surface, \&c. and admits of the following sorts, (viz.) caulis, culmus, scapus, stipes.

1st. CAULrs (a stalk or stem) is the main or universal trunk, which elevates the leaves and fructification, and is applied to trees, shrubs, and herbs: It is either simple or compound; simple, when it doth not divide: compound, when it is divided into branches.

2d. Culmus (a straw, or haulm) is the proper trunk of grafses; and also elevates both the leaves and fructin fication: It is sometimes jointed, and sometimes not; it is also sometimes round, and sometimes angular.See the clais and order triandria digynia.

3d. Scapus (a stalk) is an herbaceous trunk, whicl elevates the frustification, but not the leaves; that is, it is a stalk proceeding immediately from the root, and terminated by the flowers, as in narcifsus, hyacinil, $\varepsilon^{3} c$.

4th. STIPEs, (a trunk) used by Linnxus for the trunk of mushrooms; as also for that slender thread or footstalk which elevates the feathery or hairy down, with which some seeds are furnished, and connects it with the seed.

III. The LEAVES, which are said by Linnæus, to be the muscles or organs of motion of a plant; by others, the organs by which perspiration and inspiration are performed. They are defined as proceeding 
from the expansion of the vefsels of the stalk, forming scveral ramifications like net work, extended in length and breadth in a determinate manner, having the interstices filled up with a tender pulpy substance; and the external covering is supposed to be a continuation of the scarf skin of the stalk.

Leaves are either simple or compound, and are distinguished by their figure, situation, insertion, number, divisions, E?.

A Simple Leaf, is such as either adheres to the branch singly, or whose footstalk is terminated by a single simple expansion, not parted to the middle rib; and is determined by its shape, surface, and divisions.

A COMPOUND LEAF, is such whose footstalk is furnished with several separate simple expansions, or in other words, whose divisions extend to the middle rib; now called a common petiole, (or footstalk) supporting several lobes, or little simple leaves, of which the compound leaf consists; and are distinguished by shape, \&c. and the form by which they are attached to the common footstalk, as palmated, winged, feathered. E'c. Sometimes leaves are twice or more compounded, which divisions admit of many modifications, and give rise to as great variety of terms. It may sometimes be difficult, at first sight, to know a common footstalk to a compound leaf, from a branch; but it may be observed. that a common footstalk, where it ifsues from the branch, is either flat or hollow on one side, and convex on the other; whereas branches are alike on both sides, whether round, flat, or angular: again, buds are never found at the angles formed by the lobes of a compound leaf with the footstalk; but at the angles formed by the footstalk of the whole compound leaf and the stem.*

And

* The flowers in fruit trees generally appear before the leaves, that the procefs of inpregnation may not be intermpted. 
Ind it may always certainly be distinguished by its falling off with the little leaves which it supports.

The manner or place in which leaves are attached to the plant, is called the DITERMINATION of leaves: and is as follows, distinguished by several terms, ac. cording to number, disposition, insertion, figure, $\mathcal{B}^{3} \mathrm{c}$.

RADICAL or ROOT LEAF, such as proceed from the root.

STEM LEAF, such as grow on the stem.

BrANCH LEAF, such as grow on the branches,

AXILlARY LEAF, (from axilla, the arm pit) such leaves as grow in the angle formed at the insertion of the branch with the stem.

Floral Lear, (forale) such as are placed nearest to the flower, and never appear without it (sce bractea, page 34). There are also seminal or secd leaves, such as are first the cotyledons, and afterwards become leaves; but these are not noticed under determination of leaves, as not coming under the definition of a leaf.

IV. The PROPS, (fulcra) a term used to exprefis those external parts which strengthen, support, or defend the plants on which they are found, or serve to facilitate some necefsary secretion; and are as follow.

1st. Petrolus, the footstalk or support of a leaf.

2d. PEDUNCULUS, the footstalk or support- of a flower.

$3 \mathrm{~d}$ STIPULA, (haulm or husk) a sort of scale or small leaf, stationed in most plants (when present) on each side the base of the footstalk of leaves and flowers, at their first appearance, for the purpose of support: They are placed either single or double, and sometimes on the inside, as in the fig and mulberry; or on the outside, as in the birch, lime, and papilionaceous flowers: They are also either sititing, extended downwards, or sheathing along the stem, as in the plane tree. As to F

duration, 
duration, they sometimes fall before the lcaves, and sometimes are equally permanent: They often afford a. good distinction for the species.

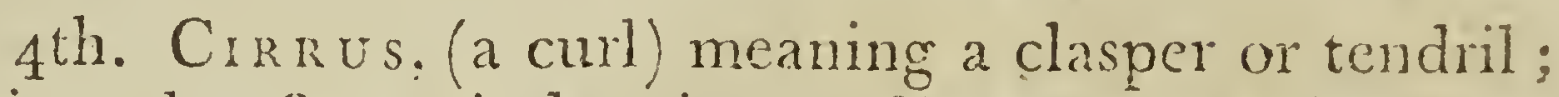
being the fine spiral string or fibre, by which plants. fasten themselves to some other body for support: They are sometimes placed opposite the leares, sometimes at the side of the footstalks of the leaves, and sometimes ifsue from the leaves themselves; and sometimes they put out roots, as in ivy, Esc.

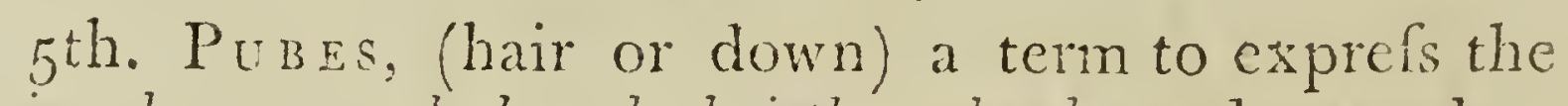
hair, down, wool, beard, brislles, glands, and several o. ther appearances, on different parts of plants, serving the double purpose of defence and vefsels of secretion.

6th. AnMa, (arms) the defensive weapons of plants; which are cither spina, (a thorn) protruded from the wood of the plant: aculeus, (a prickle) proceeding from the coricx or outer bark of the plant, which are sometimes forked or divided, consisting of two or more prongs or divisions; or stimuli, (stings) producing inflammatory itching punctures to the naked parts of animals, by their venomous points.

7th. BRACTEA, (thin plates of metal) are the foral leaves, (floralia folia) and mein not only those leaves situated on the stalk nearest to the lower parts of the Hower, but they sometimes terminate the flower stalk: being composed of large bractea, resembling a bush of hair, (coma) and are then called braftec comose, as in croun-imperial, lavender, and some species of sage.Sce bradiea under calyx.

V. The FRUCTIFICATION, or mode of frutibearing, consisting of the calyx, corolla, stamina, pistit. lum, pericarpium, semina, and receptaculum; all which have been already explained.

VI. The INFLORESCENCE, which is defined to be the mode by which fowers are joined to their several 
several peduncles, whether common or partial; as hath been already explained.

VII. The HABI'T of plants, by which antient botanists meant the whole external appearance of every part thereof, whereby they were arranged in their several systems; but by Linnzus it is meant to be the agreement of plants of the same gemes or natural order; chicfly in the following circumstances.

Gemation. The structure and disposition of the bulb, as solid, coated, scaly, stem-bulb.

Also of the bud, its origin petioled, stipuled, cortical; its contents leafy, floral, common.-See hybernacle.

Femation. The complication of the Ieaves within the but, at spring, as conduplicate, convolute, involute, revolute, imbricated, equitant, obvolute, plaited, spiral.*

Estivation. The state of the bud (which flowers) in summer, as convolute, imbricated, conduplicate, valved, unequal-valved.

Tortion. The twisting oi bending of the parts, as uniform, difsimular, from the right, from the left, reciprocal, resupine, spiral.

Nuptials. Male, female: androgynous, hermaphro. dite.

Semination. The shape and other circumstances of the secd, as tail, wing, tuft, awn, hooks, gluten, curviture.

Also

\footnotetext{
* Conduplicate, (doubled together) as in oak, hazel, rualnut, Ec.

Convolute, (rolled together) as in bean, saxifrage, $\mathrm{E}_{\mathrm{c}}$.

$\begin{array}{ll}\text { Invelute, } & \text { (rolled in) as in apple, pear, Ese. } \\ \text { Revolute, } & \text { (rolled back) as in primrose, }\end{array}$

Imbricaied,

Equitant,

(rolled back) as in primrose, groundsel, colt's-foot, $\mathcal{E}^{2} \mathrm{c}$.

(tiled) is in lilac, campanula, Esc.

Obrolite,

Ilaiter,

Sijiral,

(riding) when the opposite margins approach, so as one to inciude the other, ais in iris, swet-rus?, Esc.

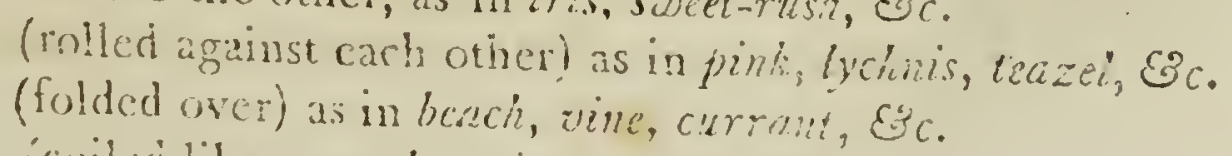

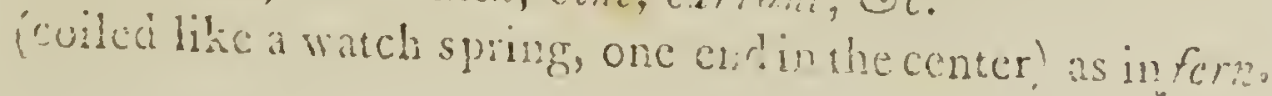


Also of the pericarp. as berrying, inflation, viscosity, elasticity, siructure.

Placentation. The number and disposition of the cotyledons; or if wanting.

Vuriation. Of color, size; pubescence, age.

External. plaited, bundled, broad-leaved, curled, awnlefs.

Internal. mutilated, great-flowered, luxuriant, crested; viviperous, bulbbearing.

By variation or variety are meant such differences as are only incidental to vegetables, and are not found constant and unchangeable; that is, where plants raised from the same seed, by some accidental cause differ in form and appearance, from the true character of the species to which they belong; which cause being removed, the plant is restored to its true specific character: and these incidental varieties chiefly arise by diffrence of soil or culture, in some of the above circum. stances.

And though it is as necefsary to colleet varieties inder their proper species, as the species under their proper genera; yet it is often more difficult ; first, from the difficulty of ascertaining the genius, and secondly, from the variety confounding the species; $*$ and sometimcs some parts of the specific character itself are also subject to variety, particularly the leaves; though in goneral the true specific character is constant and unchangeable,

* Sue the note at the end of luxuriant flowers. The name that constiwhes the varicty is to be placed immediately after the specific name, as flore biene, currḯa mura, Be.

t In respect to leaves, which are mencioned as a distinetion of species, ret subject :o variety, it may be necelsay to observe, that in general the leaves are corstant as to figure and sisuation; but vary in respect to number of fingers or bobes in digitzted and winged leaves, and in growing by tireces, fours, or five: curled and variegated leaves are also a fregucnt vartety, and and they often dirfer as to size and color. 
changeable, arising only from such circumstances wherein plants of the same genus are found to disagree, which distineions are commonly taken with most certainty, from the following parts, (viz.) root, trunk, leaves, fulcra, hybernacle, inflorescence: all which parts have been already explained, except hybernacle.

The HYBERNACLE, (winter lodgment) is that part of a plant which defends the embryo or future shoot from external injuries during the winter; and according to Linnæus, is either a bulb or a bud.*-See gemmation under habit.

I. A BuLB (bulbus) is a large sort of bud produced under ground, placed upon the caudex of certain herbaccous plants; hence called bulbous plants; all of which are perenniel, that is, perpetuated by their bulbs or ground buds, as well as by seeds; they are therefore improperly called roots, being only the hybernacle of the future shoot. Bulbs are of the following sorts.

1st. A scaly Bulb, (bulbous squamosus) consisting of scales laid over each other like tiles, as in the lily.

2d. A solid bulb, (solidus) consisting of a solid substance, as in tulips.

3d. A coated bulb, (tunicatus) consisting of many coats infolding cach other, as in onions.

4th. A stem Bulb, (caulinus) which is produced not only from the sides of the principal butb, called a sucker or offset; but from other parts of the stem; as in crow or wild garlic, and in sorne species of onion (hence called buibiferous); where they are produced at the origin of the umbel of flowers.

\section{A Bud (gemma) is the embryo of the plant seated}

* Titberous roots, might by the same definition, with equal propriety, be called hybernacles. - Gther bulos, besides those here mentioned, were for merly cnumerated, (viz.) the jointed bulb, as in moschatel; and the double sulb, as in orchis. 
seated upon the stern and branches, covered with scales. In general there are three sorts of buds :- -1 st. that containing the flower only, as in poplar, ash. Ec. where the leaf-buds and flower-buds are distinct:-2d. that containing the leaves only, as in birch, $\mathcal{J}^{2}$ c.: - and 3 d. that containing both flower and leaves, as in the generality of plants; and these last sometimes contain leaves and male flowers, sometimes leaves and female fowers, sometimes leaves and hermaphrodite flowers.

Annual plants are only renewed from secds, and several other plants, both trees and slirubs, have no winter buds: It is also observed in hot countries, that few plants have buds, or at least they are without that scaly covering, which seems efsential to a bud, and constitutes the hybernacle; instead whereof are protruded small feather-like branches from the wings of the leaves; (defence and protection from cold not being necefsary ;) whereas in cold countries most plants have buds, which are wraped up all the winter in ready nefs to greet the approaching spring.

I may lastly take notice of what is called the SLEEP of plants, which according to Linnæus happens various ways, as by converging, including, surrounding: fortifying, conduplicating, involving, diverging, depending. inverting, imbricating. This disposition in plants is very remarkable in chickweed, pimpencl, dandelion, goal's-beard. $3 \%$. which expand their flowers only at certain times of the day, and shut them up at the approach of night or a storm; which shews the great care mature takes to protect and invigorate her feeble offspring; from hence may often be prognosticated a change of weather. And in many plants, not only the flowers, but the young shoots are defended from external injuries, by the nearest leares converging and in. closing the tender rudiments. 


\title{
I A B L E
}

\section{CLASSES AND ORDERS:}

\author{
ACCORDING TO THE
}

SystemaVegetabilium \& Supplementum Plantarunt.

CLASSES.

1 MONANDRIA.

2 DIANDRIA.

3 TRIANDRIA. $\left\{\begin{array}{l}1 \text { Monogynia. } 2 \text { Digynia. } \\ 3 \text { Trigynia. }\end{array}\right.$

4 TETRANDRIA. $\left\{\begin{array}{l}1 \text { Monogynia. } 2 \text { Digynia. } \\ 3 \text { Tetragynia. }\end{array}\right.$

5 PENTANDRIA. $\left\{\begin{array}{l}1 \text { Monogynia. } 2 \text { Digynia. } \\ 3 \text { Trigynia. } 4 \text { Tetragynia. } \\ 5 \text { Pentagynia. } 6 \text { Polygynia. }\end{array}\right.$

6.HEXANDRIA. $\left\{\begin{array}{l}1 \text { Monogynia. } 2 \text { Digynia. } \\ 3 \text { Trigynia. } 4 \text { Tetragynia. } \\ 5 \text { Polygynia. }\end{array}\right.$

7 HEPTANDRIA. $\left\{\begin{array}{l}1 \text { Monogynia. } 2 \text { Digynia. } \\ 3 \text { Tetragynia. } 4 \text { Heptagynia }\end{array}\right.$

8 OCTANDRIA. $\left\{\begin{array}{l}1 \text { Monogynia. } 2 \text { Digynia. } \\ 3 \text { Trigynia } 4 \text { Tetragynia. }\end{array}\right.$

9 ENNEANDRIA. $\left\{\begin{array}{l}1 \text { Monogynia. } 2 \text { Trigynia. } \\ 3 \text { Hexagynia. }\end{array}\right.$

10 DECANDRIA. $\left\{\begin{array}{l}1 \text { Monogynia. } 2 \text { Digynia. } \\ 3 \text { Trigynia. } 4 \text { Pentagynia. } \\ 5 \text { Decagynia. }\end{array}\right.$

11 DODE. 

CLASSES.
$O R D E R S$.

1. DODECANDRIA. $\left\{\begin{array}{l}1 \text { Monogynia. } 2 \text { Digynia. } \\ 3 \text { Trigynia. } 4 \text { Pentagynia. } \\ 5 \text { Dodecagynia. }\end{array}\right.$

12 I COSANDRIA. $\left\{\begin{array}{l}1 \text { Monogynia. } 2 \text { Digynia. } \\ 3 \text { Trigynia. } 4 \text { Pentagynia. } \\ 5 \text { Polygynia. }\end{array}\right.$

i3 POLYANDRIA. $\left\{\begin{array}{l}1 \text { Monogynia. } 2 \text { Digynia. } \\ 3 \text { Trigynia. } 4 \text { Tetragynia. } \\ 5 \text { Pentagynia.6 Hexagynia. } \\ 7 \text { Polygynia. }\end{array}\right.$

14. DIDYNAMIA. $\left\{\begin{array}{l}1 \text { Gymnospermia. } 2 \text { An- } \\ \text { giospermia. }\end{array}\right.$

${ }_{25}$ TETRADYNAMIA. 1 Siliquosa. 2 Siliculosa.

16 MONADELPHIA. $\left\{\begin{array}{l}1 \text { Triandria. } 2 \text { Pentandria. } \\ 3 \text { Octandria. } 4 \text { Decandria. } \\ 5 \text { Endecandria. } 6 \text { Dodecan- } \\ \text { dria. } 7 \text { Polyandria. }\end{array}\right.$

17. DIADELPHIA. $\left\{\begin{array}{l}1 \text { Pentandria. } 2 \text { Hexandria. } \\ 3 \text { Octandria. } 4 \text { Decandria. }\end{array}\right.$

58 POLYADELPHIA. $\left\{\begin{array}{l}1 \text { Pentandria. } 2 \text { Icosandria. } \\ 3 \text { Polyandria. }\end{array}\right.$

19 SYNGENESIA. $\left\{\begin{array}{l}1 \text { Polygamia xqualis. } \\ 2 \text { Polygamia supertia. } \\ 3 \text { Polygamia frustrarea. } \\ 4 \text { Polygamia necefsaria. } \\ 5 \text { Polygamia segregata. } \\ 6 \text { Monogamia. }\end{array}\right.$

20. GYNA N R IA. $\left\{\begin{array}{l}1 \text { Diandria. 2 Triandria. } \\ 3 \text { Tetrandria. } 4 \text { Pentandria. } \\ 5 \text { Hexandria. } 6 \text { Octandria. } \\ 7 \text { Decandria. } 8 \text { Dodecan. } \\ \text { dria.9 Polyandria. }\end{array}\right.$ 


\section{B O T A I I A.}
CLASSES.
$O R D E R S$.

2. MONOECIA.

1 Monandria. 2 Diandria. 3 Triandria. 4 Tetrandia. $\{$ Pentandria 6 Hexandria. 7 Heptandria. 8 Polyandria 9 Monadelptid. 10 SynLenesia. 11 Gynandria.

1 Monandria. 2 Diandria. 3 Tridndria. 4 Tetrandria. 5 Pentandria. 6 Hexandria. 7 Octandria. 8 Enneandria. 9 Decandria. 10 Dodecandria. 11 Polyandria. 12 Monadelphia. 13 Syngenesia。 ${ }_{14}$ Gynandria.

22 DIOECIA.

$2_{3}$ POLYGAMIA. $\left\{\begin{array}{l}1 \text { Monoccia. } 2 \text { Dioecia. } \\ 3 \text { Trioecia. }\end{array}\right.$
24 CRYPTOGAMIA. $\left\{\begin{array}{l}1 \text { Filices. } 2 \text { Musci. } \\ 3 \text { Algæ. } 4 \text { Fungi. }\end{array}\right.$ APPENDIX. Palma. 
NoTE. The number of the genera and species, and accenting of the genera, are taken from the Systema Vegetabilium and Supplementum Plantarum, as translated and incorporated by the Litchfield Socicty, 1783 .

The distinctions of the genera in the several orders, arc taken from the synopsis to cach clafs, in the same publication.

'The growth, and places where principally native, are chiefly taken from the Species Plantarum.

The number of species indigenous to the British Isles, are taken from Broughton's Ecnhiridion Botanicum.

In the column under grouth; t stands for tree; s, for shrub; and $h$, for herb.

Vegetables, saith Linnæus, hath life without voluntary motion; but his System makes no difference between trees, shrubs, and herbs, yet the distinction is of great antiquity with other writers: The difference hetween trecs and herbs are very obvious; but the limit between trees and shrubs are not accuratcly ascertained. Linnatis thinks the bud is the best distinction, trees having buds, and shrubs no buds; but he immediately acknowledges this distinetion to be fallaceous, as many large trees in hot climates have no buds. Dr. Alston thinks the difference lies in the bark, that trees have an outer and inner bark, (cortex and liber) and generally a sap, (alburnum) but that the covering to shrubs is not a bark but a cuticle or simple skin; but this wants confirmation. We can therefore only say that a trec is a perennial plant rising to a great height, with a simple, woody, durable, branching trunk, producing wood fit for timber: The same definition holds with respect to shrubs, only that they do not rise to so great an height, the trunk not so simple, the branches more bushy, and not pro* ducing timber.

An heru is a plant with a succulcnt stem or stalk, not woody, and which generally dies down to the ground every year, but is sometimes biennial.

The duration of plants Linnæus thinks so inconstant, that he never employs it in specific diflerences. In hot climates that have at perpetual sumincr, most plimts are trees or shrubs, or at least percmial; yet many, when removed to colder cliniates, lnose their woody substance, and become herbaccous, and somerimes annual, as ricimus, mirabilis, tropacium, beta, origa. nim, lavetern, 


\section{$\left[\begin{array}{lll}4 & 4 & \end{array}\right]$}

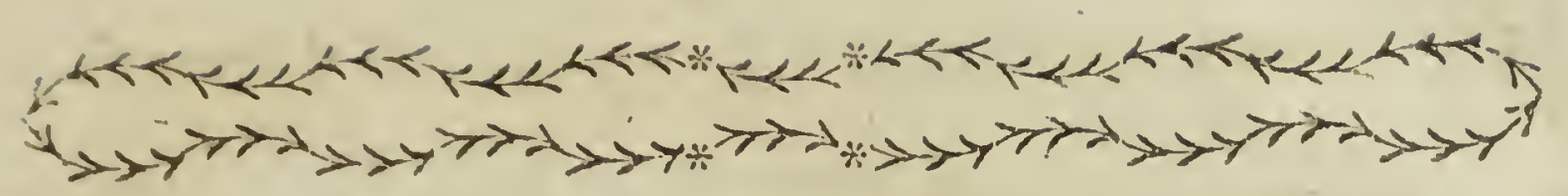

TH E

\section{Clafses, Orders, and Genera:} ACCORDING TO THE

\section{SEXUAL SYSTEM OF LINNEUS.}

\section{Class I. M O N A N D R I A.}

\section{(One stamen or male.)}

Consisting of such plants as bear hermaphrodite flow. ers, furnished with only one stamen or male.

And, to avoid repetition, it may be observed, that all the clafses, except the last four, and part of the clats syingenesia, regularly consist of what Linnæus calls hermaphrodite flowers; that is, have the antherce and stig. ma in the same flower.*

This clafs contains two orders.

\section{Order I. MO N O G Y I $A$. (One fenale.)}

Containing such plants as have only one pistillum or female: under the following distinctions.

$$
\mathrm{G}_{2}
$$

1st. Scitas

* It would have beon more pleasing to delicacy, if Linneus had substiiuted some term exprefsive of the marriage state, instead of hermaphroutc; as it also causes so great a difference in the sexwal analogy between plants and animals: If any flowers can with propriety deserwe the appellation. they are those of the clars gyondria, which are monsters from all others. 
1st. Scitamineous* beneath; or fruit cell'd beneath.

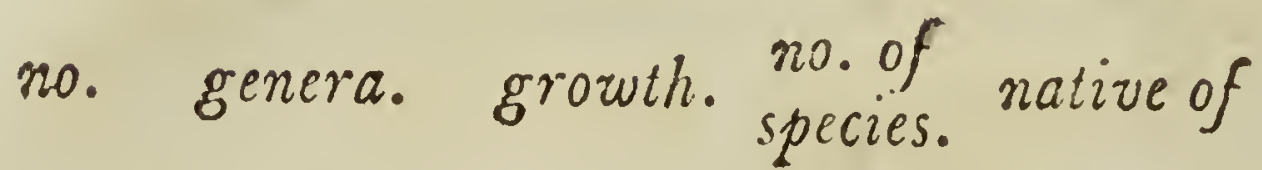

species

1 Alpinia,

h 1 America.

2 Amomum,t

h 4 W. Indies.

3 Canna,

h 3 America.

4 Costus,

5 Curcuma,

6 Kæmpteria,

h 1 Arabia and Indies.

7 Maranta,

8 Myrosma,

9 Renealmia,

10 Thalia,

$\mathrm{h} 2$ India.

h 2 E. Indies.

h 3 India.

h 1 Surinam.

h 1 Surinam.

h 1 America.

\section{2d. One-seeded.}

11 Boerhaavia,

12 Hippuris,

13 Salicornia,

h 6 La-vera-crux.

h 2 Europe. Brit. 1

h 6 Arabia.

Brit. 2

\section{Order II. D I G Y N I A.}

(Two females.)

sst. Plants.

14 Blitum,

15 Callitriche,

16 Corispermum,

17 Cinna,

18 Mniarum, h 2 Spain. Tartary.

h 2

h 2 Tartary.

2d. Grafsy.

h 1 Canada.

h 1

Brit. :

CI.AsS

* Scitamineous, (from scitanentum) because some of the plants afford de. yicious fruit. Scitaminece is also the name of the 8th. order in Linnaus's Frngments of a Natural Mithod, containing most of the ahove plants.

+ Cardamom seeds are from a species of amomum, called amonum carda: momum. 


\section{[ 45.$]$}

\section{Class II. D I A N D R I A.*}

(Two stamina or males.)

Containing three orders.

\section{ORDER I. MONOGYNIA.}

\section{(One female.)}

1st. Flowers beneath, one-petal'd, regular.

20. genera. growth. no. of natives.

1 Chionanthus, s 2 South Carolina.

2 Eranthemum, s 4 Eiopia.

3 Jasminum, s 6 India.

4 Ligustrum, s. 1 Brit. 1

5 Nyctanthes, s 7 India.

6 Olea, $\quad s \quad 3$ Spain.

7 Phillyrea, s 3 Europe.

8 Syringa, $\$ 2$ Persia.

2d. Flowers beneath, one-petal'd, irregular.

Fruit copsul'd.

9 Calceolaria,

10 Dianthera,

11 Gratiola,

1.2 Justicia,

13 Prderota,

14 Pinguicula,

1.5 Schwenkia,

h $\quad \begin{aligned} & 4 \\ & \text { America. }\end{aligned}$

h 6 Alps. America.

s\&h. 29. Ceylon, \&c.

5 Africa.

h 4 Portugal.

1 America.
Brit. 2

16 Veronica,

* Several plants of this clafs diandria, are so similar to many of the clafs didynamin, that it is often very diffeult in distinguish them: The flowers are nearly of the same form, and though many, have properly. only. two stamina (the other wo wanting anthera); yet have flaments so very like stamina, that botanists have sometimes confounded the two clafses, as to. several plants. 
30. genera. grouth. no. of native of species. 16 Veronica, h 41 America. Brit. 15 17 Utricularia, h 9 Alps. Brit. 2 3d. Flowers beneath, one-petald, irregular. Fruit seed-naked.

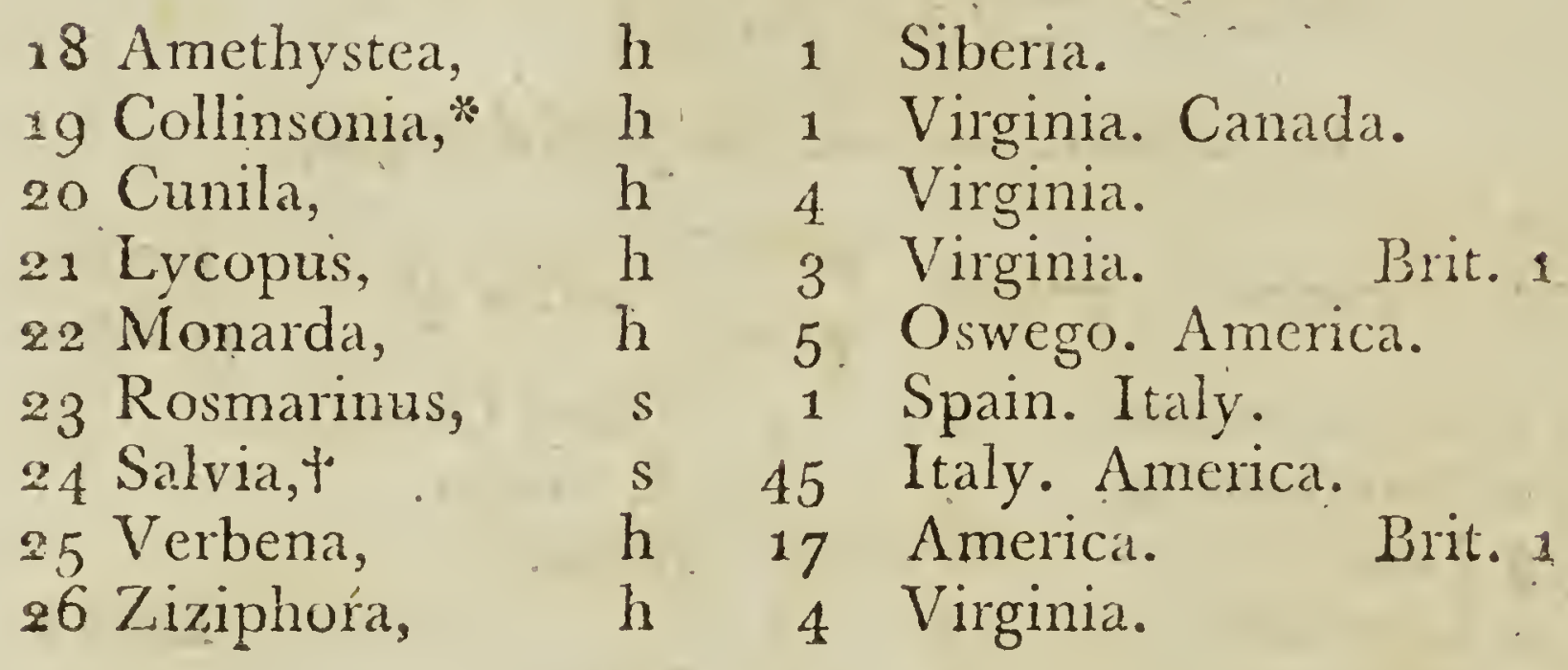

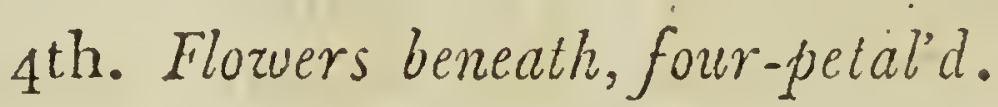

27 Thouinia,

1 Spain.

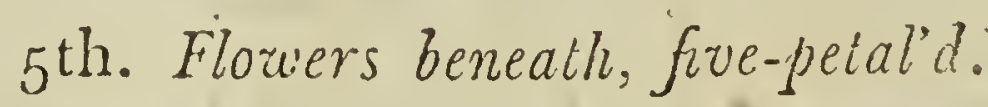

28 Dialium,

1 India.

6th. Flowers above,

29 Ancistrum,

1 New Zealand.

$3^{\circ}$ Circxa,

If In utricularia (bladder-wort) the roots are loaded with membranaceous bladders.

* It hath been obṣerved in many plants, as in saxifraga and bn runfsia, that the stamina make the first advances by bowing down in their turns to the female; but in collinsonia canadensis the lady seems to make the first advance, by bowing first to one of her husbands for a day or two, and then to the other.

+ In salvia, the singular crols thread of the stamina constitutes the efsential character of the genus: the rudinents of two stamina appear in the mouth of the flower, but have no anthera. - Sage and clary are distinet plants by" other writers, but by Linnaus, they both cone under the genus salian, notwithstanding some little difference in the flower. 


\section{I A N D R I A.}

no. genera. growth. $\begin{gathered}\text { no. of necies. native of in Brit. } \\ \text { inecies }\end{gathered}$ 30 Circæa, $\quad$ h, 2 France. Alps. Brit. 2 31 Globba, 3 E. Indies. 3. Morina, h y Persia.

\section{ORDER II. DI G Y N IA.}

(Tíwo females.)

33. Anthoxanthum, h

5

Brit. I

Order III. TR I G Y N I A. (Tiree females.)

34 Piper, $\$$

$\therefore$ s $h 25$ E. and W. Indies.

$\$$ The leaves of the piper-betle are esteemed cordial, and give a fine fla* vour to the breath, for which they are much used in the East. 


\section{$\left[\begin{array}{lll}4 & & \\ 4 & -1\end{array}\right.$}

\section{Class III. T R I A $\mathrm{N} D \mathrm{R} I \mathrm{~A}$.}

(Three stamina or males.)

Containing three orders.

\section{ORDER I. MONOGX N I A. \\ (One female.)}

1st. Flowers above.

no. genera. growth. no. of native of species.

I Antholyza, h 8 Africa.

2 Crocus,

3 Dilatris,

4 Gladiolus,

h 3

h 3 Cape.

5 Iris,

6 I xia,

7 Melothria,

8 Mora.

h 24 Europe.

9 Valeriana,

h 39 Europe.

Brit. 3

s \& h 28 Alps. Africa.

h 1 Virginia.

h. 13 Africa.

h 27 France.

Brit. \&

2d. Flowers beneath.

1o Callisia,

11 Cneorum,

12 Commelina,

13 Comocladia,

14 Hippocratea,

15 Loeflingia,

16 Olax,

17 Ortegia,

18 Polycnemum, h I America.

s 1 Spain.

h 4 W. Indies. Africa.

$\mathrm{s} 2$ America.

h 2 America.

h 1 Spain.

$t \quad 1$ Ceylon.

2 Spain.

h 1 France. Italy.

* Valerians differ greatly in several parts; as in the corclla being regular or irregular; in the stamens being $1,2,3$, or 4 ; the fiut one-seeded, of two-seeded, naked, crowned with a pappus, \&c. - These plarts may be geverally known (when not in flower) by the roots being scented: and two leaves at cach joint opposite. 


\section{T R I A N D R I A.}

no. Eenera. growth. $\begin{aligned} & \text { no. of native of species. } \\ & \text { in Brit. }\end{aligned}$

19 Rotala,

20 Rumphia,

21 Tamerindus,

22 Wackendorfia, h

23 Willichia,

24 Xyris, h 1 E. Indies.

$s \quad 1$ Amboyna.

$t \quad 1$ E. and W. Indies。

h 4 Africa.

h 1 Mexico.

1 India.

3d. Flowers grafsy, with vaiveleis of the calyx-glume.

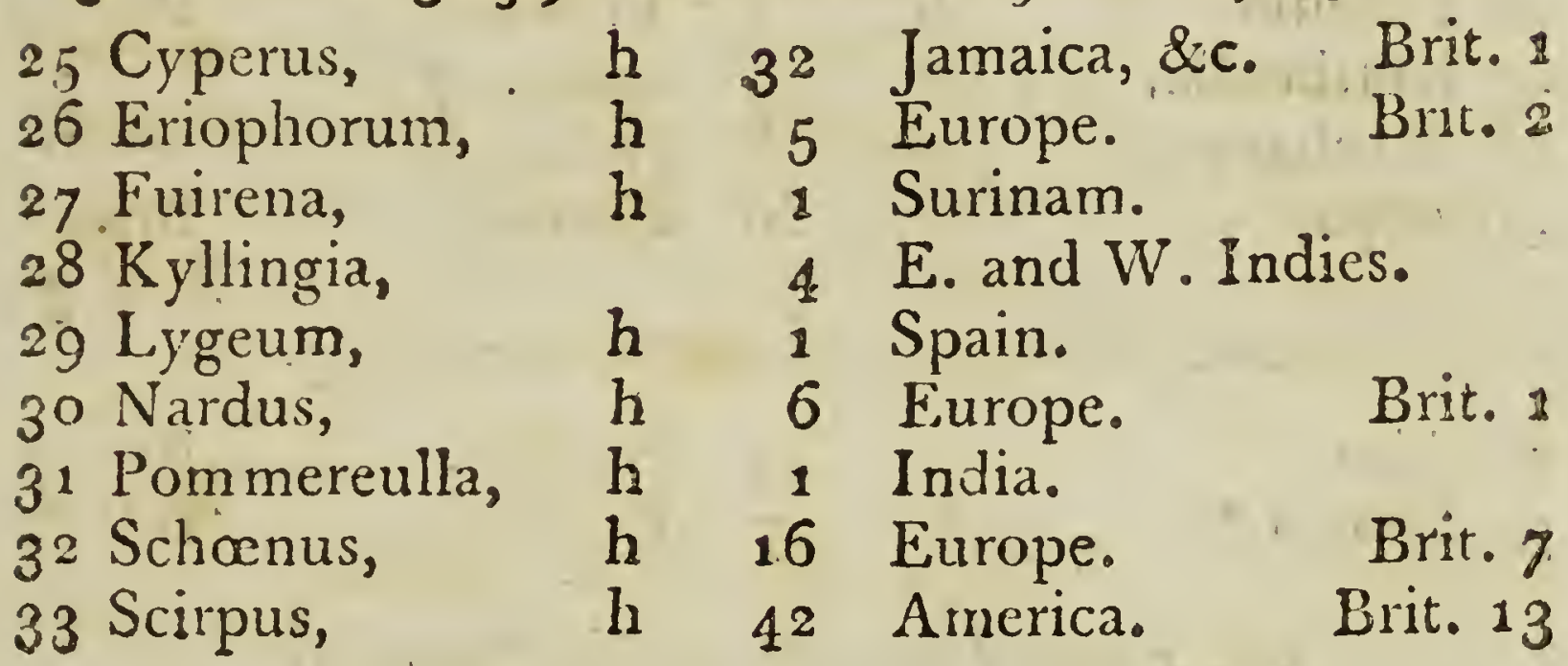

\section{OR DER II. D I G Y N I A.*}

(Two females.)

1st. Flowers one-fiower'd, straggling.

24 Agrostis,

35 Alopecurus,

36 Anthistria,

37 Arisiida,

38 Bobartia, h 25

h 6 Eirope.

1 India.

h 6 Jamaica.

$h 1$ India.

$\mathrm{H}$
Brit. 8

- Brit. 6

39 Cornucopia,

* All the plants of this ad. order, digynia, are gralses, and comprehends such the greater part; though there are some others of different character arranged in their proper clafses, as vernal grafs, $\mathcal{E}_{3} \mathrm{c}$.-Grafs is detined in be a plant, having simple leaves, a stem generally jointed and tubular, a husky calyx, (called gluma) and the seed single. The leave's are food for crutic, she small seeds for birds, and the larger grain for man. And it is observed, that nature hath so provided, that cattle (in grazing) seldom eat the flower, iotended o produce seed, unlefs compelled by hunger. 
no. genera. growth. no. of native of in Bries. 39 Cornucopix, h 2 Smyrna. 40 Dactylis, 41 Lagurus, 42 Milium, 43 Panicum, 44 Paspalum, 45 Phalaris, 46 Phleum, 47 Rottboella, 48 Saccharum, 49 Stipa,

h 5 Virginia.

h 2 Italy.

h 7 Europe. Brit. 2

h 35 India. Brit. 5

h 5 America.

h 12 Europe.

h 5 Europe.

h $\quad 5$ India.

h 10 Europe. Brit. 1 Brit. 3
Brit. 3 Brit. 3
Brit. 3

Brit. 2 Brit. 2
Brit. 5

2d. Flowers two-flower'd, straggling.

50 Aira,

51. Melica; * h 13 Europe.

h. 7 Europe.
Brit. 7

Brit. 3

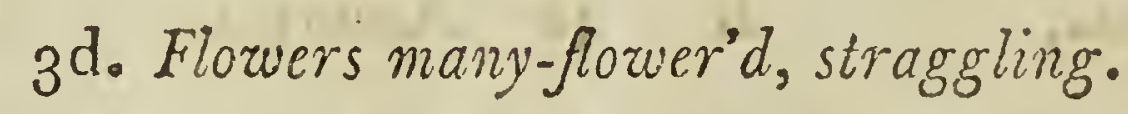

52 Avena,

53 Arundo,

54 Briza,

55 Bromus,

56 Festuca,

57 Poa,

58 Uniola, h 22 Siberia.

h 6 Europe.

h 5 Europe.

h 24 Europe.

h 17 Europe.

h 26 Europe.

h 4 Carolina:
Brit. 6

Brit. 4

Brit. 2

Brit. 10

Brit. 11

Brit. 1

4th. Flowers spikes, with receptacle awl'd.

$\begin{array}{lrrlr}59 \text { Cynosurus, } & \text { h } & 11 \text { Europe. } & \text { Brit. } 3 \\ 60 \text { Elymus, } & \text { h } & 10 & \text { Eu. America. Brit. } 3 \\ 61 \text { Hordeum, } & \text { h } & 8 & \text { Italy. } & \text { Brit. } 3\end{array}$
62 Lolium;

* In melica, the rudiment of a third floret, standing upon a litte footstalk between the other two florets, gives the efsential charafter.

+ In avena, the efsential charaeter consists in the jointed twisted aw: growing from the back of the corbila. 


\section{$T R I A N D R I A$.}

no. genera. growth. no. of native of species no. genera. Erowth. species. native of in Brit. 6. Lolium, 63 Secale, h 4 Europe. 6. Triticum, h 4 Asia. Europe. h 15 Europe. Brit. 4 Erit. 3

\section{ORDER III. TRIGYNIA.}

(Three females.)

\section{ist. Flowers beneath.}

$6_{5}$ Eriocaulon, 66 Holosteum, 67 Koenigia, 68 Lechea, 69 Minuartią, go Mollugo, 71 Montia, 72 Polycarpon, 73 Queria, 74 Triplaris, h 5 Brasils.

h. 4 Jamaica.

h 1 Iceland.

2 Canada.

h 3 Spain.

h 4 Ceylon, \&c.

h 1 Brit. 1

h 2 Italy.

l) 2 Spain.

1 America.

Brit. 1

\section{2d. Flowers above.}
75 Proserpinaca,
b
1 Virginia。 


\section{$\left[5^{2}\right]$}

\section{Class IV. T E T R A N D R I A.*}

\section{(Four stamina or males.)}

Containing three orders.

\section{ORDer I. MONOGYN I A. \\ (One female.)}

1st. Flowers one-petal'd, one-seeded, beneath.

ro. gencra. growth. no. of native of species

1 Globularia, $\& \&$ h 7 Italy.

2 Hydrophylax, i Sea shore.

3 Protea, $\quad 3^{6}$ Cape of G. Hope.

2d. Flowers onc-petai'a, one-seeded, above, aggregate.

4 Allionia, 2 America.

5 Cephalanthus; 5 a W. Indies.

6 Dipsacus, h 3 France. Brit.

7 Knautia, h 4 Archipelago.

8 Scabiosa, h 34 Italy, \&c. Brit. 3

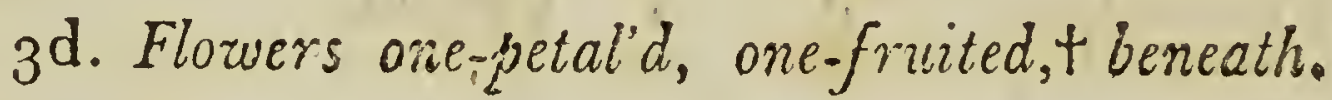

9 Egiphila,

10 Aquartia,

11 Blaria,

12 Buddleia,

13 Callicarpa,

14 Centunculus,

15 Exacum,

16 Penæa,
1 Martinico.

\& America.

s 5 Cape of G. Hope.

$s \quad 4$ W. Indies.

s 2 Virginia.

h 1

6 India.

s 8 Ethiopia.

* The stamina in this clafs being of equal length, is the distinction from the clafs didynamia, where they are two long and two short.

+ One-fruited means a single seed-vefsel undivided, containing several seeds. 


\section{TE TRANDRIA.}

no. genera. growth. no. of native of $\begin{gathered}\text { species } \\ \text { in Brit. }\end{gathered}$

17. Plantago, h 21 Europe. Brit. 6

18 Polypremum, h 1 Carolina.

19 Scoparia, .. h . 3 America.

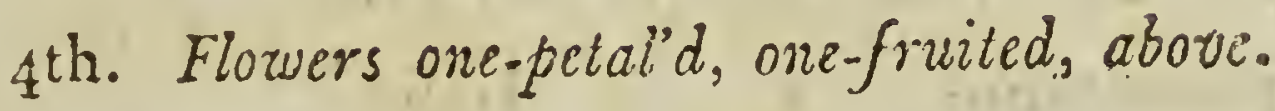

20. Catesbæa,

21 Hediotis,

22 Ixora,

23 Mannettia,

24 Mitchella,

25 Oldenlandia,

26 Pavetta,

27 Petesia,

28 Sanguisurba, ${ }^{*}$ h

$\begin{array}{crl}\text { s } & 1 & \text { Carolina. } \\ \text { s \& h } & 6 & \text { Ceylon. } \\ \text { s } & 3 & \text { India. A } \\ \text { h } & 1 & \text { Mexico. } \\ \text { s } & 1 & \text { Carolina. } \\ \text { h } & 10 & \text { America. } \\ \text { s } & 2 & \text { India. } \\ \text { s } & 2 & \text { Jamaica. } \\ \text { h } & 3 & \text { Canada. }\end{array}$

Brit. 1

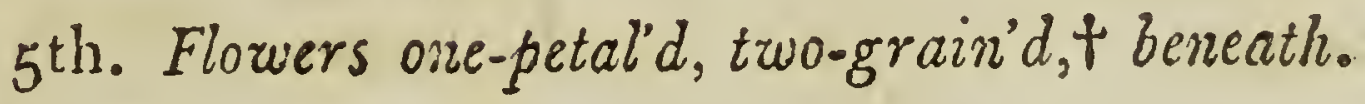

$\begin{array}{llll}29 & \text { Houstonia, } & \text { h } & 2 \\ \text { 30 Scabrita, } & \text { S } & 1 \text { Inginia. }\end{array}$

6th. Flowers one-petal'd, two-grain'd, above. siar'd. $\$$

31 Asperula,

$3^{2}$ Crucianella,

33 Diodia,

34 Galium,

35 Knoxia,

$3^{6}$ Rubia, h 10 Europe.

h 6 France. Italy.

h. 1 Virginia.

h 25 Europe.

h 1 Ceylon.

h 5 France. Italy. Brit. 1
Brit. 2

Brit. 11

37 Scherardia,

* In sanguisorba afficinalis (common wild burnet) are found small red tubercles on the root, which dyers frequently use instead of cochineal; and it is said they are also found on the roots of pimpinel!a scoxifraga, (burnet saxifrage).

+ Two-grain'd, three-grain'd, \&e. means, when the capsule is divided into two or three cells, \&ic. and a single grain or seed in each.

These are the plantre stellate of Ray, having two naked sceds, and the leaves disposed round the stem in the form of a radiant star; and are beld:o be diuretic. 
no. genera. growth. no. of native of species. $\begin{array}{llll}37 . \text { Scherardia, in } & 3 \text { Europe. } & \text { Brit. } \\ 38 \text { Spermacoce, } & \text { h } & 8 \text { Carolina. } & \end{array}$ 7th. Flowers one-petal'd, four-grain'd, beneath. 39 Siphonanthus, $s \quad 1$ India. 8th. Flowers four-petal'd, beneath.
40 Ammannia,
$\begin{array}{lll}\text { h } & 5 & \text { Jamaica. } \\ \text { h } & 4 & \text { New Holland. }\end{array}$
41 Banksia,
42 Epimedium,
h 1 Alps.
43 Fagara,
s 5 Jamaica.
44 Hartogia,
$s$.
45 Ptelea,

$S$
46 Rhacoma,
47 Samara,
s 2 America.
s 1 Jamaica.
s 1 E. Indies.

\section{9th. Flowers four-petal'd, above.}
48 Cifsus,
s 6 India.
49 Cornus,
t\& h 8 Virginia.
51 Ludwigia,
h. 2 New Caledonia.
52 Santalum,
h 3 Virginia.
53 Trapa,
$\begin{array}{lll}\text { t } & 1 & \text { India. } \\ \text { h } & 3 & \text { Europe. }\end{array}$

1oth. Flowers incomplete, beneath.

\begin{tabular}{|c|c|c|c|}
\hline 54 Alchemilla, & $\mathrm{h}$ & & Sweden. \\
\hline 55 Camphorosma, & $s$ & 5 & Spain. Italy. \\
\hline $\begin{array}{l}56 \text { Cometes, } \\
57 \text { Crameria, }\end{array}$ & h & 1 & Surat. \\
\hline 58 Dorstenia, & h & 4 & America. \\
\hline 59 Rivina, & $s$ & 4 & W. Indies. \\
\hline - Salvadora, & $\mathrm{s}$ & 1 & Persian gulf. \\
\hline ruthiola, & & & Cape. \\
\hline
\end{tabular}




\section{TE TRA N D R IA.}

11th. Flowers incomplete, above.

n20. genera. growth. no.of npecies. native of species
62 Acrena,
s 1 Mexico.
63 Elæagnus,
s 4 Spain.
64 Isnardia,
h. 1 China. America.
65 Sirium.

\section{Order II. D I G Y N I A}

(Two females.)

$\begin{array}{lllll}66 \text { Aphanes, } & \text { h } & 1 & \text { Brit. } \\ 67 \text { Bufonia, } & \text { h } & 1 & \text { Spain. America. } \\ 68 \text { Cruzita, } & & 1 & \text { Brit. } \\ 69 \text { Cuscuta, } & \text { h } & 3 & \text { Virginia. } & \text { Brit. } 1 \\ 70 \text { Gomozia, } & & \text { Granada. } & \\ 71 \text { Hamamelis, } & \text { s } & \text { Virginia. } & \\ 72 \text { Hypecoum, } & \text { h } & 1 & \text { Archipelago. }\end{array}$

\section{Order III. T E T R A G Y I A}

(Four females.)

$\begin{array}{lrrll}73 \text { Coldenia, } & \text { h } & \text { I India. } & \\ 74 \text { Ilext } & \text { t } & 3 \text { Asia. } & \text { Brit. } \\ 75 \text { Myginda, } & \text { s } & 1 \text { America. } & \\ 76 \text { Potamogeton, } & \text { h } & \text { is } & \text { Europe. } & \text { Brit. is } \\ 77 \text { Ruppia, } & \text { h } & \text { 1 } & \text { Brit. } \\ 78 \text { Sagina, } & \text { h } & 5 \text { Europe. } & \text { Brit. } 3 \\ 79 \text { Tillwa, } & \text { h } & 4 \text { Europe. } & \text { Brit. }\end{array}$

* Cuscuta (iodder). is a parasitical plant, for it decays at the root, and is afterwards nourished by the plant that supports it: it will frequently twine sound a thistle.

+ l'cx is very variable in the parts of fructification. 


\section{[.56. ]}

\section{Class V. P E N T A N D R I A.}

(Five sta nina or males.)

Containing six orders.

\section{Order.I. M O N O G Y I A.* \\ (One female.)}

1st. Flowers one-petal'd, beneath, one-seeded.

no. genera. growth. $\begin{gathered}\text { nn. of } \\ \text { species. native of }\end{gathered}$

1 Mirabilis,

h 3 Mexico.

2 Plumbago, h 4 Spain. Italy.

2d. Flowers one-petal'd, beneath, two-seeded.

Rough leaved:

3 Cerinthe, $\mathrm{h} 2$ Europe.

4 Mefserschimidia, s \& h \& Dauria.

3d. Flowers one-petal'd beneath, four-seedcd.

Rough leaved.

5 Anchusa, h 7 America. Brit. 1

6 Asperugo, h 2 Egypt. Brit. 1

7 Borago. $h \begin{aligned} & \mathrm{h} \\ & \mathrm{8}\end{aligned}$ Africa. India. Brit. 1

8 Cynoglofsum, h 9 Virọinia. Brit. 1

9 Echium, s\& h 15 Italy. \&c. Brit. 2

10. Heliotropium, h 9 Europe.

11 Lithospermum, h 8 Europe. Brit. 3

$\$ 2$ Lycopsis, $\mathrm{h} \quad 6$ Virginia. Brit. 1

13. Myosotis, h\&s 5 Virginia. Brit. 1

14 Onosma,

* The berries of the monopetalous plants of this first order, are for the most part poisonous.- The rough-leaved plants are said to he glutirous and vulnerary: they are the asperifolio of Ray, having four naked seeds. 


\section{PENTANDRIA.}

no. genera. growth. ${ }_{\text {species. }}^{\text {no. of native of in Brit. }}$ 14 Onosma, $\quad h \quad 3$ Siberia. India.

15 Pulmonaria, h 6 Siberia. Brit. 2 16 Symphytum, h 3 India. Brit.

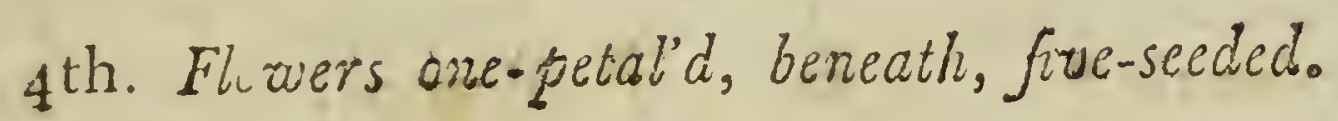
17 Nolana,

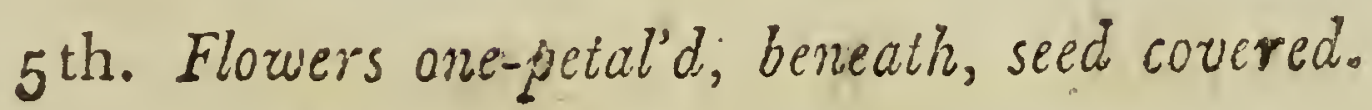

Capsules.

18 Allamanda;

19 Anagallis, 20 Androsace, 21 Aretia, 22 Azalæa; 23 Brofsian, 24 Chironia, 25 Convolvulus, 26 Coris, 27 Cortusa, 28 Cyclamen, 29 Datura, 30 Diapensia, 31 Dodecatheon, 32 Epacris, 33 Galax,

34 Hottonia, 35 Hydrophillum, h 36 Hyoscyamus, $^{*} \mathrm{~h}$ 37 I pomoea, 38. Lisianthus, 39 Lysimachia, 40 Menyanthes, 41 Nicotiana, 42 Nigrina,

h

h

h

$\mathrm{h}$

h

h

$\mathrm{h}$

h

h $\mathrm{h}$

h

h

$s$

$s$

$s$

s

h 2 India.

2 Virginia. Canada.

7 Syria.

h 21 E. \& W. Indies.

s 4 Jamaica.

h 9 Levant.

h 4 Ceylon.

$\mathrm{h} \& \mathrm{~s} 7$ America.

s $I^{1}$ Cape.
Brit. 2

Brit. 1 Brit. 1 Brit. 1: Brit. 4 Brit. 2 43 Ophiorhiza,

* The roots of hyoscyamus (henbane) are used for anodine necklaces. 
no. "genera. growth. no. of native of species.

43 Ophiorhiza, 44 Patagonula,

45 Phlox,

46 Polemonium,

47 Primula,*

48 Retzia,

49 Sheffieldia,

50 Soldanella,

51 Spigelia,

$5^{2}$ Theophrasta,

53 Verbascum, $\mathrm{h}$

$\mathrm{s}$

h 10 America.

h 5 America:

$\mathrm{h}$

\begin{tabular}{lrl} 
& 1 & Cape. \\
\hdashline & 1 & Alps. \\
h & 1 & Alps. \\
h & 2 & Marland. \\
s & 1 & America. \\
h & 12 & Italy.
\end{tabular}

Follicles.t.
54 Cameraria,
55 Ceropegia,
56 Echites,
57 Nerium,
58 Plumeria,
59 Tabernæmontanas
6o Vinca,
2 W. Indies。
4 Malabar.
15 W. Indies.
4 Ceylon.
4 W. Indies.
6 E. and W. Indies.
5 Madagascar. Brit. 2

Berries.

61 Arduina,

62 Atropa,

63 Brunsfelsia, $\$$

64 Capsicum;

65 Carifsa,

66 Cerbera,

$\begin{array}{cll}\text { s } & 1 & \text { Cape. } \\ \text { s \& h } & 6 & \text { Europe. } \\ \text { s } & 1 & \text { America. } \\ \text { h \& s } & 4 & \text { E. and W. Indies. } \\ \text { s } & 2 & \text { India. } \\ \text { s } & 3 & \text { Brasils. }\end{array}$

67 Cestrum,

* Primula weris hath three varicties, viz primula veris officinalis (cow:slip, frimula veris clatior (polyanthus,) and primula acris acaulis.

+ Sec follicle under pericarpiam; as also berry and drupe.

$\$$ Brunsfelsia, it is thought, should belong to the chars and order dingng. mia angiospermia.

+ Capsicum (Guinea pepper) hath many varieties. 


\section{PENTANDRI $\Lambda$.}

sio. genera. srowth. no. of necies. native of

67 Cestrum,

68 Chrysophyllum, $t$

69 Cordia, 70 Ehretia,

71 Ellisia,

72 Jacquinia,

73 Laugeria, .

74 Ĺycium,

75 Menais,

76 Myrsine,

77 Pæderia,

78 Physalis,

79 Randia,

8o Rauvolfia, .

81 Sideroxilon,

82 Solanum,

83 Strychnos,

84 Tournefortia, s\&h

85 Varronia,

$s$
4 W. Indies.

2 W. Indies:

6 W. Indics.

$t \quad 4$ W. Indies:

h 1 Virginia.

s\&h 3 America.

$s \quad 1$ America.

s 8 Spain. Africa.

s. 1 America.

s' 1 Africa.

s. 1 India.

h. 12 Spain.

s: 2 America.:

s 3 W. Indies.

t] 9 Eithiopia.

39 America, \&c. Brit. \&

3 India.

8 W. Indies.

6 America.

\section{Drupes.}
86 Ignatia,
87 Tektona,
h
1 India.
h. 1 Ceylon.

6th. Flowers one-petald, above.

Capsules.

88 Bellonia,

1 America.

89 Campanula, h. 62 America, \&c. Brit. 8

90 Cinchona,

S : 2 Peru.

91 Macrocneum

s 1 Jamaica.

92 Phyteuma,

6 Europe.

93 Portlandia,

94 Roclia,

$s \quad 3$ Jamaica.

25 Rondeletia, h\&s $\frac{3}{5}$ Africa.

Brit. 2 $s$ W. Indies. 
no. gcnera. growth. na. of native of species 96 Samolus, $\quad$ h 1

97 Trachelium, h 3 Italy:

Brit. 1 98 Virecta, .

Berries.

$\begin{array}{lrrl}99 \text { Chiococca, } & \text { s } & 2 & \text { Jamaica. } \\ 100 \text { Coffea, } & \text { s } & 2 & \text { Arabia. W. Indies, } \\ 101 \text { Erithalis, } & \text { s } & 1 & \text { Jamaica. } \\ 102 \text { Gardenia,... } & \text { s } & 6 \text { India. } \\ 103 \text { Genipa, } & \text { s } & 1 \text { America. } \\ 104 \text { Hamella, } & \text { s } & 1 & \text { America. } \\ 105 \text { Lonicera, } & \text { s } & 14 \text { Alps. \&c. } \\ 106 \text { Matthiola, } & \text { s } & 1 & \text { America. } \\ 107 \text { Morinda, } & \text { h } & 3 \text { America: } \\ 108 \text { Mutsænda, } & \text { s } & 3 \text { India. } \\ 109 \text { Psychotria, } & \text { h } & 4 \text { Jamaica. } \\ 110 \text { Triosteum, } & \text { h } & 2 \text { America. }\end{array}$

\section{Drupes.}

111 Scæuola,

$\$ 1$ India.

\section{7th. Flowers fue-petalid, beneath. \\ Capsules.}

112 Argophillum, It 1 New Caledonia.

113 Butneria; 2

114 Cedrela, s 1 America.

115 Claytonia, . s 3 Virginia. Sibcria.

116 Diosma, $\quad 18$ Africa, \&c.

117 Itea, $s$ irginia.

118 Roridula, $s .1$ Cape.

119 Sauvagesia; $h$ " 1 Jamaica.

Berries.

* The W. India cifoa shrub tiffers fron the Arahian in the corolla; the former having four clefts, berries many-seeded; the latter fuve cicfts, wo seeded. 


\section{PEN T A NDR I A.}

Berries.

no. genera. growth. no. of native of species 120 Aquilicia,

121 Ceano hus,

122 Celastrus,

123 Euonymus,

124 Hirtella,

125 Rhamnus, *

126 Vitis,

127 Mangifera, drupe. $t$

128 Corynocarpus. nut, $\mathrm{h}$

129 Brunia, seed 1 , s

130 Kuhnia, seed 1.s

131 Nauclea, $_{2}$ seed 1 , s
1

5: 3. America.

s 11 Virginia. Ethiopia.

s 4 Virginia. Brit. 1

s 1 Basil.

S 27 Europe. Brit. 2

8 Europe.

2 India.

1 New Zealand.

8 Africa.

1 W. Indies.

1 Oriental.

\section{8th. Flowers five-petal'd, above.}

132 Conocarpus, seed $1, s$

133 Cyrilla, capsules, s

134 Escallonia,

135 Gronovia, capsules, $h$

136 Hedera, berry, s

137 Heliconia, capsules,

138 Lagoccia, seeds $2, \mathrm{~h}$

139 Phylica, berry, s,

240 Plectronia, berry, s
3 W. Indies.

1 Carolina.

* America.

* Vera Crux.

2 Canada.

Brit.:

4 Cape.

1 Crete.

12 Cape, dre.

1 Cape.

141 Ribes, t berry, s $\left\{\begin{array}{l}\text { cirr. } \\ \text { goos. }\end{array}\right\} \begin{aligned} & 3 \\ & 6\end{aligned}$ Amer. Brit. curr. 3 $9^{\text {th. Flowers incomplete, beneath. }}$
142 Achyranthes, seed 1, s
9 India.

143 Celosia,

* From the berries of the common burkthow (rhamnus catharticuk) is made a very: fine green color, called by the French, verd-de-ve/sie, much esteemed by miniature painterș.

+ Ribes unarmed, are currants, of which there are threc species; and ribes prickly, are goosberries, of which there are six species. 
no. genera. growilh. no. of native of species.

143 Celosia, capsule, $\mathrm{h}$ 10 China.

144 Glaux, capsule, $\mathrm{h}-1$ Brit. 1

145 Illecebrum, caps.h 19 E. Indies. Brit, 1

1oth. Flowers incomplete, above.

${ }_{146} 6$ Thesium, seed $1, \mathrm{~h}: 17$ Alps, \&c. Brit. 1

$$
\begin{aligned}
& \text { Order II. D I G Y N I A. } \\
& \text { (Two females.) } \\
& \text { 1st. Flowers one-petal'd, beneath. }
\end{aligned}
$$

147 Melodinus, 'berry',

148 Porana,

149 Schrebera,

150 Steris,
1. New Caledonia,

1. E. Indies.

1 Cape.

1 Java.

\section{Follicles.*}

151 Apocynum,

152 Asclepias,

153 Cynanchum,

154 Pergularia,

155 Periploca,

156 Stapelia,t h $9 \mathrm{~N}$. America.

h 28 . France, Spain, \&c.

h 14 Spain, \&c.

s 2 . India.

$s 5$ India. Africa.

h. 5 Cape.

Capsules. h 1

h 35 Pirenean, \&c. Brit. 5 hi 1 America.

h. 5 Siberia. Brit. 1

* Sec follicle under pericarpizm.

+ Stapelia (African swallow-wort) hath a foeted odour so very like carrion, that the common flesh fly deposits its cggs on it, which are frequently hatched, but wanting proper food, dies soon after; though some have afsertcd they eat the petals of the flower, 


\section{$P E N T A N D R I A$.}

2d. Flowers five-petal'd, above.

no. genera. growth. no. of native of species. 161 Rufselia,

1 Cape.

\section{3d. Flowers five-petal'd, beneath. \\ Capsules.}

162 Anabasis, berry,s\&h 4 Spain.

163 Coprosma, herma. $\quad 2$ New Zealand.

164 Heuchera, h 1 America.

165 Linconia, $s \quad 1$ Cape.

166 Nama,

h 2 Ceylon. Jamaica.

167. Velezia,

h 1 Europe.

4th. Flowers incomplete.

168. Beta,

169 Bosea,

h

\section{$s$}

3 France.

1 Canaries.

170 Chenopodium, $h$

171 Gornphrena, h

20 Europe.

8 India.

172 Herniaria,

h\&s

173 Salsola,

174 Ulmus, $t 3$ America. h\& $\&{ }_{16} 6$ Europe.
Brit. 1

Brit. 9

Brit. 2

Brit. 2

Brit. 1

5th. Flowers five-petal'd, above, two-seeded. unbel'd.

A. With an universal and partial involucre.

175 Eryngium,

176 Hydrocotyle, $h$

177 Phyllis,
12

$s$
9 Alps.

13 America:

1 Canaries.

Brit. 2 Brit. 1

178 Sanicula,

* These are the umbellate plants of Tournefort; and it is observed, that in dry soils, they are aromatic, warm, resolvent, and carminative; but in moist places frequently poisonous. The virtue in the roots and seeds.Note, panax and arctopus (tilough umbel'd) are placed in the clafs and order polygamia dioecia, as having the charatter of that clafs and order, though they have only five stamina.-There are also a few other umbel'd plants placed in different classes, as allium, $\mathcal{E}_{c}$. 
20. genera. growth. no. of native of species species. mative of

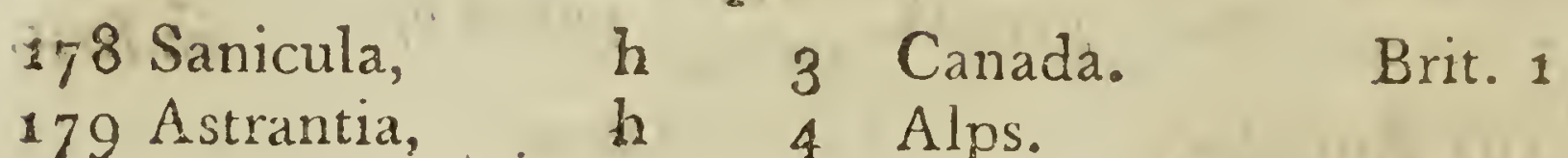
179 Astrantia, . h 4 Alps.
Flowers radiate it florets of the disc abortive. $180^{\circ}$ Artedia, 181 Caucalis, h 1 Libanus. 18. Daucus, h 6 India. 183 Echinophora, h h 6 Europe. 184 Heracieum, h 2 Apulia. 6 Siberia. Brit. 2 Brit. 1 Brit. 1 Brit. 2

Flowers radiate; florets of the radius abortize. 185 Oenanthe* h 5 Europe. Brit. 3 Flowers radiate, all fertile. 186 Tordylium, h 7 Syria. Crete. Brit. 3 Flowers fosculous ; florets of the disc abortive. 187 Laserpitium, h 11 Europe. 188 Peucedanum, h 6 Alps. Brit. 2 Fiowers flosculous, all fertile.

189 Ammi, 190 Angelica, 191 Athamanta, 192 Bubon, 193 Bunium, 194 Bupleurum, 195 Cachrys, $\mathrm{h}$ h h $\mathrm{h}$ h $\mathrm{h}$ $\mathrm{h}$

\section{Europe.}

5 Archangel.

Brit. 1

9 Sicily. Crete. Brit. 1 4 Macedunia.

1 Brit. 1 16 Fithiopia. Brit. 2 3 Sicily.

\& See radiate flowers explained in a note under the head of distinction of flowers.

* Oenanthe crncata (water dropwort) is one of the strongest vegetable poisons that is known.

t See flosculous cxplained in observation to the head of the clafs syngenesice. 
20. genera. groutin. ino. of native of spocies no. specics. in Brit. 196 Conium,

h 4 Africa.

197 Crythmum; h

198 Cuminum, h

199 Ferula, * h 200 Haselquistia, $h$ 201 Ligusticum,

202 Selinum, 203 Sison, 204 Sium, Pyrenean. Brit. 1 Brit. 1 1 Egypt.

9 Europe. Canada. 2 Egypt.

7 Austria. Brit. 2 h 5 Germany: Brit. i h 7 Canada. Brit. 4 h 10 Sicily. Brit. 3

B. With only partial involucres; no universal. Flowers subradiate, all fertile. 205 Ethusa, h 3 Europe. Brit.2 Flowers radiate: floreis of the disc abortioe. $\begin{array}{llll}206 \text { Coriandrum, } & \text { h } 2 \text { Italy. } & \text { Brit. } \\ 207 \text { Scandix, } & \text { h } 10 \text { Europe. } & \text { Brit. } 4\end{array}$ Flowers flosculous, all fertile.

$\begin{array}{llrll}208 \text { Cicuta, } & \text { h } & 3 \text { Canada. } & \text { Brit. } 1 \\ 209 \text { Imperatoria, } & \text { h } & \text { Alps. } & \text { Brit. } 1 \\ 210 \text { Phellandrium, } & \text { h } & 2 \text { Europe. } & \text { Brit. } 1 \\ 211 \text { Seseli, } & \text { h } & 11 \text { Europe. } & \end{array}$

Flowers flosculous; florets of the disc abortive.

212 Chærophyllum, h 8 Europe. Brit.

C. With no involucre; neither universal nor partial. Flowers flosculous; florets of the disc abortive.
213 Carum,
h 1. Europe.
214 Smyrnium,
h $K^{5 \text { Egypt. }}$
Brit. 1
Brit. 1
Flowers

* The drug asafretida, is a gum resin of feralla asafatida. 


\section{Flowers flosculous, all fertile.}

no. genera. growth. no. of native of species.

215 Anethum,*

216 Apium,

217 Aigopodium, $h$

218 Pastinaca, $\$ \quad h$

219 Pimpinella, $h$

220 Thapsia, $h$

221 Cufsonia, $\left\{\begin{array}{c}5 \text { petals } \\ 3 \text { corner'd }\end{array}\right\}$ h 2 Cape.

\section{ORDER III. T R I G Y N I A, \\ (Three females.)}

1st. Flowers above, five-cleft.
Brit. i Brit. 1 Brit. 1 Brit. 1 Brit. 3

222 Scambucus, t\&h 4 Canada. Brit. 2 2d. Flowers beneath.

224 Basella, 225 Pharnaceum, h 226 Xylophylla,

$$
\begin{array}{rrl}
\text { h } & 3 & \text { India. } \\
\text { h } & 13 & \text { Asia. Africa. } \\
& 2 &
\end{array}
$$

Corols five-petal'd.

227 Alsine, $\$$ 228 Cafsine, h

$s$
3 France.

5 Ethiopia. Carolina.

* Anethum, (fennel and dill). Note, fennel only differs from dill, in the seeds not being bordered at the cdge like those of dill.

\pm Celery (a species of apium) called apium dulce by other authors, not described by Linnæus. The universal involucre is often wanting.

$\$$ The gum resin called opoponax, is from the pastinaca opoponax.

II Aniseds are from a species of pimpinella'(pimpinclia anisum).

+ In alsine (the common chickweed) the stamina soon fall off, so that whe flowers frequently appear with fewer than five. The young shoots and leaves, when boiled, are said to be very like spring spinach, and equally wholesome, 


\section{$P E N T A N D R I A$.}

no. genera. growth. $\begin{gathered}\text { no. of necies. naive of in Brit. } \\ \text { species }\end{gathered}$

229 Corrigiola,

230 Drypis,

231 Rhus,*

$23^{2}$ Sarothra,

233 Semecarpus,

234 Staphylea,

235 Spathelia,

$23^{6}$ Tamarix,

237 Telephium,

238 Turnera, h 1 France.

h 1 Italy.

s 24 Italy. Spain. America.

h 1 Virginia.

h 1 India.

s 2 Virginia.

1 Jamaica.

S 2 France. Germany.

h 2 France. Italy.

s 4 Jamaica.

Order IV. TE T R A G Y I A:

(Four females.)

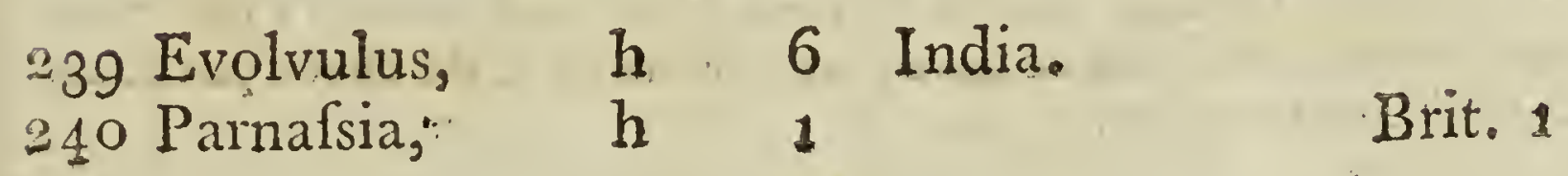

Order V. PENT A G Y N IA.

(Five females.)

1st. Flowers above.

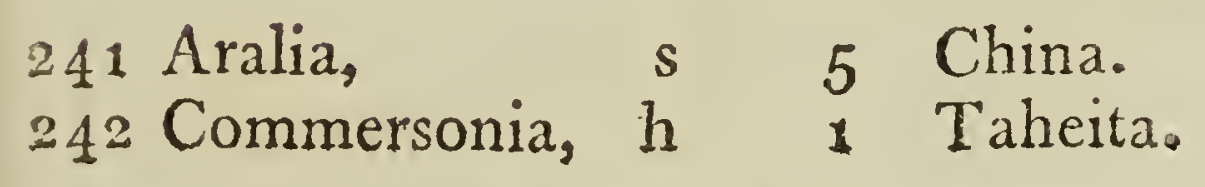

2d. Flowers beneath.

243 Crafsula, 244 Gisekia, 245 Stätice,

h 53 Ethiopia, \&C.

h 1 E. Indies.

h 21 America, Brit. 3

$\mathrm{K}_{2} \quad$ Corols

* The resin called gum copal, is from rhus copallinun; and the rhus cori aria was formerly much used for tanning leather. 


\section{Corols five-petal'd.}

no. genera. growth. no. of native of species. 246 Androvanda, h 1 Italy. India. 247 Drosera, $*$ h 8 India. Brit. 3 248 Linum, h 22 Alps. Aust, Virg. Brit. 5 249 Mahernia, s 2 Cape. 250 Sibbaldia, It 3 Siberia. Brit. 1

\section{Order VI. P O L Y G Y N I A.} (Many females.)

251 Myosurus, h 1 Brit.

* Sun-dew (drosera) derives its name from small drops of a liquor like dew, hanging on its fringed leaves, and continuing in the hottest part of the dxy, exposed to the sun. 


\section{[ 69 ]}

\section{Class VI. H EX A N D I A.*}

(Six stamina or males.)

Containing five orders.

\section{OrDER I. M O NOGYNIA。}

\section{(One female.)}

1st. Flowers calycled, $\uparrow$ furnished with calyx and corollew.

Corols one-petal'd.

no. genera. growth. no. of necies. native of species
1 Duroia,
t " I Surinam.

Corols three-petal'd, or three-parted.

$\begin{array}{llll}\text { 2. Bromelia, } & \text { h } & 7 \text { W. Indies. } \\ \text { 3 Burmannia, } & \text { h } & 2 & \text { Ceylon. } \\ 4 \text { Bursera, } & \text { s } & 1 & \text { W. Indies. } \\ \text { 5 Tillandsia, } & \text { h } & 9 & \text { America. } \\ \text { 6 Tradescantia, } & \text { h } & 8 & \text { Virginia. }\end{array}$

Corols five-petald d.

7 Frankenia,

Corols six-petal'd, or six-clefi.

$\begin{array}{lrll}8 \text { Berberis, } & \text { s } & 3 & \text { Cretc. } \\ 9 \text { Canarina, } & \text { s } & 1 & \text { Canaries. } \\ 10 \text { Capura, } & \text { s } & 1 & \text { India. } \\ 1 . \text { Hillia, } & \text { s } & 1 & \text { America. } \\ 12 \text { Leontice, } & \text { h } & 4 \text { Greece. }\end{array}$

13 Loranthus,

* The stamine in this clafs being of equal length, is the distintion from the clafs tetradynamia, where the stamina are four long and two short.'The bulbous roots in this clals are some of them noxious, as drffodil, hyacinth, fritillary, $\mathcal{E}^{2}$. others are corrosive, as garlic, $\mathcal{E} c_{\text {. but by }}$ roasting or boiling they lose great part of their acrimony.

t The calyx in some genera is only a rim or border. 
no. genera. growth. no. of native of species.
13 Loranthus,
s 11 China. Europe.
14 Prinos,
15 Richardia,
s 2 America.
h 1. Verä Crux.

\section{Corols twelve-cleft.}

16 Achras, $\quad$ t 4 W. Indies.

2d. Flowers spathed, or glumed.

27 Ehrharta, h 1 Africa.

Corols above, six-petal'd, or six-cleft.
18 Amaryllis,
h 1.3 Spain. Italy.
19. Crinum,
h 10 Africa. America.
20 Galanthus, h 1
21 Hæmanthus,
h
5 Guinea.
22 Hypoxis,
23 Leucojum,
24 Narcilsus,
25 Pancratium,
26 Pontederia,
h 12 Virginia, \&c.
h 3 Germany.
h 14 Eastern. Brit. 2
h 7. Ceylon. Mexico.
h 5 Malabar.
Brit. 1

27 Allium, *

28 Aphyllanthes,

29 Bulbocodium,

$3^{\circ}$ Tulbagia,
Corols beneath, six-petal'd. h 40 . Europe.

h. 1 Montpelier.

h 1 Spain.

h 2 Cape.

\section{3 d. Flowers naked (without calyx).}

Brit. 7

Brit. 1 31 Phorrnium,

$\underline{\mathrm{h}}$

Corols

* The apparent difference of the onion (allium cepa) from garlic, is the swelling pipy stalk of the former, being thicker in the middle than at eithe end. 
Corols above, six-petald, or six-cleft.

no. genera. growth. $\begin{gathered}\text { no. of native of species } \\ \text { species. }\end{gathered}$

$\begin{array}{llll}32 \text { Agare, } & \text { h } & 4 & \text { America. } \\ 33 \text { Alstroemeria, } & \text { h } & 5 & \text { Italy. Peru. } \\ 34 \text { Gethyllis, } & \text { h } & 4 \text { Cape. }\end{array}$

Corols beneath, six-petal'd, or six-cleft.

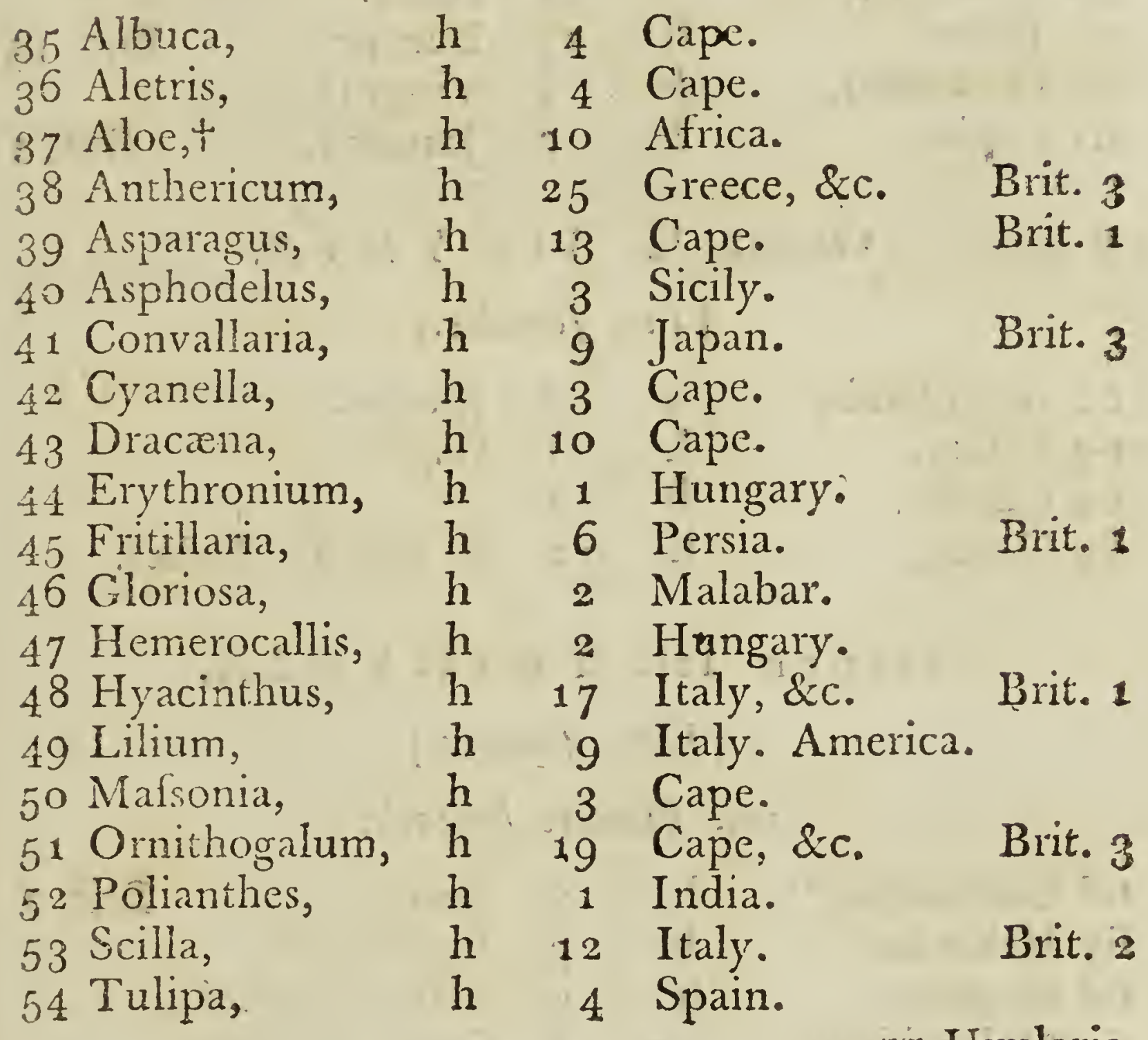

55 Uvularia,

* The flower stems in some of the species of american aloe (agave) rise to. the height of above 20 feet: they are generally many years before they flower, but this greatly depends on the health of the plant, and heat of the climate: the flower stem rises from the center of the radical leaves, which are closely folded over each other, and until they are fully expanded, the stem cannot advance. It continues in flower by succefsion, 2 or 3 months; and then the whole plant dies.

i The succotrine aloe is a gum resin from the aloe perfoliata; and the he* patic or horse aloe, is supposed to be a coarscr sort from the same species. 
no. genera. growth. no. of native of species. $\begin{array}{lrr}55 \text { Uvularia, } & \text { h } & 3 \text { Bohemia. } \\ 56 \text { Yucca, } & \text { s } & 4 \text { America. }\end{array}$

4th. Flowers incomplete.

$\begin{array}{llrlr}57 \text { Acorus, } & \text { h } & \text { 1 Holland. } & \text { Brit. } 1 \\ 58 \text { Calamus, } & \text { h } & \text { 1 India. } & \\ 59 \text { Juncus, } & \text { h } & 23 & \text { Europe. } & \text { Brit. } 15 \\ 60 \text { Orontium, } & \text { h } & \text { 1 Virginia. } & \\ 61 \text { Peplis, } & \text { h } & 2 \text { Jamaica. } & \text { Brit. } 1\end{array}$

\section{Order II. D I G Y N I A.}

(Two females.)
62. Atraphaxis,
63 Falkia, 64 Ghania, 65 Oryza,

$\begin{array}{lll}\text { s } & 2 & \text { Medea. } \\ \text { h } & 1 & \text { Cape. } \\ \text { h } & 1 & \\ \text { h } & 1 & \text { E. and W. Indies. }\end{array}$

\section{Order III. T R I G Y N I A. (Three females.)}

1st. Flowers beneati.

66 Colchicum, * h 3 Spain. Brit. 67 Helonias, 68 Medeola, h 3 Pensilvania. 69 Melanthium, h. 8 Cape. America. 7o Rumex, h\&s 33 Egypt, \&c. Brit. 18 71 Scheuchzeria, h 1 Helvetia. 72 Triglochin, h 3 Europe. Brit. 2 73 Trillium, h, 3 Canada.

* The hermodactyl of the shops, is supposed to be the root of a specics of colchucum, called colchicum varigatum. 
no. genera. growth. no. of native of species. $\begin{gathered}\text { species } \\ \text { in Brit. }\end{gathered}$ 2d. Flowers above.

74 Flagellaria, $s \quad 1$ Java.

$$
\text { Order IV. TE T R A G Y N I A }
$$

(Four ferwales.)

75 Petiveria,

$s 2$ W. Indies.

Order V. POLYGYNIA.

(Many females.)

76 Alisma,

h 8 Europe.

Brit. 3 


\section{[ 74 ]}

\section{Class VH. H EPT A N D R I A.}

(Seven stamina or males.)

Containing four orders.

$$
\begin{gathered}
\text { Order I. MONOGYN I A. } \\
\text { (One female.) }
\end{gathered}
$$

no. genera. srowth. no. of native of

species in Brit.

1 Esculus,

2 Disandra,

I 2 Asia. America.

3 Trientalis,

Order II. D I G Y N I A

(Two females.)

4 Limeum,

h 2 Africa,

Order III. T E T R A G Y I $\Lambda$ 。

(Four females.)

5 Aponogeton,

6 Saururus,

2 E. Indies.

h 2 Virginia.

\section{Order IV. HE P T A G I I .}

(Seven females.)

7. Septas,

l. 1 Capc。 


\section{[ 75 ]}

\section{Class VIII. O C T A N D R I A.}

(Eight stamina or males.)

Containing four orders.

Order I. MONOG Y N IA.

(One female.)

1 st. Flowers complete.

Corols oncepetal'd.

no. genera. grawth. no. of native of species. $\begin{gathered}\text { species } \\ \text { in Brit. }\end{gathered}$

1 Erica,

2 Vaccinium,

s 74 Many places. Brit. 4 s 12 Europe. Brit. 4

Corols four-petal'd.

3 Allophyllus,

4 Amyris,

5 Anticorus,

6 Combretum,

7 Epilobium,

8 Gaura,

9 Grislea,

10 Guarea,

11 Jambolifera,

12 Lawsonia,

13 Melicocca,

14 Menecylon,

15 Enothera,

16 Ophira,

17 Osbeckia,

18 Rhexia,

19 Ximenia, s, : 1 Ceylon.

s 9 Carolina.

s 1 Arabia.

$s \quad 2$ America.

h 7 Alps.

h 1 Virginia.

s 1 America.

s 1 Brasils.

$s \quad 1$ "India.

s 3 Egypt. India.

$s \quad 1$ America.

s 1 Ceylon.

h 10 America.

$s \quad 1$ Africa.

2 Ceylon. China.

h 5 Virginia.

s. 2 America.

I. 2
Brit. y

Corols 
20. genera. growth. $\begin{gathered}\text { no. of } \\ \text { species. native of species }\end{gathered}$ Corols frve-petal'd.

20 Backia,

21 Tropæolum,

$\begin{array}{lll}\text { s } & 1 & \text { China. } \\ \text { h } & 4 & \text { Peru. }\end{array}$

Corols eight-petals, or eighi-cleft.

22 Chlora, 23 Fuschia, 24 Mimusops,

$\begin{array}{lll}\mathrm{h} & 4 & \text { Italy. } \\ \mathrm{h} & 3 & \text { America. } \\ \mathrm{s} & \mathbf{2} & \text { India. }\end{array}$

2d. Flowers incomplete. Calyx four-leaves, or four-cleft.

25 Daphne, 26 Dodonæa, 27 Gnidia, 28 Lachnæa, 29 Pafserina, 3 o Stellera, 31 Dirca, no calyx, $t \quad 1$ Virginia.

\section{Order II. D I G Y N I A.}

(Two females.)

Corols four-petal'd.

32 Codia,

33 Moehringia,

34 Schmiedelia,

35 Weinmannia, s

36 Galenia, cor. none, s
1 Mountains.

1 Alps.

1 E. Indies.

4 Jamaica.

2 Africa.

\section{OR DER III. T R I G Y N I A}

$$
\text { (Three females.) }
$$

$$
\text { Corols four-petal'd. }
$$

\section{Cardiospermum, $s 2$ America.}


20. genera. growth no. of native of species. 38 Paullinia, $s \quad 14$ E. and W. Indies. 39 Sapindus, $\quad t \quad 4$ E. and W. Indies.

Corols none.

40 Coccoloba, $t \quad 7$ Barbadoes.

4.1 Polygonum, ${ }^{*}$ h 27 Amcrica. Brit. 10

ORder IV. TE T R A GY NIA.

(Four females.)

Corols four-petal'd.

$\begin{array}{lllll}\text { 42 Elatine, } & \text { h } & \text { 2 } & \text { France. } & \text { Brit. } \\ 43 \text { Haloragis, } & \text { h } & 1 & \text { New Caledonia. } & \\ 44 \text { Paris, } & \text { h } & 1 & \text { Brit. } \\ 45 \text { Adoxa, 4or 5cleft, h } & 1 & \text { Brit. 1 }\end{array}$

* The root of polygonun bistorta (bistort) is one of the strongest vegetable bitters.-See tormentilla. 


\section{$\left[\begin{array}{ll}7^{8} & ]\end{array}\right.$}

\section{Class IX. EN NEA N D R I A.}

(Nine stamina or males.)

Containing three orders.

\section{ORDER I. MONOGYNI $A$.}

(One female.)

no. genera. growth, no. of native of species.

1 Anacardium,

2 Cafsyta,

3 Laurus, *

4 Tinus, $t \quad 1$ W. Indies:

2 India.

S 12 India. Persia.

$S \quad 1$

Order II. T:R I G Y N I A . (Three females.)

5 Rheum,

h 6 China. Asia.

\section{Order III. H E X A G Y N I A.}

(Six females.)

6 Butomus,

h 1

Brit. $x$

* The true cinnamon is the bark of the laurus cimnamomum; and the base cinnamon, which is often sold for the true, is the bark of the laurus cajsia.The drug camphor is obtained from another specics of laurus, called laurus camphora.-Laurus benzoin from Sumatra, is said to be the true benzoin of the shops. Phil. Soci. at Haurlem. 


\title{
[ 79$]$
}

Class X. D E C A N R I .

(Ten stamina or males.)

Containing five orders.

\author{
Order I. MONOGYNIA. \\ (One fernale.)
}

1st. Flowers many-petal'd, irreguiar.

no. genera. growth. npecies. native of species

1 Anagyris,

2 Bauhinia,

3 Cæsalpinia,

1 Cafsia,

5 Cercis,

6 Dietamnus, *

7 Guilandina,

8 Hymenæa,

9 Myroxylon,

10 Parkinsonia,

11 Poinciana.

12 Sophora,

13 Toluifera.t. s 1 Italy.

$s$ 8: E. and W. Indies.

t 3 W. Indies.

s\& h 37 E. and W. Indies.

s 2 Italy. Canada.

h 2 Cape. Germany.

$s \quad 5$ E. and W. Indies.

$t \quad 1$ W. Indies.

1 Peru.

t 1 W. Indies.

$s \quad 3$ E. and W. Indies.

s 13 Levant, \&c.

2d. Flowers many-petal'd, equal.

14 Adenanthera, $\cdots t 2$ India.

${ }_{15}$ Chalcas,

* The atmosphere which floats around the fraxinella (dictamnus albus) is inflammable, supposed to arise from an admixture of some efsential oil.

+ On the Malabar Coast, the roots of guilandina moringa are scraped and used as horse-radish, and have much the same taste.

$\$$ The resin called gum anime is from hymenca courbaril.

$\|$ Flower fence, (poinciana) is so called, because they make fenees with it in Barbadoes to divide land: it hath a beautiful flower, and is armed with spines.

\$ The balsam of tolu is from toluifera balsamum. 
no. genera. growth. no. of native of species.

15 Chalcas,

16 Clethra,

17 Cynometra,

18 Dionæa,

10. Fagonia,

20 Guajacum, *

21 Hematoxylon,

22 Heisteria,

23 Jutsicua,

24 Ledum,

$\simeq 5$ Limonia,

26 Melastoma,

27 Melia,

28 Monotropa,

29 Murraya,

3o Prosopis,

31 Pyrola,

32 Qualsia,t

33 Quisqualis,

34 Ruta,

35 Swietenia,

$3^{6}$ Thryallis,

37 Tribulus,

38 Trichilia,

39 Turraa,

\&o Zigophillum, h \& s

\section{$\mathrm{s}$}

$s$

S

$s$

h

$t$

$t$

$S$

$S$

$s$

$s$

$s$

$t$

h

$s$

$s$

h

s

s

$s$

$t$

$s$

h

$s$

$s$
1 India.

1 Carolina.

2 India.

1 Carolina.

3 Crete. Spain. Arabia.

3 W. Indies. Africa.

1 Campechy.

1 Martinico.

6 Lima. India.

1 Europe.

3 India.

15 Amcrica.

2 Syria Spain.

2 Canada.

Brit. 1

1. E. Indies.

1 India.

6 Europe.

2 Surinam.

1 India.

5 Patavia. Europe.

1 America.

1 Brasil.

4 Jamaica. France.

3 Jamaica.

1 E. Indies.

11 Syria.

3d. Flowers

it Gum guajacum is from guajacum officinale.

+ Quafsia is said properly to helong to dioecin decandria.

This seems to be the same plant mentioned by Virgil, under the name of tribulus. It is called in English, caltrops, from the form of the fruit resembling those instruments of war, strewed in the enemies' way to annoy their horscs. It is a trouhlesome weed amongst the corn in some parts of France and Spain, annoying the feet of the cattle with jis streng prickles. The species is tribulus terrestriso 


\section{E C $A N D R I A$.}

no. gencra. growth. no. of native of in Brites. 3 d. Flowers onc-petal'd, equal.

41 Andromeda,

42 Arbutus,

43 Codon,

44 Epigxa,

45 Gaultheria,

46 Inocarpus,

47 Kalmia,

48 Rhododendron, s

49 Siyrax,
15 Alps. Lapland. Brit. 2

10 Acadia. Brit. 3

1 Royen.

1 Virginia.

1 Canada.

1 Taheite.

2 Virginia.

7 Alps.

1 Italy.

4th. Flowers without petals, or incomplele.

\section{Bucida,}

51 Copaifera, *

52 Dais,

53 Samyda,

$\begin{array}{lll}\text { s } & 1 & \text { Jamaica. } \\ s & 1 & \text { Brasil. Antillas. } \\ s & 2 & \text { Cape. } \\ s & 5 & \text { W. Indies. }\end{array}$

\section{Order II. D I G Y N I A}

(Two females.)

Corols none.

$\begin{array}{llll}54 \text { Chrysosplenium, h } & 2 \text { Germany. } & \text { Brit. 2 } \\ 55 \text { Scleranthus, h } & 3 \text { Germany. } & \text { Brit. 2 } \\ 56 \text { Trianthema, h } & 3 \text { Jamaica. } & \end{array}$

\section{Corols one-petal'd.}
57 Royena,
s 5 Cape.

Corols frue-petal'd.

58 Cunonia, 59 Dianthus,

$s$ Cape.

h\&s 21 Alps. China. Brit. 6 $\mathrm{M}$ 6o Gypsophila,

* Balsam capaibi is from capaifera officinalis.

+ Formerly only those plants with broader leaves were called sweet Wit liam (under dianthus barbatus); and those with narrower leaves were called sweet John. 
no. genera. growth. $\begin{gathered}\text { no. of native of species. } \\ \text { in Brie. }\end{gathered}$ 6o Gypsophila, h 10 France. Spain. 61 Hydrangea, h 1 Virginia. 62 Mitella, $\mathrm{h} 2$ America. 6.3 Saponaria, h 8 Crete. Brit. 1. 6t Saxifraga, h 39 America, \&c. Brit. 9 65 Tiarella, h 2 America.

\section{Order III. T R I G Y N I A.}

(Three females.)

66 Banisteria, s 7 W. Indies.

67 Erythroxylon, dru.s 2 Jamaica.

68 Graridella, h 1 Italy.

69 Malpighia, berry, t 9 W. Indies.

70 Triopteris, s 1 Jamaica.

Capsules one-cell'd.

$\begin{array}{llrll}71 \text { Arenaria, } & \text { h } & 26 & \text { Bavaria, \&c. } & \text { Brit. } 8 \\ 72 \text { Stellaria, } & \text { h } & 8 & \text { Europe. } & \text { Brit. } 3\end{array}$

Capsules three-cell'd.

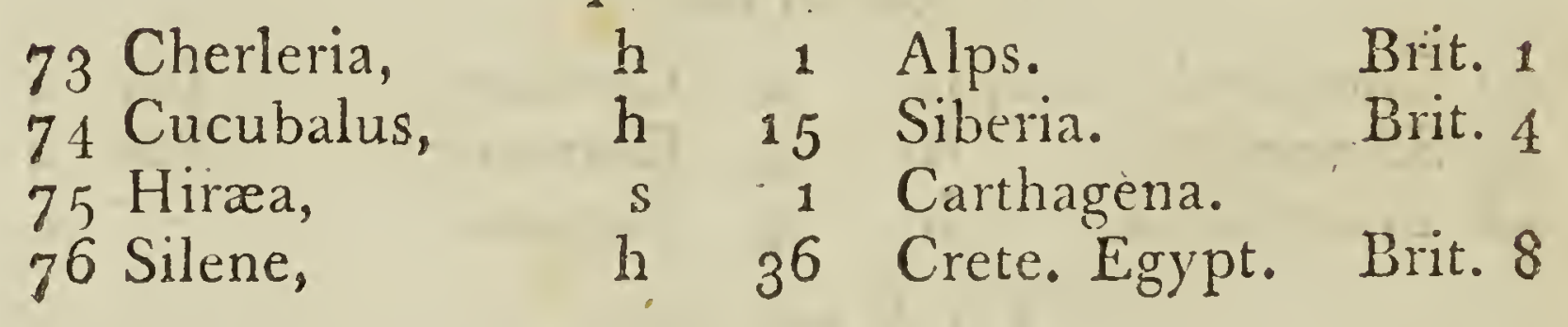

\section{Order IV. PEN T A G Y I A.}

(Five females.)

77 Agrostemma, h 4 Europe. Brit. 1

78 1verrhoa, $s=3$ India.

79 Bergia. $\quad h \quad 2$ Cape.

8: Cerastium, h 16 Alps. Brit. 8

81 Coryledon, h 13 Cape. Siberia. Brit. 2

82 Forskihlea, h 2 , Cape.

83 Grielum, s 1 Ethiopia. 


\section{E C A N D R I A.}

no. genera. growth. $\begin{aligned} & \text { no. of native of species. } \\ & \text { in Brit. }\end{aligned}$

84 Lychnis,

85 Oxalis,

86 Penthorum,

87 Sedum,

88 Spergula,

89 Spondias,

9o Suriana, h 9 Siberia.

h 22 Africa. America. Brit. 1

h 1 Virginia.

h 8 Europe.

h 5 Europe.

$t \quad 2$ W. Indies.

s 1 W. Indies.
Brit. 8

Brit. 4
Brit. 3
Order V. DEC A G Y I A.

(Ten females.

91 Neurada,

92 Phytolacca, h 1 Egypt. Arabia. h 4 America.

Crass 


\section{Class XI. DO D ECA N D RIA.}

\section{(Twelve stamina or males.)}

This clafs, although its title is exprefsive of twelve stamina only; consists of such plants as are furnished with any number of stamina from eleven to nineteen. inclusive. And it is also to be observed, that in this clafs the stamina are fixed to the receptacle, but in the next clals they are fixed to the calyx or corolla.

This clafs contains five orders.

$$
\begin{gathered}
\text { Order I. MONOGYN I A. } \\
\text { (One female.) }
\end{gathered}
$$

no. genera. growth. no. of native of species.

Corols none,
1 Asarum,
h
3 Canada.
Brit. 1
2 Bocconia,
3 Hudsonia,

$s \quad 1$ Jamaica.

Corols four-petald, or four-cleft.

$\begin{array}{llll}4 \text { Cratreva, } & \mathrm{t} & 3 & \text { Indies. } \\ 5 \text { Garcinia, } & \mathrm{t} & 3 & \text { E. Indics. } \\ 6 \text { Halesia, } & \mathrm{s} & 2 & \text { Carolina. } \\ 7 \text { Rhizophora, } & \mathrm{s} & 7 & \text { India. }\end{array}$

Corols

OBs. The reason of the chasm in the clafses from ten to twelve stamina, is, that no flowers have yet been found with only cleven, so as to form a clifs. Reseda hath sometimes only eleven, but ofter more, yet never cxceeding fiftecn.

* Rhizophora (mangrove or mangles) is called the kandel or candle of the Indians, because the wood, which is rery solid and heavy, makes the clearest, most ardent, and durable fire, of any other materials. 


\section{O D E C A N D R I A.}

no. genera. growth. no. of necies. native of in Brit.

Corols five-petal'd.

8 Dodecas,

9 Nitraria,

10 Peganum,

11 Portulaca,

12 Triumfetta,

13 Vatica,

14 Winterania, *

15 Blakea,

16 Ginora,

17 Lythrum,

18 Gethyllis,

19 Befaria,

20 Bafsia,

21 Decumaria,
1 Sirrinam.

s. 1 Volga.

h 2 Afsyria.

h. 9' Europe. America.

s 4 Indics.

s 1 China.

t 1 America.

Corols six-petal'd.

$\begin{array}{lll}\mathrm{s} & 2 & \text { Jamaica. } \\ \mathrm{s} & 1 & \text { America. }\end{array}$

h. 15 America. Brit. 2

h. 1 Africa.

Corols seven-petald.

h 2 New Granada.

Corols eight-clefi.

In 1 Malabar.

Corois ten-petal'd.

$$
\text { Order II. D I G Y N I A. }
$$

(Two females.)

22 Agrimonia, h 4 Europe. Brit.

23 Heliocarpus, $t \quad 1$ America.

\section{Order III. TR I G Y N I A.}

(Three females.)

24 Euphorbia, h 64 Canaries, \&c. Brit. 11 25 Pallasia, 
no. genera. growth. no.nf nativecies. of species

25 Pallasia,

26 Reseda,

27 Tacca,

28 Visnea,
1 Caspian Sea.

h 12 France. Brit.

1. E. Indies. Taheite.

1 Canaries.

\section{ORDER IV. PENT A G Y I A.}

$$
\text { (Five females.) }
$$

29 Glinus, h 2 Spain.

Order V. D O D E C G Y I A.

(Twelve females.)

3o Sempervivum, h\&s 8 Canaries.

Brit. 1 


\section{$\left[\begin{array}{lll}{[87} & \end{array}\right.$}

\section{CLASS XII. I C O S A N D R I A.}

\section{(Twenty stamina or males.)}

The plants of this clafs furnisheth most of the eatable fruits in esteen; none are noxious except the cherry-laurcl. The flowers bear the following character:

1st. A calyx of one leaf, and concave.

$2 d$. The coroila fastened by its claws into the inner side of the calyx.*

$3^{d}$ The stamina, twenty or more, inserted also into the inner side of the caly'x or corolla.

$\mathrm{O}_{3 \mathrm{~s}}$. As the number of stamina in this clafs is not limited, great attention must be had to the above character, to distinguish it from the next clafs (polyandria), where the stamina are inserted into the receptacle.

This clafs contains five orders.

\section{Order I. MONO G Y I A.}

$$
\text { (One female.) }
$$

:30. genera. growth. no of native of species. Calyx above.

I Cactus, ${ }^{+}$ s 24 W. Indies. Mexico. 2 Eugenia,

* When the corolla is inserted into the calyx, it always consists of many petals; and the calyx, of one leaf.

+ The cochineal animals are supported on aspecies of the cactus, ealled cactus cochenillifer. - The flower of the cactus grandiflora (one of the creeping cereuses) is said to be as grand and bealtiful as any in the vegetable system: It hegins to open in the evening about seven o'clock, is in perfection about eleven, and fades about four in the morning, so that the same flower only continues in perfection about six hour's. The calyx when expanded is sbout a foot in diameter, of a splendid jellow within, and a dark brown 
no. genera. growth. no. of native of species
2 Eugenia,
s 7 Malacca. India.
3 Myrtus,
4. Philadelphus,
13 Europe. Asia.
5 Psidium,
6. Punica*
2 Verona. Carolina.
3 E. and W. Indies.
2 Spain, \&c.

Calyx beneath.
7 Amygdalus,
8 Chrysobalanus,
9 Plinia, .
4 Persia. Jordan.
1 America.
3 Surinam.
10 Prunus,
t $15\left\{\begin{array}{l}\text { America. Siberia. } \\ \text { Armeniaca. }\end{array}\right.$
11 Sonneraitia,
1 New Guinea.

Brit. 6

\section{Order II. D I G Y N I $A$.}

(Two females.)

12 Cratagus, s 10 India.

Brit. 3

\section{ORDER III. T R I G Y I A.}

(Three females.)

13 Sesuvium,
11 Sorbus,

$\begin{array}{lll}s & 1 & \text { India. } \\ t & 3 & \text { Europe. }\end{array}$

Brit. 3

$$
\text { Order. IX. PENT A G Y I A. }
$$

(Five females.)

Calyx above.

15 Mesembryanthemum, 51 Africa, \&c.

16 Mespilus,

without; the petals are many, and of a pure white; and the great number of recurved stamina, surrounding the style in the center of the flower, make a grand appearance, to which may be added the fine scent, which perfumes the air to a considerable distance. It flowers in July.

* The balanstines of the shops are the calyx and corolla of the double flowering pomegranates (punica). 


\section{COS A N D I A.}

no. genera. growth. no. of native of species sibecies.

16 Mespilus,

17 Pyrus,

18 Tetragonia, s\&b 5 Ethiopia.

Calyx beneath.

19 Aizoon,

20 Spirca,

h 10 Canaries.

s \& h 19 Japan. s 9 Canada.

$t \quad 11$ Cydonia.

Brit. 1

Brit. 2

ORDER V. POLYG Y I A

(Many females.)

Calyx five-cleft.

21 Rosa,

22 Rubus,

Brit. 2

$\begin{array}{llll}s & 18 & \text { France. } & \text { Brit. } 5 \\ s & 14 \text { India. } & \text { Brit. } 5\end{array}$

Ealys sight-cleft.

23 Dryas,

h 2 Kamschatka.

Brit. 1

24 Tormentilla, *

h 2 Europe.

Brit. 2

Calyx ten-cleft.

25 Calycanthus, scaly, s\&h 2 Carolina.

26 Comarum,

27 Fragaria,

28 Geum, $\uparrow$

29 Potentilla, h

h

h

h \& s 29
1

3 France.

Virginia.
Brit: 1

Brit. 2

Brit. 2

Canada. Norway.Brit. 8

* Tormentilla from the numtier of stamina (being sixteen) appears to be. long to the clals dodecandria, but all the other characters being agreeable to this clals overrule the number of stamine. The root (which is one of the strongest vegetable bitters) hath been frequently used for tanning leather, and is said to be equal to oak bark. See polygonum bistorta.

+ The roots of avens or herb-bennet (geum) smell somewhat like cloves: t.ence this genus was known by the name of caryophillata in the time of Pliny: 


\section{$\left[\begin{array}{lll}90 & ]\end{array}\right.$}

\section{Class XIII. POL Y A N D R I A.}

\section{(Many stamina or males.)}

The flowers of this clafs are furmished with many stamina, (above twenty) inserted into the common receptacle. From this invariable character, is this clafs distinguished from the preceding clafs icosandria; which is very necefsary to observe, as the fruits of this clafs are frequently poisonous.

This clafs contains seven orders.

\section{Order I. MONOGYN I A.}

$$
\text { (One female.) }
$$

no. genera. growth. no of necies. native of

$$
\text { 1 st. One-petal'd. }
$$

1 Alstonia,

2 Marcgravia,

3 Ternstromia,

4 Trilix,

2d. Three-petal'd.

s 1 America.

s 1 W. Indics.

1

s. 1 Carthagena.

3d. Four-petal'd.

Calyx none.

5. Rheedia,

$s$ America.

Calyx two-leaved.

6 Chelidonium,

h

7 Mammea,

t

8. Papaver:

4. Italy.

Brit. 4

h

2 Amcrica. Asia.

9 Alps.

Brit. 6

Calyo

\footnotetext{
* Opium is extrated from the sapacer scmiferunto
} 


\section{POLYANDRI;A。}

no. genera. growtho no. of native of species. Calyx four-leaved, or four-cleft.
9 Actca, + -
h 2 America.
10 Calophillum,
11 Cambogia,
12 Capparis,
14 Grias,
15 Sparmannia,
16 Vallea, India.
1 India.
i5 Italy, \& c .
1 Molucca.
1 Jamaica.
1 Africa.
1

Brit. 1

4th. Five-petal'd.

Capsuies.

17 Cistus,

18 Corchorus,

19 Loosa,

20 Mentzelia,

21 Sarracenia,

22 Sloania,

23 Tilia,

24 Vateria,

25 Muntingia, 26 Myristica, 27 Ochna,

28 Elieocarpus; $d r u$ s $\quad$ \& India.

$$
\text { 5th. Six-petal'd. }
$$

29 Argemone,
Cape, \&c. Brit. 6 h 8 Aleppo.E.\&W.Indies h 1 Peru.

1 America.

h 2 America.

s 2 Brasils.

t. 2 America. Brit. 2

$s 1$ India.

\section{Berries.}

1 W. Indies。

1 W. Indies.

2 Africa. India. h 3 W. Y

$$
\begin{array}{cc}
3 & \text { W. Indies, } \\
\mathrm{N}_{2} & 30 \text { Lagerstræmia }
\end{array}
$$

+ The berries of actea are said to be of very noxious quality.

* The spice called cloves, arc the flowers of the clove tree (caryophyllus aramaticus) got before cxpansion and dricc.

+ The spice called mace, is the sccond coat or covering of the mutmegs (myristica) next to the shell. 
no. genera. grozuth. no. of npecies. native of

$3^{\circ}$ Lagerstramia, s I India.

31 Lecythis, $s \quad 2$ America.

32 Thea, $\left\{\begin{array}{l}\text { bohea, } \\ \text { viridis, }\end{array}\right\}$ s 2 China.

6th. Eight-petal'd.

33 Sanguinaria, h 1 Canada,

7th. Nine-petal'd.

34 Podophillum, h 2 America.

8th. Ten-petal'd.

35 Bixa, * $\quad$ s. W. Indies,

36 Nymphxa, 9 h 4 India. Brit.

toth. Without petals.

Calyx three-leaved.

37 Prockia,

s 1

$3^{8}$ Trewia,

Calyx five-leaved.

39 Delima,

40 Lætia,

41 Seguieria, $s 1$ Ceylon.

$\$ 2$ America.

$\$ 1$ America.

\section{Order II. D I G Y I I}

(Twa females.)

42 Calligonum,

s $\$$ Mount Ararat.

43 Curatella,

* Anotia or arnotta, called by the French roucou, is said to be the red succulent capsule or the covering of the seeds of the bixa orellana: It is collected for the use of dyers and painters; and is also much used in England for coloring chcese and butter. 


\section{$P O L Y \Lambda N D R A$.}

:0. genera. growth. $\begin{aligned} & \text { no. of necies. } \\ & \text { spative of species } \\ & \text { in Brit. }\end{aligned}$

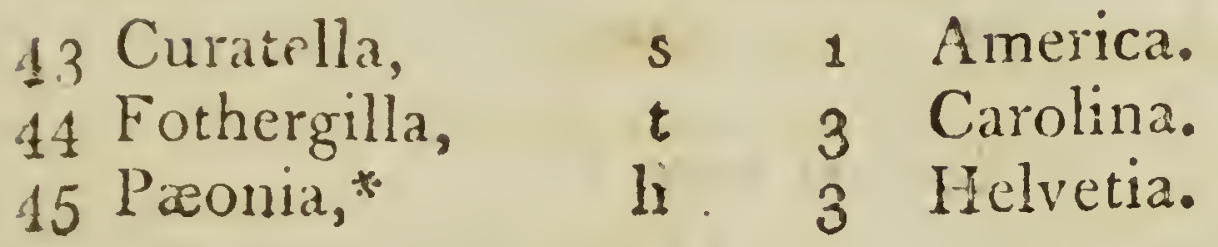

\section{ORDER 11I. T R I G Y I I .}

(Three females.)

16 Aconitum, h. 7 Alps, \&c。

47 Delphinium, h 9 Siberia. Brit.

\section{Order IV. TETRAGYNIA.}

(Four females.)

48 Caryocar,

49 Cimicifuga,

50 Tetracera, s 1 Barbary.

$s \quad 1$ Siberia.

$s \quad 1$ W. Indies.

ORDER V. PEN T A G Y I A.

(Five females.)

51 Aquilegia,

52 Biathys,

53 Nigella,

h 4 Canada.

s 1 New Granada.

54 Reaumuria,

h 3 France, \&c.

h 1 Egypt.

Order VI. HEXAGYNIA. (Six fémales.)

55 Stratiotes, h 3 India. Brit. Order vil. pOL y G Y I A. (Many females.)

56 Drimys,

3 Granada.

57 Michelia,

* In peconia the most natural number of germens are two, but different species have from two to five: The one is called male paony, as having sta. mina; the oilier female, as having no starzina, from its luxuriance. 


\section{$94 \quad$ P O L Y A N D R I A.}

no. genera. growth. no. of native of species 57 Michelia, $\quad s \quad 2$ India.

\section{Calyxes none.}

58 Atragene,

59 Anemone,

60 Caltha,

61 Clematis,

62 Helleborus,

63 Isopyrum,

64 Hydrastis, 65 Thaliderum, 66 Trollius, s 4 Alps. Ceylon. Cape.

h. $25^{\circ}$ Alps. America. Brit. 4 h. 1

s 13 Virginia.

h. .5 Italy.

h 2 Siberia.

h 1 Canada.

h $1,6, \Delta l p s, \& c$.

h 2. Asia.
Brit. 1

Brit. 1

Brit. 2

Brit. 3 Brit. +

\section{Calyxes three-leaved.}
67 Annona,
$\mathrm{t}$
9 Asia. Africa.
68 Liriodendron,
2 Virginia.
69 Magnolia,
4 Virginia.
70 Unona,
71 Uvaria,
1
2 Ceylon. Java.

Calyxes frve-leaved.

72 Adonis,

73 Dillcnia,

h

8 Cape.

$s \quad 1$ India.

74 Ranunculus, . h 41 Crete, \&c.

Brit. 1

Brit. 12

Calyxes six-leaved.
7,5 Illicium,
s 2 China. 


\section{[ 95$]$}

\section{Class XIV. DI D Y N A I A.}

\section{(Two powers.)}

The flowers of this clats are furnished with four stamina, two of which are long and two short; which is the efsential character of this clafs. The two shorter stamina stand nearest to, and approaching the style of the pistillum, received within an irregular corolla.- The flowers of this clals are generally a little inclining from the siem, that the corollia may more easily cover the arithera, and that the pollen may fall on the stigma, and not be injured by rain. - This clafs comprehends the virticil'd, or whorl'd plants, the liped, the masked, and the griming, or ringent flowers of other authors; and in general admits of the following natural charader.

Calyx. A perianthizm of one leaf, erect, tubular, with five clefts, segments unequal; permanent with the fruit.

Corolla. One petal, erect, the base tubular containing honey, and doing the office of a nectarium. The border generally ringent (gaping); the upper lip strait, the lawer lip expanding, with three clefts, the middle cleft broadest.

Stamina. Four filaments, awl-shaped, inserted into the tube of the corolla, and inclined towards the back thereof, the two inner and nearest to the pistillum being shorter; they are all parallel, and scldom exceed the length of the corolla. The antherce are generally covered by the upper lip of the corolla, and approach each other so as to stand in pairs.

pistillum. The germen generally above the receptacie. The style single, thread-shaped, bent in the same manner as the filaments, and usually placed 
placed in the midst of them, but rather long. $\mathrm{er}$, and a little curved towards the summit. The stigma is generally end-nick'd.

Pericarpium. Either none, as in the first order $\mathrm{gym}$. nospermia; or if present, as in the second order angiospermia, it generally consisis of two cells.

Semina. Either four (if no pericarpium) situated in the bottom of the calyx as in a capsule; or. if a pericarpium, there are generally many. fixed to a receptacle placed in the middle of the pericarpium.

This clafs contains iwo orders.

\section{Order I. G Y M N O S P ER M I A.*}

(Seed-naked.)

no. genera. growth. no. of native of $\begin{gathered}\text { species } \\ \text { in Brit. }\end{gathered}$ 1st. Calyxes somewhat five-cleft.

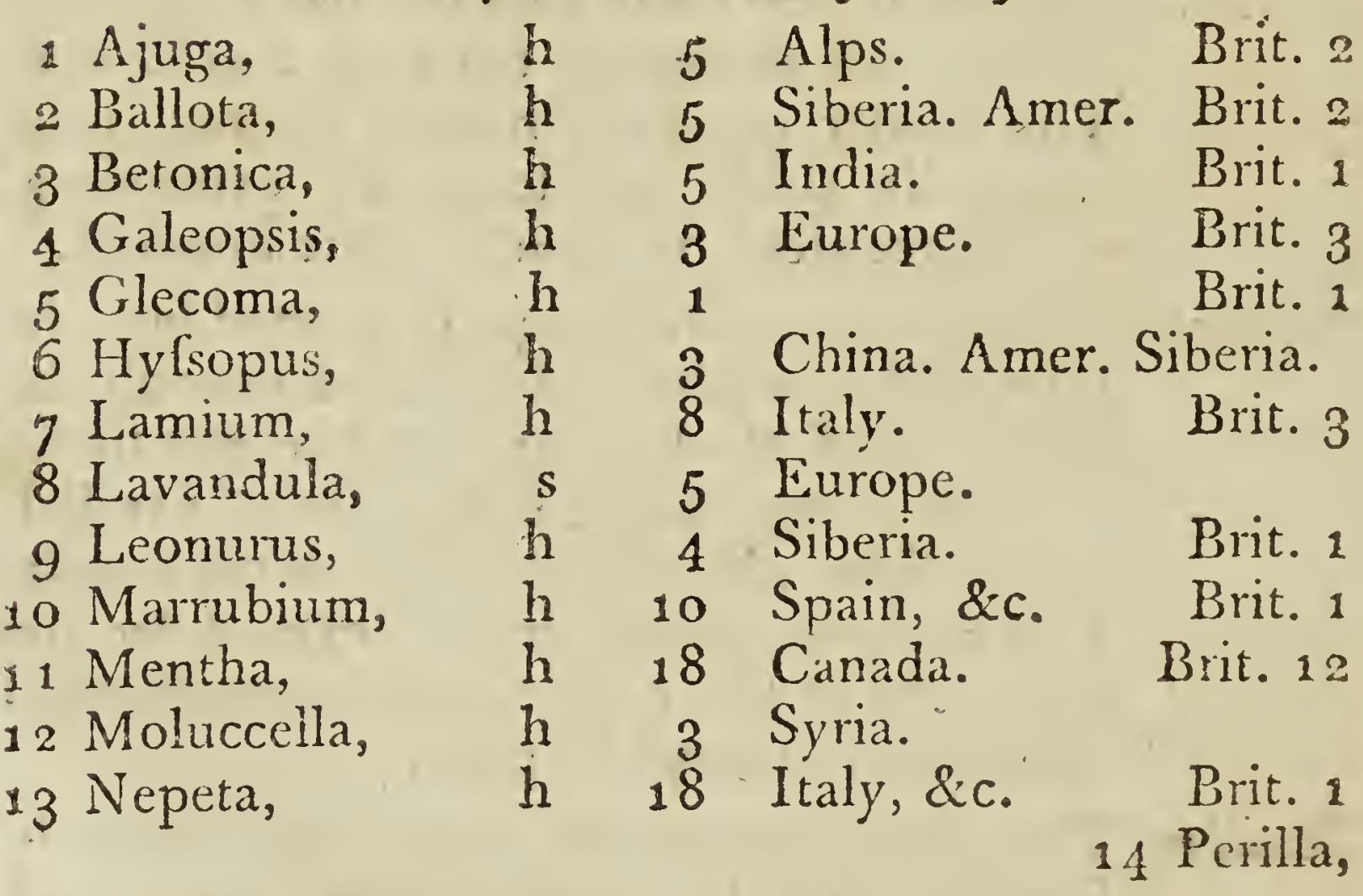

* The plants of this order are scented, and said to be cephalic and resolvent; the virtue in the leaves. None are poisonous. 
no. genera. growuth. no. of necies. native of species 14 Perilla,

15 Phlomis,

16 Saturcja,

17 Sideritis,

18 Stachys,

19 Teucrium, species.

h 1 India.

$s \quad 14$ Ceylon. India.

s \& h 8 France. Greece.

h 11 Canary. Syria.

h 15 . Germany, \&c. Brit. 4

$s \& h \quad 35$ America, \&c. Brit. 4

\section{2d. Calyxes two-lip'd.}

20 Cleonia,

h 1 Portugal.

21 Clinopodium, h 3 America.

22 Dracocephalum, h 15 America. Siberia.

23 Horminum, h 1 Pyrenia.

24 Melifsa,

25 Melittis,

26 Ocymum,

27 Origanum,

28 Phryma,

29 Prasium,

3o Prunella,

31 Scutellaria,

$3^{2}$ Thymbra,

33 Thymus,

34 Trichostema,

h\&s 6 Crete. Brit. 2

h 1 Germany. Brit. 1

h. 16 India, \&c。

h 11 Egypt. Brit.2

h \& S. America.

h 2 Spain. Sicily。

h 4 Europe. Brit: 1

h 15 Italy. \&c. Brit. a

h 2 Macedonia.

h 11 America. Alps, Brit. 2

2 N. America.

Order II. A N G I OS P R M I A.

(Seed-covered.).

1st. Calyxes two-clefto

Capsules.

35 Acanthus,

36 Hebenstretia,

37 Obolaria,

h. 10, Italy, \&c. Cape:

$3^{8}$ Orobanche,

5 Ethiopia.

39 Torenia,

h 1 Virginia.

h 9 Virginia. Brit. 2

h. 1 Asia。

o

Berries. 
no. genera. growth. no. of native of species. Berries.

40 Crescentia, 41 Premna,

42 Halleria,

43 Lippia, 44 Selago,

\section{2d. Calyxes three-cleft.}

$\begin{array}{lll}t & 2 & \text { Jamaica. } \\ \mathrm{s} & 2 & \text { E. Indies. }\end{array}$

$\mathrm{s} 1$ Ethiopia.

3d. Calyxes four-cieft.

Seed single.

$t 4$ America.

s 20 Rithiopia, \&c.

Capsules one-cell'd.

45 Lathræa,

h

4 France.

Brit.

Capsules two-cell'd.

46 Barleria,

47 Bartsia,

48 Euphrasia,

49 Melampyrum,

5o Rhinanthus,

51 Schwalbia,

h 10 India. Jamaica.

h 4 Alps.

h 7 Europe.

h 5 Europe.

h 7 Cape.

1 America.

Capsules three-cell'd.

52 Loecelia,

1 La-Vera-Crux.

Drupes two-cell'd.

53 Gmelina,

54 Lantana,

$\begin{array}{lll}s & 1 & \text { Asia. } \\ s & 9 & \text { W. Indies. }\end{array}$

4th. Calyxes five-cleft.

Capsules one-cell'd.

55 Avicennia, 56 Browallia,
Brit. 2 Brit. 2 Brit. 4 Brit. $\begin{array}{rrr}\text { s } & 2 & \text { Martinico. } \\ \text { h } & 3 & \text { S. America. }\end{array}$

57 Limosella 
no. genera. growth. $\begin{aligned} & \text { no. of } \\ & \text { species. native of }\end{aligned}$ species

57 Limosella,

58 Lindernia,

59 Tozzia,

60 Vandellia, h 2 Europe.

h 1 Virginia.

h 1 Alps.

1 St. Thomas.

Brit. 1

Capsules two-cell'd.

61 Antirhinum, h 46 America. Alps. Brit. 10

62 Bignonia,

63 Buchnera,

64 Capraria,

65 Celsia,

66 Chelone,

67 Columnea,

68 Digitalis,

69 Dodartia,

70 Erinus,

71 Gerardia,

72 Gesneria,

73 Marulea,

74 Mimulus,

75 Pedicularis,

76 Petrea,

77 Ruellia,

78 Schrophularia,

79 Sesamum,

80 Sibthorpia,

81 Stemodia,

$s \& t 19$ America. India.

h 10 America. Asia.

$\mathrm{s} 5 \mathrm{~W}$. Indies.

h 4 Crete.

h 5 N. America.

s 2 Martinico.

h 10 Canary. Brit. 1

h 2 Mount Ararat.

h 7 Alps. Africa. Peru.

h 9 Virginia.

s 3 Jamaica.

17 Cape, \&c.

h. 2 Virginia. Peru.

h 15 Canada, \&c. Brit. 2

$s 1$ S. America.

h 19 W. Indies.

h 16 N. America. Brit. 4 $\mathrm{h} 2$ India.

h 2 Africa. Brit. 1

1 Jamaica.

Cabsules five-cell'd.

8. Martynia, 83 Craniolaria, $\begin{array}{cc}h & 3 \\ \text { h \& s } & 2\end{array}$

S. America.

W. Indies.

Nut two-cell'd.

84 Pedalium,

h 1 Ceylon.

$\mathrm{O}_{2}$

Berry 
no. genera. growth. $\begin{gathered}\text { no. of native of } \\ \text { species. }\end{gathered}$ Berry one-seeded.

85. Bontia, s 1 Antilles. 86 Clerodendron, s 5 India. 87 Cornutia; s. 1 W. Indies. Berry two-seeded. 88 Citharexylon, 89 Ovieda, $t$ 3 TW. Indies. go Volkameria, s 4 Jamaica.

Berry three-cell'd, dry.

91 Linnæa, s 1 Siberia. Berry four-seeded.

92 Duranta, 93 Vitex, 3 W. Indies. s 8 Sicily, \&c. Berry many-seeded. 94 Besleria, 4 America.

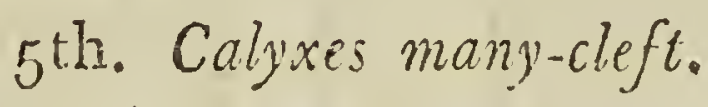
95 Cymbaria, 96 Hyobanche,

1 Dauria.

1 Cape.

6th. Many-petal'd.

97 Melianthus, h 2 Ethiopia.

From the SUPPLEMENT.

98 Amasonia, 99 Castilleja, 100 Hemimeris, 101 Millingtonia, 102 Thunbergia, h

1 Surinam.

h 2 New Granada.

h 3 Cape.

t 1

h. 1 Cape. 


\section{[ $\begin{array}{lll}101 & ]\end{array}$}

\section{Class XV. TE'TRADYNAMIA.*}

\section{(Four powers.)}

The flowers of this clafs are furnished with six stamina, four of which are long and two short. It corresponds with the sitiquosa of $R a y$, and the cruciformes of Tournefort. This clafs (except in one genus, cleome, in which the stamina, in many of the species, are joined to a footstalk supporting the germen, and ought therefore rather to belong to the clafs gynandria) is truly natural; and admits of the following character.

Calyx.

A perianthium, oblong, consisting of four leaves, oblong-egg-shaped, concave, blunt converging, gibbous at the base, standing opposite in equal pairs, deciduous with the corolla. The nectarium is a part of, and formed in the calyx, and often occasions it to be gibbous.

Corolla. Four petals, cruciform, equal; claws flattish, awl-shaped, erect, rather longer than the calyx, limb or border flat, the laminx broadest towards the cnd, blunt, the sides scarcely touching each other. The insertion of the petals is in the receptecte along with the stamine.

Stamina. Filaments six, fixed in the recpptacle, awlshaped, erect; of which the two shorter, that are opposite, are as long as the calyx; the other four rather longer, but not so long as the corolla. The antherce rather oblong, ta-

per,

* The plants of this class are held to be antiscrobutic, the taste acrid and watery: in moist and wet situations their qualities are strongest; but they lose most of their virtues by drying. None are poisonous. These plants applied externally are useful in discases of the skin, as itch, leprosy, \&c. 
per, thicker at the base, ereet. the tops bending outwards.

The nectaria are glands, which appear different in different genera; they are seated close to the stamina, and are gencrally fixed at the base of the shorter filaments, which are generally bent, that they may not prefs upon the glands of the nealaria; and thereby appear shorter than the others.

Pistillum. Germen above, increasing daily in height. Style, either the length of the longer stamina, or none. Stigma obtuse.

Pericarpium. A siliqua (pod) with two valves, often with two cells, opening from the base to the top; the difsepiment (partition) often projecting at the top beyond the valves; which projection had before served as a style. The siliqua is distinguished into siliquosa and siliculosa (long and short pods) which gives rise to the orders.

Semina. In general many, roundish, lodged in the dissepiment (which runs lengthways) and alternately on each side: the receptacle linear, sur rounding difscpiment, and imnersed in the sutures of the pericarpium.

This clafs contains two orders.*

$$
\begin{gathered}
\text { Order I. S I L I Q U O S A.t } \\
\text { (A silique. })
\end{gathered}
$$

Meaning

* In the Gen. Plan. siliculosa is the first order, and siliquesa the second order; lut in the Fragments of a Natural Method, under the order siliquosa, the siligua is the first section, and silicula the second section, which inethod (as it seems more regular) I have here adopted.

+ This order admits of a few exceptions as to the long form of the secd. vefsel, as in bunias, isatis, and especially in cranbe, which hath a round pors one ccll, and a singie seed. 
Meaning such plants whose pericarpium, according to the distinction of Linnæus, is a long siliqua.

no. genera. growth. $\begin{gathered}\text { no. of native of } \\ \text { species. }\end{gathered}$ 1st. Calyx closed with leaflets longitudinally converging.

$\begin{array}{llrll}\text { 1 Arabis, } & \text { h } & \text { 12 } & \text { Alps. Canada. } & \text { Brit. } 3 \\ 2 \text { Brafsica, } & \text { h } & 9 & \text { Alps. China. } & \text { Brit. } 5 \\ \text { 3 Cheiranthus, } & \text { h } & 18 & \text { Alps. } & \text { Brit. 3 } \\ 4 \text { Dentaria, } & \text { h } & 3 & \text { Italy. } & \text { Brit. 1 } \\ 5 \text { Erysimum, } & \text { h } & 6 & \text { Barbary. } & \text { Brit. } \\ 6 \text { Hesperis, } & \text { h } & 6 \text { Africa. } & \text { Brit. 1 } \\ \text { 7 Raphanus, } & \text { h } & 5 & \text { Siberia. } & \text { Brit. I } \\ \text { 8 Ricotia, } & \text { h } & \text { i Egypt. } & \\ 9 \text { Turritis, } & \text { h } & 3 \text { Alps. } & \text { Brit. 2 }\end{array}$

2d. Calyx gaping with leaflets diverging above.

1o Bunias,

11 Cárdamine,

$\begin{array}{rrrr}\text { h } & 8 & \text { Egypt. } & \text { Brit. } 1 \\ \text { h } & 15 & \text { Virginia. } & \text { Brit. } 7\end{array}$

12 Cleome,t h 17 Cape. Indies. Arabia.

13 Crambe,

h 4 Spain.

14 Heliophila,

h 9 Cape, \&c.

15 Isatis,

16 Sinapis, $\}$

if Sisymbrium,

h 4 Portugal.

Brit. 1

h 13 China, \&c.

h 27 India, \&c。

Brit. 1

Brit. 3

Brit. 7

\section{Order II. S I L I C U L O S A. (A silicle.)}

Meaning हैं

* Brafsica (cabbage) greatly abounds in varieties, as brocoli, cauliflower,

+ In many of the species of cleome, there are more than six stamina, and not always unequal as to length; that the only reason for introducing this genus to this clafs, is the nectariferous glands, being three, place at each division of the calyx, except one; yet are often so very small, as scarse to be discoveré̉ by glafses.

The seed of the sinapis arvensis (charlock or ketlock, according to Mr. Miller, is commonly sold under the title of Durham mustar d. 
Meaning such plants whose pericarpium is a little or short siliqua (called silicula,) and is either flat or turgid. no. genera. growth. no. of native of species. 1st. Silicle entire, not end-nick'd at top.

18 Draba,

19 Lunaria,

20 Myagrum,

21 Subularia,

22 Vella, h 8 Alps,

h 2 Hungary.

h 8 Spain, \&c.

h 1

h 2 Spain.
Brit. 3

Brit. 1

Brit. 1

Brit. 1

2d. Silicle end-nick'd at top.

$23^{\prime}$ Alyfsum,

24 Anastatica,

25 Biscutella,

26 Clypeola,

27 Cochlearia, 28 Iberis,

29 Lepidiụm,

30 Peltaria,

31 Thlaspi, s \& h 17 Spain. Alps.

h 2 Jericho. Syria.

h 6 Italy.

h 3 Italy.

h. 8 Denmark.

s \&h 12 Gibralter. \&c. Erit. 2

h 20 America. Alps. Brit. 4 h 2 Cape.

h 11 Alps.

Brit. 6 


\section{$[105]$}

\section{Class XVI. MONADELPHIA.*}

\section{(One brotherhood.)}

The flowers of this clafs have their stamina in one set, that is, they are united at the base into one circular body, in the midst of which statideth the pistillutio.

The genera of this clafs have been variously distinguished by different botanists; some by the petals, others by the fruit and leaves of the plant, but Linnæus found the best and most infallible distinction to be in the calyx, which in the last order is generally double.

This clafs hath the following natural character.

Calyx. A perianthium always press nt, permanent, and in many genera double.

Corolla. Petals five, or five divisions, generally inversly heart-shaped, the sides of which fold one over the other from the right to the left contrary to the motion of the stin.

Siamina. The filaments united at the bottom, separate at the top t the exterior shorter. Thie antliera gentrally kidney-sbaped, and incumbent, that is, fixed by its side leaning to the top of the filameint.

Pistillum. The receptacle of the frudification is prominent in the center of the flower. The germens erect, surrotnding the top of the receptacle in a jointed ring. The styles all united at the bottom into one body with the recepta$\mathrm{P}$ cle,

* The plants of this clars, especially those of the order polyandria, are esteemed emollient and mucilaginous; which properties are common to every part of the plant. None are poisonous.

to In some plants the separation is not to be effeced without a pin or necdle, as in hibiscus, altheri, Bac. 
cle, but separated above into as many threads as there are germens. The stigmas spreading and slender.

Pericarpium. A capsule divided into as many cells, as there are pistilla; of various figures in different genera.

Semina. Kidney-shaped.

This clats contains seven orders, founded on the number of stamina.

\section{Order I. T R I A N D R I A,}

(Thrce stamina or males.)

no. genera. growth. no. of native of $\begin{gathered}\text { species } \\ \text { in Brit. }\end{gathered}$

1 Aphyteia, h 1 Cape.

\section{Order II. PENT A N D R I A.}

(Five stamina or males.)

One female.

2 Lerchea, $s \quad 1$ E. Indies.

3 Symphonia,

4 Waltheria,

$t \quad 1$ Surinam.

$s \quad 3$. E. and W. Indies.

Five females.

$\begin{array}{lrrr}5 \text { Hermannia, } & \text { s } & 17 & \text { Africa, \&c. } \\ 6 \text { Melochia, } & \text { h } & 7 & \text { W. Indies. }\end{array}$

\section{order ili. O C T A N D R I $A$.}

(Eight stamina or males.)

. Aytonia, one fem.... 1 Cape.

$$
\text { Order IV. DEC A N D I A. }
$$

(Ten stamina ox malcs.) 
no. genera. growth. npo of native of $\begin{aligned} & \text { species } \\ & \text { in Brit. }\end{aligned}$

8 Connarus, One female.

9 Geranium,

s 1 India.

h \& s 81. Africa, \&c: Brit. 15

Five females."

10 Hugonia,

1: India.

ORDER V. EN D E C A D R I

Eleven stamina or males.

1s Brownca, one fem.s. 1 W. Indies.

\section{Ordér VI. D O D E C A N D R I $A$.}

Twelve stamina or males.

12 Pentapedes, 1 fem.h 3 India.

\section{Order VII. PO L Y A N R I A.}

Many stamina or males.

One fema!e.

13 Adansonia,

14 Barringtonia,

15 Bombax, *

16 Camellia,

17 Carolinea,

18 Gordonia,

19 Golsypium,t h\&s

20 Gustavia, $t \quad 1$ Senegal.

$t \quad 1$ China Taheite.

$t \quad 4$ E. and W. Indies.

s 1 Japan.

$t \quad 1$ Mexico. Guinea.

s 1 Carolina.

$t \quad 1$ Surinam.

$\mathrm{P}_{2}$

21 Hibiscus,

* The silk-cotton tree (bombax) grow's to a very large size both in the $\mathrm{E}$ " and $W$. Indies, and the wood being rery light, the trunk is chiefly hollowed for canoes.

t The cotton from the Levant is said to be from the go/sypium herbaceum; it is sown in spring, and is ripe in about four months: That from the $\mathbf{E}$. and W. Indies is from a shrub. 
no. genera. growth no. of native of species. $\begin{gathered}\text { species } \\ \text { in Brit. }\end{gathered}$

21 Hibiscus,

22 Mesua,

23 Morisonia,

$24 \mathrm{Sida}$

25 Urena,

26 Stewartia

27 Alcca,

28 Althæa,

29 Lavatera, $3^{\circ}$ Malachra, $3^{1}$ Malope, 32 Malva, s 37. Africa. America.

$s$ 1 India.

$s \quad 1$ America.

h 24 E. and W. Indies.

s. 6 , China. America.

Five females.

Many females,

$\begin{array}{crll}\text { h } & 2 & \text { E. Indies. } & \\ \text { h } & 4 & \text { Italy. Spain. } & \text { Brit. } \\ \text { s \& h } & 6 & \text { America. } & \text { Brit. } \\ \text { s } & 2 & \text { Caribees. } & \\ \text { h } & 1 & \text { Hetrurea. } & \\ \text { h\&s } & 23 & \text { America. Peru. Brit. } 5\end{array}$

Class 


\section{[1109- ]}

\section{Class XVII. D I A D E P H IA.*}

\section{(Twa brotherhoods.)}

All the flowers of this clafs are supposed to have their stamina in two sets or bodies, scverally united at the base: yet though this is the general clarsic character, we are not to imagine it is invariable; for under the firs distinction of the last order, the plants are monadelphious, tha: is, all the stamina are connected; also the two sets of stamina in the last order, are often to be traced with difficulty, for only one of the sets are properly united, the other consisting only of a single filament, which in most plants adheres so closely to the united set, that it cannot be separated without the application of a pin or needle for that purpose, in some you cannot by this means effect a separation. Therefore the plants of this clafs are more easily ascertained by their papiliona. ceous corolla, (resembling a butterfly) with stamina united at the base, $t$ and other parts of the fructification, especially the calyx.

This clats corresponds with the leguminose of Morrison, Hermannus, Boerhaave, Ray', and Roen; with the tetrapetali irregulares of Rivinus and Christopher Knaut; with the tetrapetali difformes of Christian Knaut; and with the papitionacei of Tournefort and Ponteciera.

This clafs is truly natural, and the strucure of the flowers very singular, and their situation mostly obliquely

* The leaves of the plants of this clais are food for catile, and the secds, which are farinaceous and flatulent, are food for men as well as animals. None are poisonous.

+ The papilionaccous corolla alone, is not the general charateristic of this clals; is in decandria. monogynia there are four plants of the same character, viz. sopkora, anggyris, cercis and nymence, but the stcinina are disiring. 
liquely pendant; and adinits of the following general character.t

Caly;. A perianthim of one leaf, bell-shaped, with. ering, base gibbous, the lower part annexed to the fruit-stalk. the upper part blunt, containing honey; the rim five teeth, sharp, unequal; the lower tooth longer than the rest, the upper four stand in pairs, of which the uppernost pair is mostly shorter, and stands further asunder. The bottom of the calyx including the receptacle may be deerned the nectarinim, as it is moistened with a sweet liquor.

Corolla. Papilionaceous, unequal, each petal having a distinct name, (viz.)

The standard, (vexillum) which is the petal covering the rest, incumbent, greater, flat, and horizontal; inserted by its claws in the upper margin of the receptacle, approaching to a circular figure when it leaves the calyx, and nearly entire; an elevated line or ridge marking it lengthways, particularly towards the top, as if the sides were deprelsed. The part of the petal nearest the base is nearly the form of half a cylinder, embracing the parts that lie under it ; the surface of the petal is deprefsed on each side, but the sides nearest to the border are reflexed; and at the unfolding of the half cylinder, are generally two concave appendages, resembling ears. prominent on the under side, comprefsing the wings which lie beneath them.

The

+ The character is not exactly agreable through the wholc ciafs, but as shere are few plants but of the order decandrin, it seems princinally to respeet that order, and particularly those genera that hatc nine stamina joincd. and one distinet. 
The wings (alx) are two equal petals, one on each side of the flower, placed under the vexillum; inner borders incumbent to each other and parallel, broader outward, and dilated into a roundish form; the base of each wing is cloven, the lower division being lengthened in. to a claw, inserted into the side of the recepta. cie, and is about the length of the caly $x$; the upper division is shorter and inflexed.

The keel (carina) is the longest petal inclosing the stamina and pistillun. generally divided, placed under the standard, and between the wings, it is boat-shaped, concave, comprefsed on the sides, placed in the position of a vesscl afloat, lelsened at the base, the lower part extending into a claw nearly as long as the calyx, and inserted into the receptacle; but the upper and side divisions, which are cloven, are interworen with those parts of the wings which most resemble them in shape. The keel either consists of one petal, as in cytisus, or of two adhereing together, as in spartizm, and is distinguished by its shape, as half-moon, spirally iwisted, comprefsed, \&c. The sides of the keel are shaped like those of the wings, and have a similar situation, only lower and more inward. The line that forms the keel runs straight as far as the midile, and then gradually rises in an arch, but the marginal line runs straight to the end, where it obtusely joins the line of the keel.

Stamina. Are most generally ten, either all united, as in the first distinction of the order decandria, or nine united, and one single; the united filaments inclose the pistillum, and the single filament is incumbent upon it. The united filaments are membranaccous below the middle, 
dle, being united into a cylinder, operi on one side through its whole length; along which opening lies the tenth stamen, which is called the other set, and is often so closely attached to the nine, as not casily to be scparated; the membranaceous set of stamina separate upwards into nine distinct awl-shaped filaments, bent like the keel, and of the same length, longer and shorter by pairs: the single filament is awled, or bristle-shaped. simple, and bent as the other nine, but somewhat shorter, and is detached from the rest at the base, to give vent on each side for the honey.

The anthera numbered together are ten, one upon the single filament, and one upon each of the nine divisions of the united filaments, small, equal in size, terminating.

Pistillum. Single, placed upon the receptacle of the flower. The germen oblong. cylindrical, more or lefs comprefsed, as long as the cylinder of the united stamina, by which it is involved. and sometimes, as in erythrina. Esc. it is elevatid by a slender footstalk ifsuing from the center of the calyx.

'The style is single, slender, awl'd. and generally bent, agreeing in length and position with the stamina.

The stignata are generally. covered with a beautiful down, and placed inmediately under the astherat.

Pericarpium. Alegumen, oblong, more or lefs comprefsed, two ralves, with a lotrgitudinal suture both above and below, and either with only one cell, or articulated (jointed) having two or more cells; opening at the upper suture; and is of various shapes in direrent genera. 
Scmina. Generally few, smooth, and are fastened alternatcly along each side of one suture only, and not alternately to both; they are generally kidney-shaped, sometimes roundish, and are marked with an embryo a little pro. minent, at the place where they were fastenied in the pericarpium; and when the seeds begin to grow, the cotyledons retain the form of half the seeds.

The receptacles proper to the seeds are very small, short, and thinner towards the base, inserted along the upper suture only, but placed on each side alternate, so that the seeds adhere to each of the valves.

\section{This clats contains four orders,}

Founded on the number of stamina considered as distinet:

\section{Order I. PENTANDRIA.}

\section{(Five stamina or males.)}

no. genera. growth. no. of native of species.
1 Monnieria,
h 1 America。

\section{ORDER II. HEXANDRIA.}

(Six staminct or males.)

2 Fumaria,

h 14 Siberia, \&c。

Brit. 3

3 Saraca,

Twining plants.-Phascolus, dolichos, clitoria, glycine.

Feathered without an odd one - Orobus, pisum, lathyrus, vicia, ervum, araw chis.

Feathered with an odd one.-Biserrula, astragalus, phaca, hedysarum, glycyrrhiza, indigofera, galega, colutea, amorphia, piscidia.

Thres-leaved.-Trifolium, lotus, medicago, crythrina, genista, cytisus, ononis, trigonella, phaseolus, dolichos, clitoria, monnieria.

Umbel'd plants.-Lotus, coronilla, ornithopus, hippocrepis, scorpiurus. 
220. genera. growth. no. of native of species. 3 Saraca, $\quad s \quad 1$ India.

\section{Order ili. O C T A N D R A.}

(Eight stamina or males.)
4 Dalbergía,
s 2 Surinam.
5 Polygala,
6 Securidaca,
h 37 Brasils, \&c. 'Brit.
s 2 Jamaica. Europe.

\section{Order IV. DEC A N D R A.}

(Ten stamina or males.)

1st. Stamens all connected.

\begin{tabular}{|c|c|c|c|}
\hline 7 Abrus, & $s$ & 1 & India. \\
\hline 8 Amorpha, & S & 1 & Carolina. \\
\hline 9 Anthyllis, & $h \& s$ & 15 & Italy. \&c. Brit. \\
\hline 10 Arachis, & h & 1 & Surinam. Peru. \\
\hline 11 Aspalathus,* & $s$ & 35 & Crete. Ethiopia: India. \\
\hline 12 Borbonia, & $s$ & 6 & Cape. \\
\hline 13. Crotalaria, & h & 23 & China. Carolina. \\
\hline 14 Ebenus. & $s$ & 2 & Crete. Cape. \\
\hline 15 Erythrina,t & $s \& h$ & 5 & Carolina. \\
\hline 16 Genista, & $\mathrm{s}$ & 14 & Spain, \&c. $\quad$ Brit. \\
\hline 7 Lupinus, & h & 7 & Virginia. France. \\
\hline 18 Mullera, & $\mathrm{t}$ & 1 & Surinam. \\
\hline 19 Nilisolia, & $t$ & 2 & America. \\
\hline o Ononis, & h & 29 & $\begin{array}{l}\text { Brit. } \\
21 \text { Piscidi }\end{array}$ \\
\hline
\end{tabular}

* Rose-wood, from whence the olium rhodii, is said to be a species of assalathus.

+ Coral tree (erythrina) called so from the ffowers being collected in lone close spikes of a scarlet color, somewhat resembling coral.-N. 13. Real coral not perfectly known, supposed either to be formed by animals, or to be a mineral. 
no. genera. growth. no. of native of species

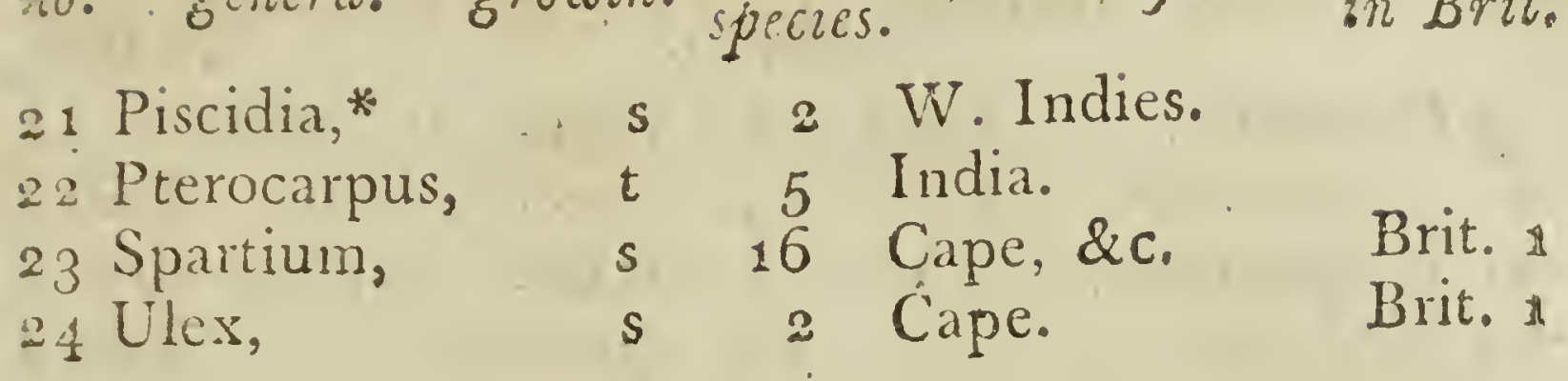
2d. Sigmas downy, (not amongst the former). 25 Colutea, $t$ s\& h 3 Austria. Italy. 26 Dolichos, h\&s 26 China. Cape, \&c. 27 Lathyrus, 28 Orobus, h 21 Tangier. Brit. ? 29 Phaseolus, h 16 America. India, 3o Pisum, 31 Vicia, h 4 Europe. Brit. 1 3d. Legumen somewhat two-cell'd, (not of the former). 32 Astragalus, $\$$ h s 44 Alps, Syria, \&c. Brit. 3 3.3 Biserrula, h 1 Sicily. 34 Phaca, h 1.1 Alps. Siberia.

4th. Legumen mosily. one-seeded, (not of the former). 35 Glycyrrhiza, h4 Apulia. Spain. 36 Psoralia, s 24 Africa. America. 37 Trifolium, h 46 Italy, \&c.

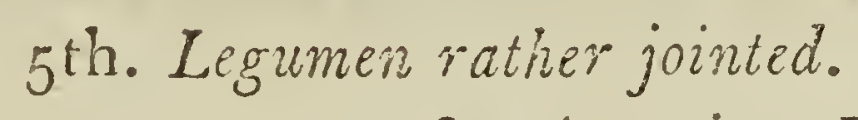
38 Eschynomene, s $\begin{array}{rr}8 & \text { America. India. } \\ \mathrm{Q}_{2} & 39 \text { Coronilla, }\end{array}$

* The bark of the doguood tree (piscidia erythrina) heing pounded and put into a sack, and thrown into any water, and afterwards squeezed, will in a shott time intoxicate the fish, so that they may be taken by the hand, without imparting any bad quality to the fish; a diversion much used in the $W$. Indies.

+ The leaves and seeds of bladder senna (colutea arborescens) being purgative, are often substituted in Italy, \&c. for the senna of the shops: So are also the leaves of scorpion senna, (coronilla emerus).

: 1 Gure tragacanth is from a spccics of astragalus, called astragalus tra. gacantka. 
no. genera. growith no. of native of $\begin{aligned} & \text { species } \\ & \text { in Brit. }\end{aligned}$ 39 Coronilla; s\&h-11 Crete. America. 4 o Hedysarum, s\&h 59 Amer. Persia. Brit. 1 41 Hippocrepis, $h$ : 3 If́ly. Brit. 1 12 Medicago, h 24 America. Brit. 4 13 Ornithopus; h 4 France. Brit. 1 44 Scorpirus, h 4 Europe.

6th. Legumen one-cell'd, many-seieded, (not of the former).

45 Cicer, 46 Clitoria, 47 Cytisus, 48 Ervum, 49. Galega, 50 Geoffrcyá, 51 Glycine, 52 Indigofera, *

53 Liparia, 54 Lotus, 55 Robinia, 56 Trigonella, h 1 Spain.

h 5 Virginia. Brasil. t. 14 Alps, \&c.

h 6 France.

h 12 Spain. America.

t 1 Brasil. Jamaica. h\&s 14 America. $h \& s \quad 23$ E. and W. Indies.

s 6 Cape.

h 19 Arabia.

$s \quad 9$ N. America.

h 12 France. India.

Brit. 2

* Incigo made fiom the leaves of the indigofera tinfloria. 


\section{$[117]$}

\section{Ci.ASS XVII. POLYADELPHIA。}

\section{(Many brotherhoods.)}

The flowers of this clafs have their stamina in three or more sets or bodics, severally united at the hase.

Containing four orders.

\section{ORDER I. PENTANDR I A.}

(Five stamina or males in each set.)

no. genera. growth. $\begin{gathered}\text { no. of native of species } \\ \text { in Brit. }\end{gathered}$

\section{Ambroma,}

2 Theobroma,

h 1

t 3 W. Indies.

\section{Order II. DODECANDRIA.}

(From twelve to twenty males in several sets.)

3 Monsonia, $\$$ \& Cape.

\section{ORDER III. I C OSA N D R I A}

(Tuenty males in scueral sets.) .

4 Citrus,

\& Asia, \&c.

Order IV. POL Y A N I I .

(Many males in several sets.)

falyx two-leaved, beneait.

5. Ascymm, h\&s 3 Virginia.

calyx fine-rleft, aboue.
6 Hopea,
$\$$
- Carolina.

y Melaleucas 
218 POLYADELPHIA。 no. genera. growth. no. of native of species. 7 Melaleuca, s 5 New Zealand.

Calyx five-cleft, beneath.

8 Dario,

9 Glabraria,

20 Hypericum,

21 Symploces, $t \geq$ E. Indies.

E. Indies.

America, \&c. Brit, \&

Martinico.

Calyx six-cleft, beneath.

12 Munchhausia, \& 1 China.

CLASS 


\section{$\left[\begin{array}{lll}119 & ]\end{array}\right]$}

\section{Class XIX. S Y N GENESI A*}

\section{(Confederate Males.)}

This clafs consists of compound aggregate flowers, which (as before explained under the head of distinetion of finwers) are such flowers as are formed by the union of several lefser flowers or florets. placed sitting (or without peduncles) on a common dilated recepiacle, and within a common calyx, called a perianihium; each flo. ret consisting of a single petal, with generally five divisions, and having five stamina distinct at the base, but united at the top by the anthere into a cylinder, through which pafseth the style of the pistillum; longer than the stamina. and crowned by a stigma with two divisions that are rolled backwards; and having a sin. gle seed placed upon the receptacle under each floret. - This is the general character of a compound flower. to which there are a few exceptions in the order mono. samic ; but the efsential character consists in the antherce being united so as to form a cylinder, and having a single seed placed upon the receptacle under each

floret:

* The name of this clafs means congeneration, alluding to the circumstance of all the stamina being united by their anthera, and therefore is translated confederate males.

Some flowers have sich close heads, as at first sight appear to be of the clafs syngenesia, but if they want the efsential character of a compound llower, they belong to some other clafs. - The florets in a compound flower have generally a small calyx, which is always a perianthium, and remains, so as to become the crown of the seed.

This clais differs from the adelphia clarses, in the stamina not heing joined at the bottom by the filaments, but at the top by the antheræ.

This clafs is natural, except the last order monogamia, which upon systematic principles was found necelsary to be admitted, as having the anthera united.

The plants have varinus specific virtues, though most of them are bitter and stomachic. None of them are poisnnous, except perhaps lactuca virosa (strong scented lettuce) especially in shady situations; and doronicum (leo. pard's bane) and carthamus (base safron or safflower). 
floret: yet this is not without some exceptions in the order monogamia.

Linnxus also gives a further charafter of a flower in its compound sute, (taken from the calyx and receptacle, the only parts that are in common, and by which antient botanists founded their distinction, and also of a floret: The first he calls flos universalis, and the florets of which it is composed, he calls fores propriz.

Charatter in the rompound state.

Calyx. A common perianthim containing the receptacle and forets; which contraets when the florets are fallen, but expands and turns back when the seeds are ripe. It is either simple, as when composed of only a single row of secds cr lcaves; imbricated, (tiled) as when the scales are numerous, and the outer lie upon the inner, like tiles upon a house; or augmenied, (increased or leafy) as when a single row of longer leaves or segments of the calyx surrounds the florets, and ancther row of very snall leaves or scales surrounds the base of those longer leares or segments.

Recopacie. Is the common receptacle of the fruedifation, receiving many florcts sitting on its disc: which is either concave, convex, flat, pyramidal, or globular; and the surface of the disc, is either naked, without other inequality than that of being lightly dotted, as in leontodon, $\mathcal{E}^{2}$ c.; hairy, covered with upright hairs, as in cardists, Eंc.; or chafy, covered with linear, awl-shaped, comprefsed, upright palex or chaffy substances, scparating the florets, as in aninemizis, achillea, Eco

\section{Charabier of a fioret.*}

Caiyx. When present, a small perianthim with generally

* The claracter here given is of an hermaplirodite floret. 


\section{SY $\mathrm{N} G \mathrm{E} N \mathrm{E}$ I A.}

nerally five clefts, sitting upon the top of the germen, and afterwards becoming the crown of the seed.

Corolia. One petal, tube very narrow, long, seated on the germen, with generally three or five clefts or teeth: And is either tubular, with the border funnel'd or bell-shaped, the segments reflexed and expanding; or ligulate, (from ligula, a strap of fillet) having a short tube with border linear, flat towards the outward side, and the top loped. In some genera, the corolla in some of the species is wanting, as in artemisia and gnaphalium.

Stamina. Filaments five, capillary, very short, inserted in the neck of the corollula. The antherce five, ereet, linear, joined at the sides so as to form a hollow cylinder with five teeth, and as long as the border of the floret.

Pistillum. Germen oblong, placed under the floret; upon the common receptacle. The style threadshaped, erect, as long as the stamina, pafsing through the cylinder formed by the anthera. The stigma two parts, the parts rolled back, and expanding.

Pericarpium. Properly none, though in some genera there is a coreaceous or leathery crust over the seed, as in osteospermum and strumpra.

Semina. Single, oblong, often with four edges, generally narrower at the base, and are crowned either with a feather, (pappus) or with the perianthium, or hath no crown; if with a feather, it is either sitting, or placed on footstalks, (stipes) consisting of many radii placed in a circle, which are either simple, radiate, or branching; if with a perianthium, it is small, permanerit, with generally five teeth. 
This clafs contains six orders.

\section{Order I. POLYGAMIA EQUALIS. (Equal polygamy.)}

It is called equal because all the florets are hermaphrodite, and none of them radiate (except atractylis).

no. genera. growth. no of native of species. 1st. Semiflosculous: flowers of Tournefort with all the corals ligulated. Receptacle chafjy.

1 Catananche,

2 Cichoreum,

3 Geropogon,

4-Hypocharis,

5 Scolymus,

6 Seriola, h

h

h

h

h

h
Crete. Greece.

3 Eurupe.

Brit. I Italy. Europe. Spain. Italy.

Crete. Italy. Etna.

Receptacle

ORS. The disposition of the seres varying, occasions the following distinctions:-It is called a tubular hermaphrodute floret, if stamina and pistillum are both present; a tubular masculine floret, if furnished with siamina but no pistillum or stigmn; a tubular feminine floret, if a pistillum without stamina; and a tuhular neuter floret, if neither stamina nor pistillum. If the corolln of the floret is ligulate, then it is called a ligulnte floret, and either hermaphrodite, masculine, feminine, or neuter, according to the foregoing distinctions.-Besides the ahove description, compound flowers, from the difference of their structure, admit of further divisions, which give rise to the orders.

When all the florets are tubular, that is, consist of hollow, tubular, funnel-shaped petals, they are'called flosuli, and the whole flower is called flos finsculosus. This term seems opposed to radiate flowers, where the flowers of the radius differ in form from those of the disc. See the note to ceniariea.

* Semifnosculous flowers of Tournefort, mcan such florets as are flat above, and tubular or hollow helow, as dandelion. goat s-beard, hawhweed, $E_{C} c$. and correspond with the ligulati of Linnaus; the lingulati of Pnntedera; the pianipeteli of Bocrhate and Ray; the cicloracei and acaracca of Casalpinus; and the laktcscntes of Morison. 


\section{S Y NGENESIA.}

no. Eenera. growth. $\begin{aligned} & \text { no. of native of species } \\ & \text { species. }\end{aligned}$

\section{Recejtacle villous or hairy.}

7 Andryola,

h 3 France.

Receptacle naked.

8 Chondrilla,

h 3 Germany.

9 Crepis,

to Hieracium,

h 16 Alps. Siberia.

Brit. 3

h 34 Alps. Cape. Brit. 9

11 Hyoseris,

12 Lactuca,

h 9 Virginia.

Brit. 1

13 Liapsana,

h 8 India. Canada. Bri:-3

h 5 Portugal. Brit. 1

14 Leontodon, h 9 Europe. Brit. 4

15 Picris,

16 Prenanthes,

h 3 Italy. France. Brit. 2

17 Scorzonera,

h 10 Japan, \&c. Brit. 1

13 Sonchus,

in 12 Spain, \&c.

19 Tragopogon,

I \& s 15 Alps. Siberia. Brit. 4 h 11 Virginia. Brit.

\section{2d. Headed flowers.}

That is, connected on the summit of the footstalk into a knob or head.

20 Aretium,

31 Atractylis,

h

2 Barnadesia,

h 6 Italy. Mexico.

23 Carduus,

$\mathrm{s}$

1 America.

24 Carlina,

h 33 Syria. Virginia. Brit.11

25 Carthamus,

h 8 Pyrenean.

Brit. 1

26 Cnicus.

27 Cynara: h \& s 10

Crete. Egypt.

28 Oropordon,

h

h

9 Europe. Spain.

29 Sexratula,

4 italy,

h 5 Arabia. Brit. 1

is

$\mathrm{R}_{2} 4$ Alps, \&C.

Brit. 1

Brit. 3 3d. Discu

* The csculent part of the cynara scolymus (common artichoke) is the ca. l; $x$ and recepiacle: as in onopordon acanthium the recetacle and young stems are cat as orithohes. 
no. genera. growth. no. of native of species. 3d. Disc-like flowers.

That is, placed on a surface like a disc; as the disc of the sun, moon, \&c.

$$
\text { Receptacle naked. }
$$

30 Ageratum,

31 Cacalia,

$h$

2 America.

32 Chrysocoma,

h \&.s 26 Alps. Africa.

33 Ethulia,

h\&s is France. Africa.

34 Eupatorium,

35 Spilanthus;

$\mathrm{h}$

h

h
5 India.

27 Ceylon. China. Brit. 1

\section{Receptacle chaffy.}

$3^{6}$ Athanasia,

37 Bidens,

38 Calea,

39 Santolina, 4o Stæhelina,

h 20 Cape, \&c.

Brit. 1

h 12 America.

4 Jamaica.

s 4 Spain. Alps.

s 8 Africa.

Receptacle hairy or brisiley.
41 Pteronia,
s 27 Ethiopia.
12 Tarconanthus, s 3 Cape.

ORDER II. POLYGAMIA SUPERFLUA.

(Superfluous polygamy.)

Having the florets of the disc hermaphrodite, and those of the radius or circumference female, which arc conșidered as superfluous.

\section{1st. Disc-like flowers. \\ Receptacle naked.}

43 Artemisia, * h\&s 25 Ethiop. China. Brit. 5 44 Baccharis,

* The moxa, so famous in the east for curing the gout, by cauterizing the part affeeted, is the lanugo or down of the leaves of a species of Indian muswort (artemisia). 


\section{SY Y GENES IA.}

130. genera. growth. no. of native of species

44 Baccharis,

45 Carpesium, 46 Conyza,

47 Cotula;

48 Gnaphalium,

49 Tanacetuin, s 8 America. Africa.

h 2 Italy. China.

h \& s 25 China, \&c.

h 13 Spain, \&c.

Brit. i

s\&h 58 Alps. India.

Brit. 6 h\&s 7 Siberia. Africa. Brit. 1

\section{Receptacle chaffy.}

50.Anacyclus, h 4 Crete.

51 Xeranthemum, s\&h 17 Austria, \&c.

2d. Semiflosculous flowers, rather two-lip'd.

Receptacle naked.

52 Perdicium,

$$
\text { h } 4 \text { Alps. }
$$

3d. Radiate flowers.*

Receptacle naked.

53 Arnica,

54 Aster,

55 Bellis,

56 Bellium,

57 Cineraria,

58 Chrysanthemum, h

59 Doronicum,

6o Erigeron,

61 Helenium,

62 Inula, +

63 Matricaria,

64 Mutisia,

65 Pectis, h.

$5 \& h \cdot 36$

h 2

s \& h 24 Siberia. Eape. Brit. 2 h 23 Alps, \&c.

h 3 Alps.

h 20 Alps. America. Brit. h 1. America.

h. 24 Arabia. Germ. Brit. 4 h 6 Europe. New Granada. h. 3 America.
Brit. 4

66 Senecio,

* Sec radiate flowers described in a note under the head of distincion of flowers.

\& In inula the two bristles fixed to the lowe part of each lip, is the ersential character. 
no. genera. growth. no. of native of species. 66 Senecio, h\&s 57 Fgypt. Siberia. Brit. 8 67 Soliuago, h 14 Canada. Brit.2 68 Tagetes, : : : 3 Mexico.

69 Tufsilago, h 10 Alps. Japan. Prit. 3 go Unxia, h 1 Surinam.

Receptacle chaffy.

71 Achillea,

72 Amellus, h so Egypt, \&c.

Brit. 2

73 Anthemis, hes 2 Cape.

74 Buphthalmum, h is America.

75 Eclipta, ..... h 3 Virginia.

75 Leycera,

77 Sigesbeckia,

78 Tridax,

79 Verbesina,

80 Zinnia,

3 Erthiopia. Callifornia.

2 China.

h 1 Vera-crux.

h

h

China. Vi.ginia.

Peru.

\section{Order III. POLYGAMIA FRUSTRANEA. \\ (Frustraneous polygamy.)}

Having the floret of the disc hermaphrodite, and those of the radius neuter; * hence called fmistraneons. All radiate.

Receptacle nakedish.

81 Gorteria,

82 Centaurea, s \& h. 12 Africa.

Receptacle brisily.

h 66 Alps. Asia.
Brit. 5

83 Zagat,

* The florets in the radius are described as female in the Gen. Plantcrum; but some part being defective, and consequently barren, they are called neuter.

t In centaurea the scaics of the calyx, and the feathers of the seeds, differ in different species; and the florets of the radius differing from those of the disc as to sex and size, apparently brings it under the description of a radiate fiower; but as the Morets are all tubular, Linneus hath not called it radiate, but tubulous of different forms. - The flowers of centaurea cranus (hlue-bottle) make a good blue, which with the addition of a little allum becomes permanent. 


\section{$S Y N G E N E S I A$.}

io. cerera. growith. 3 species. of native of species

$8_{3}$ Zagaa,

2 Cape.

Recepiacle chaffy.

3 Corenpsis, $\quad h$ a Virginia, \&rc.

85 Helianthus, h 13 India. America.

86 Osinites, $s$ \& 4 Cape.

87 Rudbeckia, h 6 Canada. Carolina.

ORDER IV. POLYGAMIA NECESSARIA. (Necesary poingany.)

Iaving the florets of the disc male, and those of the radius female; hence called necefsary.

Receptacle naked.

88 Baltimora,

h 1 Maryland.

89 Calendula, h\&s 9 France, \&c.

go rilago,

h 7 France.

Brit. 3

91 Hippia,

92. Micropus,

h\&s 3 America.

93 Milleria,

h 2 Spain.

94 Osteospernum, h 15 Africa. America.

95 Othonna, h\&s 26 Africa. France.

Receptacle hairy.

g6 Arctotis, his 17 Ethiopia, \&c.

97 Eriocephalus, $s \quad 2$ Africa.

Receptacle chaffy.

98 Chrysogonum, h 1 Virginia.

99 Melampodium, h 2 America. Vera-crux.

soo Polymnia, h 7 Canada. Abylsinia.

101 Sylphium, h 8 America. 
Order V. POLYGamia segregata.

\section{(Separate polygamy.)}

Such flowers as have many partial or lefser calyxes contaning one or more florets, and placed within a common calyx, by which the florets are separated.

no. genera. growth no. of native of in species One floret.

$\begin{array}{lll}102 \text { Echinops, } & \text { h } & 4 \text { Italy. } \\ 103 \text { Stœbe, } & \text { h. } 9 \text { Africa. }\end{array}$

104 Jungia,

Three florets.

1 America.

Four florets.

105 Elephantopus, h 2 E. and W. Indies.

Five fiorets.

106 Gundelia, $\because h, 2$ America.

\section{Eight florets.}

107 Spharanthus, $\mathrm{h} \quad 3$ India. Africa. China.

Many florets.

108 CEdera, $\quad$ s 2 Cape.

\section{Order Vi. MONOG a Mi.}

(Monogamy.)

Containing simple flowers with the anthere united. 1.09 Corymbium, h 6 Ethiopia.

$\begin{array}{lrrll}110 \text { Jasione, } & \text { h } & 2 & \text { Europe. } & \text { Brit. 1 } \\ 111 \text { Impatiens, } & \text { h } & 7 & \text { China. } & \text { Brit. 1 } \\ 112 \text { Lobelia, } & \text { h } & 42 & \text { Ceylon, \&c. } & \text { Brit. 2 } \\ 113 \text { Seriphium; } & \text { s } & 4 & \text { Ethiopia. } & \\ 114 \text { Strumpfia; } & \text { s } & 1 & \text { America. } & \\ 115 \text { Viola,* } & \text { h \& s } 29 & \text { America, \&c. } & \text { Brit. 6 }\end{array}$

* In Europe the flower of the common violet always hangs down, in the Indies it is generally upright.

Cinass 


\section{$\left[\begin{array}{ll}129 & ]\end{array}\right.$}

\section{Class XX. G Y N A N D R I A.*}

\section{(Feminine males.)}

The flowers of this clafs are distinguished by having the stamina placed upon the style. or rather, upon a col. umnar receptacle lengthened out into the form of a style, supporting both the stamina and pistillum.

In examining and comparing the characters of this clafs, it is more necefsary to attend to the pistillum before the stamina, in order to attain a discinct idea of the latter.

All the flowers of this clafs have a very singular ap. pearance, owing to the uncommon disposition of the sexes.

The first order (DIANDRIA) of this clafs is natural, and its genera (formerly distinguished by the root) Linnæus distinguisheth by the nectarium alone.

The flowers also of this order are very singular, having the following description.

Calyx. A spatha protruding a spadix, and the flowers have no perianthium.

Corolla. Five petals, of which the two inner generally approach so as to form an helmet, the outer are larger, and nearly equal; the lower lip of the helmet constitutes a nectarium, and hath the appearance of a sixth petal; and the upper lip is incorporated with the style of the pistillum.

Stamina. Always two, the filaments very short, sup$\mathrm{S}$

porting

* The rame of this clafs means woman-man, in allusion to the singuiar circumstance of the stamina growing upon the pistillum; so that the male and female are united, and do not stand separate as in other flowers; and is therefore translated feminine males. 
porting two anthera, narrower downwards, naked, and divisible: The antherce are generally inclosed by litile cells, cpen underneath, and covered by a fold of the upper lip of the netarium.

Pistimm. Germen alway below the corolla, oblong. and twisted like a screw. Style single, very short, forming one substance with the inner margin of the upper lip of the nectarium, so as buth style and stigma are scarce to be perceived.

Pericarpium. A capsule, one cell, three valves, opening at the angles under the kecl-shaped sutures, and joined both at top and bottom.

Semina. Very small, like saw dust, very numerons, fixed (without footstalks) to a linear receptacle, at each valve.

\section{Observation.}

It is observed that though the stamina in this firft order, are only considered as two; yet each of them appears to be composed of a great number of elastic fibres united together; each fibre supporing its own proper anthera: these fibres branch out into lefser, each supporting at its point an extreme minute anthera.

\section{This clafs contains nine orders.

$$
\text { ORDER I. DI A N DRIA.* }
$$

$$
\text { (Two males.) }
$$

no. genera. growth. no. of native of species

1 Arethusa, h 7 Virginia. Cape.

2 Cypripedium, h 2 Lapland. Brit. 1

3 Disa,

* The plants of this order are pofsefsed of restorative qualities, which chiefly beiong to the roots: they are acrid when fresh, but lose that qualing when dry, or by warm water. 


\section{GYNANDRIA.}

no. genera. growth. no of native of species 3 Disa, $\quad$ h 4 Cape.

4 Epidendrum, : 31 E. and W. Indies.

5 Forstera, $\quad \mathrm{h} 1$ New Zealand.

6 Gunnera, $s \quad 1$ Cape.

7 Limodorum, h 2 Jainaica.

8 Ophrys. - h 27 Alps. Brit. 13

9 Orchis, $*$ h 45 Italy. Asia. Brit. 11

10 Satyrium, h 15 Cape. Brit. 4

1 Serapias, h 3 Cape. Brit.

\section{Grder II. T I A N D R I $A$,}

(Three males.)

One-female.

12 Ferraria,

13 Salacia,

h 2 Cape.

14 Sisyrinchium, h 2 Bermuda.

15 Stilago,

1 India.

ORDER III. TETR A N D R I A .

(Four males.)

One-female.

16 Nepenthes, h \& Ceylon.

ORDER

t The senclloes, which is an ingredient in chocolate, is the pod of the spidendrum vanilla. Most of the species are parasitical.

* Salep is the root of a species of orchis. The flowers of the different species of orchis and ophrys are very various; oft resembling different kinds of animals and insects, which have given names to many of the species.

$\neq$ Ferrario only vegetates every second or third year, though the root remains from in the ground. 
Order IV. PEN T A N D I A.

(Five males.)

no. genera. grozuth. no. of native of species.

One-female.

17 Ayenia,

28 Gluta,

$\begin{array}{ccl}\text { h } & 3 & \text { Jamaica. } \\ \mathrm{s} & 1 & \text { Java. }\end{array}$

Three-female.

19 Pafsifora, s 28 Brasils, \&c.

OrDER V. HEX A N D R I A.

(Six males.)

Six-female.

20 Aristolochia, h 21 France. India. Brit.

One-female.

2: Pistia,

h 1 Asia. Africa.

Order vi. oc T a n d r i a.

(Eight males.)

22. Scopclia,

$t \quad x$ Java.

Order Vil. DECAN DR I A.

(Ten males.)

One-fenale.

23 Helicteres, s 1 Jamaica. Carthagena.

24 Kleinhovia, $t+$ E. Indies.

\section{Order Vilit. D O D E C A N D R I A.}

(Twelve males.)

One-female.

25 Cytinus,

1 Spain。 


\section{G Y N A N D R I A. \\ ORDER IX. POLYANDRIA.}

\section{(Many males.)}

20. genera. growtin. no. of native of species. Dne-fenale.

26 Grewia,

27 Xylopia,

28 Ambrosinia, 29 Arum, 30 Calla, 31 Dracontium, $3^{2}$ Pothos,

$33^{2}$ ostera, ${ }^{*}$ s 6 Asia. Cape.

$\$ 2$ America.

Spathe.

51 Palermo in Turkey.

h 25 Virginia, \&c. Brit. 2

h 2 Ethiopia.

s. 5 W. Indies.

$\$ 7$ America.

Leaf.

h 2 Holland.

Brit. $\mathbb{1}$

* The Zostera marina is very plentiful in the Zuyder Zee in Holland, and is of great use in constructing their banks: when the lighters are laden with it, the fumes which arise, will affeet the watermen with yiolent pain in the eyes, and even with temporary blindnels. 


\section{[ 134$]$}

\section{Class XXI. M O N $\mathrm{OE}$ C A.}

\section{(One house.)}

This clafs consists of such genera as have male and female flowers distinet and separate from each other, on the same plant, which Linnzus calls androgynous\% plants.

But it is to be obscrved, that forets contained within a common calyx, though agreeing in this clisposition of the sexes, do not belong to this class; which caution is necelsary to exclude several specics of genera of the umbellate and compound flowers, which are sometimes androgynous, but have united antherce. There are also a few other plants dispersed in the several clafses, which properly belong to this clafs, but as they are only species agreeing with the generic character under which they are placed, they are suffered to remain; as callitriche verna, plantago uniflora, rumex spinosuls, glycine monoica, arum triphyllum, mercurialis ambigua.

This clafs contains eleven ordcrs,

Founded on the number, union, and siuation of the stamina in the male flowers.

$$
\begin{aligned}
\text { ORDER I. } & \text { MONANDRIA. } \\
& \text { (One male.) }
\end{aligned}
$$

no. genera. growth. $\begin{gathered}\text { no. of native of } \\ \text { species. }\end{gathered}$

1 Ceratocarpus, h 1 Tartary.

2 Chara,

3 Elaterium,

h 4 Europe. Brit. 4 h 2 Carthagena.

4 Phyllachne.

* See androgynous under distinetion of flowers. 


\section{MON E CIA.}

no. genera. growth. no. of native of in Brit. 4 Phyllachne, $h{ }_{1}$ Tcrsa del Fuego. 5 Zannichellia, in 1 Brit. Anentum.

$\begin{array}{llll}6 \text { A goprigon, } & t & 1 & \text { Surinam. } \\ 7 \text { Artocarpus, } & t & 2 & \text { Batavia. Java. } \\ 8 \text { Casuarina, } & & 1 & \text { India. } \\ 9 \text { Cynomorium, } & \text { h } & 1 & \text { Janaica. }\end{array}$

ORDER II. DI A NDR I A.

(Two males.)

$\begin{array}{llll}\text { 10 Anguria, } & h & 3 \text { America. } \\ \text { 11 Linna, } & h & 5 & \text { Europe. }\end{array}$ ORDER III. TRI A N D R I . (Three males.)

12 Axyris, s\&h 4 Tartary. Siberia.

13 Hernandia, $s$ \& India.

1 Omphalia, s 2 Jamaica.

15 Phyllanthus, s\&h 8 Jamaica. India.

16 Sparganium, h 2 Europe. Brit. 2 17 Tragia, $s \& h \quad 6$ India. Virginia. 18 Typha,

h 2 Europe. Brit. 2 Gluma,

19 Coix,

20 Olyra,

21 Tripsacum,

22 Zea,

23 Carex, *

h 1 India.

b 1 Jamaica.

h 2 America.

h 1 America.

Amenium.

h 49 India. Lapland. Brit. $3^{8}$

ORDER

* The Laplanders make great use of the corex vesicaria (bladder carex) in stuff in their shoes in winter to keep out cold, and in summer to keep their feet from sweating; they also stuff their gloves with it to preserve the hends. 


\section{ORDER IV. TETRANDRIA.}

(Four males.)

no. genera. growth. no. of native of .... species

24 Betula,

25 Buxus,

26 Centella,

27 Cicca,

28 Littorella,

29 Morus,

30 Serpicula,

31 Urtica, * $t 6$ Virginia.

s, 2

h. 2 Cape.

$\tau$ I India.

hi $i$

t 7 China. America.

h 2 India.

h. 25 Canada. Cape. Brit. 3

Brit. 3 Brit. 1

Brit. \&

\section{ORDER V. PENTANDRIA.}

\section{(Five males.)}

32 Amaranthus, h 24 Ganges, \&c. Brit.

33 Ambrosia,

34 Clibadium,

h 4 Virginia.

35 Iva,

36 Leea,

h\&s 2 America.

37 Nephelium,

$s \quad 2$ Cape. India.

38 Parthenium,

$s \quad 1$ India.

39 Xanthium,

h 2 Jamaica.

h \& s 4 E. Indies.

\section{ORDER VI. HEX A N D R I $A$.}

(Six males.)

Calyx grume, none.
40 Zizania,
$\mathrm{h}$
2 Jamaica.

Calyx glume, one lowered.
41 Pharus,
h.
1 Jamaica.

ORDER

* The three British species of urtica, are the urtica pilulifera, (the Roman stinging nctle, ) urtica urens, (the anmual stinging nettic,) and urtics dioica, (the perennial stinging nettle). 


\section{$\mathrm{MON}$ OE $\mathrm{I} A$}

Order VII. hEPT A N R I A.

(Seven males.)

no. genera. growth. no. of native of in Bries. 42 Guettarda, $t \quad 1$ Jamaica.

Order vili. pOLYANDRIA.

(Many males,-more than seven.)

43 Begonia, h 4 india. Cape.

44 Ceratophillum, $t \&$ h 2 Europe. Brit. 2

45 Fagus,

$t \quad 3$ Italy.

Brit. 2

46 Liquidamber, $t$ 2 Virginia.

47 Myriophyllum, h 2 Europe. Brit. 2

48 Paterium,

49 Quercus,

50 Sagittaria,

3 Europe.

Brit. 1

51 Theligonum,

t. 13 Molucca, \&ç. Brit. I

h -5 America. China. Brit. 1

h 1 Italy.

Male, amentum imbricated.
52 Carpinus,
s. 2 America.
Brit. 1
53 Corylus;
2 Europe.
Brit. 1
54 Juglans,
5 America.

Amentum globular.

55 Platanus, $\quad$ t 2 E. and W. Indies.

Order IX. MONADEL P H I .

(One brotherhood.) Stamina united at the base.

56 Acalypha, $\quad h \quad .5$ Virginia.

57 Croton, s\& 25 Japan. America.

58 Cupania, $s$. America.

T 59 Dalechampia,

* Kermes (a species of inseet called coccus infectorius; is found on an ever. green oak, (quercus coccifera,) and was much used in dyeing before cochineal was knows. Both this and cochineal wese for a long time considesed as a grisin. 
no. genera. growth. no. of necies. native of species

59 Dalechampia,

60 Hippomane, *

61 Hura,

62 Jatropha, $t$

63 Plukenesia,

64 Ricinus st

65 Sterculia, 66 Stillingia, $s$ : 2 America.

$\mathrm{t} 3 \mathrm{~W}$. Indies.

$s$

s \& h

$\mathrm{s}$

h

$s$

$S$
1 Mexico.

9 America. Africa.

1 India.

3 E. and W. Indies.

3 India.

1 Carolina.

\section{Amentum.}

$\begin{array}{lrrll}67 \text { Cuprefsus, } & t & 5 & \text { Crete. Japan. } & \\ 68 \text { Gnetum, } & s & 1 & \text { India. } & \\ 69 \text { Pinus, } & t & 12 & \text { Canada. } & \text { Brit. } 3 \\ 70 \text { Thuja, } & t & 4 & \text { Canada. } & \end{array}$

ORDER

* The manchineel tree (hippomane mancinella) is one of the most poisonous trees that grows; not only the fruit, but the wood and every part is noxious: The Indians use the milk or juice to poison their arrows.

+ The root of the manihot or manioc, (jatropha manihot) properly prepar$c d$, is much used in the W. Indies for bread, then called cafsada, and esteemed very wholesome; although in its recent state it is a strong poison.

\# Castor oil is exprefsed from the seed of the racinus communis, formerly called palma christi, or agnus castus.

Venice turpentine is from the larch tree; (pinus larix ;) Burgundy pitch is from the fir, (pinus abies).

Former botanists, before Linnxus, distinguished the fir from the pinc, by the insertion of the leaves; those of the fir are produced singly from the branches; those of the pine grow by twos, threes, or fives, out of a little sheath that surround's their base, and when fitted together, they form a cylinder.Linnæus hath included both sorts under one genus, (pinus) but hath made the same distinction in the species as above; except having added the cedar and larch to the same genus, the leaves of which proceed from a sheath, but growing in hunches, he calls fascicled.-Great varieties proceed from the seeds of the several species of the pine and fir. 


\section{$M O N$ OE C I A.}

\section{Order X. S Y N GE NES I A.}

(Confederate males.) Stamina united at the top.

no. genera. growth. $\begin{aligned} & \text { no. of necies. native of in Brit. } \\ & \text { in }\end{aligned}$

Calyx five-cleft, or five-toothed.

7\% Bryonia,

72 Cucumis,*

73 Cucurbita,

74 Trichosanthes, $\mathrm{h}$

75 Momordica,

76 Sicyos, h 9 Africa. Crete. Brit. 1 h 12 Africa. Jamaica.

h 6 America.

h 4 China.

h 8 India. America.

h 3 Canada.

\section{Order XI. G Y N A N D R I A.}

(Feminine males.)

The stamina growing on a sort of style, cr imperfect pistillum.

Calyx five-leaved.

77 Andrachne, h 2 Italy.

Calyx six-leaved.
78 Agyneia,
$s \quad 2$ China.

* The drug coloquintida or colocinth is the pulp of a species of cucumis, called cucumis colocynthis. 


\section{$\left[\begin{array}{lll}140 & 0\end{array}\right]$ \\ Class XXII. D I QE C I A. \\ (Two houses.)}

This clafs consists of such genera, as have male and female flowers distinct on two separate plants.

$$
\text { O BSERVATION. }
$$

There are many plants which have male and female flowers distinet on two separate rocts, yet are not admitted to this clafs, because they are only species of some particular genus, which agree in all other instances. with the generic character to which they belong; as valeriana, (triandria,) rhamnus, rhus, lonicera, phylica, (pentandria,) rumex, (hexandria,) laurus, (enneandria,) guilandina, cucubalus, lychnis, phytolacca, gopsophila, (decandria.) spircea, rubus, (icosandria.) clematis, thalictrum. (polyandria.) napcea, (monadelphia,) gnaphalium, (syngenesia,) carex, urtica, morus, (monocia).

It may be also observed that none of the species of the rough leaved plants of Ray, in clafs and order pentandria monogynia, or in the clafses didynamia, tetradymamia, and diadelphia have any of the species been found to have distinct sexes on different plants.

This clats contains fourteen orders,

Founded on the number, union, and situation of the stamina, in the male flowers.

\section{ORDER I. MONANDR IA.}

$$
\text { (One male.) }
$$

no. genera. growth. no. of native of species.

1 Najas,

a Pandanus, h 1 Europe.

h i Ccylon. (mostodorous.) 


\section{ORDER II. D I A N D R IA.}

\section{(Truo males.)}

7io. Eenera. growih. no of native of species. Spatha.

3 Cecropia,

4 Vallisneria, ${ }^{*} \quad h$ 1 Jamaica.

Amentum.

5 Salix, $\quad$ t\& h $3^{1}$ Egypt.Lapland. Brit.21

\section{Order III. T R I A N D R I A.}

(Three males.)

$\begin{array}{llll}6 \text { Calurus, } & \text { s } & 2 & \text { E. and W. Indies. } \\ 7 \text { Empetrum, } & \text { s } & 2 & \text { Europe. } \\ 8 \text { Maba, } & \text { s } & \text { i Tonga Tabu. } & \text { Brit. i } \\ 9 \text { Osyris, } & \text { s } & 1 \text { Italy. }\end{array}$

Anentum.

10 Exccecaria,

11 Restio,t s 1 Amboyna.

s 9 Cape, \&c.

ORDER IV. TE T R A N R I A. (Four nalabs.)
12 Hippopha,
$\mathrm{s}$
2 Canada.
Brit. 1 13 Montinia,

* The male vililisuerici being always under water, hath a very short stalk, on the top of which its flowers are produced, and when nearly arrived at maturity, they are separated from the staik, and come unopened to the surface of the water; soon afterwards they expand themselves, and swim about the female flowers, which are blown at the same time. The female flowers have long spiral stalks, which relaxing, permit them to rise to the surface, and remaining there in full drefsed flower, receive the visits of the male; and in a few day's return again under water.

+ Many of the houses at or about the Cape of Good Hope, are covered with a sort of dark colored reed, (restio tellorim). 
no. genera. growth. no. of native of species

13 Montinia,

14 Trophis,

15 Viscum,

16 Batis,

17 Myrica, *

$\begin{array}{lll}s & 1 & \text { Cape. } \\ s & 1 & \text { Jamaica. } \\ s & 9 & \text { Cape. }\end{array}$

Involucrum.

Order V. PEN T A N D R I A. (Five males.)

18 Acnida,

19 Antidesma, 20 Astronium,

21 Canarium,

22 Cannabis,

23 Flevillea,

24 Humulus,

25 Iresine,

26 Pistacia, $\$$

27 Spinacia,

28 Zanonia,

29 Zanthoxylon, h

t

t 1 India.

s 1 Jamaica.

$\mathrm{s} 1$ India.

h. 1 India.

h 2 W. Indies.

h 1

h 1 Virginia. Jamaica.

t 5 Sicily.

h 2 Siberia.

h 1 India. Malabria.

s 2 Virginia. Carolina.
Brit. i

ORDER

* The substance which is ohtained from the candleberry myrtic (mrica) is from the covering of the berries, which is a granulated, white, unctuous substance; which, after twice boiling, becomes a transparent green, and is a medium between wax and tallow.

t A female hemp hath sometimes had one or two male flowers, and consequently good secd, from which some persons have doubted of the scies of plants.

i Hop-binds properly macerated in water, like hemp, will make cloth.

\& Mastiche (a resin) is from the pistacia lentiscus. 


\section{I E C IA.}

\section{ORDER VI. HEXANDRIA.}

\section{(Six males.)}

iio. genera. growth. $\begin{gathered}\text { no. of native of in species } \\ \text { specics. }\end{gathered}$ Calys six-leaved.

30 Dicscorea,

31 Rajania,

32 Smilax,

33 Tamus,

h 9 India.

h 3 America.

s\&h 14 Spain. Ceylon.

h 2 Crete.

Brit. 1

\section{Order VII. OCT A N D R I .}

(Eight males.)

Calyx four-parted, or four-toothed.

34 Margaritaria, $s \quad 1$ Surinam.

35 Rhodiola, h 1 Brit. 1 Amentum.

36 Populus, $\quad t \quad 5$ Italy. Brit. 3

(Nine males.)

Calyx three-leaved.

$\begin{array}{llll}37 \text { Hydrocharis, } & \text { h } & 1 & \\ 38 \text { Mercurialis, } & \text { h } & 5 \text { Africa. } & \text { Brit. } 1 \\ & \end{array}$

\section{Order IX. D E C A N D R I A.}

\section{(Ten males.)}

Calyx five-leaved, or five-cleft.

39 Carica,

4o Coriaria,

41 Kiggelaria,

42 Schinus, s 2 India.

s 2 France.

t 1 Fthiopia.

32 Peru.

ORDER

NOтE. Quafsia, in decandria monogynia, is said more properly to belong to dicecia decandria. 


\section{Order X. DODECANDR I A.}

(Twelve males.)

no. genera. growth. no. of native of in Bpecies 43 Datisca, 44 Euclea, h 2 Crete. 45 Menispermum, s 8 America.

\section{Order XI. P O L Y A N D R I A.}

\section{(Many males.)}

$4^{6}$ Cliffortia, \& 18 Cape, \&c.

47 Hedycarya, 's 1 New Zealand.

Order Xil. MONA D E L P H I A. (One brotherhood.) Stamina united at the base. 48 Adelia, s 3 America. 49 Cifsampelos, h\&s 5 America. 5o Napæa, h 2 Virginia. 51 Taxus, I 2 America. Brit. 2 Male, amentum.

52 Ephedra, … s 2 Spain.

53 Juniperus, * s 10 Barbadoes, China. Br. 1

$$
\text { OrDER XIII. S Y N GENESIA. }
$$

(Confederate males.) Stamina united at the top. Calyx six-leaved.

54 Ruscus, $\quad 5 \quad 5$ Italy. Spain. Brit. 1,

$$
\text { Order xiv. G Y N A N D R i a. }
$$

(Feminine males.)

The stamina growing on a sort of style, or imperfed pistillimen.

$$
\text { Calyx five-leaved. }
$$

55 Clutia, $\quad$ s 9 Africa.

* Olibanum (a gun resin) is from a species of juniperus, called juniperus lycia. 


\section{$\left[\begin{array}{ll}145 & ]\end{array}\right.$}

\section{Class XXIII. POL Y G A M I A.}

\section{(Polygamies.)}

This clafs consists of such genera as have hermaphrndite flower's, and also either male or female flowers, or both, distinct, either on the same, or on different plants. So that to be of this clafs, a plant ought to have some of its flowers hermaphrodite, to distinguish it from those of the clafses monecia, and diacia. Yet there are a few exceptions, as in the third distinction under the second order, and in the third order.

The polygamy of hermaphrodites and males on the same plant, is also ob'servable in several of the umbelliferous plants, (pentan. digyn.) particularly carrot, sanicle, hog's-fennel, coriander, chervil, shepherd's-needle, alisander, bastard-parsley, and carui.-These plants therefore strictly ought to have been arranged under this clafs; but Linnæus more properly judged the natural character to be prevalent.

This clais contains three orders.

\section{Order I. MON E C I A.}

\section{(One house.)}

Having the polygamy on the same plant.

no. genera. growth. no. of native of species. 1st. Male hermaphroaites, and female hermaphrodites.*

Spatha.
1 Musa,
h
3 India.
2d. Herma.

* Called so from the sex that is predominant, as a male hermaphrodite ath the fenale aborsirc or ineffectuai; and female hermaphrodite the mabe. 
no. genera. "growth. no. of necies. native of 2d. Hermaphrodites and males.

$\begin{array}{lrrl}2 \text { Acer, } & \text { t } & 11 & \text { Crete. America. Brit. } 2 \\ 3 \text { Celtis, } & \text { t } & 3 & \text { France. } \\ 4 \text { Fusanus, } & \text { t } & 1 & \\ 5 \text { Gouania, } & \text { s } & 1 & \text { Domingo. } \\ 6 \text { Mimosa, } & \text { s } & 53 & \text { Africa. America. } \\ 7 \text { Ophioxylum, } & \text { s } & 1 & \text { Ceylon. } \\ 8 \text { Solandra, } & \text { s } & 1 & \text { Cape. } \\ 9 \text { Terminalia,t } & \text { s } & 2 & \text { France. E. Indies. } \\ 1 \text { Valantia, } & \text { h } & 8 \text { Europe. } \\ 11 \text { Veratrum, } & \text { h } & 3 & \text { Rufsia. }\end{array}$

Gluma.

12 Fgilops,

h 6 Spain. Italy. Brit.:

13 A ndropogon,

h 23 India. America.

14 A pluda,

15 Cenchrus,

h

4 E. and W. Indies.

16 Holcus,

17 Ischœmum,

18 Manisuris,

19 Spinifex,

h 9 Italy.

h 13 India.

s 2 China.

1 India.

$s \quad 1$ E. Indies.

Umbel'd.

20 Hermas,

h 5 Cape.

Amentum.

21 Brabeium,

s 1 Cape.

3 d. Hermaphrodites and females. 22 Atriplex, h\&s 12 Siberia.

Brit. 2 


\section{POL Y G A M I A.}

no. gencra. growth. nocies. native of species

23 Clusia,

$2 \pm$ Parietaria,

t. 4 America.

h 8 Portu. Crete, \&c. Br. 1

\section{Order II. D I CE C I A.}

(Two houses.)

Having the polygamy on two plants.

1st. Hermaphrodites and males.

25 Chrysitrix, (glume)

26 Diospyros,

27 Nyfsa,

28 Stilbe,

\section{)}

$t 5$

$\mathrm{t}$

29 Panax,

t.

1 Cape.

5 Italy. Virginia.

1. Virginia.

3 Cape.

5 China. America.

\section{2d. Hermaphrodites and females.}

30 Fraxinus, *

31 Gleditsia, + t 3 America.

$t \quad 2$ America.

Brit. 1

\section{$3^{d}$. Androgynous and males.}

32 Anthospermum; s \& 3 Ethiopia.

Umbel'd.

33 Arctopus, h 1 Africa.

No calyx.
34 Pisonia,
$S \underset{U}{2}$ W. Indies.
ORDER.

* Manno is a concreted juice chiefly from a species of ash, called fraximus ormus. This is the sort at present most used, though formerly that obtained from the hedysarum alhagi, was in greatest esteem, called Syrian or Persian manna, which granulated like mastick.

+ In grleditsin, the hermaphrodites and males are on the same plant, and the females on another.

+. Amber trec (anthospermum) is cailed so from its fragrant odour: Real amber being a fosil bitumen. 


\section{Order III. T R I CE C I A.}

('Three houses.)

Having the polygamy on three plants.

220. genera. growth. no. of native of species. Androgynous, male, and female, on three plants.

35 Ceratonia,

36 Ficus, * : $\mathrm{t} 1$ Spain.

S 17 Europe. India.

* Linnæus saith he hath removed ficus (fig tree) from the clafs cryptogamia to the clafs polygamia, being convinced of the stricture of the fructification, the umbilicus of the receptacle in some being open.

Therefore the fruit of the ficus is not a pericarpium, but a receptacle, the interior sides of which support the flowers, which are inclosed within it.

Mr. Lee say's, the flowers in our common fig trees are female only, but that formerly known by the name of caprificus hath male flowers; and another called erinosyne, (which is androgynous) hath both male and female flowcrs distinet, though lodged within the same receptacle: Here then we have the triacious polygamy explained; and if descriptions of De la Hire may be trusted, there are figs which contain hermaphrodite flowers; which makes a fourth habitation for the sexes. 


\section{[149]}

\section{Class XXIV. CRYPTOGAMIA.*}

\section{(Clan estine marriages.)}

This clafs consists of such genera in which the parts of fructification, either from their minutencts, or particular situation, are imperfectly visible, or entirely concealed.

This clafs contains four orders.

$$
\text { Order I. F I L I C E S. }
$$

\section{(Ferns.)}

Containing such plants as bear their fruit on spikes, or in spots or lines on the under surface of the leaves, though sometimes at the root.-It admits of the following character. The calyx, a scale growing out of the lcaf, opening on one side, under which are pedunculate globules, each encompafsed by an elastic ring, which breaking with viclence, scatters a powder. But as there are no certain distinctions in the fruatification sufficient to establish the genera, Linnæus hath arranged them according to the form and situation thereof.

no. genera. growth. no. of native of in Bries. 1st. Fructifications spiked.

1 Cycas,

2 Equisetum,

3 Onoclea,

4 Ophioglofsum,

5 Osmunda,

6 Zamia, s 1 India.

h 7 Europe.

h 2 Virginia.

h. 9 America.

h

s
17 Cape. Ceyl.
Brit. 6

Brit. 1 Brit. 4 2d. Fructi-

* The plants of this clafs are often of dangerous quality. 
no. genera. growth. no. of native of species. 2d. Frutifications on the leaf, beneath.

7 Acrostichum, h 33 N.\& S. Amer. Brit. \& 8 Adianthum, h 27 Africa, \&c. Brit. 9 Asplenium, h 25 America, \&c. Brit. 8 so Blechnum, h 6 Virginia. Japan.

11 Hemionitis, $h \quad 3$ Jamaica.

12 Lonchitis, h 4 Jamaica.

13 Polypodium, h 71 America, \&c. Brit. 25 14 Pteris, h 21 W. Indies. Lrit. 1

15 Trichomanes, h 11 Canary. China. Brit. 2 3d. Frudifications radical.

16 Isoetes,

17 Marsilea,

18 Piluraria,

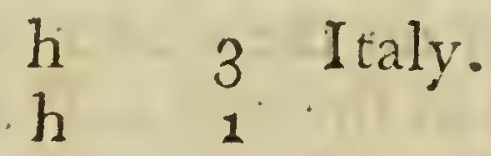

Brit. 1

Biit. 1

\section{ORDER, II. M US S I. \\ (Mojes.)}

These are distinguished according as the anthere (generally without filaments) are or are not under a veil or covering; as they are placed on the same plant with the female, or on a different plant, (called one-ucd. ortwo-beds,) and as the females are aggregate or solitary. This division. Linneus tells us, is according to Delleninis.

After the falling of the outcr veil or covering, the antherce are found to be covered with another little hood, called by Linnaus operculum, which may be considered as a capsulc, or perhaps more properly a receptacic supporting the flower and fruts for within the same little hood in buxbaumia, Linnaus saith he lath observed real anthera hanging by fllaments, opening at the top, and letting fall the pollen, and that the seeds liy at the botrom; but this wants further confrnation, 


\section{R Y P T OG A MIA.}

as the male and female flowers have always been thought to be distinct.

The seeds of mojs are little naked bodies without coat or cotyledon.

no. genera. growth. no. of native of species.

\section{1st. Without calyptra, (a veil).}

$\begin{array}{llrll}\text { ig Lycopodium, } & \text { h } & 27 & \text { Alps, \&c. } & \text { Brit. } 6 \\ \text { 2o Porella, } & \text { h } & 1 \text { Pensilvani., } & \\ \text { \& } 1 \text { Sphagnum, } & \text { h } & 3 \text { Alps. } & \text { Brit. } 3\end{array}$

2d. With calyptra, two-bed.

22 Mnium, h. 24 Europe. Brit. 20 23 Polytrichum, h 5 Alps. Magellan. Brit. 3 24 Splachnum, h 4. Sweden. Brit. 2

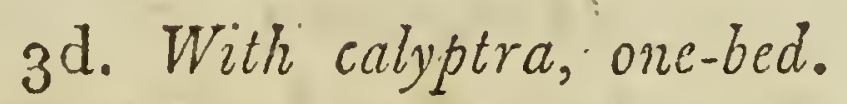

25 Bryum, h 35 Alps, \&c. Brit. 35 26 Buxbaumia, h 2 Sweden. Italy.

27 Fontinalis, $h .4$ Europe. Brit. 4 28 Hypnum, h 47 Europe.Jamaica.Br. 41 29 Phascum, h 5 Europe. Brit. 4

Order III. A L G e e.

(Flags.)

The fruftification of these plants are so obscure, as not to admit of a precise arrangement; the root, stcm, and leaf seem as in one. They are only divided into terrestrial, and aquatic.

Linnaus hath taken his method from Michelius. 1st. Terrestrial.

30. Marchantia, h 7 Eu. W. Indies. Brit. 4 31 Jungermannia, h $3^{\circ}$ Alps, \&c. Brit. $3^{\circ}$ 32 Targionia, h 1 Italy. Brit. 1 33. Anthoceros, 
nr. genera. growth no. of native of species. $\begin{array}{lllll}33 \text { Anthoceros, } & \text { h } & 3 \text { Italy. } & \text { Brit. } 1 \\ 34 \text { Elasia, } & \text { h } & 1 & & \text { Brit. } 1 \\ 35 \text { Rlcia, } & h & 5 \text { Europe. } & \text { Brit. } 4\end{array}$ $3^{6}$ Lichen,* h\&s $113\left\{\begin{array}{l}\text { Lapland. Cape. } \\ \text { Iceland. }\end{array}\right.$ Brit. 37 Byisus, h 14 Italy. brit. 14 2d. Aquatic.

$3^{8}$ Conferva, $\quad$ h 21 Europe. Prit. 21 39 Fucus, $\quad$ h $5^{8}$ Europe. Italy. Brit. 58 4 Tremella,t h 8 Europe. Prit. 8 41 Ulva,

h 15 Europe.

Brit. 15

\section{Order iV. FU N G I. (Fungufses.)}

Cinnæus tells us he rather chose to make his divisions in this order according to Dellenius, than from Michelius; because the first is plain to every one, but the latter requires too nice an inspedion; yet Michelizs hath thrown great light on this tribe of vegetables. as also on mofses and flags. The generic charaeter is therefore only taken from their external forms. They are generally erect.

1st. Hatied. $\begin{array}{lllll}42 \text { Agaricus, } & \text { h } 28 & \text { Europe. } & \text { Brit. } 28 \\ 43 \text { Boletus, } & \text { h } & 14 \text { China. } & \text { Brit. } 13\end{array}$ 44 Hydnum,

* The lichen rangiferimus is the chief food of the rcin-decr in Lapland, duing winter. This plant is very plentiful all over Lapland, and is of a pure white; Nature"s favorite color in the northern regions.

+ That substance that hangs down from the beams in wine vaults, is a species of tremella, which heing dricd becomes a toigh memhranous matte: of a fungus smell; it scems to be of a middle nature between mushroem and star jelly, another'species of tremella. 

no. genera. growth. $\begin{aligned} & \text { no. of necies. native of species } \\ & \text { in Brit. }\end{aligned}$ if Hydnum, 45 Phallus,

h 5 Italy.

h 3 Europe. Brit. 3 Brit. 3

2d. Having no hat.

46 Clathrus,

47 Clavaria,

48 Heluella,

49 Lycoperdon, 50 Mucor,

5 i Peziza, h 4 Siveden. h 8 Europe. h 2

h 17 Bohemia. h 14 Upsal.

h 9 France.
Brit. 4 Brit: 8 Brit: 2 Brit. 15 Brit. 11 Brit. 9 


\section{[ 154$]$}

\section{$\begin{array}{lllllllll}A & P & P & E & N & D & I & X .\end{array}$}

Consisting of such plants, which though capable of being arranged in the several clafses of the system, yet on account of their singular structure, Linnæus hath rather chose to place apart in an appendix, under the head of PALMe, containing such genera, as have a spadix and spatha, (i. e.) whose flowers and fruit are produced, on that particular receptacle or seat called a spadix, protruded from a common calyx in form of a sheath called spatha; and consists of trces and shrubs only.These terms were originally only applied to palms, but now are applied to narcifsus, snowdrop, orchis, Ėc.

\section{P A L M E.* \\ (Palms spathed, three-petal'd.)}

no. genera. growth. $\begin{gathered}\text { no. of native of speciess } \\ \text { in Brit. }\end{gathered}$ 1st. Fan-leaved, (two houses.)

Drupa.

1 Borafsus, s 1 Malabar.

2 Chamærops, s 1 Spain.

3 Corypha, (one house)s 1 India.

2d. Feather-leaved, (two houses.)

Drupa.
4 Elais,
s 1 Guinea.

5 Phœnix,

* Palms have always' a simple stem, not hranched, bearing leaves at the top, resembling those of fern, being a composition of a leaf and a branch, called frondes; and the corolla hath always three petals, or three deep divisions.

It is remarkable that if the male flowers of the palm are got at a proper rime and dried, the pollen will be prolific if kept a year or upwards; and the same hath been observed of the male pistacia. 


\section{A P P E N D I X.}

20. Eenera. growtin no. of native of species 5 Phœuix, $t \quad 1$ India.

(One house.)

$$
\text { Drupa. }
$$
6 Areca,
7 Cocos,
8 Elate,
$t 2$ India.
1. 3 Guinea. India.
$t \pm$ India.

3d. Twice-feaither-leaved, (one house.)

g Caryota, is 1 India.

From the Supplement.

io. Mauritia,

s 1 Surinam.

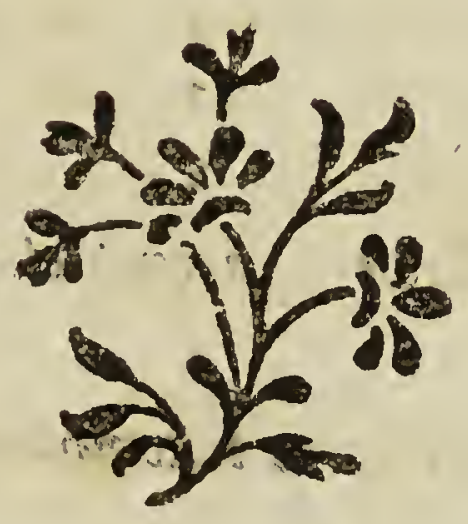

X 2

ADDENDA: 


\section{[ $\left.11_{5} 6\right]$ \\ A $\quad D \quad D \quad E: N \quad D \quad A$ :}

Taken from the fourteenth edition of the Systema Vegetabitia of Linnacus, published at Gottengen by $\mathcal{F}_{0 .}$ Andrea Murray, $1784 . *$

New Genera and number of Species:

genera.

no. of species. native of

D I A N D R I A.-MONOGYNIA.

2d. Flowers beneath, one-petal'd, irregular, fruit capsul'd. Wulfenia,

1 Carinthia.

TR I A N D R I A.MONOGYNIA。

1st Flowers abave.

Witsenia,

1 Maura.

\section{TETRANDRI A.MONOGYNIA。} 8th. Flowers four-petal'd, beneath.
Orixa,
Othera, Skimmia,

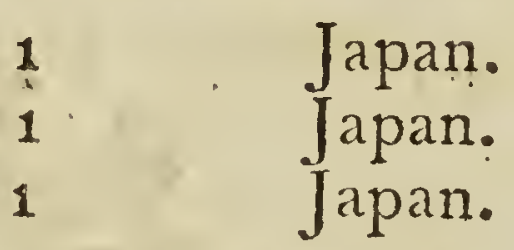

10th. Flowers incomplete, beneath.

Nigrina,

11 th. Flowers incomplete, above.

Gonocarpus,

1

DIGYNIA.

Galopina,

1

PEN:

* The foregoing sheets were printed before this edition was known, or the several new genera and number of species would have been incor porated in their proper places. 


\section{A D D E N D A.}

seneria.

no. of species. native of

P. ENTANDRIA.MONOCYNIA.

1st. Flowers ene-petal'd, beneath, one-seeded. Weigela,

1 Japan.

5th. Flowers one-petal'd, beneath, seed covered.

Capsules.

Dorrena,

1 Japan.

Nigrina is omitted, and a new genus of the same name placed in tetrandria monogynia.

Berries.

Bladhia,

Fagræa,

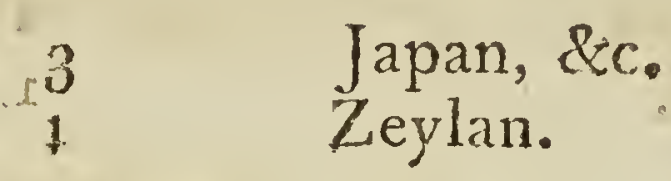

7th. Flowers frie-petal'd, beneath.

Calodendrum,

Hovenia,

Caroxylon,

caps. $x$

Cape.

Elrodendron, caps. 1 seed 1,1

drupe, 1

Cape.

N. B. Argophyllum is placed under the distinction of five-petals above.

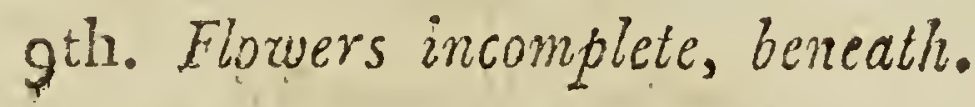

Chenolea, caps. 1

DIGYNYA.

3d. Flowers jeve-petal'd, beneath.

Bumalda,

$$
\text { caps. } 1
$$

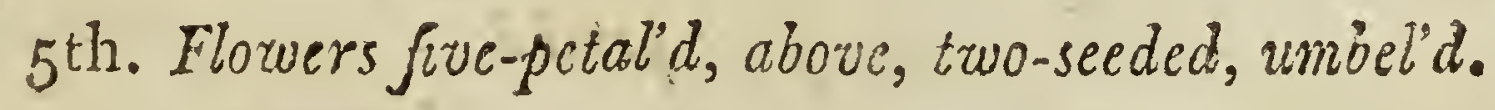

A. With an universal and partial involucre. Vahlia, caps. 1

Cape. 
genera. no. of species. native of

\section{H EX A N D R I A.TMONOOYNIA.}

1st. Flowers calycled, furvished with calyx and corolld. Corols threc-petal'd, or threc-parted.

Lachenalia,

Licuala,
1

1

Corols six-petald, or six-cleft.

Nandina,

Japan.

3d. Flowers naked (without calyx).

Corols beneath, six-petal'd, or six-cleft:

Lindera,

Pollio,

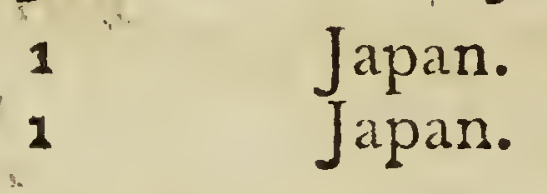

TRIGYNIA.

2st. Flowers beneath.

Wurmbea,

1

Cape.

DE C A N D R I A.MONOCYNIA, $2 \mathrm{~d}$. Flowers many-petal'd, equal.

Ekébergia,

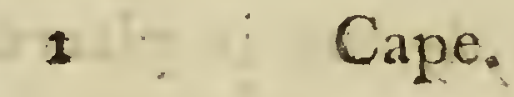

TRIGYNIA。

Capsules three-cell'd.

Deutzia,

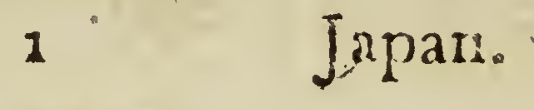

DODECANDRIA-MONOGTNIA:

Corols none.

Tomex,

1 Japan.

Corols four petalid.

Apactis,

4 Japara.

Corols five-petald.

Eurya,

1

Japan.

Caneila 


\section{$A D D E N D A$.}

genera.

no. of species. native of

Canella is substituted for winterania.

POLYANDR I A.MONOGYNIA. 4th. Five petal'd.

Cleyera, calps. 1 Japan.

POLYGYNAA.

Calyx four-leavid.

Hoủtuynia, 1

Wintera is substituted for drimys. Cal. 3 lobes.

TETRAD Y A M I A.LSILIQUOSA. 1st. Calyx closed with leaflets'longitudinally converging.

Chamira, 1

MONADELPHI A.TIRIANDRIA.

Galaxia,

2

EN.NEANDRIA:

Dryandra,

1

POLYANDRIA.

Solandra,

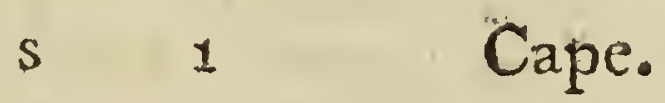

SYN GEN ES I A.-POLYGAMIA TRUSTRANEA。 Receptacle naked.

Sclerocarpus,

1

Africa.

MONCE C I A.-MONANDRIA.

Nipa, spatha, 1

TETRANDRIA.

Aucuba,

1 Japan.

POLY G A M I A.MONECIA.

Fusanus is omitted.

Solandra is omitted, and a new genus of the same name is placed in monadelphia polyandria. 


\section{ADDITIONAL Or LESSER number of SPECIES to several of the GENERA.}

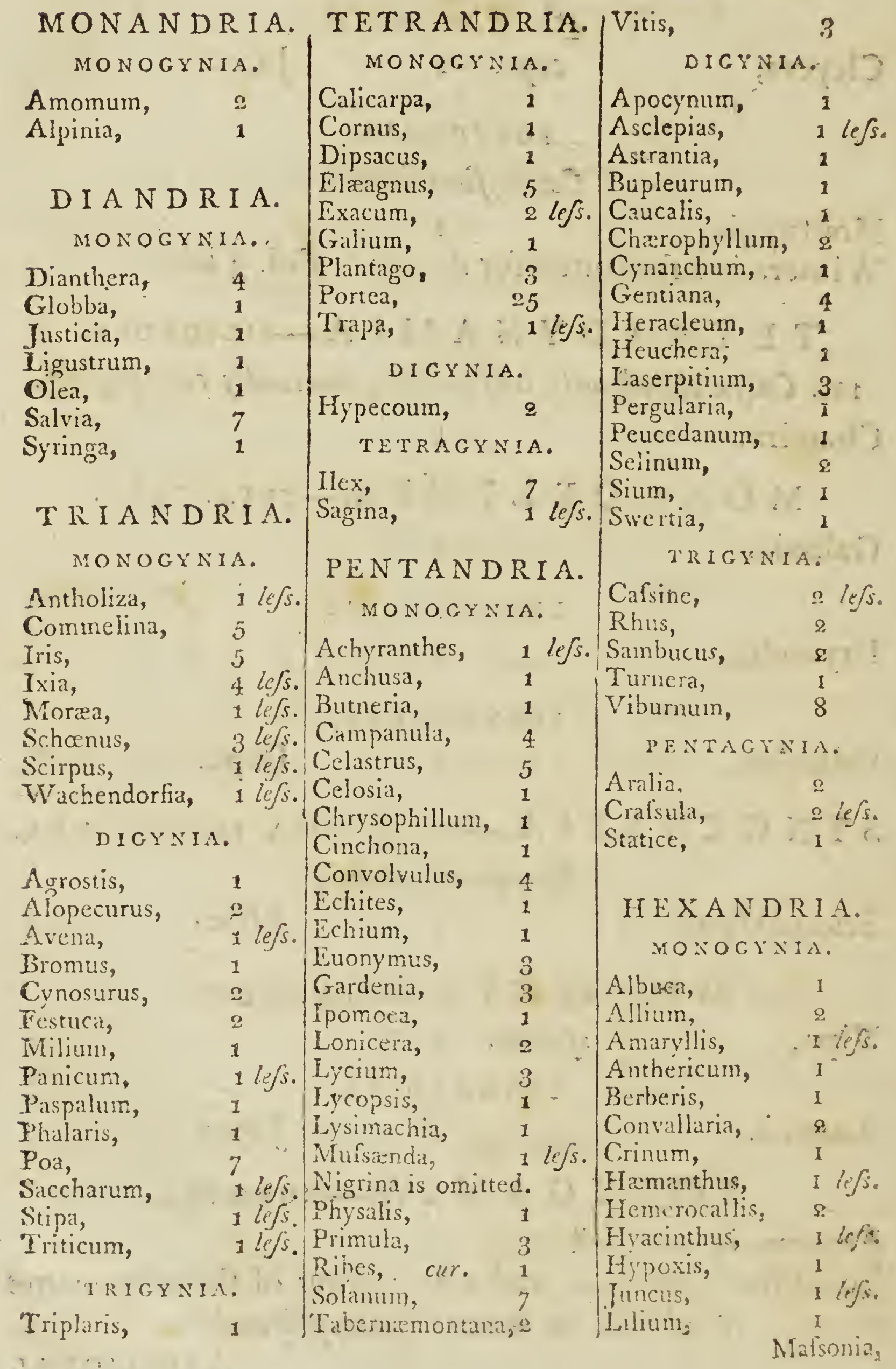




\section{$A D D E N D A$.}

\begin{tabular}{ll} 
Mafsonia, & 1 \\
Ornithogalum, & 3 \\
Orontium, & 1 \\
Pancratium, & 2 \\
Tillandsia, & 2 less. \\
\multicolumn{1}{c}{ TRIGYNIA. }
\end{tabular}

Helonias, I lefs. canella.

Rumex,

2 lefs. Portulaca,

1

HEPTANDRIA.

TETRAGYIA.

Saururus,

$1 \operatorname{legs}$.

OCTANDRIA.

Daphne, MONOGYNIA.

Vaccinium,

TRIGY N I .

Paullinea, 1

Polygonum, 4

EN NEA N DRIA. MONOGY NIA.

Laurus,

4

TRIGYNIA.

Rheuin,

I

D E C A N D R I A. IIONOGYNIA.

Andromeda, Arbutus,

Cafsia,

1 less.

DIGYNIA.

Dianthus,

Gypsophila, $\quad 2$

Saxifraga,

1

2

3

TRIGYNIA.

Silene,

Stellaria,

1

PENTAGYNIA.

Averrhoia,

Cotyledon,

Forskohlea,

Lychnis,

Oxalis,

1
2
1
1
4

4

ICOSA NDRIA.

MONOGYNIA.

Prunus,

7

Myrtis,

DIGYNIA.

Cratægus,

5

PENTAGYNIA.

Mesembryanthemum,

Mespilus,

$1 \mathrm{le} s \mathrm{~s}$

Pyrus,

Spiraa,

Tetragonia,

1 le $/ s$.

1 lees.

$1 \operatorname{lc} \int s$.

D

POLYGYNIA.

Dryas,

Geum,

Potentilla,

Rosa,

Rubus,

POLYANDRIA.

MONOGYNIA.

Actxa,

Chelidonium, 1

Cistus,

Corchorus,

Mammea,

D I G Y I A.

Fothergilla, $\quad 1$

TRIGYNIA.

Aconitum, $\quad 1$

PENTAGYNIA.

Aquilcgia,

1
POI.Y GYNIA.

N. B. The genus drimy's is changed for unintera, $1 \mathrm{le} / \mathrm{s}$. Adonis, $\quad 1 \mathrm{lc} / \mathrm{s}$. Anemone, 3 Atragene, $\quad 1$ Clematis, 2 Ranunculus, 2 Thalictrum, 5

\section{DID Y NAMIA.}

GINNOSPERMIA.

Ajuga, $\quad 1$

Dracocephalum, $2 \mathrm{le} / \mathrm{s}$.

Lavandula, I

Leonurus, 1

Marrubium, I

Mentha, $\quad 2$

Ocymum, $\quad 5$

Phlomis, $\quad$ l lefs.

Sideritis, 2

Stachys, 2

ANGIOSPERMIA.

Antirrhinum, 1

Bignonia, $\quad 2$

Butchnera, I lefs.

Celsia, I less.

Clerodendron, 1

Scrophularia, 1

Digitalis, I lefs.

Gerardia, $\quad 1$

Lindernia, 'I

Pedicularis, $\quad 2$

Ruellia, " 2

Selago, 1 les.

Vitex, I lc/s.

Volkameria, I

TETRADYNAMIA.

SILIQUOSA.

Arabis, $\quad 1$ lefs.

Brafsica, 2

Bunias, I

Chcirantlus, 1

Cleome, $\quad 5$

Crambe, I

$\begin{array}{ll}\text { Sinapis, } & 4 \\ \text { Sisymbrium, } & 2\end{array}$

SIXICULOSA. 
S I I CULOSA.

Draba,

Iberis,

Myagrum,

Thlas pi,

MONADELPHIA.

DECANDRIA.

Geranium,

$$
1
$$

POLYANDRIA.

Camellia,

Hibiscus,

Malva,

Sida,

2
1 le $\int s$
3
3

\section{A DELPHIA.} OCTANDRIA.

Polygala,

$$
1
$$

DECANDRIA.

Astragalus, $\quad 3$

Colutea, $\quad 1$

Cytisus,

Dolichos,

Ebenus,

Glycine,

Hedysarum,

Hippocrepis,

Liparia,

Lotus,

Ononis,

Phaca,

Phaseolus,

Psoralia,

Vicia,

\section{POLYADELPHIA.}

PENTANDRIA.

Theobroma,

$1 \mathrm{leg} s$.

DODECANDRIA.

Monsonia,

1

I COSANDRIA.

Citrus,

$$
1
$$

POLYANDRIA.

Hypericum,

2 Arum,

Picris,

Aster,

Inula, lejs. 1 lefs.

\section{Co}

Viola,
SY NGE N ESIA.

POLYGA. EQUALIS.

Atractylis,

Cacalia,

Carduus,

Eupatorium,

Hieracium,

Lactuca,

Lcontodon,

Prenanthes,

Scorzoncra,

Serratula;

Sonchus,

Spilanthus,

Tragopogon,

POLY. SUPERFLUA.

Achillea

Anthemis,

Arnica,

Artemisia,

Chrysanthemum, 1

Cineraria,

Eclipta,

Erigeron,

Gnaphalium,

Perdicium,

Senecio,

Tufsilago,

Verbesina,

Xeranthemum, 1 lefs. MONOGAMIA.

Corymbium,

G Y N A N

DIANDRIA.

Cypripedium, I

Epidendrum, 1

Limodium,

Ophrys,

Orchis,

Serapias,

POLYANDRIA'。

2 lefs. Dioscorea,

1 lejs. Rajania,

Croton,

Cuprefsus,

Ricinus,

SYNGENESIA.

Bryonia, . 2

Cucumis, I

Cucurbita, I

DI E C I A.

DIANDRIA.

Salix,

TRIANDRIA.

Osyris,

TETRANDRIA.

Myrica,

1

HEXANDRIA.

3

2

EN N E A N D IA.

Mercurialis, 1 lefs.

DODECANDRIA.

Menispermum, 3

MONADELPHIA.

Taxus,

2

POL Y GA M I A.

MONOECIA.

Accr,

6 le $f s$.

6

lefs.

3



A D D E D A.
163

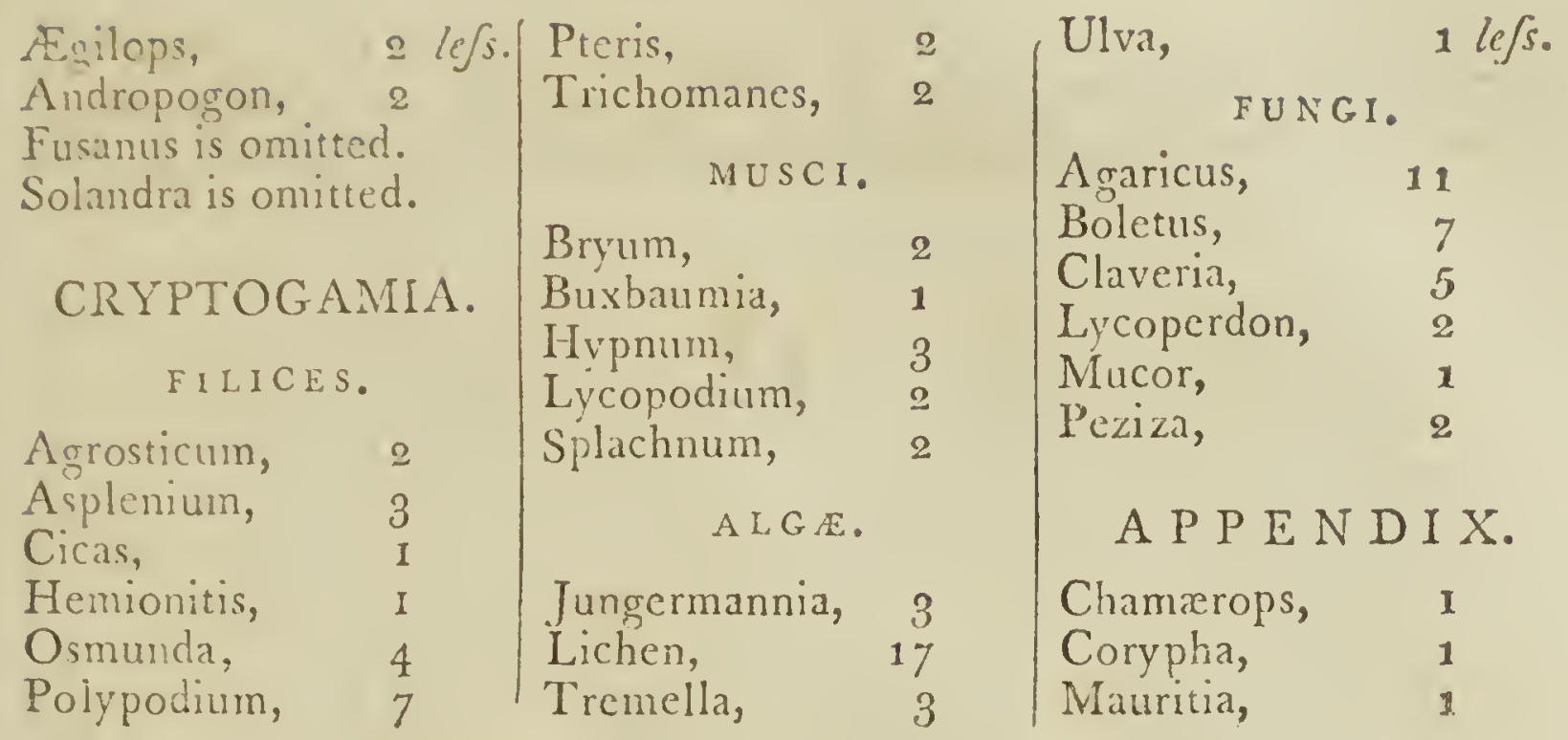

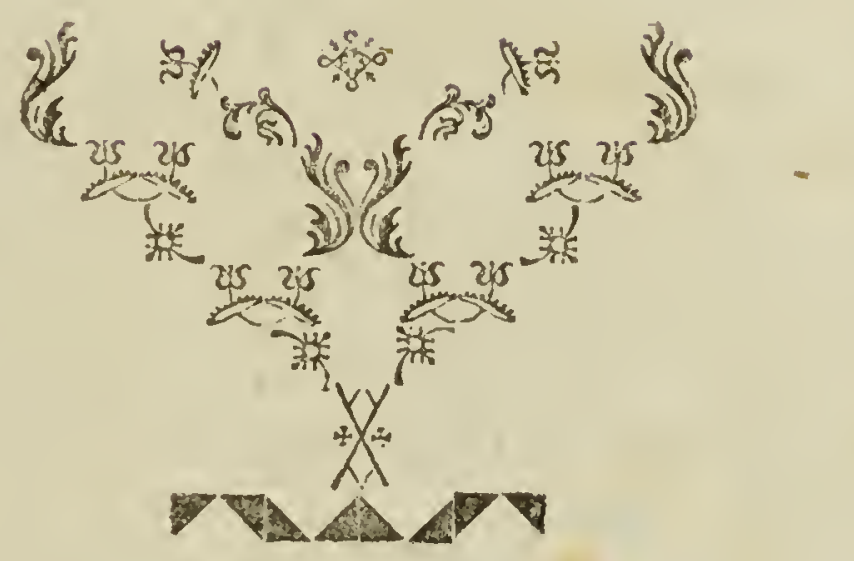





\section{$\left[\begin{array}{lll}165 & \end{array}\right]$}

*Ron

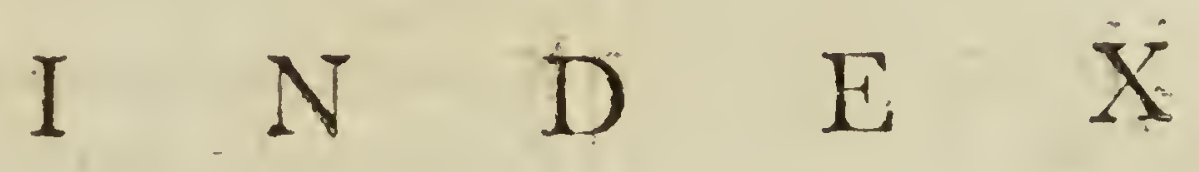

O I I H

\section{G E N E R A}

A 'BRUS

Acaly'pha

Acánthus, Bear's breech 97

A'cer, Maple

Achilléa, Milfoil, Iar:

$$
\text { row }
$$

A'chras, Sapota Achyránthes Achnida, Virginian hemp

Aconítum, Aconite

A'corus, Sweet rush

Acróstichum, Acrostic 150 Actéa, Herb-christopher 91 Adansónia, Ethiopian

Adélia

sour gourd

Adenanthéra, False flower fence Adiánthum, Maiden hair

Adónis, Bird's eye Adóxa, Tuberous mos-
114

55 . E'gilops, Hard grass 146

137 Egiphila 52 Egopódium; Goutwort 66 Egópricon Eschynómene, false sensaitive plant 1 i5 E'sculis, Horse chesnut 74 Athúsa, Lefser hemlock 65 Agáricus, Agaric 152 142 Agáve, American aloe 71 93 Agératum, False hemp

72
agrimiony.

Agrimónia, Agrimony 85 Agrostémma, Campion, or wild lichnis $\quad 82$

Agróstis, Bent grajs 49 Agynéja 139 A'ira, Hair grafs 50 A'juga, Bugle $\quad 9^{6}$ A'izoon 89 \begin{tabular}{r|lr}
150 & Albúca & 71 \\
94 & Alcea, Hollyhock & 108
\end{tabular} Alchemilla, Lady's mantle 54 
$\begin{array}{ll}\text { Alétris } & 71 \\ \text { Alisma, Water plantain } & 73\end{array}$

Allamánda

Alliónia

A'llium, Garlic

57

$5^{2}$

Allophy'llus

A'loe, Aloe

Alopecúrus, Fox-tail

$$
\text { grafs }
$$

Alpinia

Alsine, Chickweed

Alstónia

Alstroeméria

Althæ'a, Marsh mallow 108 Aly'fsum, madwort 104 Amaránthus Amaranth 136 Amary'llis Lilly daffodil 70 Amasónia

Ambróma

Ambrósia

Ambrosínia

Améllus

Amethystéa

Ammánnia

A'mmi, Bishop's weed. Amómum, Ginger

Amórpha, Base indigo 114 Amy'gdalus, Almond,

Peach, Nectarine 88

A my'ris

Anábasis, Berry-bearing

$$
\text { glafswort }
$$

Anacárdium, Acajou, or

$$
\text { cashew nut }
$$

Anacy'clus

Anagállis, Pimpinel

Anágyris, Stinking bean trefoil.

54

64
Anastática, Rose of

Fericho 104

$5^{6}$

Ancístrum 46

70 Andráchne, Baseorpine 139

75 Andrómeda, Base heath 81

$7^{1}$ Andropógon $\quad 146$

Andrósace

Andry'ola, Downy sozwthistle

123

66 Anemóne, Wind flower 94 Androvánda 68

Angélica, Angelica 64

Angúria $\quad 135$

Anéthum, Dill, Fennel 66

Annóna Custard apple 94

A'nthemis, Chamomile 126

Anthéricum, Spider-

117 wort 71

${ }_{13} 6$ Anthistíria $\quad 49$

133 Anthóceros $\quad 152$

126 Antholiza 48

46 Anthospérmum, Amber

Anthoxánthum, Ver-

147

$$
\text { nal grafs }
$$

Anthy'llis Kidney, wetch 114

Anticórus

Antidésma

75

Antirininum Siap 142

Antirrhínum, Snap dragon

Apáctis

99

158

A'phanes, Parsley.piert 55

Aphyllánthes $\quad 70$

Aphytéia $\quad 106$

A'pium, Parsley 66

Aplúda $\quad 146$

$79 \Lambda$ pócynum, Dog's bane 62 A ponogéton 


\section{G $\mathrm{E} N \mathrm{E} R$.}

Aponogéton

Aquirtia

Aquilégia, Columbine

Aquilicia

Arabis, Base tower mustard

ATachis, Ground nut 114 Arália, Berry-bearing angelica

A'rbutus, Strawberry tree

A'retium, Burdock

A'retopus

Aretótis

Arduina

Aréca

Arcnária, Sand-wort

Arethúsa

Arétia

Argemóne Prickly poppy 91

Argophyllum

Aristida, Oat grafs

Aristolóchia, Birth-

$\begin{array}{cc}\text { wort } & 132 \\ \text { A'rnica, Leopard's bane } 125\end{array}$ Artédia

Artemisia, Mugwort, Tormwood

Artocárpus

A'rum, Wake robin dra-

$$
\text { goin }
$$

Arúndo, Reed

A'sarum, Asarabacca

Asclépias, Swallow-uort 62 A'scyrum, St. Peter's wort

Aspálathus, Ajrican broom

123

127

$5^{8}$

155

82

130

60

49

117
74 Aspáragus, Asparagus 71

52 Asperúgo, Small wild

93 buglojs $\quad 5^{6}$

61 Aspérula, Wood-roof 53

Asphódelus, Asphodel 71

Asplénium, Spleenwort

$15^{\circ}$

A'ster, Aster, Starwort 125

Astrágalus, Liquorice, or wilk vetch

115

81 Astrántia, Black master-

147

57

Aucúba

Avéna, Oats

Avérrhoa

64

Astrónium

142

Athamánta, Base spignel 64

Athanásia

Atráctylis, Distaff this-

124

Atrágene

Atrapháxis

A'triplex, Orach

A'tropa, Deadly' night-

123

94

72

146

Avicénnia

Axy'ris

Ayénia

58

159

$5^{\circ}$

82

98

135

132

Aytónia $\quad 106$

Azília, American upright honeysuckle

B

Báccharis, Plowman's

Breckéa

125

76

114 Ballóta, Black horehound 96 Z 2

Baltimóra 
Baltimóra

Banistéria

Bánksia

Barléria

Barnadésia

Barringtónia

Bártsia

Basélla, Malabar nightshade

Báfsia

Bátis

Bauhínia, Mountain ebony

Befária

Begónia

Bẹllis, Daisy

Péllium

Bellónia

Bérbcris, Berverry

Bérgía

Besléria

Béta, Beet

Betónica, Betony

Bétula, Birch

Bidens, Water hemp

$$
\text { agrimony }
$$

Bignónia, Trumpet

$$
\text { תlower }
$$

Biscutélla, Buckler mus-

$$
\text { tard }
$$

Bisérrula

Bixa, Anotta

Bládhia

Blix'ria

Blakéa

Blásia

Bléchnum

Blitum, Blite

\begin{tabular}{r|lr}
127 & Bobártia & 49 \\
82 & Boccónia & 84 \\
54 & Boerháaria & 44
\end{tabular}

98 Bolétus 15 '

123 Bómbax, Silk cotton

107 tree 107

98 Bóntia, Wild olive 100

Borágo, Borage $\quad 56$

66 Boráfsus, Malabar palm 154

85 Borbónia 114

142 Boséa, Yerva mora, or

79 Brabéium, African algolden rod tree $\quad 6_{3}$ mond 146

Bráfsica, Cabbage 103

Bráthys 9.3

125 Bríza, Quäke grafs 50

59 Bromélia, Ananas, or.

69 pine apple 69

82 Brómus, Broom grafs 50

82 Brofsa'a " 57

63 Browállia $\quad 9^{8}$

96 Brownéa 107

136 Brunćlla, şee Prunćlla.

Brúnia 61

Brunsfélsia $\quad 5^{8}$

Bryónia, Bryony 139

Biryum 151

Búbon, Macedonian

10.4

115

$9^{2}$

157 Buidléia 52

52 Bufónia, Toad grafs 55

85 Ḃulbocódium, Spring

152 mountain saffron 70

$15^{\circ}$ Bumálda 157

44 Búniss, Sea roçket 103 
Búnium, Pig nut, or carth mu

Buphthálmum, American ox-eye

Bupleúrum, Hare's ear 64 Burmánnia

Burséra

Butnéria

Bútomus, Flowering rush

Buxbáumia

Búxus, Box

By'lsus

\section{C}

Cacália, Alpine coat's foot

Cáchrys

Cíctus, Melon thistle

Cosalpinia, Brasitebto

Cólamus

Calceolária

Calca

Caléndula. Marigoid

Calla, African armin

Callicárpa, Fohnsonia

Calligonum

Callisia

Callitriche, Star grajs 44

Calodendrum

Calophy'llum

Cúltha. Marsh marigoud 91

Calycinthus

Cambógia

Caméllia

Camerária

Campánula, Bell flower

89
Camphorósma

54

69

$\begin{array}{ll}\text { Canárium } & 142 \\ \text { Canćlla } & 159\end{array}$

$\begin{array}{ll}\text { Canárium } & 142 \\ \text { Canélla } & 159\end{array}$

Cánna, Indian flowering reed

44

Cámabis. Hemp 142

Cápparis, Caper bush 91

Capraria, Sweet weed 99

Capsicum, Guinca pep-

151 per

$13^{6}$ Capura

152 Cardamine, Lady's smock

Carảiospérmum, heart-

$$
\text { seed, or pea }
$$

Cárduus, Thislle.

Círex, Sedge, Cyperus

Carica, Papaw

Carifsa

103

Canlua, Carline thistle 123

Carolinéa

Caróxylon

Carpésium

Cárpinus, Hornbeam 137

Cárthamus, Base saf-

Cárum, Carui, or Caraway

Caryocar

143

Cary'osa

123

Caryosa 155 65 93

Casuarina

Cáfsia, Wild senna

135

107 Cafine Cafsioberrybust 79

58 Cafsyta

58 Cafsy'ta

Castilléia 
Catanánche, Candy lion's foot

Catesbera, Lilly thorn 53 Catínus

Caúcalis, Base parsley 64 Ceanóthus, Néw Fersey tea,

Cecrópia

Cedréla

Celástrus, Staff tree

Celósia, Cockscomó amarauih

Célsia

Céltis, Nettle tree

Cénchrus,

Centauréa, Centuary 126

Centélla

Centúnculus, Chaffieed 52

Cephalánthus, Bution wood

Cerástium, Monse-ear chickweed

Ceratocárpus

Ceratónia, Carob tree 148 Ceratophy'llum, Iornwort

Cérbera

Cércis, Fudas tree

Cerinthe, Honey-wort

C'eropégia

Cestrum,

Chatophyllum, wild chervil

Chálcas

Chamatrops, Du:arf palm, or palmetio 154

Chamira

Cháa

141 60 61 62 99 146

136 52

82 134 137 58 79 56 $5^{8}$ 59 65 80 159 134
Cheiránthus, Stock Fuly flower

Chelidónium, Celandine 3 Chelidónium, Celandine go Chelóne, Humuning bird tree

Chenolea

Chenopódium, Goose-

146 .

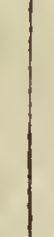

foot, or wild orach 63

Cherléria 82

Chiocócca 60

Chionánthus, Snowdrop tree

Chirónia 45

Chióra Y Thlour centrias. Chondrilla, Gund suc- 70 Chondrília, Gum succory

123

Chrysánthemum, Corn

$$
\text { Marigold }
$$

Chry'sitrix

Chrysobálanus, Cocoa plumb

Chrysócoma, Goldy locks

Chrysógonum

Chrysophyllum, Star

$$
\text { apple }
$$

Chrysosplénium Golten 59 88 124 127 Cicca saxifrage

Cícca

Cicer, Chich peas en 81 Cichórium, Succory, or endive 122 Cicúta, Water hemlock 65 Cimicifuga 93 Cinchóna, Bark tree 59 Cinerária, Sky-flower 125 Cínna Circa'a, Enchanters 


\begin{tabular}{|c|c|}
\hline nightshade & \\
\hline Cifsimpelos $\quad 144$ & Collinsónia \\
\hline ifsus $\quad 54$ & \\
\hline istus, Rock rose & Colútea, Bladder senna: \\
\hline $\begin{array}{l}\text { itharóxylon, Fiddle } \\
\text { wood }\end{array}$ & $\begin{array}{l}\text { Cómarum, Marsh cin- } \\
\text { quefoil }\end{array}$ \\
\hline itrus, Citron $\quad 117$ & $\mathrm{~m}$ \\
\hline lathrus $\quad 153$ & Cométes \\
\hline$\therefore \quad 153$ & melina \\
\hline nia $\quad 60$ & ocládia \\
\hline is. Virgin's bouer 94 & \\
\hline , Base musiard 10 & va, Crow-sike \\
\hline & , Hemlock \\
\hline éndrum & \\
\hline$: 80$ & $\mathrm{Co}$ \\
\hline$\therefore 15 c$ & lária, Lilly of the \\
\hline lium & \\
\hline liffórtia & Convólvulus, $B i$ \\
\hline linopódium, Field & Cony'za, Greater flea- \\
\hline
\end{tabular}

Clitória

Clúsia, Balsam tree

Clútia

Clypéola, Treakle mustard

Copáifera, Balsanin caba-

Coprósma

Córchorus, Jew's mallow

Córdia, Sebesten

Cneórum, Widow wail 48

Cnícus

Coccóloba, Sea side grape

Cochleária, Scurryy

123

Coreópsis Tickseed sun-

81 63 75

54

$4^{8}$

48

67

$5^{2}$

65

07

\section{6} 9 


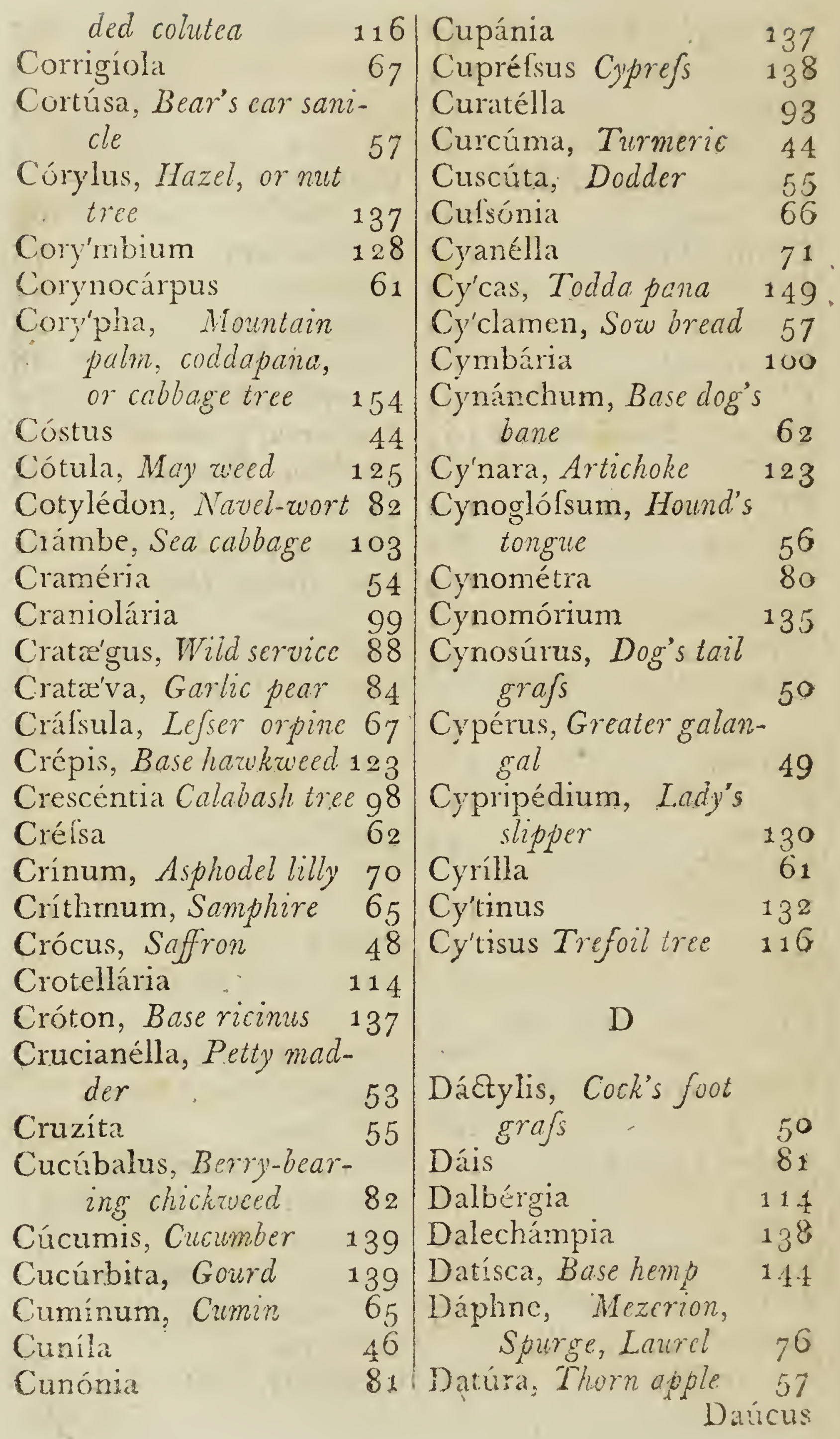


Diucus, Carrot

$64 \mid$ Drimys

Decumária

1)eima

85 Drócera, Studers

93

68

Delphínium, Larkspur

$9^{2}$ Dryandra

159

93 Dry'as $\quad 89$

Deutzia $\quad 158$

Dentiria, Toothwort 103

Dry'pis

Duránia

67

46

Dúrio

Diálium

Duróia

Diánthus, Pink

81

Diapénsia

Dictámnus, Fraxinella 79

Digitális, Foxglove

Dillénia

Diódia

Dionæ'a

Dioscoréa, Indian yam 143

Diósma, African spircea 60 Diospy'ros, Indian date plum

Dípsacus, Teazel

147

$\begin{array}{lr}\text { Dípsacus, Teazel } & 52 \\ \text { Dírca, Leather wood } & 76 \\ \text { Dísa } & 131\end{array}$

Disándra

131

Dodártia

Dódecas

74

99

85

Dodecátheon, Meadia

Dodonæ'a

57

Dólichos, Cow-itch 115

Doræna

Dorónicum, Leopard's bane

Dorsténia Contrayerva

Drúba, Whitlow grafs 54

Dracæ'na

Dracocéphalum, dragon's head

E'benus, Ebony of Crete 114 Echinóphora, Prickly

\section{E}

parsnip 64 Echínops, Globe thistle 128 Echítes

E'chium, Viper's buglofs $5^{6}$

Eclipta

Ehrétia

126

Ehrhárta

Ekebergia

El'xagnus, Wild olive 55

Eleocárpus $\quad 91$

Elæx'is $\quad 154$

E'late $\quad 155$

Elatérium 134

Elatíne, Water wort 77 Elroodendron

Elephántopus

Elephántopus Ele-

Ellísia

phant's foot 128

59

E'lymus, Lime grafs 50

Embothrium 54

E'mpetrum Berry-bearing heath, or crow berries

141

97 Epácris

Dracóntium, Dragons 133 E'phedra, Shrubby horse 


\section{tail}

Epidéndrum, Vanelloe 131 Epigx'a, Trailing arbutus

Epilóbium, Willow herb 75 Epimédium, Barren wort

Eqisétum, Horse tail 149 Eránthemum

Erica, Heath

Erígeron, Lefser flea bane

Erínus

Eriocáulon

Eriocéphalus

Erióphorum

Erithalis

E'rvum, Bitter vetch 116 Ery'ngium, Eryngo, or sea holly

Erythrina, Coral tree 114 Erythrónium, Dog's tooth violet

Erythróxylon

Ery'simum, Hedge mustard

Escallónia

Ethúlia

Eucléa

Eugénia

Evólvulus

Euónymus, Spindletree 61 Eupatórium, Hemp

$$
\text { agrimony }
$$

Euphórbia, Spurge

Euphrásia Eye bright 98

Eurya

E'xacum

61

124

144

88

67
Excocária, Aloes wood 141 F

Fagára

Fagónia

Fagraa

157

Fágus, Beech, Chestnut 137

Faikia

72

Ferrária

Férula, Fennel giant 65

Festúca, Fescue $\quad 5^{\circ}$

Fícus, Fig 148

Filágo, Cotton, or cud weed

Flagellária

127

73

Flevillea $14^{2}$

Fontinális, Water mofs 151

Forskohléa

82

Fórstera

$13^{1}$

Fothergílla

Fragária, Strawberry 89

Frankénia, Seaheath 69

82 Fráxinus, Ash tree 147

Fritillária, Fritillary 71

Fúcus, Wrack, or sea

Fuiréna

152

Fuimária Fumitory 113

49

Fúsanus $\quad$ I 46159

Fúschia $\quad 7^{6}$

G

Galánthus, Snoudrop to Gálax

Galaxia

159

Galéga, Goat's rue 116 
Galénia, Cape jasmine 76/Glúta

Galeópsis, Hedge nettle $9^{6}$ Gly'cine, Kidney bean

Gálium, Cheese rennet 53

Galopina

tree

116

Garcinia, Mangostan 84

Gardénia, Cape ja.mine 60

$G$ aridélla, Fennel flower

$$
\text { of Crete } 82
$$

Gaulthéria, Canadian vine

Cáura, Yellow Virginian

Génipa loose-strife

Genísta, Single-seeded broom

Gentiúna, Gentian

62

Geoffróya

Geránium, Crane’s bill 107

Gerárdia

Geropógon

99

Gesnériá

Gethy'llis

Géum, Avens, or herb bennet

Ghánia

Ginóra

Gisékia

Glabrária

Gladiolus, Corn flag.

122

99

Glycyrrhíza, Liquorice 115

Gmelina

Gnaphálium Tree everlasting, Cudweed 125

Gnétum

Gnídia

138

Gomózia

Gomphréna, Globe amaranth

Gonocarpus

63

Gordónia

Gortéria

Gofsy'pium, Cotion 107

Gouánia

146

Gratiola, Hedge hyssop 45

Gréwia

Grías

133

Griélum

91

82

Grisléa

Gronóvia

75

89

Gúajacum, Lignum vite 80

Guaréa

Guettárda-

75

85

67

118

Guilandina, Nickar tree 79

Gundélia

128

48

Gúnnera

131

Gustávia

Gypsóphila

107

82

Glecóma, Gill, or

Ground ivy acacia

Glinus

1.47

86 Hæmánthus, Blood

Glóbra

Globulária, Blue daisy

47 flower 70

52 Hamatóxylon, Logwood 80

Gloriósa, Suberb liby $7_{1}$ Halésia

$\Lambda \mathrm{a}_{2}$

Halléria, 
Halléria, American fly honeysuckle

Halóragis

Hamamélis, Witch hazel 55

Haméllia

Hartógia

Haselqúistia

Hebenstrétia

Hédera, Iuy

Hedycáryạ

Hedyótis

Hedy'sarum, French honeysuckle

Heistéria

Heliánthus, Sun flower 127

Heliotrópium, Turnsol 56

Heliocárpus

Helicónia

Helictéres, Skrezu tree 132

Helénium, 'Base sum

flower
Helióphila

Hellebórus, Black helle-

$$
\text { bore }
$$

Helónias

Hclvélla

Hemerocíllis, Day lily $7^{1}$

Hemiméris

100

Hemionitis, Mule's fern 150

Heracléum, Cow parsnip 64

Hermánnia

Hermas

Hernándia, Fack in a box

106

${ }_{14} 6$

Hemiaria, Rupture wort 63

Hesperis. Dame's violet 103

Heuchéra, American suritile
Hibiscus, Althaca frutex 108

Hierácium, Hawkweed 123

Híllia

Hirx'a

Hirtélla

69

82

61

Hippia, $\quad 127$

Hippocratéa 48

Hippocrépis, Horse-shoe velch

116

Hippómane, Manchineelr 38

Hippóphae, Sca buck-

$$
\text { thorn }
$$

Hippúris, Mare's tail 44

Hólcus, Indian millet 145

Holósteum

Hopéa

Hórdeum, Barley

Horminum, Pyrcenean

$$
\text { clary }
$$

Hottónia, Water milfoil 57

Hovenia

157

Houstónia

53

Houtuynia $\quad 159$

Hudsónia 84

Hugónia 107

Húmulus, Hop 142

Húra, Sandbox tree ${ }_{13} 8$

Hyacinthus, Iyacinit 71

Hy'dnum 153

Hydrángea $\quad 82$

Hydrástis, Yellow root 94 Hydrócharis, Frog's bit 143 Hydrocótyle, Water navel wort

Hrdrólea

Ifydrophy'llax

Hydrophylum, Water

62

52

$6_{3}$ leif 57

if menat, 


\section{G E N E R A:}

Hymena'a, Locust tree 79 Hyobánche

Hyoscy'amus, Henbane 57

Hóseris, Yellow eye 123

ITypécoum
Hyperioum, St. Fohn's

wiont

Iry'pnum

Hypocha'ris

Hypóxis

Hyfsópus, Hyfsop

\section{I}

Jacquinia

Jambolifera

$$
\text { da } 138
$$

Jasióne, Scabious uith rampion heads, or Sheep scabious

128 Jasminum, fasmine 45 I'beris, Cundy luft, Sci-

İnátia

$$
\text { atica crefs }
$$

I'lex, Holly

Illécebrum, Mountain

Illicium

$$
\text { knob grafs }
$$

Impátiens, Balsan

Imperatória, Master wort

Indigófera, Indigo

Inocárpus

I'nula, Elecampane

Ipumóea, Quamoslit

Irésine

I'ris: Flower de liwe

59

55

62

81 100

Isátis, Hoad

Ischœ'mum

Isnárdia

Isóetes

Isopy'rum

I'tea

I'va, False jesuit's bark.

103

146

55

$15^{\circ}$

94 tree

Júglans, Walnut

136

137

72

151

Júngia 128

Juniperus, funiper 144

Jufsícua 80

Justícia, Beelle nut 55

I'xia 48

l'xora

53

\section{K}

Kærmpféria, Round ze-

$$
\text { doary }
$$

Kátia Dourf lourch 44

\section{4}

Kiggelária

$$
\text { of America } 81
$$

Kleinhóvia

143

Knáutia

Knóxia

Kocnígia

Kúhnia

Kyllingia

$13^{2}$

52

53

53

61

49

L

125 Lachne'a $\quad 76$

57 Lachenalia $\quad 158$

142 Lactíca, Leituce 123

$48 \mid$ Le'tia 
Lagerstra'mia

Lagœecia, Wild or base.

Lagúrus cumin

Lámium, Dead nettle

Lantana, Viburnum of America

Lápsana, Nipplewort 123

Laserpítium, Laserwort 64

Lathreéa

Lathy'rus, Chichling

61

50 Lindera

96 Lindérnia

Limaxa

Linum, Flax

Lipária

Limosélla, Mudwort

Lippia

$9^{8}$

Liquidámbar, Sưeet vetch

115

Lavándula, Lavander 96

Lavatéra, Mallow tree 108

Laugéria

Láurus, Bay

Lawsónia

Lechéa

Lécythis

Lédum, Marsh cistus

I.céa

Lémna, Duck meat

Leóntice, Lion's leaf

Leóntodon, Dandelion 123

Leonúrus, Lion's lail

Lepídium, Diltander

Lercléa

Leucójum, Greater

Lerséra

$$
\text { sinoudrop }
$$

Líchen, Liverwort

Licuala

Ligústicum, Lovage

ligustrum, Privet

Lilium, Lity

Iinćum

Limodórum Base, hellebore
59

78

75

$5^{1}$

92

80

${ }_{13} 6$

135

69

$9^{6}$

104

106

70

126

152

158

65

45

71

74

gum

137

Liriodéndron, Tulip tree

Lisiánthus

Lithospérmum, Grom-

wel

Littorélla

${ }_{13} 6$

\section{er.}

128

Loeflingia

Loesélia

98.

Lolium, Dannel 51

Lonchítis, Rough spleenwort

150

Lonicéra, Honeyurckle 60 Loósa 91

Loránthus

Lótus, Bird's foot tre-

70

foil $\quad 116$

Ludwigia

Lunária, Moonuort 104

Lupinus, Lupine 114

Ly'chnis, Campion $\quad 83$

Ly'cium. Boxthorn 59

Lycopérdon $\quad 153$

Lycopódium $\quad \mathbf{1 5 1}$

Lycópsis

131 Ly'copus, Water hore- 
hound.

Lygćum. Hooded matrieed

I.ysimáchia, Loostrife Ly'thrum, Willow herb

\section{M}

Mába

Macrocnéum

Mahérnia

Málachra

Málope, Base mallow 108

Malpíghia Barbadoes.

\section{cherry}

Málva, Mallow

Mamméa, Mammee

Miangifera, Mango tree 6 . Magnólia, Laurel-beaved

\section{tulip tree}

Manisúris

Mannétria

Manúlea

Maránta, Indian arrozu root

Marcgrávia

Marchántia

Margaritánia

Marrúbium, Horehound 96

Marsiléa

Marty'nia

Mafsónia

Matricária, Feverferw 125

Matthíola

Maurítia

Medéola, Climing African asparagus

Medicágo, Snail trefoil 116 Milléria
118

127

Cow

$9^{8}$

72

Melástoma, American

gooseberry 80

Mélia, Bead tree 80

141

59

68

Meliánthus, Honey flow-

Mélica, Melic, or rope

Melicócca

100

Melifsa, Baulm

$5^{\circ}$

82

Melittis, Base bauln

75

Melóchia

97

97

106

Melódinus 62

Melóthria, Small creep.

Memécylon

48

Menáis

75

59

Menispérmum, Moon-

Méntha, Mint

Mentzélia

$9^{6}$

44

90

151

143

Menyánthes, Bogbean 57

Mercuriális, Mercury 143

Mesernbryánthemum, Fig marigold

88

Méspilus, Medlar 89

Mefserschimídia $\quad 5^{6}$

Mésua, Indian rose chestnut $\quad 108$

Michélia

94

Micropus, Base cudweed

Mílium, Millet 
Millingtónia

Mimósa, Sensative plant

$\begin{array}{rr} & 146 \\ \text { Mimulus, Base foxglove } 99 \\ \text { Mimúsops }\end{array}$

Minuártia

Mirábilis, Marvel of

$$
\text { Peru }
$$

Mitchélla

Mitélla, Base American

Mníarum sanicle

Mníum

Mœhríngia, Mountain chickweed

Mollúgo, African chickweed

Moluccélla, Molucca baulm

Momórdica, Malebalsam apple

Monárda, Osuego tea

Monniéria

Monotrópa, Bird's nest 80

Monsónia

Móntia, Small water chickweed

Montínia

Moræ'a

Morína

Morínda

Morisónia

Mórus, Mulberry tree

Múcor, Mould

Mulléra

Munchháusia

Muntingia

Muriáya

151

$100 \mid$ Músa, Plantain tree 145 Mufsæénda

Mutísia

Myágrum, Gold of pleasure

Mygínda

Myosótis, Mouse-ear

Myosúrus, Mouse-tail 68

Myrica, Candleberry myrtle, Gale, Sweet willow

142

Myriophy'lium, Water milfoil

Myrística, Nutmeg tree 91 Myrósma

Myróxylon

My'rsine, African box

My'rtus, Myrtle

Nájas

140

Náma

Nandina

158

Napiéa

144

Narcífsus, Daffodil 70

Nárdus, Matt grafs 49

Neuráda

Nepénthes

Népeta, Nep, or catmint $9^{6}$

Nephélium

Nérium, Oleander, or rose bay

Nicotiána, Tobacco

Nigélla, Fenne! flower 
Nipa

Nilsólia

Nitrária

Nolána

Nyctánthes, Arabian

\section{jasmine}

Nymphax'a, Water lily 92

$\mathrm{Ny}_{\mathrm{y}}$ 'sa, Tupelo tree $\quad 147$

\section{O}

Obolárias

O'chna

O'cymum, Basil

Oedéra

Oenánthe, Water dropwort

Oenothéra, Tree prim-

Olax

O'lea, Olive

Oldenlándia

Oly'ra

Omphaléa

Onocléa

Onónis, Resl harrow

Onopórdon, Wooly or cotton thislle

Onósma

Ophioglófsum, Adder's

$$
\text { tongue }
$$

Ophiorhiza

Ophiózylum

Ophíra

O'phrys, Twy blade 131

O'rchis, Orchis

Origanum, Wild mar. joram
159

114

85

57

45

\section{Ortégia}

Ory'za, Rice

Osbéckia

97 Osmites

91

97

128

64

75

48

45

53

135

135

149

114

123

57

149

58

146

75

131

97

Orixa

Bethlehem

a.rum

al muriu

Othera

Oriéda

Pxdéria

Pæderóta

Paónia Paony

Pallásia

Pánax, Ginseng

Pándanus

Papáver, Poppy

Páris, True love

Parkinsónia

156

71

Ornithopus, Bird's foot 116

Orobánche, Broom rape 97

O'robus, Bitter vetch 115

Oróntium, Floating

72

48

72

75

Osmúnda, Osmund roy.

Osteospermum, Hard.

seeded chrysanthe-

127

Osy'ris, Poet's Cajsia 141

Othónna, African rag-

$15^{6}$

127

O'xalis, Wood sorrel $8_{3}$

$\mathrm{P}$

93
86

147

Pancrátium, Sea daffodil 70

Pánicum, Panic grass 50

140

Poppy go

Parietária, Pellitory 147

77 
Parnáfsia Grafs of Parna.jsus

Parthénium, Base fever-

$$
\text { fero }
$$

Páspalum

Pafserina, Sparrow wort 76

Pafsiflóra, Pajsion flow-

$$
\text { er }
$$

Pastináca, Parsnep

Patagónula

Pavétta

Paullínia

Péctis

Pedálium

Pediculáris, Lousewort

Pegánum, Wild Syrian

rue

Peltária

Penæ'a

Pentápedes

Pénthorum

Péplis, Water purslain

Perdícium

Pergulária

Perílla

Períploca, Virginian silk 62

Petésia

Petivéria, Guinea henweed

Petréa

Peucédanum, Hog's fennel

\section{Peziza}

153

Pháca, Base milk vetch 115 Phálaris, Canary grafs 50 Phállu's, Stinkhorns. 153 Pharnacéum Phárus
132

66

$5^{8}$

53

77

125

99

99

85

104

52

107

83

125

62

97

53

\section{3}

99

64

(1)
50
53
66
Pháscum

Phaséolus, Kidney bean 115 Phellándriùm

Philadélphus, Syringa 88 Philly'rea, Mock privet 45 Phléum, Cat's tail grass 50 Phlómis, Ferusalem sage 97 Phlóx, Lyclunidea 58 Pho'́nix, Palm, or date tree

Phry'ma

Phyllánthus, Sea side laurel

Phy'lica, Base alaternus 61 Phylláchne

Phy'llis Base hare's car 63 Phórmium 70 Phy'salis, Winter cherry 59 Phytéuma, Rampions 59 Phytolácca, American

\section{nightshade}

Pícris Ox-tongue

83

Pilurária, Pepper grafs $15^{\circ}$

Pimpinélla, Burnet

$$
\text { saxifrage }
$$

66

Pingúicula Butter wort 45

Pínus, Pine tree 138

Píper, Pepper

Piscídia, Dogwood tree 115

Pisónia, Fingrido

147

Pistácia, Pistacia nut $14^{2}$

Pístia, Water houseleek $13^{2}$

Písum, Pea

115

Plantágo, Plantain

Plátanus, Plane tree 137

Plectrónia

Plínia

${ }_{13} 6$ Plukenétia
53 61 88 $13^{8}$ 


\section{G E N E R A:}

Plumbágo, Lead wort 56

Pluméria, Red jasmine $5^{8}$ Póa. Meadow grafs 50 Podophy'llum, Duck's

$$
\text { foot }
$$

Poinciana, Flower fence 79 Polemónium, Greek valerian

Poliánthes, Tube rose Pollio

Polycárpon

Polycnémum

Poly'gala, Milk wort 114 Poly'gonum, Knot grafs 78 Poly'mnia

Polypódium, Polypody 150 Polyprémum, Carolina flax

Polytríchum, Golden maiden hair

Pontedéria
Pommeréula

Pópulus, Poplar

Porána

Porélla

Portlándia

Portuláca, Purslain

Potomogéton, Pond weed

Potentilla, Cinquefoit

Potérium, Gardér burnet

Póthos

Prásium, Shruboy hedge nettle

Prémna

$15^{1}$

49

70

143

62

151

59

85

55

89

137

133

97

98

Prenánthes, Wild let tuce 1 ¿3

Prímula, Primrose
Prínos

Próckia

70

Proserpináca

Prosópis

Protéa, Silver tree

Prunélla, Self-heal

Prúnus, Plum tree

Psídium, Guayava

Psorália

$9^{2}$

$5^{1}$

80

$5^{2}$

97

88

88

115

Psychótria, Ipecacuanka 60

Ptélea, Shrub trefoil 54

Ptéris, Bracken, or brakes

150

Pterocárpus $\quad 115$

Pterónia

124

Pulmonária, Lungruort 57

Púnica, Pomegranate 88

Py'rola, Winter green 80

Py'rus, Pear tree $\quad 89$

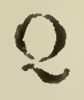

Qúarsia

80

Qúercus, Oak ' 137

Quéria

Quisqúalis

51

80

\section{$\mathrm{R}$}

Rajánia $\quad 143$

Rándia 59

Ranúnculus, Crowfoot, 94

Ráphanus, Radish 103

Rauvólfia

Reaumúria

59

René́lmia

Reséda, Base rocket $\quad 86$

58 Réstio

B b 2 
Rétzia

$58 \mid$ Ruéllia

Rhacóma

Rhámnus, Buckthorn

Rhéedia

Rhéum. Rhubarb

54

61

90

78

Rhéxia

Rhinánthus, Elephant's. head

Rhodiola, Rose-root

Rhizóphora, Kandel of the Indians, mangrove, or mangles 84 Rhododéndron, Dwarf rose bay

Rhús, Sumach, Poison tree

Ribes, Currant and Goofeberry

Ríccia, Marsh liverwort

Richárdia

Ricinus, Palma Christi 138

Ricótia

Rivina

Robinia, False acacia 116

Roéllat

Rondelćtia

Roridula

Rósa, Rose

Rosmarinus, Rosemary

Rótala

Rottboéllia

Royéna, African bladder

$$
\text { nul. }
$$

Rúbia, Madder

Rúbus, Raspbery

Rudbéckia, Dwaiff sun

flower

67

61

152

70

103

54

60

89

46
Rúmex, Dock

Rúmphia

Rúppia, Sea grafs

Rúscus, Knee holly 144

Rufićlia

Rúta, Rue

63

80

\section{S}

Sáccharum, Sugar cane 50

Sagína, Pearl-wort

Sagittária, Arrouihead 137

Salácia $\quad 131$

Salicórnia, fointed

glafsarort

Sálix, Willow

41

Salsóla, Glajurort

141

Salvadóra

Sálvia, Sage, Clary

63

Sámara

Sambúcus, Elder

54

46

$5+$

Samy'da

Round-leaved

60

Sanguinária, Puccoon 9

Sanguisórba, Greater

wild bunet

53

Sanícula, Sanicle 64

Sintalum, Saunders . 54

Santolína Lavender

cotton

124

Sapindus, Soap-berry 77

Saponária, Soap-atort 82

Saráca - 114

Sarithra, Base gentian 67

Samacénia, Side-saddle

127 flower

91 
Saturéja, Savory

Saty'rizin

97 Seguiéria

$9^{2}$

Saurúrus, Lizard's tail 74

sauragesia

Saxifraga, Saxifrage 82

Scabiósa, Scabious

Scabríta

Scávola

Scándix. Eenus's comb,

or shepherd's needle 65

Scherárdia, Little field

\section{madder}

Scheuchzéria, Lefser

$$
\text { flowering rush } 72
$$

Schinus, Indian mastick 143

Schmiedélia

Scho'nus, Rush grafs

Schrebéra

54

Schrophularia, Figwort 99

Schwalbia

Schwónkia

Scilla, Squitl

Scirpus, Rush grafs

Scleránthus, German

$$
\text { knot grafs }
$$

Sclerocarpus,

76

49

62

$9^{8}$

45

71

49

Scólymus, Golden this-

81

159

$$
\text { to }
$$

Scopária

Scopólia

122

53

132

Scorpiúrus Catcroiliars 116

Scorzonéra, Viper's

$$
\text { grafs. }
$$

Scutcllária, Skull-cap

Secále, Rye

Securidáca Halchet vetch
Selágo

$9^{8}$

Selínum, Milk parsley 65

Semecárpus 67

Sempervívum, Houseleek 86

Senécio, Groundsel $\quad 126$

Séptas

74

Serápias, Hellcborine $13^{1}$

Scrpicula

Seríola

136

Seríphium $\quad 128$

Serrátula, Sawuort 123

Scsámum, Oily purging

grain 99

Séscli, Hartwort of Marseiles

65

Sesúvium.

\section{8}

Sheffiéldia

Sibbáldia

$5^{8}$

68

Sibthórpia, Base moneywiort

Sícyos, Single-seeded cu-

99

cumber 139

Sída, Indian mallow 108

Sideritis, Ironwort tree 97

Sideróxylon, Iron wood 59

Sigesbéckia. $\quad 126$

Siléne, Viscous campion 82

Síphium

Sinápis, Mustard

127

Siphonánthuśs

Sirium

54

55

Síson, Base stone parsley 65

Sirm, Water parsnep 65

Sisy'mbrium, Water

$$
\text { crefses }
$$

Sistrinchium, Bermu-

diana

Skimmia 
Skimmia

Sloanéa, Apeiba of the Brasilians

Smilax, Rough bindweed

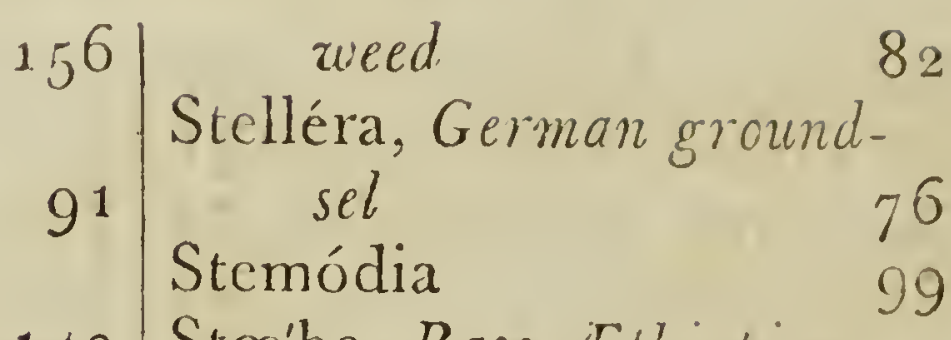

Siny'rnium, Alexanders 65

Solándra

146159

Solánum, Nightshade 59

Soldanélla, Soldanel.

Solidágo, Golden rod

Sónchus, Sow thistle

Sonnerátia

Sophóra

Sórbus, Service tree

Spargánium, Bur reed

Sparmánnia

Spártium, Broom

Spathélia

Spérgula, Spurry

Spermacóce, Button wood

Spxránthus, Globe flower

58

126

123

88

Sto'be, Base AEthiopian

Stercúlia

Stéris

Stewártia

128

Stilágo

$13^{8}$

Stílbe

Stillingia

Stipa, Feather grafs

108

Stratiótes, Water aloe

131

Strúmpfia

147

138

Struthiola

Stry'chnos

50

93

128

54

59

Sty'rax, Storax tree 81

Subulária, Awlwort $10+$

Suriána

83

Swertia, Marsh gentian 62

Swieténia, Mahogany 80

128

Sphágnum, Bog mofs 151

Spigélia, Worm grajs

Spilánthus

58

Spinácia, Spinach

Symphónia

106

Sy'mphytum, Comphry 57

Sy'mplocos 118

Syringa, Litac

Spinifex

Spira'a, Droparort

Spláchnum, Bottle mofs 151

Spóndias, Brasilian plum 83

Stáchys: Base horchound 97 Strehelina

124

Stapélia African suiallow wori

142

146

89

Tabernamontána

58

Tácca

Tagétes, African marigold

Tamarindus, Tamarind tree

Támarix, Tamarisk

Staphyléa. Bladder nut 67 Stálice, Thrift

Stelliria, Gical chick-
67
Támus, Blackbryony 143

'Tanacćtum. Tanscy 125

Tarconántlus. 
Tarconánthus, Shrubly'

African fleabane 124

Targiónia

Tíxus. Yew tree

151

144

Téktona

59

Teléphium, True orpine 67

Terminália

Ternstróemia

Tetrácera

Tetragónia

Teúcrium, Germander

Thalia

${ }_{4} 6$

90

93

89

Thalictrum, Meadow rue 94

Thápsia, Deadly carrot 66

Théa, Tea

Theligonum, $9^{2}$ bage

Theobróma, Chocolate mut

117

Theophrásta

Thésium, Base fuellin 62 Thláspi. Shepherd's

purse

Thouinia

Thryállis

Thúja, Arbor vite 138

Thumbérgia

Thy'mbra, Mountain hys sop

Thy'mus, Thyme

Tiarélla, American sanicle

Tilia, Lime tree

Tilla'a, Small annual houseleek

Tillándsia

Tínus

Toluifera, Balsam of

$5^{8}$

80

100

97

97

55

$7^{8}$ tolu tree

Tomex

$15^{8}$

Tordy'lium, Hartwort

of Crete 64

Torénia

97

Tormentilla, Tormentil 89

Tourncfórtia

59

Tózzia

Trachélium True umbel-

99 liferous throatwort 60

Tradescantia, Virginian

Trágía spider wort

69

Tragopógon, Goat's beard

135

Trápa, Water caltrops 54

Tremélla, Star-jelly $15^{2}$

Tréwia

Triánthema, Horse

$9^{2}$

purslain

Tribulus, Caltrops 80

Trichília 80

104 Trichománes, Tunbridge

maiden hair

Trichosánthes, Serpent cucumber

Trichostéma

139

Tridax, Trailing starwort

Trientális, Winter green with chickweed flowers

74

Trifólium, Trefoil 115

Triglóchin, Arrow-headed grafs

69 Trigonélla, Fenugreek 116

Trílix

Trillium, Three-leaved

90

nighlshade 
$\quad$ nighishade
Triópteris
Triósteum, Fever root
Tripláris
Trípsacum
Tríticum, Wheat
Triumfétta
Tróllius, Globe ranun-
culus

Tróphis

Tropæ'olum, Nasturtion 76

Tulbágia

Túlipa, Tulip

Turnéra, Nettle-leaved cistus

Turræ'a

Turrítis, Tower mistard

Tufsilágo, Colt's foot

'Ty'pha, Cat's tail, or reed mace

\section{U}

U'lex, Furze, Whins,

$$
\text { Gorse }
$$

U'Imus, Elm tree

U'lva

Unióla, Sea side oats

Unóna

of Carolina

U'nxia

Uiéna, Indian mallow

Urtíca, Nettle

Utriculária, Bladder-

$$
\text { wort }
$$

Uvária

Uvulária

72
82

80

108

136
60 Vaccinium, Cranberries 75

51 Vahlia

135 Valántia, Crofsuort 146

51 Valeriána, Valerian 48

85 Valléa 91

Vallisnéria $\quad 141$

Vandellia

99

Varrónia $\quad 59$

Vatéria $\quad 91$

Vática 85

Valézia 62

Vélla, Spanish crefs 104

67 Verátrum, White helle-

146

Verbáscum, Mullein 58

103 Verbéna, Vervain $4^{6}$

126. Verbesina, naked-headed

hemp agrimony 126

Verónica, Speedwell 46 Vibúrnum Pliant mealy

$$
\text { tree }
$$

Vícia, Vetch, Bean 115

Vinca, Periwinkle 58

Viola, Fiolet $\quad 128$

62 Virécta 60

152 Viscum, Mistletoe 142

Visnéa 86

Vítex, Agnus castus 100

Vitis, Vine 61

126 Volkaméria 100

W

46 Wachendórfia

94 Walthéria $\quad 106$

72 Weigela 157

Weinmánnia 
Weimmánnia

Willíchia

Winteránia

Wintera

Witsenia

Wulfenia

Wurmbea

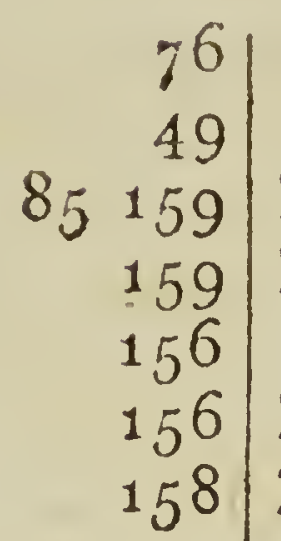

Zámia

Zannichéllia, Tripleheaded pondweed 135 Zanónia 142 Zanthóxylum, Toothach tree Zéa, Indian Turkey $14^{2}$

Xánthium, Lefser burdock

${ }_{13} 6$

Xeránthemum, Austrian sneesewort

Ximénia

Xylophy'lla

Xylópia

$\mathrm{X}^{\prime}$ 'ris

$\mathrm{Y}$

Yúcca, Adam's needle
125

75

66

133

49 wheat

Zizánia $\quad 13^{6}$

Rizóphora, Syrian field basil 46

Zœgæ'a

Zostéra, Grafs wrack 133

Zygophy'llum, Bean caper

80

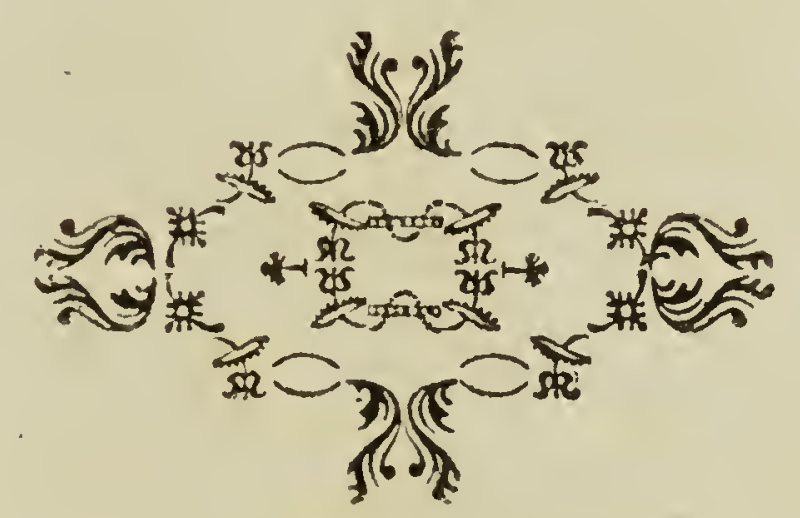





\section{[. 191$]$}

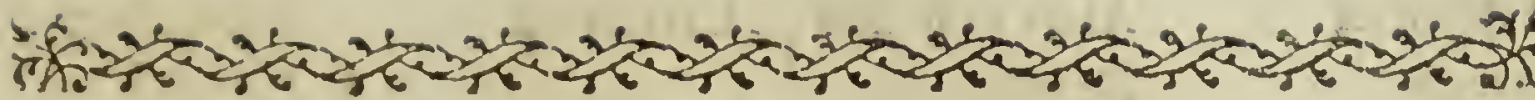

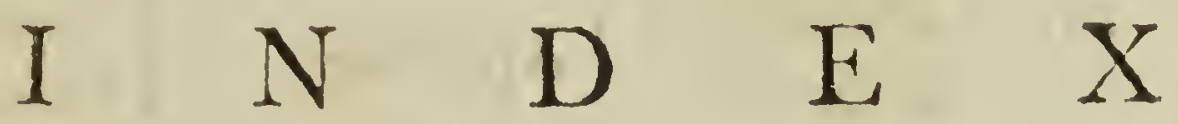 \\ O F S U C H \\ T R I V I A L N A M E S}

A S W E R E T H E

GENERA OF OLD AUTHORS.

A

Acicanthéra Rhexia

Acmélla Spilanthes

Adhadóta Fusticia

Adiántum , Asplenium

E'gilops Quercus

Eginétia Orobanche

Ethiopis Salvia

Agállocha Excoecaria

Agástachys Carex

Agératum Achillea

Agéria Paderota

Agnus Castus Vitex

Agrimonoídes Agrimonia

Ahóvai

Corbera

Ajácis

Aizóon

Delphinium

Alatérnus Rhamnus

A'lcea Malva

Alhági

Alkekéngi Physalis

Alliária

$\mathrm{C} \mathrm{c}_{2}$

A'cinos

Thymus

Illecebrum

Adelia

Acídoton

Mclastoma

Ally'sion 
Ally'lson

Alnus

Alopecúrum

Alsinástrum

Altáica

Aly'pum

Amalágo

Amaranthoides Axyris

Amarélla

Gentiana

Amelánchier $\left\{\begin{array}{l}\text { Mespilus } \\ \text { Pyrus }\end{array}\right.$

Amellóides

Cineraria

Améllus

$\left\{\begin{array}{l}\text { Calea } \\ \text { Aster }\end{array}\right.$

A'mmi

Ammódytes

Amómum

Sison

Ampelóprasum Altium

Amsónia

STaberne-

Imontana

Anacámpse- $\{$ Sedum ros

Anagállis

Anánas

Anándria

A'nblatum

Andráchne

SPortulaca

Veronica

Andrógynus

Bromelia

Tufsilago

Lathrcea

Arbutus

Androsámum Hypericum

Androsáceus Agaricus

Angúina

Angúria

Trichosanthes

Anísum

Anserína

Cucumis

Pimpinella

SPotentilla

Antirrhi-

num

Anteuphórbium Cacalia

Anthélnia

Spigclia

A'nthora
Anthriscus
Aparine
A'phaca
Aphtósus
A'pios

Aconitum

$\{$ Tordylium

Scandix

\{ Galium

Valantia

Lathyris

Lichen

Suphorbia

Glycine

A'pula

Aquifólium Ilex

Arbor tristis Nyctanthe's

Archangélica Angelica

Arctostáphylos Vaccinium

Aréira

Schinus

Arenária

Stellaria

Argemóne Papaver

Argúsia Mefserschimidia

A'ria

Arísarum

Aristélla

Aritúrus

Armeníaca

Cratcegus

Arum

Slipa

Scrophuiaria

Prinuts

Statice

Arrnéria

Armorária

SDianthus

Silene

Cochlearia

Arúncus

Asclépium

Ascolónicum

A'scyron

Alsafoétida

Spirexa

Thapsia

Allinon

Hypericum

Ferula

Asteríscus

Atamásco

Athanásize

Atríplicis

Aulbétia

Silphinm

Amaryllas

Othonna.

Chenopodium

Verbena

Aurántium
Cirrts Aurícula 


$\begin{array}{ll}\text { Auricula } & \left\{\begin{array}{l}\text { Primula } \\ \text { Pcziza } \\ \text { Auriculária }\end{array}\right. \\ \text { Hedyotis } \\ \text { Avellána } & \text { Corylus } \\ \text { Azadiráchta } & \text { Melia } \\ \text { Azárolus } & \text { Cratcegus } \\ \text { Azédarach } & \text { Melia }\end{array}$

B

Badúcca
Baómyces
Bróthryon
Balánghas
Balsámea

Balsámina

Balsamíta

Bámbos Barba Jovis Barbáred Báromez Bartrámia Basílieum Báfsii Batátas Beccabúnga

Béhen

Capbaris Lichen Scirpus Sierculia Pinus SImpatiens Momordica STanacetum $\{$ Chrysanthemum Toluifera Arundo Anthyllis Erysimum Polypodium Triumfetta Ocymum Ambrosinia Convolvulus Veronica $\left\{\begin{array}{l}\text { Cincubalus } \\ \text { Silene } \\ \text { Centaurea }\end{array}\right.$ Belladónna Bellidástrum $\left\{\begin{array}{l}\text { Doronicum } \\ \text { Osmies }\end{array}\right.$ Bénghas Gluta
Benjamína Ficus Bénzoe Croton Bénzoin $\left\{\begin{array}{l}\text { Laurus } \\ \text { Terminalia }\end{array}\right.$ Bergána Erica Bermudinum Sisyrinchium Bernárdia Adelia. Bétle Betónica Fusticia Betúlinum Egopricon Bétulus Carpinus Bídens Coreopsis Bíhai Heliconia Bilimbi Averrhoa Bistórta Polygonum Blattária Verbascum

Blattarioídes Hieracium Bléchnum Ruellia Blítum Amaranthus Bona Nox $\left\{\begin{array}{l}\text { Ipomoea } \\ \text { Smilax }\end{array}\right.$ Bonaróta Pederota Bónduc Guilandina Bonduccélla Guilandina Bonus Hen-\{ Chenopodirícus. $\{u m$

Borbónia Laurus

Bosvalléa Verbesina

Botryápium Pyrus

Bótrys $\quad\left\{\begin{array}{l}\text { Chenopodi- } \\ \text { um }\end{array}\right.$

Bovísta Lycoperdon

Bourréria Ehretia

Bréynia Capparis

Británnica Rumex

Brizoídes Poa

Bruniades Protea

Bryántha 
Bryántha

Bryópteris

Búceras

Bulbocástanum Bunium

Bulbocódi-

$\left\{\begin{array}{l}\text { Ixia } \\ \text { Narcifsus }\end{array}\right.$

Búniùs

$\left\{\begin{array}{l}\text { Aithusa } \\ \text { Stilago }\end{array}\right.$

Bursa Pastóris Thlaspi

C

Caapéba

Cacáo

Cájan

Caínito

Cákile

Cálaba

Calabúra

Calamagnóstis

Calamintha

Cálamus

Calceoláría

Calcéolus

Calcitrápa

Caléndula

Callicórnia

Callocócca

Caly'cina

Cámara

Cámmarum

Campánula

Campechiánum

Campechiénse Solanum

Cámphora

Cándel
Cifsampelos

Theobroma

Cytisus

Chrysophyllum

Bunias

Calophyllum

Muntingia

$\{$ Agrostis

Arundo

Melissa

Acorus

Viola

Cypripedium

Centaurea

Aretotis

Leysera

Cordia

Festugo

Lantana

Aconitum

Canarina

$\{$ Itematoxy-

Slum

Laurus

Rhizophora
Candelábrum Ceropegia

Canélla

Winterana

Cannábina $\left\{\begin{array}{l}\text { Althaa } \\ \text { Tragia } \\ \text { Urtica } \\ \text { Datisca }\end{array}\right.$

Cantábrica Convolvulus

Cantaréllus Agaricus

Capíllus Vè- Adianthum

Caprifólium Lonicera

Cáput Gálli Hedysarum

Cáput Medúsæ Euphorbia

Caracálla Phaseolus

Caragána Robinia

Carámbola Averrhoa

Carándas Carifsa

Cardamínes Lepidium

Cardamómum Amomum

Cardiaca Leonurus

Cardinális Lobelia

Carduélis Arctivin

Carduncéllus Carthamus

Cardúnculus Cynara

Cárica Ficus

Carclinum Menispermum

Caróta Daucus

Carpática Campanula

Carpineus Lichen

Carui Carum

Caryophy'llus Dianthus

Caroliniána Verbena

Carpóbolus Lycoperdon

Cascarilla Croton

Cálsia Laurus

Cafsine Ilex

Cafsinóides Fiburmum

Castánea
Fagus

Catálpa 


\begin{tabular}{|c|c|c|c|}
\hline Catálpa & Bignonia & Chamæsy'ce. & Euphorbia \\
\hline & Terminalia & Chamcepénse & e Stahelina \\
\hline Catária & Nepeta & Chamoemórus & as Rubus. \\
\hline Cátechu & $\begin{array}{l}\text { Mimosa } \\
\text { Areca }\end{array}$ & $\begin{array}{l}\text { Chamomílla } \\
\text { Champáca }\end{array}$ & $\begin{array}{l}\text { Matricaria } \\
\text { Michelia }\end{array}$ \\
\hline Cédrus & & Charácias & Euphorbia \\
\hline & Bombax & Charántia & Momordica \\
\hline Celc & Ircsine & & Cucumis \\
\hline Cénrbra & Pinus. & Ché & Cheiranthus \\
\hline Centauréum & & ánthus & Manulea \\
\hline (2) & ina & oda & Marchantia \\
\hline Centauroídes & & Chína & Smilax \\
\hline Cépa & $\begin{array}{l}\text { Centaurea } \\
\text { Allium }\end{array}$ & $\begin{array}{l}\text { Chinénsis } \\
\text { Chirónium }\end{array}$ & $\begin{array}{l}\text { Valeriana } \\
\text { Laserpitium }\end{array}$ \\
\hline $\mathrm{Cet}$ & Sedu & óxylon & Laurus \\
\hline Cérasu & Prunus & Chordorrhíza & Carex \\
\hline Ceratoídes & Axyris & Chrysán- s & SRhododen- \\
\hline Ceratónia & Mimosa & & \\
\hline Cerefólium & Scandix & ógonum & n Leontice \\
\hline Cérnuum & Carpesium & úlia & Myrtus \\
\hline Cérris & Quercus & Cíc & Astragalus \\
\hline Cervária & Athamainta & & Lathyrus \\
\hline Cerviána & Pharne & ácea & Centaurea \\
\hline Cervicária & $\mathrm{Cam}_{t}$ & Cís & Beta \\
\hline Cervínum & Lycoperdon & Cine & Centaurea \\
\hline Céterach & Asplenium & nómum & n Laurus \\
\hline Chamxbúxus & Polygala & Cisto & Tribulus \\
\hline Chamæcistus & Rhododendron & Citr & Cucurbita \\
\hline xocrísta & & Clandestína & Lathrcaa \\
\hline$r_{\mathrm{Y}}$ & 206 & Cláva hérculis & s Zanthoxylum \\
\hline & & Clavé & Achillea \\
\hline Chamx'drys & Teucri & & unda \\
\hline Chamæjásme & Stellera & Cly'menum & \\
\hline Chame'lea & Tragia & Cneórum & vulus \\
\hline Chama is & $\begin{array}{l}\text { Allizim } \\
\text { Alims }\end{array}$ & Cób & Rhus \\
\hline & Tenicrinm & Coccifora & Quercus \\
\hline
\end{tabular}

Cóculus 
Cóculus

Coeli Rósa

Menispermum

Co'cius Agrostemma

Colicafia Rubus

Colocy'nthis

Arum

Cólpoon

Colubrina

Colúrna

Comaáurea

Comínia

Conoídes

Consólida

Contrajérva

Cucumis

Convólvulus

$\left\{\begin{array}{l}\text { Euonymus } \\ \text { Thesium }\end{array}\right.$

Stychnos

Conyzoídes

Copállinum

Corylus

Chrysocoma

Rhus

Silene

Coracánus

Delphinium

Dorstenia

Corállinus

Polygonum

Corallodéndrum Erythrina

Coralloides Ageratum

Rhus

Corallorhíza

Cynosurus

Cordifólia

Clavaria

Coriária

Ophrys

Coríndum

Cifsus

Rhus

Córis

Coronária

cardiospermum

Corónopus

Corylifúlia

Cóta

Hypericum

Agrostemma

Cótinus

Cuchlearia

Psoralea

Cotoneáster

Cótula Anthemis

Cotylédon

Coúrbaril

Crácca

Rhus

Crísta

Mespilus

Anthemis

Saxifraga

Hymenaa

Vicia

Crista Cosalpinia
Crista Castrénsis Hypnum

Crísta Gálli

Shinanthus

Erithrina

Hedysarum

Crocátus Lichen

Crocody'lium Centaurea

Crofsopétalum Rhacoma

Cruciáta Valantia

Crupína

Centaurea

Crux Andréxe Ascyrum

Crux Córvi Panicum

Crux Gálli $\left\{\begin{array}{l}\text { Panicum } \\ \text { Cratogus }\end{array}\right.$

Cúbeba

Cuculária

Piper

Cucullária

Valantia

Cujéta

Culílaban

Fumaria

Cunónia

Cuphéa

Cúrcas

Curúru

Crescentia

Cy'anus

Cycádis

Cydónia

Laurus

Antholyza

Lythrum

Fatropa

Paullinia

Cymbalária Antirrhinum

Cyminum Cuminum

Cynápium Ethusa

Cynaroídes Protea

Cynocrámbe Theligonum

Cynophallóphora Capparis

Cy'nops

Cynósbati

Cyparifsias

Cytisoídes

Plantago

Ribes

Euphorbia

Anthyllis

D

Dabóecia 
Dáctylon

1) aléa

Dalibárda

Damascéna

1) amasónium

Dandelion

Dens Cánis

Dicera

Dickámnus

Diervílla

Disérmas

Dónax

Dória

Dorónicum

Dortmánna

Dory'cnium

Dríba

Dráco

Dracóntium

Dracúnculus

Drakéna

Dryméia

Dryópteris

Dudáiom

Dulcamára

\section{E

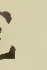

E'bbenum

E'benus

E'bulus

Ecbólium

Echinus

Echioídes
Panicun

$\left\{P_{\text {soralea }}\right.$

Eupatorinm

Rubus

Nigella

Alisma

Tragopogon

Erythronium

Elaocarpus

Origanum

Lonicera

Salvia

Arundo

\} Senecio

Lobelia

SConvolvulus

\{ Lotus

Cochlearia

$\{$ Draccena

Pterocarpus

Arum

$\left\{\begin{array}{l}\text { Artemisia } \\ \text { Arum }\end{array}\right.$

Dorstenia

Carex

Polypodium

Cucumis

Solanum

Diospyros

Aspalathus

Sambucus

Fusticia

Statice

Picris. $\mid \begin{aligned} & \text { Eglantéria } \\ & \text { Elatérium } \\ & \text { Elatine }-\end{aligned}$

Rosa

Momordica

$\left\{\begin{array}{l}\text { Antirrhi- } \\ \text { num }\end{array}\right.$

Elégia

Elemífera

Eléngi

E'lephas

Ellísia

Elutéria

E'mblica

E'mbolus

E'merus

Endivia

Entáda

Ephémerum Lysimachia

Epidéndrum Lycoperdon

Epiglóttis Astragalus

Epipáctis Astrantia

Epipogium Satyrium

Epithymum Cuscuta

Eragróstis $\left\{\begin{array}{l}\text { Poa } \\ \text { Briza }\end{array}\right.$

Erinácea Anthyllis

Erínus

Eriópila

Erisíthales

Erisithales Cnicus

Erúca

Erucágo

Erucástrum

Eruláceum

Ervila

Ery'siphe

Erythrína

E'sculus

Esúla

$\mathrm{D} \mathrm{d}$
SCampanula.

$\{$ Lobelia

Duroia

Brafica

Bunias

Brafsica

Laserpitium

Ervum

Mucor

Piscidia

Quercus

Euphorbia Euódia 


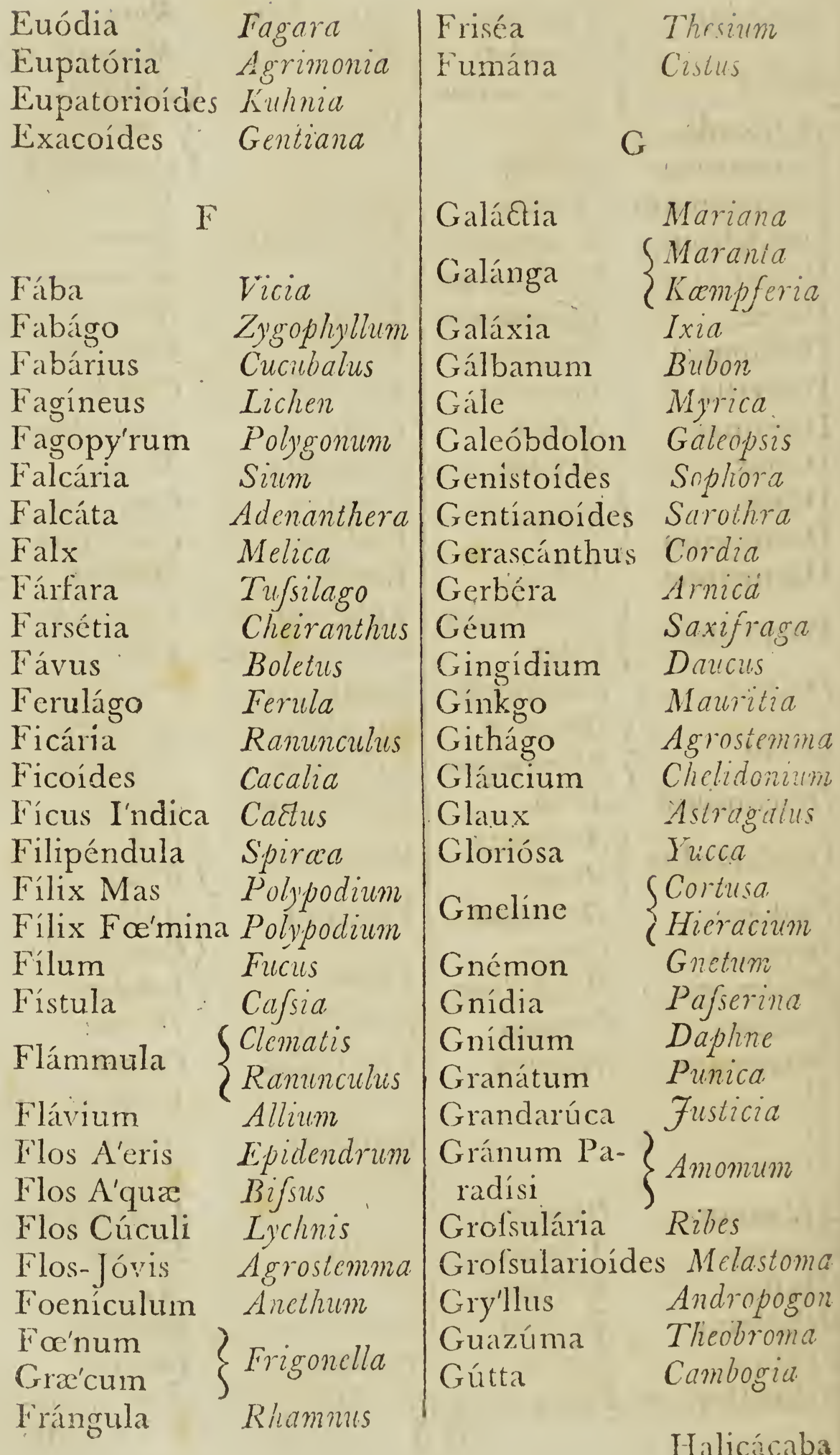


Halicícaba

lialicácabum $\left\{\begin{array}{l}\text { Cardiosper }- \\ \text { mum }\end{array}\right.$

llatimoides

Portulaca

Hailimus

Halléri Atriplex Arabis

Halodéndron Robinia

Hámuala

Peganum

Hóspan

Coperus

Hedy'pnóis

Hyoseris

Heistéria

Hcléninm

Polvgala

Inila

Heleonástes

Carex

Heliánthemum Cistus

Hélix

$\left\{\begin{array}{l}\text { Hedera } \\ \text { Salix }\end{array}\right.$

Hemionitis

Hepática Asplenium Hérba Vénti Phlomis Hieracioídes Picris Hippo-cástanum Rsculus Híppo-márathum Seseli Hirculus Saxifraga

Holoschóenus Scirpus

Holóstea Stelleria

Ilorminum

Saluia

Hóspita Klcinhovia

Hyacinthoides Aletris

Hybanthus Viola

Hydnóra

Aphyleia

Hydrópiper $\left\{\begin{array}{l}\text { Polygonum } \\ \text { Hlingen }\end{array}\right.$

Hypericoídes Ascymin

Hypnoídes

Bryam

Hypocístis

Cytinus

Hypoglólsum $\left.\begin{array}{l}\text { Hypophyllocar- } \\ \text { podéndrum }\end{array}\right\}$ Prolea

Hypophy'llum Ruscus

Hypópithy's Monotropa

Hypóxilon Clavaria

Hylsópifólia Lythrum

Hysteróphorus Parthenium

Hy'strix $\left\{\begin{array}{l}\text { Aristida } \\ \text { Elymus } \\ \text { Barleria } \\ \text { Aspalathus }\end{array}\right.$

I

Jabotápita Ochna

Jácea Centaurca

Jacobáa S Senecio

Lotus

Convolvalus

Jalápa $\left\{\begin{array}{l}\text { Mirabilis } \\ \text { Fabopa }\end{array}\right.$

Jénipha fatropa

Júmbos Eugenia

I'beris Lepidium

Icágo Chrysobalames

I'lex Ouercus

I'nga Mimosa

Inophy'llum Calophyllum

Inscetórius Rhammus.

I'ntsia Mimosa

I'ntybus Cichoreum

Jolithus Byjsus

Jonquílla Narcifsus

Jonthláspsi Clypeola

Ipecacuánhæ $\left\{\begin{array}{l}\text { Euphorbia } \\ \text { Viola }\end{array}\right.$

I'ria Cyperus

I'rio Sisymbriun

Ischácmum Andropogon

D d 2 


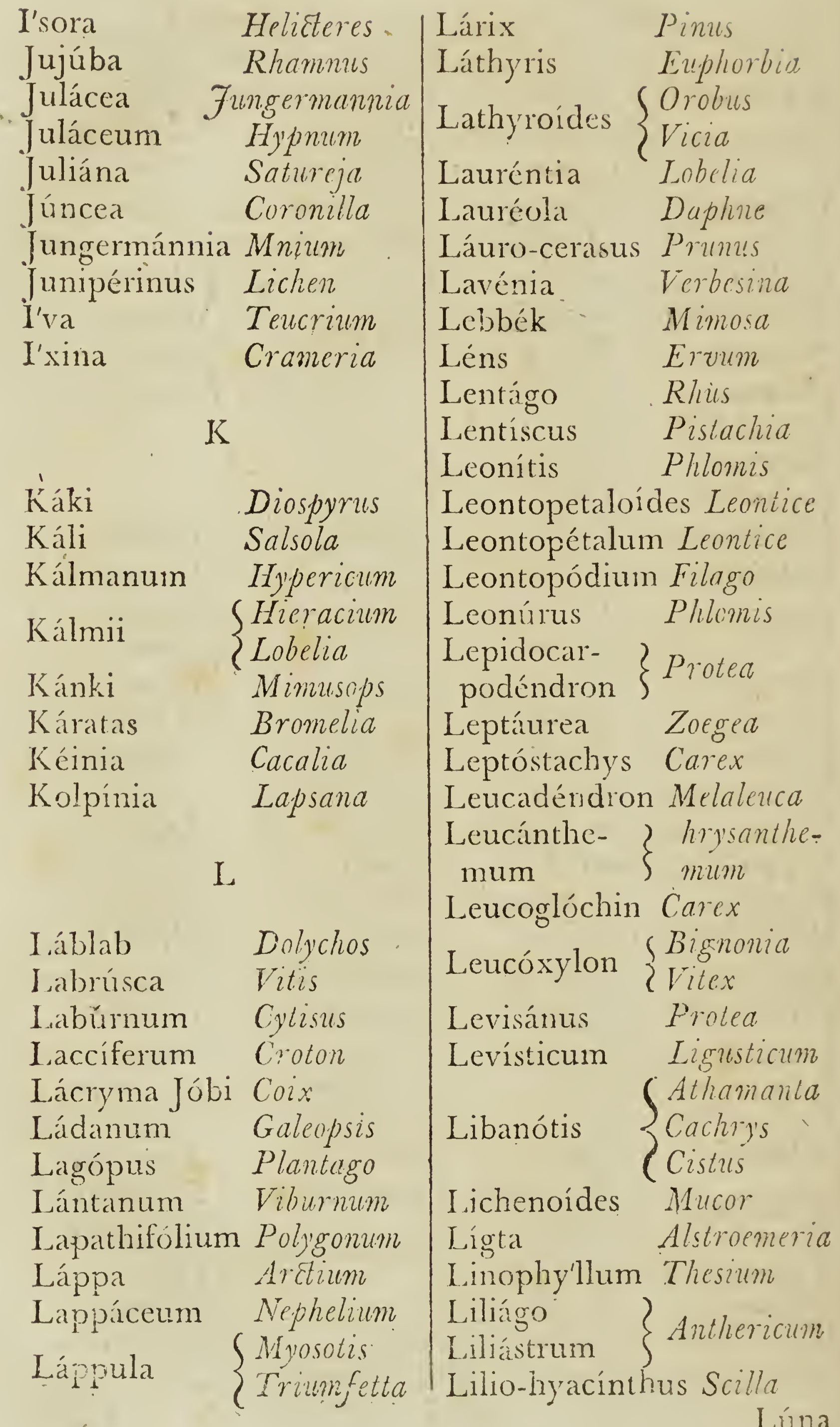


Lina

Limónia

Limónium

Linúria

I.ingúa

Linoides

Linósyris

Línum-stel-

látum

Linza

I.ippii

Lobélia

Locústa

Loesélii

Lonchitis

Loniceroídes

Lopánthus

Lótus

Lucidor

Lúffa

Lunária

Lupináster

Lúpulus

Lutéola

Lychnidea

L.ychnitis

Ly'cia

Lycóctonum

Lycopérsicum Solanum Lygistum
Cynosurus

Campanula Statice

Antirrhinum

Saninculics

SOthonna

Serapias

Chironia

$\left\{\begin{array}{l}\text { Chrysocoma } \\ \text { Lysimachia }\end{array}\right.$

Ulva

Cistus

Scavola

Valeriana

Sisymbrium

Polypodium

Loranthus

Hy) sopus

Shamnus

$\{$ Nymphoea

Diospyros

Antholyza

Momordica

$\{$ Rumex

Osmunda

Trifolium

Humulus

Rescda

Erinus

$\{$ Verbascum

Phlomis

Finiperus

Aconitum

Petesia
M

Mahágoni Swietiana

Maháleb Prunus

Majolána Origanum

Malabáthrica Melastoma

Malacodéndron Stewartia

Malacoides Malope

Malamiris Piper

Malocócca Greuia

Málus Pyrus

Malaviscus Hibiscus

Mancinélla Hippomane

Mandrágora Atropa

Mánghas Cerbera

Mángle Rhizophora

Mangostána Garcinia.

Mamgostánus Amaranthus

Mánihot

Máppa

$\{$ Hibiscus

Fatropha

Ricimus

Marántæ

Acrosticum

Marántina

Globba

Mariána

Mariánus

Maríscus

Clitoria

Carduus

Mármelos

Schoenus

Mártagon

Máru

Cratceva

Lilium

Origanum

Marubiástrum Leonurus

Máruin

Mastichina Thymus

Matrélla Agrostis

Máura Antholiza

Maurocénia Cufsine

Max Plaseolus

Máys
Zea. 
Meádia

Médium

Meleágris

Melánium

Melanóphleus Syderoxylon

Mélilot

Mclittifólia

Mélo

Melocástus

Melóngena

Melópepo

Mercuriális

Meriána

Merianélla

Métel

Metópium

Méum

Mezéreum

Micránthus

Microcus

Micheliánus

Miliáceus

Milleflórum

Millefólium

Mitra

Mitréola

Mnematéia

Mokúsin

Monócera

Moldítrica

Mólle

Mollúgo

Móly

Móly charna Allium

Mómbin

Munniéria $\left\{\begin{array}{l}\text { Dodecatheon } \\ \text { Convolvulus } \\ \text { Campanula }\end{array}\right.$

Frittillaria

Lythrum

Trifolinim

Besleria

Cucumis

Cactus

Solanum

Cucurbita

Tragia

Antholyza

Antholyza

Datura

Khus

E.thusa.

Daphne

Rhamnus

Grewia

Scirpus

Scirpus

Gnaphalium

Achillea

Helvella

Ophiorrhiza

Ehrharta

Phallas

Visnea

Dracocephalum.

Schinus

Galium

Allium

Spondias

Gratiola
Monórchis

Morgsána

Moringa

Mório

Mórsus Rána İudrociaris

Moschatéllina Adoxa

Moschéutos, Mibiscus

Mucéda

Mullúgo

Múngo

Múngos

Murex

Murucúja

Muscári

Muscipula Diona

Mulsénda Gardenia

Mutellina Phellandrium

Myrobálanus Spondias

Myrsinites Euphorlia

Myrtillus Vaccinium

My'siax

Myúrus

My'da

Irugonia.

Manisuris

Curdia

$N$

Nópeca

Napéllus

Nápus

Nardus

Nastáritum

Nátrix

Negíndo

Nelúmbo

Nemolápathum Rumex

Népeta

Nepetélla
Rhatmes

Aconitum

Brafsica

Andropogon

Sysymbrinm

Ononis

$\left\{\begin{array}{l}\text { Vitex } \\ \text { Acer }\end{array}\right.$

Nymphea

Mirlifia

Nepeta 
Nídus N'vis

Nigellástum

Nigrina

Nil

Ninsi

Niruri

Nifsólia

Nifsoliána

Nifsoliánum

Nóbla

Noli tángere

Nóstoc

Núga

Nummulária

Nummulárius

Nux Vómica

Nycteléa

Nymphoídes Menyanthes

\section{$\mathrm{O}$}

O'chus Pisum
O'culus Cati Graphalium
O'culus Christi Imula

Ocymoídes Saponariá

Odontites : Euphrasia

Oenóplia

Oenothérxe

Oleánder

Oleoídes

Ollária

Olusátrum

Rhamnus

Geranizen

Nerium

Rhammus

Oly'mpicum

Onobry'chis

Onites Lecythis

Smyrnium

Hyericum

\{Hedysarum

$\{$ Astragalus

Ophioglofsoídes Clavaria

Opobalsámum Amyzis
Opóponax Pastinaca

O'pulus Viburnum

Opuntia Cadus

Orchioides Hyacinthus

Orellana Bixa

Oreaselinum Anthamantha

Orientále Sisjmbrium

O'rnus Fraxinus

Oróntium Antirrhinum

O'rvala Lamium

Osbéckii Verbascum

Ostrúthium Imperatoria

O'strya Carpinus

Otites . SCucubalus

Polyodiuns

Oxycédrus Funiperus

Oxycóccos Vaccinzum

P

Pádus Prumes

Paliúrus Rhamnus

Pánaces Heracleum

Papáya .. Carica

Papyirus Cuperis

Parálias Euphorbia

Padaliánches Dononicum

Paréira

Paréllus

Cifsampelos

Lichen

Parony'chia Illecebrum

Párra

Parsónsia

Parthénium Matricaria

Paschális

Pafserína

Pafserino

Patiéntia

Pária
Sisymbrium

Lythrum

Lichen.

Stellera

Erica

Rumex

Asculus 


\begin{tabular}{|c|c|c|}
\hline Pecten & Scandix & Hieracizan \\
\hline Pedy'pnois & Hyoseris & Piménta \\
\hline Peletinus & Biserrula & Pimpinelloides Seseli \\
\hline Pémphis & Lythrum & Pinea SEuphorbia \\
\hline Penx'a & Polygala & Pinus \\
\hline Pentacárpos & Hibiscus & Helvella \\
\hline entagónia & Campanula & Bromelia \\
\hline Pentstémon & Chelone & Piperélla \\
\hline Péplis & Euphorbia & Piperita \\
\hline Pél & & Aristolochia \\
\hline Рépo & Cucurbita & Pitajáya \\
\hline Péragua & Carsine & Euphorbia \\
\hline Peréskia & Cactus & Plantagíneum Doronicum \\
\hline Pericly'menum & $n$ Lonicera & Plantáginis Manulea \\
\hline Pérsea & Laurus & Plantágo \\
\hline Pérsica & Amygdalus & Platonoides Acer \\
\hline Persicária & Polygonum & Polygonoídes Calligonum. \\
\hline Personáta & & Pneumonanthe Gentiana \\
\hline Pes Cápra & & srária Aegopodium \\
\hline Pes T'igridis & Ipomoea & $\begin{array}{l}\text { Teucrumm } \\
\text { Pyrus }\end{array}$ \\
\hline Petasites & Tufisilago & Polygónatum Convallaria \\
\hline Petroselínum & Apium & Polytrichoides Mnium \\
\hline Phænopy'rum & Mespilus. & hy'llum Cacalia \\
\hline Phæ'um & Geranium & ónium Liliam. \\
\hline Phegópteris & Polypodium & Hyocharis \\
\hline Phéllos & Quercus & Alizum \\
\hline Phelypa'a & Lathrea & Pcplis \\
\hline Phelgmária & Lycopodium & ulacária Claytonia \\
\hline Phlómidis & Clerodendrum & Portulacástrum Sesuvinm \\
\hline Phu & Valeriana & Atriplex \\
\hline Phyllánthus & Cactus & Carica \\
\hline Physc & & Potatórum \\
\hline Phyléuma & & Prínus \\
\hline Pica & Polypod & Prótium \\
\hline Picea & Pinus & Pséudo-Acácia Robinia \\
\hline Picroídes & Scorzonera & $\begin{array}{l}\text { Pséudo-Acmélla Spilanth } \\
\text { Pséud }\end{array}$ \\
\hline
\end{tabular}


Pséudo-Acórus Iris

Pséudo-Capsicum Solanum

Pséudo-China $\left\{\begin{array}{l}\text { Senecio } \\ \text { Smilax }\end{array}\right.$

Pséudo-Cypérus Carex

Pséudo-Cy'tisus Vella

$\left.\begin{array}{c}\begin{array}{c}\text { Pséudo-Dic- } \\ \text { támnus }\end{array}\end{array}\right\}$ Marmubium

Pséudo-Narcilisus Narcifsus

Pséudo-Pithys Teucrium

Pséudo-Plátanus Acer

Pséudo-Psídium Eugenia

Psycódes

Orchis

Psy'llium

Psyllóphora

Ptármica

Pteránthus Campinorosma

Pterocéphala Scabiosa

Pteróta

Pulégium

Pulicária

Pulsatílla

Pumílea

Pyracántha

Py'rethrum

Q

O

Quámoclit
Quércinus

Plantago

Carcx

Achillea

Fagara

Mentha

Inula

Anemone

Ternora

Mespilus

Anthemis

$\begin{array}{ll}\text { Quámoclit } & \text { Ipomoca } \\ \text { Quércinus } & \text { Agaricus }\end{array}$

R

Radiola

Linum

Rangiferinus

Lichen

Rápa

Brafsica

Raphanistrum Raphanus

Rapuncoloídes Campanula
Rapúnculus Campanula

Rhabárbarum Rhus

Rhagadioloides Hyoseris

Rhagadiolus Lapsana

Rhamonoides Hippophae

Rhapóntica Centaurea

Rhapónticum Rheum

Rhóeas

Ribes

Papaver

Ricinélla

Rheum

Rícino-carpos Croton

Rindéra

Rinocerótis Stoebe

Rítro

Róbur

Roccólla

Echinops

Rosa Sinćnsis Hibiscus

Rósea

Rhodiola

Rótang

Rothmánnia Gardeñia

Royéni

$\{$ Codon

Róyoc

Morinda

Rúta Murária Asplenium

Ruyschiána Dracocephalun

S

Sabdaríffa

Sabína

Salicáría

Satsilla:

Sálsula

Sámbać

Sambúcina

Sanguisórba

Sañtálinus:

Santolína

$\mathrm{E} e$
Hibisciis

Funiperuis

Lythrum

Alstroemeria

Phaca

Nyitanthes

Aquilicia

Poterium

Pterocarpos

Achillea

Satónica 
Satónica

Saponária

Sápota

Sappán

Sarcocólla
Artemisia

SGentiana

S Sapindus

Achras

Casalpina

Penaca

Sarcocómphalus Rhammus

Sarsaparilla Smilax

Sáfsafras

Laurus

Saxifraga

Saxifragus

Scabiósa

Scammónia

Scariola

Scéptrum

Scéptrum

roliánum

Scéptrum Gus-?

taviánum

Scherardiána

Schinoides

Schobéri

Schoenánthus Andropogon

Schoenoides Phleum

Schonóprasum Allium

Scilláris

Sciuroides

Sclaréa

Scolopéndrium

Scólymus

Scopária

Scopólia

Scordioídes

Scordium
Ixia

Hypnum

Salvia

$\left\{\begin{array}{l}\text { Pimpinella } \\ \text { Gypsophyla } \\ \text { Silene }\end{array}\right.$

Cucubalis

Centaurea

Convolvulus

Lactuca

Digitalis

Protea

Malva

Schrebera

Sitrater

\section{Saluia}

Asplenium

\section{Cynara}

$\left\{\begin{array}{l}\text { Chenopodium } \\ \text { Melaleuca }\end{array}\right.$

Hyoscyamus

Siderilis

Teucrium $\left\{\begin{array}{l}\text { Scordótis } \\ \text { Scorodónia }\end{array} \quad \begin{array}{l}\text { Tepela } \\ \text { Scrophum } \\ \text { Scorodón }\end{array}\right.$

Scorodóprasum Allium

Scórpius

Scúrrula

Sebesténa

Secálinus

Secamóne

Securidáca

Sedoides

Selágo

Sénega

Sénegal

Sénna

Seriana

Séridis

Serpentária

Serpy'llum

Serrária

Sesamoídes

Sésban

Sicyoides

Siláus

Síler

Siliqua

Siliquástrum

Simáruba

Siríboa

Sísarum

Sisyrinchium Iris

Smilácina

Sóda

Sója

Solanácea

Solándra

Soldanélla

Sophéra
Loranthu's

Cordia

Bromus

Pepiploca

Coronilla

Penthorum

Lycopodium

Polygala

Mimosa

Cassia

Paullinia

Centaurea

Aristolochia

Thymus

Protea

Reseda

Aschynomene

Cifsus

Peucedanum

Laserpitiun

Ceratonia

Cercis

Quasia

Piper

Sium

Cifsampelos

Salsosa

Dolichos

Atropa

Ij'drocotyle

Convolvulus

Cafsia

Sóphia
Spartium 
Sóphia

Sórghum

Spadicea

Sparganóphora Ethulia

Spéculum

Campanula

Spélta

Triticum

Sphondy'lium Heracleum

Spica

Lavendula

Spicant

Osmunda

Spina Christi Rhamnus

Squamaria

Lathroea

Squarrósa

Stáchydis

Stre'chas

Strehelína

Staphiságria

Stélis

Stoébe

Stoéchas

Stramónium

Stratiótes

Stróbus

Struthiópterís

Strúthium

Styraciflua

A.gilops

Psoralea

Gnaphalium

Xeranthemum

Delphinium

Loranthus

Centaurea

Lavandula

Datura

Pistia

Pinus

Styracifólium Hedysarum

Súber

Succísa

Quercus

Scabiosa

Supranúlium Spartium

Sycomórus Ficus

Symphoricárpus Lonicera

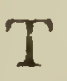

$\begin{array}{ll}\text { Tabácum } & \text { Nicotiana } \\ \text { Tabuláre } & \text { Salyrium } \\ \text { T'xeda } & \text { Pinus } \\ \text { Tágera } & \text { Cassia }\end{array}$

E
Othonna

Tamarisci Fungermannia

Tanarius Ricinus

Típia Craterua

Taráxaci Hieracium

Taráxacum Leontodon.

Tartonráira Daphne

Tátula Datura

Tazétta Narcifsus

Telephioides Andrachne

Teléphium Sedum

Tenagéia Funcus

Téndo Fucus.

Ternatéa Clitoria

Terebinthus Pistachia

Tetragonothéca Polymnia

Tétrahit Galeopsis

Tétralix Erica

Téucrium Veronica

Thalietroides Anemone

Thápsi

Thapsoides Verbascum

Thápsus

Théezans

Verbascum

Rhamnus

Thely'pteris Polypodium

Thevétia Cerbera

Thomæ'a Nardus

Thóra

Ranunculus

Thumbérgía Gardenia

Thy'mbra Satureja

Thymeláea Daphne

Thymifólia Lythrum

Thyoides, Cuprefsus

Tíglium Croton

Tínus Viburnum

Tirucálli Euphorbia

Tithymaloides Euphorbia

Tóra

Cafsia

Tótta 
Tótta

Protea

Tournefórtii Gundelia

Toxicodéndron Rhus

Trachélium Campanula

Tragacántha Astragalus

Tragódes Fagara

Tragoriganum Thymus

Trágus

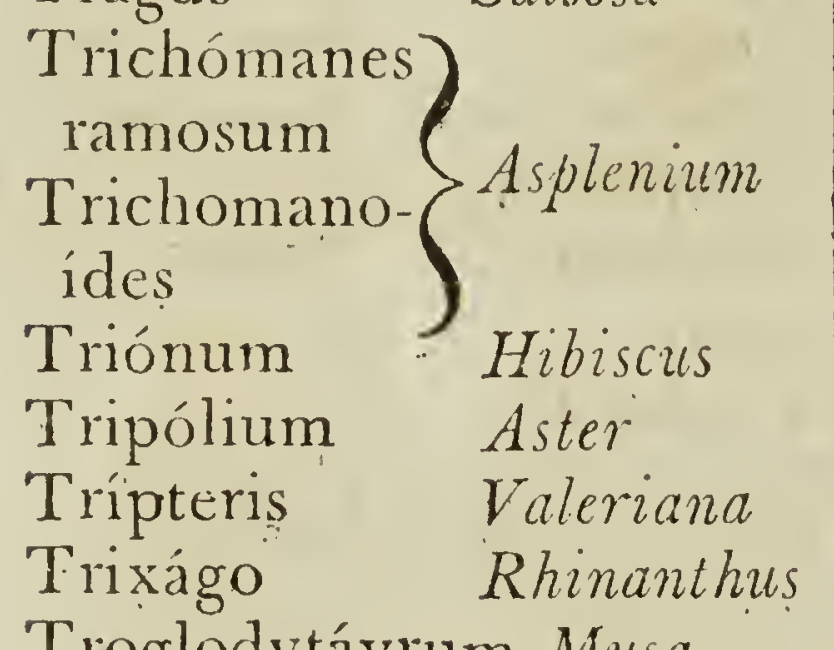

Troglodytáyrum Musa

Tsiámpáca

Túber

Tuberária

Tuberósa

Túna

Túpa

Túrbith

Turpéthum

Turrita

Typhalx'a

Ty'phinum

U

Ulmária
Una Crispa
Unédo
U'niguis Cáti
Uragóga
Urinária

Cistus

Polianthes

Cactus

Lobelia

Seseli

Convolvulus

Arabis

Urena

Rhus

Spircea

Ribes

Arbutus

Mimosa

Myginda.

Phylanthus

$\begin{array}{ll}\text { Urticax } & \text { Begonia } \\ \text { U'snea } & \text { Lichen } \\ \text { Uva Ursi } & \text { Arbutus } \\ \text { Uvária } & \text { Aletris } \\ \text { Uvedália } & \text { Polymnia } \\ \text { Uvifera } & \text { Coccoloba }\end{array}$

V

Vaccária

Saponaria

Valentina $\left\{\begin{array}{l}\text { Coronilla } \\ \text { Anthemis }\end{array}\right.$

Valerándi Samolus

Vanílla

Vascária

Verbenáca

Verbesina

Vérnix

Verútum

Vesicária

Victoriális

Epidendron

Saponaria

Salvia

Cotula

Rhus

Centaurea
Vincetóxicum Asclepias

Vióna Clematis

Virgáurea Solidago

Virginicum Lepidiun

Viscária Lychnis

Visnága Daucus

Vitálba Clematis

Vitaliána Aretia

Vitecélla Clematis

Vitis Idaea Vaccinium

Vulnerária Anthyllis

Vulpína Vitis

Vulvária Chenopodium

Medélia 


\begin{tabular}{|c|c|c|c|}
\hline \multicolumn{2}{|c|}{ W } & \multicolumn{2}{|c|}{ Z } \\
\hline Wedélia & Polyminica & $\begin{array}{l}\text { Zacíntha } \\
\text { Zanónia }\end{array}$ & $\begin{array}{l}\text { Lapsana } \\
\text { Commelina }\end{array}$ \\
\hline & & Zeocrithon & Hordeum \\
\hline & & $\begin{array}{l}\text { Zerúmbet } \\
\text { Zeugites }\end{array}$ & $\begin{array}{l}\text { Amomum } \\
\text { Apluda }\end{array}$ \\
\hline Xiphium & Iris & Zeylánica & Nama \\
\hline Xylósteum & Lonicera & Zibethinus & Durio \\
\hline & & Zingiber & Amomum \\
\hline & & $\begin{array}{l}\text { Zizyphus } \\
\text { Zuzy'gium }\end{array}$ & $\begin{array}{l}\text { Rhamnus } \\
\text { Myrtus }\end{array}$ \\
\hline Yervamóra & Bosea & Zy'gis & Thymus \\
\hline
\end{tabular}

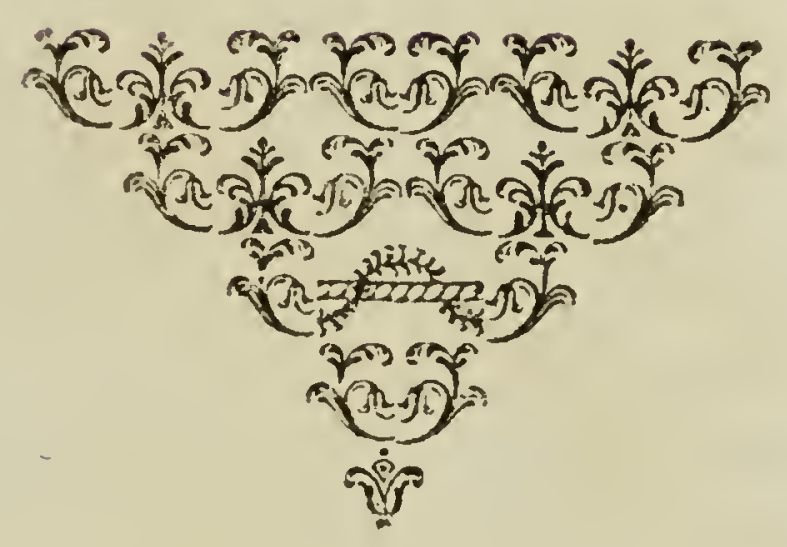





\section{[ 211$]$}

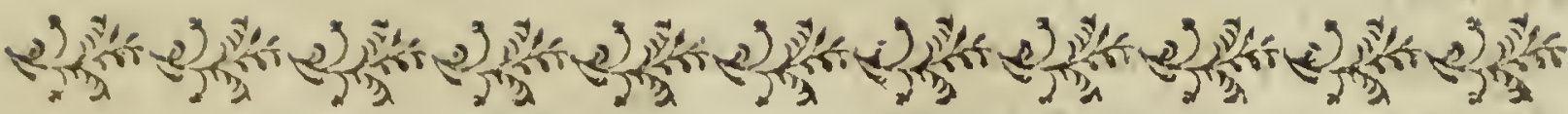

$\begin{array}{lllll}\text { I } & \mathrm{N} & \mathrm{D} & \mathrm{E} & \mathrm{X}\end{array}$

OF T II E

\section{B R I T I S H N A M E S.}

A BELE

1 Abelmosk

Acacia

Acacia, False

Acacia, German

Acacia, Three-thorned; or

Honey locust

Acajou; or Cashew nut

Acanthus, Corinthian; or

Brank ursine

Aconite

Aconite, Winter

Acrostic

Adam's needle

Adder's wort

Adder's or Serpent's tongue

Adrachne

Agaric

Agaric of the oak

Agnus castus ; or

Chaste tree Vitex

Populus alba

Hibiscus abelmoschus

Mimosa

Robinia

Prunus

\} Gleditsia triacanthos

Anacardium occidentale

$\{$ Acanthus spinosus

Aconitum

Helleborus hyematis

Acrostichum

Yucca gloriosa

Polygonum

Ophioglofsum

Arbutus andrachne

Agaricus

Boletus igniarius
Palma Christi

Agrimony

Agrimony, Hemp
$\{$ Ricinus communis

Agrimonia

Eupatorium cannabinum

Agrimony 
Agrimony, Base hernp Ageratum

Agrimony, Naked-headed hemp Verbesina

Agrimony, Water hemp Bidens

Ague tree; or Safsafras

Aikraw

Alaternuis

Alaternus, Base

Alder

Alder, Black

Alecost, or Costmary

Laurus safsafras

Lichen

Rhämmus alaternus

Phylica

Betula alnus

Rhamnus

Alehoof; Gill; or Ground iry Glechoma hederacea Alexanders

Alcali ; or Sal-kali

Alcanet

Allgood; Good Henry; or English mercury

Allheal, Clowns

Allheal, Hercules's

Allseed

Smyrnium olusatrum

Salicornia

Lithospermum

Chenopodium bonus Hen-

S ricus

Stachis palustris

Heracleum panaces

Limum

All-spice; or Jamaica pepper Myrtus pimenta Alligator; or Avocado pear

Almond Amydalus comminis
Almond, Ethiopian or AfricanBrabegum stclluifolim

Laurus persea Almond, Dwarf Aloe, Succotrine Aloe, American Amygalalus nana Aloe perfoliata Aloe, Water; or Water soldierStratiotes aloides Aloes, Wood Althaa frutex Alyfson, Rough-leaved; or Awlwort Amaranthus ; or Flower-gentle Amaranthus Amaranth, Globe Amaranthus tricolor. Amber tree Amellus of Virgil Amomum Plinii Amomum, German Excoccaria agallocha Hibiscus syriacus Subularia aquatica Gomphrenn. Amaranthus tricolor Anthospermum Aster amellus Solanum pseudo-capsicum Sison 
Anemone, Common

Anemone, Wood

Ananas; or Pine apple

Angelica

Angelica, Berry-bearing

Angélica tree

Angelica, Wild; or Goutwort Agopodium padagraria

Anise

Anise tree of China

Anotta; or Arnotta

Apeiba of the Basilians

Apple

Apple, Adam's

Apple, Bitter

Apple, Blad; or W. Indian

gooseberry

Apple, Custard

Apple, Love

Apple, Mad

Apple, Male balsam

Apple, May; or Duck's foot

Apple, Pine; or Ananas

Apple, Purple

Apple, Soap

Apple, Sour

Apple, Star

Apple, Sugar

Apple, Sweet

Apple rThorn

Apple, Water

Apricot

Arbor vita
Ancmone hortensis

Anemone silvestris

Bromelia ananas

Angelica archangelica

Aralia

Aralia
Pimpinella anisum

Illicium anisatum

Bixa orellana

Sloaned

Pyrus mialus

Citrus

Cucumis colocynthis

Cactus pereskia

Annona reticulata

Solanum

Solanum insanum

Momordica

Podophyllum

Bronelia ananas

Annona

Sapindus.

Annona muricata

Chrysophillum

Annona

Annona squamosa

Arbor tristis ; or Sorrowful tree $N y c t a n t h e s$ arbor tristis Arbutus, Trailing

Arcel

Archangel; or Dead nettle

Epigara

Lichen omphalodes

Archangel, Baum-leaved

Archangel, Yellow

Lamium

Melijsa

Galcopsis 
Aria theophrasti; or White beam Cratcous aria Arnotta; or Anotta Bixa orellana Arnuts

Arrowhead

Arrowheaded grafs

Arrow-root, Indian

Avena elatior

Sagittaria

Triglochin

Maranta

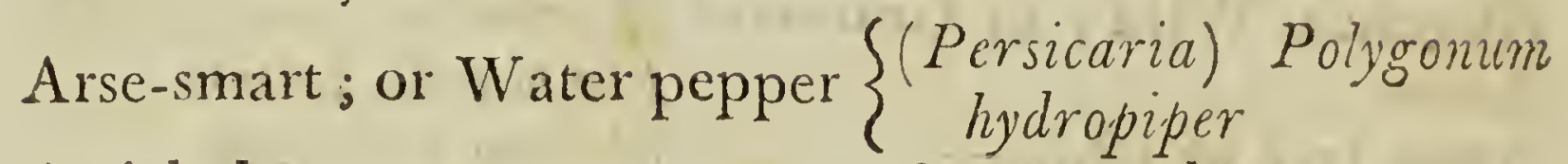

Artichoke

Artichoke, Jerusalem

Arum, African

Arum, Floating

Asarabacca

Ash, Common
Cynara scolymus

Helianthus tuberosus

Calla

Orontium

Asarum

Fraxinus excelsior

Ash, Mountain; or Wicken,

or. Roan tree

\}

Sorbus aucuparia

Ash, Poison; or Varnish tree Rhus vernix

Ash, Sweet or Ground; or

Goutwort

Asparagus, Common

Asparagus, Climing

Asp or Aspen tree

Asphodel

Asphodel, African

Aster ; or Starwort

Avens; or Herb bennet

Avocado; or Alligator pear

Auricula; or Bear's ear

Auricula, Borrage-leaved

Awlwort; or Rough-leaved ?

alyfson

Azarole

Azerita

\}Agopodium podagraria

Asparagius officinális

Medeola

Pcpuilis tremula

Asphodelus

Anthericum

Aster

Geum

Laurus persea

Primula auricula

Verbascum myconi

Subularia aquatica

Cratagus azarolus

Prunus

B

Balm of Gilead

Balm of Gilead, False

Amyiris gileadensis

Dracocephahum canariensis

Balsam 
Balsam

Balsam Copaibi

Balsam of Canada

Balsam of Peru

Balsam of 'Tolu

Balsam tree

Balsam tree
Impatiens

Copaifera officinalis

Pinus balsamia

Myroxylon peruiferum

Toluifera balsamum

Clusia

Pistacia

Balsamine, Female; or Immortal eagle flower

Impatiens balsamina

Balsamine, Yellow; or Noli? me tangere

Bambu cane

\}Impatiens noli me tangere

Banana, a species of Plantain tree

Arundo bambos

Bane-berries; or Herb Christopher Atta a spicata

Banian tree

Bark, True Jesuit's

Bark, False Jesuit's

Ficus

Bark of Elutheria; or CascarillaCroton cascarilla

Bark, Winters

Bardana; or Burdock

Barley, Common spring

Cinchona officinalis

Iva

Barren-wort

Basil

Basil, Field

Basil, American field

Wintera aromatica

Aretium lappa

Hordeum vulgare

Epimedium alpinum

Ocymum

Clinopodium

Monarda

Basil, Syrian field

Basil, Stone

Ziziphora

Thymus acinos

Basil, Wild; or Mother of thyme Thymus serpillum Bachelor's button; Lychnis ; or Campion

Batata; or Spanish potatoe

Baulm, Common

Baulm, Base

Baulm, Moldavian

Baulm, Molucca

Lychnis

Convolvulus batatas

Melifsa officinalis

Melittis melifsophyllum

Dracocephalum moldavica.

Moluccella

Baulm, Indian; or Oswego tea Monarda didyma Baulrn, Turkey

Dracocephalun

$\mathrm{Ff}_{2}$ 
Bay tree, Common; or Laurel of the antients

Bay, Loblolly

Bay, Blue-berried

Laurus nobilis

Gordonia lasianthus

Ligustrum

Bay, Dwarf; or Spurge laurel Daphne laureola

Bay, Sweet-flowering

Bead tree

Magnolia glanica Melia

Beam, White; or Aria theophrasti Cratcegus aria

Bean

Vicia faba

Bean, Kidney, of India; or Soy Dolichos soja

Bean, Kidney or French

Phaseolus

Bean tree, Kidney

Bean tree of "America

Bean tree, Binding

Glycine frutescens

Erythrina

Bean, Caper

Mimosa

Bean, Egyptian; or Water lily Nymphaca nelumbo

Bean, Tretoil

Bean, Trefoil, stinking

Bear-berries; or Uva ursi

Cytisus

Bear-bind

Bear's breech

Bear's ear; or Auricula

Bear's ear sanicle

Anagyris fotida

Arbutus uva ursi

Convolvulus

Acanthus

Primula auricula

Cortusa

Bear's foot; or Setter-wort Helleborus fatidus

Beard, Old man's; or Traveller's joy

Beech

Clematis vitalba

Beet

Bee-flower

Fagus silvatica

Beta

Behen, White; or spatling poppy Cucubalus behen Bell flower

Bell, Canterbury

Bell pepper

Campanula

Campanula meąium

Bella-donna; or Deadly nightshade Atropa belladonna

Belvidere; or Summer cyprefs Chenopodium scrparia

Belly-ach weed

Benjamin tree

Fatropa gofsypifolia

Benjamin tree

Terminaha benzoin

Laurus benzoin

Berberry: 
Berberry, Common; or Piperidge bush

Bermudiana

Bitel

Betony

Bitony: Palil's

Betony, Water

Big barley

Bilbery; or Whortle berry Bindweed
$\int_{S i s y l}$

Sisyrinthium bermudianum

Piper betle

Betonica officinalis

Veronica officinalis

Scrophularia betonicifolia Hordeum hexastichon

Vaccinium myrtillus

Convolvulus

Bindweed, Black; or Black bryony Tamus

Bindweed, Rough

Birch

Sinilax

Birch of Jamaica

Betula alba

Bird cherry; or Cherry laurel Prunus lauro-cerasus

Bird's eye

Bird's foot

Primula farinosa

Ornithopus

Bird's foot trefoil; or Lamb-toes Lotus

Bird's-nest

Bird's-nest

Bird's-nest, Purple

Birth-wort

Bishop's weed, Common

Bistort

Bitter-sweet

Bitter-wort

Black-beryy; or Bramble

Bladder-wort; or Water milfoil Utricularia vulgaris

Blattaria

Blind man's ball

Blinks

Monotropa

Ophrys niaus avis

Orchis abortiva

Aristolochia

Ammi majus

Polygonum bistorta

Solanum dulcamara

Gentiana

Rubus fruticosus

Verbascum blattaria

Lycoperdon bovista

Montia

Blite; or Strawberry spinach

Blite, Amaranth

Blitum capitatum

Amaranthus blitum

Blood-flower; or African tulip Homanthus

Blood-wood; or Logwood Hamatoxylon campechianum Blood-wort

Blue-bottle; or Blue-bonnet; or Cyanus
Rumex sanguineus

Centaibrea cyanus 
Bogbane; or Marsh trefoil Menyanthes trifoliata Bogberry ; or Bogwort Vaccinium

Bonny of Carolina; or Oily grain Sesamum orientale Borecole

Borage

Box

Box, African

(a variety) Brafsica

Box, Low

Boxthorn

Bracken; or Brakes

Borago

Buxus sempervirens.

Myrsine africana

Polygaga

Bramble; or Black-berry

Brank

Brank ursine; or Corinthian acanthus

Brasiletto

Bread, or Plantain tree

Lycium

Pteris

Break-stone; or Saxifrage

Rubur fruticosus

Polygonum

Break-stone parsley; or Par-? sley piert

Briar, Sweet; or Eglantine Rosa eglanteria Briar, Wild or Hep

Brimstone or Sulpher-wort:?

or Hog's fennel

Acanthus spinosus

Cosalpina

Musa sapientum Saxifraga

Aphanes arvensis Bristol, Flower of ; or Nonesuch Lychnis Brocoli (a variety) Brafsica Brooklime; or Water speedwel Veronica beccabunga Broorn, Common becsom Broom, African Spartium scoparium Broom, Dyer's; or Wood waxen Genista tinetoria Broom, Dwarf or Single seededǴrenista
Broum, Rape
Orobanche Broom, Rape, with great pur- $\}$ Lathrcea
ple flowers

Brown-wort

Brown-wort

Bryony, White

Scrophularia

Prunella

Bryony, Black; or Black bindweed Tams communis Buckbean, see Bogbane 
Buck's horn, Plantain Buck's horn, Warted Buckthorn, Common Buckthorn, Sea

Ruck-wheat

Buckee, Hottentot

Bugle

Buglofs

Buglofs, Small wild

Great goose grafs: or

German madwort

Buglof, Viper's

Bullace tree, W. Indian

Billace tree

Burdock; or Bardana

Birdock, Lefser

Bur marigold

Burnet, Garden or Common

Burnet, Greater wild

Burnet saxifrage

Burning thorny plant

Bur reed

Butcher's broom

Butter bur

Butter-cup; Golden-cup ; or

Crow-foot

Butter-wort; or Yorkshire sanicle

Button tree

Button weed

Button wood
Plantago coronopifolia

Cochlearia

Rhamnus:catharticus

Hippopha

Polygonum farnoprousz

Diosma

Ajuga

Anchusa
$\{$ Asperigo procumbens

Echium

Chrysophyllum

Prunus instititia

Aretium lappa

Xanthiun

Bidens

Poterium sanguisorba

Sanguisorba

Pimpinella saxifraga

Euphorbia.

Sparganizm.

Ruscus aculéatus

Tulsilago petasites

\}Ranunculius

$\{$ Pinguicula

Conocarpus erecta

Spermacoce

Cephalanthus

C

Cabbage, Common

Cabbage, Dog's; or Dog's mercury

Cabbage, Sea

Brafsica oleracea

$\{$ Theligonum cynocrambe

Crambe maritima

Cabbage, 
Cakbage, Turnep

Cabbage tree

Cabbage tree; or Foreign colt's-foot

Calabash

Calabash; or Gourd tree

Calamint

Calamint; or Cat-mint, wild

Calamint, Water

Calamus aromaticus; or Sweet flag, or rush

Caltrops

Caltrops, Water

Camboge; or Gamboge (a gum resin) Cambogia gutta

Cammock; or Petty whin; ? or Rest harrow

Campeachy wood; or Log- $\}$ Homatoxylon campechiawood

Camphor tree

Campion, Rose

Campion

Campion, Viscous; or Catchfly Silene muscipula

Canary grafs.

Candle of the Indians

Candy lion's foot

Candy-tuft

Candy-tuft, Perenial

Candy-tuft tree

Cane bambu

Cane or shot, Indian

Cane or Reed

Cane, Sugar

Caper bush

Caraway; or Carui

Canella alba tree

Carduus benedictus

Cardoon

Cardinal flower; or Water gladiole Lobelia cardinalis
Brafsica rapa

Corypha umbraculifera

\}Cacalia kleinia

Cucurbita

Crescentia

Meliss calamintha

Melifsa nepeta

Mentha gentilis

$\{$ Acorus calamus

Tribulus

Trapa natans
Ononis

num

Laurus camphora

Agrostemina coronaria

Lychnis

Phalaris

Rhizophora candel

Catananche

Iberis umbellata

Iberis sempervirens

Iberis semperflorens

Arundo bambos

Canna indica

Arundo

Saccharum.

Capparis

Carum carui

Canella alba

Centaurea benedicta

Cynara cardunculus

Carica 
Carica

Carnation

Carnation, Spanish; or Flow-? cr fence

Carnation tree; or Foreign colt's-foot

Carob tree; or St. John's bread
Carrot, Wild
Carrot, Garden
Carrot, Candy .
Carrot, Deadly; or Scorching fennel

Carui ; or Caraway Carum carui

Cascarilla; or Bark of Eleutheria Croton cascarilla

Cafsada; or CaIsava; or Manihot Fatropa manihot

Calsena; or Y Yapon

Calsia, Poet's

Ilex cajsine

Osyris alba
Ficus carica

Dianthus caryophyllus

Cafsidony; or French Iavender Lavandula stachas

Cafsiobury bush

Catalpa

Cafsine

Bignonia catalpa

Catchfly; or Viscous campion Silene muscipula

Catchfly, Lobels

Catmint; or nep

Catmint, or Calamint, Wild

Cat's foot; or Ground ivy

Cat's foot, Mountain

Cat's tail; or Reed mace

Caterpillars

Cauliflower

Cedar, Red Virginian

Cedar of Jamaica, Base

Cedar, White

Cedar of Bermudas

Cedar of Busaco

Cedar of Libanus

Celandine, Common or greater Chelidonium majus

Celandine, Lefser

Celandine tree
Silene armeria'

Nepeta cataria

Melifsa nepeta

Glechoma hederacea

Gnaphalium

Typha

Scorpiurus

(a variety) Brafísica oleraced

Funiperus virginiane

Theobroma

Cyprefsus

Funiperus bermudiana

Cyprefsus

Pinus cedrus
Ranunculus
G Bocconia frutescens 
Celeriac

Celery

Cereus

Centaury

Centaury, I.efscr

(a variety) Apium
Apium graveolens
Cadus

Centaury, Yellow perfoliate

Ceterach

Chamomile, Common

Chamomile, Dwarf or Sea

\section{Centaurea.}

Gentiana centaurca

Clilora perfoliata Asplenium ceterach Anihemis nobilis

Champignon; or Esculent mushroom

Char; or Sedge Matricaria chamomilia

Charity; Greek valcrian; or $\}$ Jacob's ladder

Charlock; or Ketlock

Charlock, White-flowered, ZRaphanus raphanistrum with jointed pods

Chaste tree; or Agnus castus Vitex

Cheese rennet; or Ladies bed straw

Cherry tree

Cherry, Barbadoes

\} Galium verum

Prunus cerasus

Cherry, Bird; or Cherry, or $\}$ Prumus lauro-cerasus

Cherry, Cornelian

Cornus mascula

Cherry, Dwarf; or Upright honeysuckle

Cherry, Huttentot

Cherry, Winter

Cherry, Alpine

Chervil, Garden

Chervil, Wild

Chestnut

Chestnut, Horse

Chestnut, Indian rose

Chiches; or Chich pea; or Garavances

Chichling-vetch

\} Lonicera corulea

Cafsine maurncenia

Physalis viscosa

Lonicera alpigena

Scandix anthriscus

Charophyllum

Fagus castanea

Esculus hippo-castanum

Mesua ferrea

\} Cicer arietinum Lathyras 


\section{B R I T ISH NA M ES.}

Chickweed

Chickweed, African

Chickweed, Berry-bearing

Chickweed, Great

Chickweed, Mountain

Chickweed, Mouse ear
Alsine

Mollugo verticillata

Cucubalus baccifera

Stellaria

Mothringia muscosa

Cerastium

Chickweed, Sca; or Black saltwort Glaux maritima

Chickweed, Small water

China root

China rose

Chinquapin

Chocolate nut

Christmas rose ; or Black hellebore

Christopher, Herb

Christ's thorn

Chrysanthemum, Base
Montia fontana

Smilax china

Hibiscus rosa-sinensis

Fagus

Theobroma cacao

Chrysanthemum, Hard-seeded Osteospermum

Ciboules; or Welsh onion Allium

Cichory; or Succhory

Cichoreum

Cicuta; or Water hemlock Cicuta virosa

Cicely, Sweet; Myrrhis; or Wild myrrh

Cinnamon tree

Cinnamon, White

Cinnamon, Base

Cinquefoil

Cinquefoil, Marsh

Cinquefoil, Shrub

Cistus, Gum ; or Rock rose Cistus

Acica

Rhammis paliurus

Silphinum

Cistus, Marsh; or Wild rosemary Ledum palustre

Cistus, Lefser marsh; or Base? heath

Cistus, Nettle-leaved

Citron

Citrul; or Water melon

Cives; or Chives

Clary

Andromeda

Titrnera cistoides

Citrus

Cucurbita citrullus

Allium

Salvia sclarea 
Clary, Pyrancan

Horminum

Clivers; Goosegrafs; or Hairiff Galium aperine

Cloud-berry

Clove July flower

Clove tree

Clover, Common

Rubus chamamorus

Dianthus caryophyllus

Caryophyllus aromaticus

Trifolium pratense

Clover, English red; or Cow-grafs Trifolizm alpestre

Clover, White; or Honeysuckle grafs

Cocculus (India berry) Menispermum cocculus
Cockscomb; Rattle; Or Lousewort Pedicularis palustris

Trifolium repens

Cockscomb amaranth

Celosia cristata

Cockscomb; or Yellow rattle Rlinanthus crista-galli

Cockshead; or Saintfoin

Cockle; or Popple

Cocoa nut

Cocoa Plum

Codlings and cream

Coffee, Arabian

Coffee, W. Indian

Colewort

Colewort, Sea

(a variety)

Colewort, Sea

Colocasia

Hedysarum onobrychis

Agrostemma gilhago

Cocos nucifera

Chryscbalanus

Epilobium hirsuture

Criffea arabia

Coffea occidentalis

Coloquintida; or Bitter apple Cucumis colocinthis Colt's-foot

Colt's-foot, Foreign

Tufsilago anandria

Cacalia

Colt's-foot, Foreign ; or Cab-? bage, of carnation tree $\quad$ Cacalia kleinia

Columbine

Columbine, Feathered or Tquitegia.

Aquilegia

Meadow rue

Colutea, Jointed-podded

Comfrey; or Consound* greater Symphytum

Consound,

* Consound, (consolida) a name formerly given to certain vulnerary plants, from their power of conglutinating and consolidating the parts; as symphytum (comirey) was called consulida major, or greater consound, \&c. 
Consound, Middle; or Bugle Ajuga

Consound, Lefser

Prunella

Consound, Least; or Daisy Bellis

Consound, Red

Tormentilla.

Consound. Saracen's; or IVoundwort

\} Solidago

C. nsound, True Saracen's Senecio sarracenicus

Conscund. Marsh

Comarum

Consound, Royal ; or Larkspur Delphininm consolida

Consound, Golden

Cistus

Contrayerva

Dorstenia contrayerva

Contrayerva of Hermandes Pafsiflora

Convolvulus, Scarlet; or Quamoclit Ipomnea quamoclit

Coral tree

Coral-wort; or Tooth-wort

Erythrina

Coriander

Cork tree

Corn, Guinea

Corn, Indian; or Maze

Corn flag.

Corn marigold; or Guills

Corn rose; or Corn poppy

Dentaria

Coriandrum sativum

Quercus suber

Halcus sorghum

Zea mays

Gladiolus

Chrysanthemum segetum

Papaver dubium

Corn sallad; or Lamb's leituce Valeriana locusta

Cornel; or Dog berry

Comelian cherry

Costmary ; or Alccost

Cornus sanquinea

Cornus mascula

Coronopus

Cotton plant

Cotton, Lavender

Tanaceium balsamita

Cochlearia coronopus

Gofsypinm

Cotton tree, Silk

Saniolina

Cotton grafs

Bombax

Cotton weed; or.Cudweed Filago (gnaphalium)

Courbaril; or Locust tree Hymena courbaril

Cow-grafs; or English red clover Trifolium alpestre

Cow-quakes; or Quake grafs Briza

Cow-itch

Cowslip. (a variety) Primula veris officin
Cowslip. American; or Meadia Dodecatheon meadia
Dolichos pruriens

(a variety) Primula veris officinalis

Cowslip 
Cowslip or sage, Jerusalem;
or Lungwort Cowslip, Mountain; or Lungwort Pulmonaria
Cow-weed
Charophigllum

Crab tree; or Apple trec

Crake or Crow berries; cr Empetrum nigrum Black-berried heath

Cranberries; or Bog, Moor, or Whortle berries

Crane's bill

Creeper or Ivy, Virginian; or Five-leaved Canada vine Hedera quinquefolia

Crefs, Garden

Crefs, Virginian

Crefs, Indian; or Nasturtion Tropccolum majus

Crefs, Sciatica

Crefs, Spanish

Crels, Swine's

Lepidium sativum

Lepidium virginicum

Iberis

Vella

Cochleario

Crels, Wall; or Tower mustard Turritis

Crefs, Warted

Crefs, Water

Crefs, Winter

Crofs, Jerusalem

Crois, Knight's

Crofs, Scarlet

Cochlearia

Crofswort

Crocus; or Saffron

Sisymórium nasturtium

Erysimum barbarea

Lychnis

Lychnis

Lychnis

Valantia cruciata

Crow or Crake berries; or ? Black-berried heath

Crow-foot; Golden cup; or Butter cup

Crow-sike

Crown imperial

Cubebs

Crocus

Cuckow flower; or Lady's smock Cardaminie pratensis Cuckow flower; or Ragged Robin Lychnis flos cuculi Cuckow pink

Cucumber

Arum maculatum

Cucumis sativus

Cucumber, 
Cuclimber, Afses, Spurting: or Wild

Cucumber, Egyptian

Cucumber, Serpent

Cucumber, Single-seeded

Cucumber, Small creeping

Cudived; or Cotton weed Guaphalium ( filago)

Cudweed, Base

Cullions

Cullions, Sol lier's

Cumin

Cumin, Base or Wild

Currant

Momordica elaterium

Momordica

Trichosanthes anguine

Sicyos

Melothria pendula.

Micropus supinus

Orchis

Orchis pyramidalis

Cinnimum cyminum

Lagocia cuminoides

Ribes

Currant-leavsd Virginia gel-
der rose

Cufsion, Lady's

Saxifraga hypnoides

Cufsion. Sea; Sea pink; or Thrift Statice

Cyprefs Cyprefsus

Cyprefs, Summer; or BelvedereChenopoidiun scoparia

Cyclamen; or Sow-bread

Cyanus; or Blue-bottle

Cyclamen

Centaurca cyanus

\section{$\mathrm{D}$}

Daffodil

Daffodil, Sea; or Lefser
white squill

Daisy, Common

Daisy, Blue or Globe

Bellis

Daisy, Greater; or Ox eye Chrysanthemum leucanthemum

Daisy, Middle

Doronicum bellidiastrum

Daisy, Michaelmas; or Aster Aster tradescantia

Damson tree

Prunus

Damson tree, W. Indian

Dandelion, Common

Dane wort; Wall wort; or Dwarf elder

Darnel

Chrysophyllum glabrum

Leontodon taraxacum

$\left\{\begin{array}{l}\text { Sambueus ebulus } \\ \text { Lolium }\end{array}\right.$ 


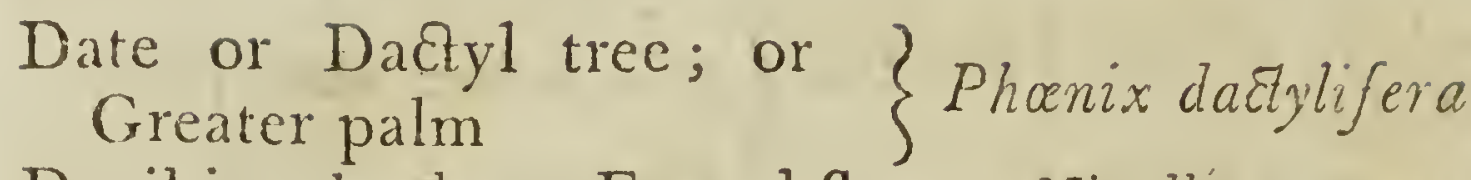
Devil in a bush; or Fennel flower Nigella

Devil's-bit

Devil's-bit, Yellow

Dewberry bush
Scabiosa succisa

Leontodon autumnale

Rubus corsizus

Dyer's weed; or Wild woad Reseda luteola

I yer's weed; or Dyer's broomGenista tinctoria Dill

Dittander; or Pepper-wort Lepidium

Dittany, White; or Fraxinella Ditammus albus

Dittany of Crete

Dittany, Base

Dock

Origanum creticum

Marrubium acetabalosum

Dr. Tinker's weed; or $\mathrm{Fe}-$ )

ver root; or False ipeca- $\{$ Triosteum perfoliatum
cuana

Dodder, European

Dodder of thyme

Dog's-bane

Dog's-bane, Base

Rumex

Dog-berry; Cornel; or Gatter tree Cornus sanguninca

Dog-stones; or Satyrion

Dogwood of Jamaica; or Coral tree

Dogwood tree

Dog's-tooth violet

Dorycnium of Montalier

Cuscuta curnpcea

Cuscuta epithymum

Asclepias

Cynanchum

Double tongue; or Horse tongue Ruscus hyppoglofsum

Dove's foot

Dragons

Dragon's spotted.

Dragon's head

Dragon wort; or Tarragon

Dropwort

Dropwort, Hemlock

Dropwort, Water

Duck meat
Orchis

\}

Erythrina

Piscidia erythrina

Erythronizm dens-canis

C.nvolvulus dorycnium
Geranium

Eracontium

Arum dracontium

Dracocephalum

Artimisia dracunculis

Spirca Filipendula

Oenanthe crocata

Oenanthe

Lemna 
Duck-meat, Starry ; or Star grafs Callitricke Duck's-foot; or May apple Podophyllum Dulse Fucus palmatus

Dwale; or Deadly nightshade Atropa

\section{E}

Ebony

Ebony, False

Ebony of the Alps; or Laburnum Cytisus laburnam

Ebony, Mountain

Edders

Egg plant

Eglantine; or Sweet briar

Elder tree

Elder, .Dwarf; or Danewort

Eilder, Marsh
Eberus

Poinciana

Bauhinia

Arum peregrinum

Rosa eglanteria

Sambucus nigra

Sambucus ebulus

Viburnum opulus
Solanum Melongena Elecampane; or Yellow starwort Inula helenium Elccampane, Base

Elemi tree, Gum

klephant's foot

Helenium

Amyris elemifera

Elephantopus

Filephant's head; or Yellow ratile graf's Rhinanthus

Elichrysum, Base Athiopian Stoebe

Eller ; or Alder

Betula alnus

F.lm, Common

Elm, Witch

Ulmus campestris

Ulmus

Endive

Cichorium endivia

Eringo; or Sea Holly

Eschalot

Evergreen

Eringium maritimum

Allizion cepa

Aizoon

Everlasting, or Eternal flower Gnaphalium

Everlasting, or Eternal flower Xeranthemum

Everlasting; or Globe amaranth Gomphrana

Euonymus

Euonymus, Base Kiggelar
Euonymus, Base; or Staff tree Celastrus

Eye-bright

Euphrasia

Elaterium; or Spurting cucumber Momordica elaterinu

$\mathrm{Hh}$

Farting 
Farting tree; Jamaica wal-? nut; or Sandbox tree

Fat-hen; or Wild orach

Felwort; or Gentian

Felon-wort

Fennel

Fennel, Horse Seseli hippomat
Fennel, Hog's ; or Sulpher-wort Peucedanum

Hura crepitans

Chenopodium vulvaria

Gentiana

Solanum

Anethum foniculum

Seseli hippomarathrum

Fennel, Scorching; or Dead-?

ly carrot

Fennel, Sea; or Samphire
Thapsia

Crithmum maritimum

Fennel flower; or Devil in a bush Nigella

Fennel flower of Crete

Fennel, Giant

Fenugreek, Common

Fern, Common male

Fern, Common female
Garidella nigellastrum Ferula

Trigonella formum-grecum Polypodium filix ma. Polypodium filix femina

Fern, Flowering ; or Osmund royal Osmunda

Fern, Common, or True mules Asplininm

Fern, Mules or Moon; or ?

mule-wort

Fern, Sweet

Feverfew, Common

\}Hcmionitis

Scandix

Feverfew, Base; or Wild? Parthenim hysterophowormwood - $\{$ rus

Fever weed

Fiddle dock

Fiddle wood

Ficoides; or Fig marigold

Ficoides, Diamond; or Ice plant

Fig, Common

Fig, Indian
Eringium fotidum

Rumex pullcher

Citharexylon

Mesembryanthemum

\} Mesembryanthemum cry.

\} stallinum

Ficus carica

SCaktus obuntia: or Cactus fuar indira 
Fig, Infernal ; or Prickly poppy Argemone

Fig, Phamoh's; or True sycamore Ficus sycomorus Fig. Pharaoh's

Fig, Cuchincel ; or Nopal

Figwort

Filbert nut

Mus a

Fingrido, Prickly

Caibus cochenillifer

Scrophularia

Corplus avellana

Pisonia aculeata

Finochia; or Azorean femel

Fir

Fir-mofs, Upright

Flag

Flag, Yellow water

Flag, Corn

Anethum graveolens

Pinus abies

Lycopodium

Iris

Iris pseudacorus

Gladiolus

Flag, Sweet; or Calamus aromaticus

Flammula jovis

Flax, or Line, Common

Flax, Carolina

Flax, Toad

Flea-bane, Greater

Flca-bane, Lefser blue

Flea-bane, Marsh

Klea-bane, Middle

Acorus calamus

Clemat is flamula

Liminn usitatifsimum

Polypremun procumbens

Antimhimun linaria

Conyza

Erigeron acre

Inula pulicaria

Inula dysenterica

Flea-bane, Shrubby African Tarchonanthus

lica-wort

Flix-weed

Flower of Constantinople

Plantago psyllium

Sisymbirion scphica

Iyclinis

Flower-gentle; or Amaranth Amarantius

Fiower of an hour

Ifibiscus trionum

Flower de luce

Flower-fence of Barbadoes;

or Spanish carnation

Flower-fence, Basc

Fluelin; or Speedwell

Fly-bane; or Catch-fly

Four o'clock flower

Foxglove

Iris

Fraxinella; or White dittany Dictammes albus

Adenantinera pavonia

Terónica

Silene muscipula

Mirabilis jalapa

Digitalis purpurea

Pryar's 
Fryar's cowl

Fringe or Snowdrop tree

Fritillary

Fritillary, Cock'scomb; or ?

African swallow wort; or
Fritillaria crafsa

Frog's-bit

Fumatory, Common

Furze; Gorse; or Whin

Fustic trce

Arum arisarum

Chionanthes

Fritillaria

Hydrocharis morsus-rance

Fumaria officinalis

Ulex europacus

Morus tinctoria

\section{G}

Gale; or Sweet gale

Galangale, Larger

Galangale, Lefser

Myrica gale

Cyperus

Kampferia galanga

Gamboge; or Camboge (a gum resin) Cambogia gutta

Garavances, Spanish; or

Chich pea

Garlic

Garlic, Crow or Wild

\} Cicer arietinum

Garlic pear

Gatter tree; or Dogwood

Allium sativum

Allium vineale

Cratceva tapia

Cornus

Gentian; or Fellwort, Yellow Gentiana lutea

Gentian, Base

Gentian, Marsh

Gentianella

Sarothra gentianoides

Swertia perennis

Gerard. Herb; or Goutwort

Germander

Germander, Rock

Gill ; or Ground ivy

Gentiana acaulis

Gilly flower, see July flower
Cinger
Ginseng; or Ninzin
Gladiole, Water
Anomum zingiber
Panax quinquefolia.
Lobelia dortmanna.

Agopodium podagraria

Teucrium chamedry's

Veronica teucrinn

Glechona hederacea

Cladiole, Water; or Flowering rush Butomus umbellatils Cladiole, Water; or Cardinal flower Lobelia cardinalis

Gladwin, Stinking 


\section{Clafs-wort; or Kali}

Salsola

Slats-wort, Jointed; or Kali Salicornia

Clafs-wort, Berry-bearing

Glafs-wort, Shrubby; or

Stone-crop tree

Globe-flower

Coat's-beard

Anabasis

\}Chenopodium

Spharanthus

Tragopogon

Goat's-beard, Garden; or Salsafy Tragopogon porrifolium

Goat's-stoncs, Greater

Salyrium hircinum

Goat's-stones, Lefser

Orchis

Goat's-thorn; or Tragacanth Astragalus tragacantha

Gold of pleasure

Golden-cup; Butter-cup ; or

Crow-foot

Goldylocks

Goldylocks

Good Henry; All-good; or Chenopodium bomus HenEnglish mercury

Gooseberry

Gooseberry, American

Gooseberry, W. Indian; or $\}$

Blad apple

Goose-foot; or Wild orach Chenopodium vulvaria

Goosegrals; Clivers; or Hairiff Galium aperine

Goosegrafs; or Silver-weed Potentilla anserina

Goosegrafs, Great; Small ?

wild buglois; or German
madwort

Goose-tongue Achillea

Go to bed at noon; or Goat's-beard Tragopogon

Gorse; Furze; or Whin

Gourd

Gourd; or Calabash trce

Gourd, Sow of Athiopia; or $\}$

Monkcy's bread

Gourd, Jonas's

Coutwort; or Herb gerrará;
or Wild angelica

Gowan 
Gowan

Grace, Herb of ; or Ruc

Grains of Paradise

Grain, Oily ; or Bonny
Rellis

Ruta graveolens

Amomuni granum Paradisi

Sesamum oriencale

Crain, Scarlet; or Kermes oak Quercus coccifera

Gran, Scarlet; or Cochincel Cnctus cochinillifer

Granadilla

Grape or Vine tree

Pafsifora maliformis Vitis

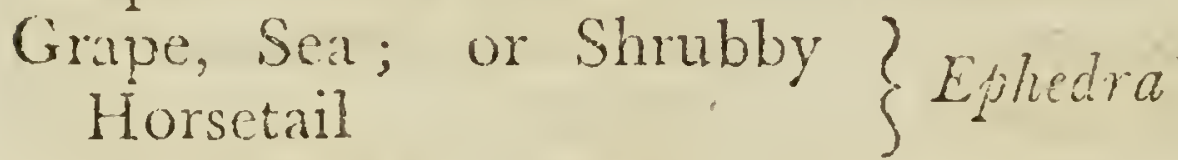

Grape, Sea-side, or Mangrove Coccoloba unifera

Grafs, Arrow-headed

Grafs, Broom

Grafs, Cat's-tail

Triglochin

Bromus

Graf's, Cock's-foot

Phlenm

Grafs, Canary

Dactylis

Phalaris

Grals, Cotton

Eriophorum

Grafs, Darnel; or Rye or $\}$ Lolium tenue

Ray grats; or Bent

Grafs, Dog's, or Couch, or $\{$ Agrostis canina
Quick, or 'Twitch

Grats, Dog's-tail

Grafs, Feather

Grats, Fescue

Grafs, Fex-tail

Grals, Hair

Grafs, Lyme

Grafs, Mat

Grafs, Meadow

Grafs, Millet

Cynosirus

Stipa

Fistuca

Alcpecurus

Airal

Elymus

Nirdus

Poa

Cirats: Oat

Grats Panic

Mition

Aristida

Panicum

Grats of Pamalsus

Parnatsita palusiris

Grats Pepper

Grals. Poley

Grafs, Purple

Grafs, Quake; or Cow-quakes briza

Crafs, Rope or Melic

Piduraria globulifera

Lythrum

Medicago polymortha (arabica)

Melica

Grafs, 


\section{BRITISH NAMES.}

Grals, Rush

Schoemus

Grats, Sedge; or Cyperus grafs Carex

Grats, Soft

Grals, Star

Ayrilops

Grats, Sea

Grals, Scurry

Grats, Timothy

Grals, Toad

Giafs, Vernal

Callitriche

Crals, Wrack

Ruppia maritiona

Cochearia offoinalis

Phloum

Grals, Worm

Gravel-bind

Bufonia temifolize

Anthoxanthum

Zostera

Grecn-iveed

Green sauce; or Sorrel

Grim the collier

Gromwel

Gromwel, Gerinan

Spigelia anthelmiza

Convoluulus

Genista

Rumex acetosa

Hicracium aurantiacum

Lilhospermum

Stallera

Groundsel

Groundsel, Bolonian

Groundsel tree; or Plow-?

Gan's spikcind

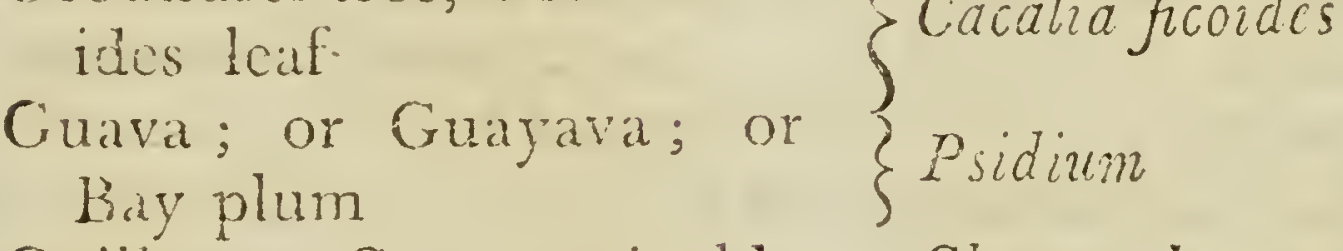

Guills; or Corn marigold Chrysanthemun segetum

Gum succory

Senecio

Erigeron bolonicuse

Baccharis

Chondrilla juncea

H

Hag-berries

Hag-taper; or White mullein Verbascum thapsus

Hairbells

Hyacinthus non scriphus

Hairiff; Clivers; or Goosegrafs Galium aperine

Halimus; or Shrubby sea orach Atriplex halimus

Tiare's-ear Bupleurum tenuifsimum

Hare's-ear, Base shrubby; or
Simpla nobla

Hare's 
Hare's !ettuce; or Sowthistle Sonchus

Hard-head; or Knapweed

Iart's-tongue

Hart-wort, French; or Wild?

Centaurea jacea

srignel

Halli-wort of Crete

Hart-wort, Shrubby

Asplinium scolopendrium

Seseli

Tordilium

Harmel; or Wild Afsyrian rue Peganum harmala

Hawkweed

Hieraceum.

Hawkweed, Base

Hawkweed, Trailing crooked?

seeded; or Yellow eye

Hawkweed, Woolly; or
Downy. Sowthistle Andryala

Haw-thorn; or White thorn Cratagzs oxyacantha

Haw-thorn, Black American Vibumum prunifolium

Hay, Burgundian; or Lucern Medicago sativa

Hay camels; or Sweet rush Andropogon schoenanthus

Hazel nut

Hazel witch, Virginian

Corylus avellana.

Hazel witch; or Hop hornbean Carpinus ostrya

Heart's-ease; or Pansy Violatricolor

Heart-seed

Heath; or Ling

Heath, Base; or Lefser marsh

\section{cistus}

Heath, Black-berried; or

Crow or Crake berries

Heath, Mountain

Heath, Low pine

Heath peas; or Bitter vetch

Heath, Sea

Hedge-hog treroil

Hellebore

Cardiospermum corindusis Erica

$\{$ Andromeda

Empetrum nigrum

Saxifraga nivalis

Coris monspeliensis

Orobus

Frankenia

Helleborus

Hellebore, Black; or Christ-?

mas rose

Hellebore, Fennel-leaved

black; or Perennial adonis $\}$ Adonis

Helleborus niger 
Hellebore, White

Hellebore, Base
Veratrum albuni

Limodorum

Helleborine; or Base hellebore Serapias

$\left.\begin{array}{c}\text { Helmet-flower; Monk's- } \\ \text { hood; or Wolf's-bane }\end{array}\right\}$ Aconitum napeilus Hemlock, Common Conium maculatum Hemlock, Great broad-leav-\{Ligusticum peloponense
cd base

Hemlock, Lefser Eithusá

Hemlock, Water

Cicuta virosa

Hemlock, Waier dropwort

Hemp

Hemp, Base

Oenanthe crocata

Cannabis sativa

Hemp, Base; or Nettle hemp Galeopsis

Hemp agrimony

Hemp agrimony, Base

Hemp agrimony, Nakedheaded Indian

Hemp agrimony, Water

Hemp, Virginian

Henbane; or Hog-bean

Eupatorium cannabinumi Ageratum

$\{$ Verbesina

Bidens

Acnida cannabina

Hyoscyamus niger

Henbane, Yellow; or Tobacco Nicotiana tabacum

Hen-weed, Guinea

Petiveria alliacea

Hepatica; or Noble liverwort Anemone hepatica Hep or Hip tree; or Wild bryar Rosa arverisis

Herb-bane

Herb-bane, Great purple

Orobariche

Herb-bennet; or Avens

Lathrea

Herb-Chritopher; or Bane- $\}$

berries

Herb-Gerard; or Goutwort Agopodium podagraria

Herb of grace; or Rue

Geum

Herb-mastick; or Mastick thime Satureia thymbra

Herb-Paris; True love; or

One-berry

Herb-Paris of Canada; or

Three-leaved nightshade

Herb-Robert

$\{$ Paris quadrifolia

Trillition

Geranium robertianum

Herb. 
Herb-Trinity; or Pansy Violatricolor

Herb-twopence; or Moneywort Lysimachia nummularia Herb-impious; or Cudweed Filago montana Herb, Willow; or French willow Epilobium Herb, Willow; or Purple loosestrife Lythrum

Herb, Willow ; or Loosestrife Lysimachia ephemerum Hercules's club Zanthoxylum clava Herculis Hermodaetyl; or Snake's head iris Iris tuberosa Hiccory nut

Hig-taper: White mullein; or Cows lungwort

Hog-bean; or Hen-bane Hog-weed, American

Hollow-root; or Tuberous moschatel

Holly, Common

Fuglans

Veroascum thapsus

Hyoscyamus

Boerhaavia

Holly, Dahoon; or Paraguay tea Ilex cafsine

Holly, Knee; or Butcher's broom Ruscus aculeatus

Holly, Sea or Eringo

Hollyhock; or Rose mallow Alcea rosea

Honesty; Moonwort; or

Sattin flower

Honewort; or Corn Parsley Sison segetum

Honey flower

$\left.\begin{array}{c}\text { Honey locust; or Three- } \\ \text { thorned acacia }\end{array}\right\}$ Gleditsia triacaulhos

Honeysuckle

\}Lunaria

Honeysuckle, upright, with

red berries; or Dwarf alpine cherry

Honeysuckle, African fly Halleria lucida

Honeysuckle, Americari upright Azalea

Honeysuckle, French

Lonicera.

Honeysuckle grafs; or White ?

clover

Honeysuckle, Jamaica

Honeywort

Hop
Hedysarum

Trifolium repens

Bauhinia divaricata

Cerinthe

Humulus lupulas 
Hop hornbeam; or Witch hazel Carpinus ostrya Horehound, Common

Horehound, Base Marrubium vulgare

Horehound, Base; or IronwortSideritis

Horchound, Black

Horehound, Water

Hornbeam

Hornwort, Common

Horsetail

Ballota nigra

Lycopus

Carpinus beiulus

Ceratophyllum demersum

Horsetail Shrubby; or Sea grape Ephedra

Horsetongue; or Double tongue Ruscus hyppoglofsum

llound's-tongue

Houseleek; or Sengreen

Houseleek, Lefser

Houseleek, Small annual

Houseleck, Water, of Egypt

Humming bird tree

Hyacinth

Hyacinth, African blue umbellated Crinum africanum

Hyacinth, Grape

Hyacinth, Lily

Hyacinth, Peruvian

IIyacinth, Starry

Hyfsop, Common

Ilyfsop, Hedge

Hyfsop, Mountain

Hypericum frutex
Cynnglofsum

Sempervivum

Sedum

Tillcea

Pistia stratiotes

Chelone

Hyacintinus
Hyacinthus muscari

Scilla lilio hyacinthus

Scilla peruviana

Scilla amana.

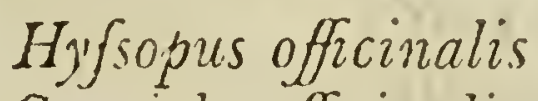

Gratiola officinalis

Thymbra

Spircea hypcricifolia

\section{I}

Iacinth, or Hyacinth

Jack in a box

Iyacinthus

Hernandia sonora

Jack by the hedge; or Sauce alone Erysimun

Jacob's-ladder; Greek vale-

rian; or Charity

Jalap

Jalap

Jasmine

Polemonium

Convolvulus jalapa.

Jasminum

I i 2 
Jasmine, Arabian; or SambacNyctanthes sambac Jasmine, Base

Jasmine, Cape

Cestrum

Jasmine, African ilex-leaved Lantana africana

Jasmine, Fennel-leaved

Jasmine, Persian

Jasmine, Red

Jasmine, Scarlet; or Trum-

pet flower

Jasmine, Yellow Bignonia semper virens

Ice plant; or Diamond fico- Mesembryanthemu cry. ides

Jew's-ear

Immortal flower $\left.\begin{array}{c}\text { Immortal eagle flower; or } \\ \text { Female balsamine }\end{array}\right\}$ Impatiens balsamina

Indian pagod tree

Indian shot; or Cane

Ficus benghalensis

Indian berry, Cocculus

Indigo, Common

Indigo, Base; or Juniper's beard, of America

Job's tear's

Johnsonia

Jonquil

Ipecacuana

I pecacuana, Base

Ipecacuana, False; Fever

root; or Dr. Tinker's weed

Iris, Calcedonian

Peziza auricula

Gomphrana
Ipomoea

Syringa persica

Plumeria rubra

Bignonia

Canna indica

Menispermum coculus

Indigofera anil, है tinctoria

\{Amorpha fruticosa

Coix lacryma

Callicarpa.

Narcifsus jonquilla

Psychotria emetica

Asclepias curajsavica

$\{?$

Triosteum perfoliatum

Iris, Snakes-head; or Hermodactyl Iris tuberosa

Iris, uvaria

Iron-wood

Aletris uvaria

Iron-wort; or Base horehound Sideritis

Judas tree, (see Red bud tree) Cercis siliquastrum Jujube tree

july-flower, Clove

Rhannus jujuba

Dianihus caryophyllus 
$\left.\begin{array}{l}\text { July-flower, Qucen's; Rock- } \\ \text { et; or Dame's violet }\end{array}\right\}$ Hesperis

July-flower, Stock

Cheiranthus

Junctianella, see Gentianella

Junquil see Jonquil

Juniper Funiperus

Juniper's beard; or Silver bush Anthyllis barba jovis

Juniper's beard, American;
or Base indigo

Juniper's distaff

Ivy, Common

Ivy, Bindweed-leaved

Salvia

Hedera helix

Menispermum

hoof; 'Tum-hoof; or Cat's Glechoma hederacea foot Ivy tree; or Dwarf laurel of $\}$ Kalmia
America

Ivy; or Crecper of Virginia Hedera quinquefolia

\section{K}

Kale, or Cabbage, Sea

Kali; or Glafswort

Crambe maritima

Kali, Egyptian

Salsola

Kali, Sal; Alkali; or Jointed glafșivort

Kelp

Kex

Kedlock; or Charlock

Kermes, Oak

Kidney-wort

Mesembryanthemun nodiflorum

King's spear; Aaron's rod; or Asphodel Asphodelus

Kleinia; or Colt's-foot

Salicornia

Knapweed; Matfellon; or Hardhead Centaurca jacca

Knapweed, Thorny

Knawel

Centaurea

Scleranthus

Salicornia

Sium

Sinapis arvensis

Quercus coccifera

Saxifraga

Knee holm; Knee holly; or?

Butcher's broom

$\{$ Ruscus 
Knot-berries

Knot-grars

Knot-grals, Sea

Knot-grafs, German

Knot-grals, Mountain

Knot-grafs, Verticillate
Rubus

Polygonim aviculare

Polygonum maritimum scleranthus

illecebrum

Illecebrum verticillatum

Laburnum; Ebony of the
Alps; or Trefoil tree Cyissus laburnum

Ladder, Jacob's; Greek vale- Polemonium rian; or Charity

Lady's bedstraw; or Cheese rennet Galium verum. Lady's bower,

Clematis

Lady's comb; Venus's comb; or Shepherd's needle $\}$ Scandix pecten

Lady's cushion Saxifraga hyproides Lady's finger; or Kidney vetch Anthyllis vumeraria Lady's mantle, Common Alchemilla vilguris Lady's seal

Lady's shipper Cypripedium calceolus Lady's smock; or Cuckow flower Cardamine pratensis Lady's traces, Troble

Lake-weed

Ophorys spiralis

Polygonum

Lamb's lettuce; or Corn sallad Valeriana locusta

Lamb-toes; or Bird's-foot trefoil Lotus ornithopodioides Larch tree

Lark-heel; or Lark-spur

Pinus larix

Lark-heel, Bee

Delphinium

Laser-wort; or Sermountain Laserpitinm.

Larender; or False spikenard Lavandula spica

Lavender, Sea; or Limonium Statice limonium

Lavender cotton Santolina

Lavender, French; Or Cafsidone Lavandula steechas

Laver Ulva

$\left.\begin{array}{l}\text { Laurel, Cherry; or Bird cher- } \\ \text { ry ; or C'ommon lawel }\end{array}\right\}$ Prumis lauro-cerasus 
Laurcl of the anticnts; or $\}$ Laurvs nobilis
Common bay

Laurel, or Bay of Alexandria Ruscus racemosus

Laurel, Dwarf; or Ivy tree
of America

Laurel, Flax-leaved

Laurel, Sea-side

Daphne gnidium

Laurel, Spurge

Phillanthus

i.aurestinus

Daphne laureola

Lauskraut

Lead-wort

Leather-wood

Leek

Lemon tree

Viburnun tinus

Lemon, Water

Lentils

Delphinium

Plumbago

Dirca palustris

Allizin porrum

Citrus decumanus

Pafsiflora laurifolia

Lentisk; or Mastick

Ervim lens

Lentisk; or mastick, African Schimus

Lentisk; or mastick, Peruvian Schinus molle

Leopard's bane

Leopard's bane, German

Doronicum

Lettuce, Common

Arnica montania

Lettuce, Hare's; or Sowthistle Sonchus

Lettuce, Lamb's; or Corn sallad Valeriana locustos

Lettuce, Wild

Prenanthes muralis

Life, Tree of ; or Arbor vitx Thuja* occidentatis

Life, Tree of, Chinese

Lignum aloes

Thrija orientalis

Cordia

Lignum vitæ; or Pockwood Guaiacum

Lilac

Lily

Syringa vulgaris

Lily, African scarlet

Lily, Asphodel

Lilium

Lily, Atamasco

Amaryllis guttata

Crimun

Lily, Belladonna

Amaryilis atamasco

Amaryllis belladonina 
Lily, St. Bruno's; or Great? savey spiderwort

\}Hemcrocallis

Lily, Conval ; or Lily of the valley Convallaria majalis

Lily, Day

Lily, Guernsey

Lily, Jacobra

Lily, Japan and Ceylon

Lily, Mexican

Lily, Persian

Lily, Martagon

Lily, Crown imperial

Lily, Crown royal

Lily, Daffodil

Lily, Hyacinth

Lily, Superb

Hemerocallis

Amaryllis sarmiensis

Amaryllis formosifsima

Amaryllis orientalis

Amaryllis regina.

Fritillaria persica

Lilium martagon

Fritillaria imperialis

Fritillaria regia

Amaryllis (pancratium)

Scilla lilio-hyacinthus.

Gloriosa superba

Lily, Water; or Egyptian bean Nymphaa nelumbo

$\left.\begin{array}{c}\text { Lily, Lefser yellow water, } \\ \text { with fringed flowers }\end{array}\right\}$ Menyanthes nymphoides

Lily, Thorn

Lily tree

Lime tree

Lime, Brook

Lime, or Linden tree

Catesbcea spinosa

Liriodendron liliifera

Citrus

Veronica beccabunga.

Tilia europea

Limonium ; or Sea lavender

Ling; or Heath

Lion's-foot, Candy

Lion's-leaf

Lion's-tail

Statice limonium

Erica

Catananche

Leontice

Leonurus

Lipplehout; or Cape Phillyrea Cafsine maurocenia Liquorice, True Liquorice, Wild; or Liquo-
rice vetch

Liquorice, Wild ; or Sweet weed Capraria

Liquorice, Wild; or Knob-? bed rooted liquorice vetch Glycine

Live-long; or Common orpine Sedum telephium

Liver-wort

Lichen

Liver-wort, Ash-colored, ground Lichen canimas 


\section{Liver-wort, Marsh Riccia}

Liver-wort. Noble; or Hepatica Anemone hepaticd
I.izard's tail
Saunurus

Lizard or Scorpion's tail Piper

Locker goulands; or Globe
ranunculus Trollius europans

Locust tree; or Courbaril Hymencea caurbarit

Locust tree

Locust tree, Honey; or

Three-thorned acacia

Robinia

Logwood; or Bloodwood Hamatoxylon campechianum London pride; or None so pretty Saxifraga punelata Loosestrife Loosestrife, Podded; or
French willow Epilobium Loosestrife, Purple; or Willow herb Lythrum Loosestrife, Spiked Lythrum salicaria Loosestrife; Willow herb. Spanish Lythrum hyfsopifolia Loosestrife, Yellow Virginian Gaura biennis Lote, or Nettle tree. Celtis Lotus ; supposed of Homer Lotus, Honcy Lovage, Common Love in a mist Love lies a bleeding Diospyros lotis Trifolium Ligusticum levisiticum Pafsiflora fatida Lousewort; Cockscomb; or Rattle Pedicularis palustris Lousewort; or Stavesacie Delphinium staphisagria Lousewort; Cockscomb; or? Rattle, Yellow

Lucern ; Burgundy Hay; or Medick

Lungwort

Lungwort, Cow's; White mullein; or Hig taper

Lungwort, Golden Lupine

Lustwort

Lychnidia; or Lychnis, Base Phlox 


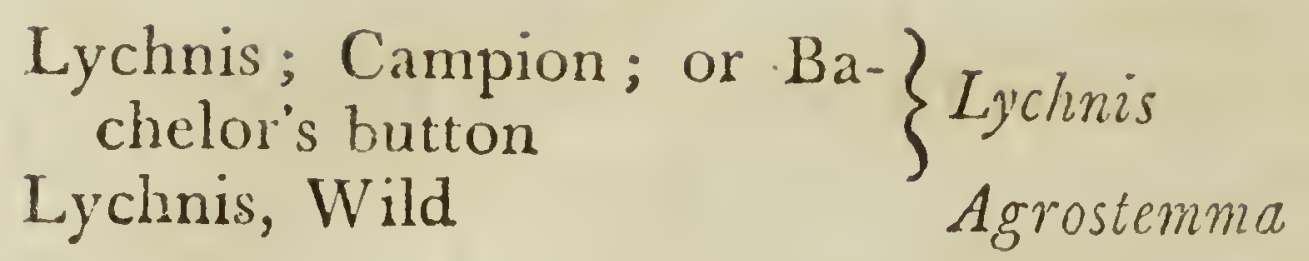

Mace, Reed; cr Cat's-tail

Machingboy

Madder

Madder, Little field

Madder, Petty

Typha

Euphorbia hyberna

Rubia tinctorum

Scherardia

Crucianella

Madder, Crofiswort, or Meadow Galium boriale

Madwort of Galen

Madwort, German; Wild Buglofs; or Great Goose- $\}$ Asperugo grats

Maho tree

Mahogany

Maiden-hail

Marrubium alyfson

Maiden-hair, English black Asplinium adiantumnigrum

Maiden-hair, Tunbridge

Maiden-hair, Golden

Maiden-hair, White

Maize; or Indian corn

Mallow; or Maul

Mallow, Base

Mallow, Jew's

Mallow, Indian

Mallow, Indian

Mallow, Marsh

Mallow, Rose; or Hollyhock Alcea rosea

Hibiscus

Swietenia mahagoni

Adianthum

Trichomanes tunbrigense

Polytrichum

Asplinium

Zea mays

Malvia

Malipe malacoides

Corchorus

Sida

Urena

Althaca officinalis

Mallow, Syrian; or Althaa frutex Hibiscus syriacris

Mallow tree

Mallow, Varied-leaved

Mallow, Portugal

Mallow, Vervain

Mallow, Ycllow

Mammec
Lavatera arborea

Lavatera trimestris

Lavatera lisitanica

Malva

Sida Abutilon

Mammea

Mammec, 
Mammee, Sapota

Achras sapota

Manchincel tree; or Poison tree Hippomane mancinella

Mandrake

Mango tree

Atropa mandragora

Mangosteen

Mangifera

Mangrove tree; or Mangles Rhizophora mangle

Manihot ; or Manioc

Maple, Common

Fatropa manihot

Acer campestris

Maple, Greater; or False plane Acer pseudo-platanus

Maple, Sugar

Maracock

Mare's-tail

Marigold

Marigold, African

Marigold, Corn

Marigold, Fig; or Ficoides

Marigold, Fig, False; or

Groundsel tree with a ficoides leaf

Marigold, French

Marigold, Marsh

Marjoram, Common, or SweetOriganum majorang

Marjoram, Base

Marjoram, Spanish

Marjoram, Wild

Marjoram, pot, Winter sweet; or Origany

Marvel of Peru

Marum, Common

Marum, Pennyroyal-scented

Marum, Syrian, or Cretan

Masterwort
Acer saccharinun

Pafsiflora

Hippuris

Calendula

Tagetes erecta

Chrysanthemum

Mesembryanthemum

SCacalia ficoides

Tagctes patula

Caltha palustris
Origanum

Urtica dodartii

Origanum

\}Origanum hèracleoticum.

Mirabilis dichotoma

Teucrium marum

Melifsa fruticosa

Origanum

Imperatoria ostruthium

Masterwort, Black, or greater Astrantia

Mastic, Herb; or Mastick thyme Thymus masticline.

Mastick, or Lentisk, Indian and African $\{$ Schimus

Mastick, or Lentisk, PeruvianSchimus molle

Masiick, or Lentisk trec

Pistacia lentiscus 
Matfellon; Knapweed; or
Hardhead

Mat-weed, Hooded

Maudlin, Sweet

May, or May bush; or $\}$ Cratcegus oxyacantha

May-weed

Anthemis cotula

Meadia; or American cowslip Dodecatheon meadeo

Meadow-sweet; or Queen of the meadows

Meadow-sweet, Greater

Spircea ulmaria

Mealy tree, Pliant; or Way-? faring tree

Spircéa

Mechoacanna; or White Jalap Convolvulus

Medick

Medick; Lucern; or Burgundy hay

Medick, Sea

Medlar

Medusa's head

Medicago

Melancholy; or Sorrowful tree Nyctanthes arbor tristis

Melilot

Melon

Melon, Water; or Citrul

Mercury, Dog's; or Dog's cabbage

Mercury

Mercury, English: All-good? Chenopodium bonus Henor Good Henry

Mezereon

Meum, or Spignel

Mignonette

Milioil, or Yarrow

Milfoil, or Violet, Wrater

Milfoil, Water

Mifoil, Water, or Hooded;?

or Bladderwort

Milk, or Whice wood
Trifolinm offucinale

Cucumis melo

Cucurbica citrullis

STheligonum cynocrambe Mercurialis

S ricus

Daphne mezererim.

Ririnusa meum

Reseda odorata Achillea millefolium Hottonia palustris Myriophyllum

Utricularia vulgaris Bignonia leucoxy!on 
Milk-rrort

Milk-wort, or Spurge

Mulk-wort, Sea; or Black saltwort Glaux maritima

Millet, or Panic grals

Millet

Millet, Indian

Milt-waste

Mint, Spear

Mint, Pepper

Mint, Cat

Mithridate, or Treacle mustardThlaspi

Misletoe

Moly, with lily flowers

Mombin.

Spondias mombin

Money-wort; or Herb twopence Lysimachia nummularia Money-wort, Base

Monkey-bread; or Sour gourdAdansonia digitata
Monk's-head
Leontodon

Monk's-hood; or Helmet flower Aconitum napellus

Monster

Moon-seed

Mron trefoil

Moon-wort; Sattin flower; or? Hionesty

Moor, or Mols berries; or Cranberries

Mrel

Moringa

Moschatel, Tuberose; or ?

Hollow-root

Mols tree

Mofs, Upright fir

Mols, Water

Mother-wort

Mould

Mouse-ear

Mouse-car, Creeping

Mouse-ear, Golden
Fritillaria

Menispermum

Medicago

Lunaria

Vaccinium oxycoccos

Phallus esculentus

Grilandina moringa

$\{1$ doxa

Lichen

Lycopodiun

Fonínalis

Leonurus cardiaca

Mucor

Heracium dubium

Hieracium piloselia

Hieracim 


\section{$250^{\circ}$ BRITISH N A MES.}

Mouse-car chickweed

Muse-ear scorpion grals

Mouse-tail

M.ch-good

Cerastium

Mysotis scorpioides

Myosurus minimus

Mid-wort; or Least water plantain Limosella aquatica Mug-weed

Mig-wort, Common

Mulberry tree

Valantia Cruciaía

Artemisia vulgaris

Morus

Milberry, or Strawberry blite Blitum capitatum.

Mile, Fairchild's

Dianthus

Mule-wort; or Moon or Mule's fern Hemionitis

Miullein

Mullein, Black

Mullein, Moth

Mullein, White; Hig taper ;

or Cow's lungwort

Mushroom

Mushroom, Esculent; or

Champignon

Mushroom, Cup

Mushroom, Faily

Musk-seed

Mustard

Mastard, Base

Mustard, Pucker; or Base? mithridate

Mustard, Hedge

Mustard, Mithridate of Dioscorides Lepiaim perfoliatum

Mastard, Mithridate; or Treacle Thlaspi

Mustard, Base mithriate; or
Sciatica crefs

Mustard, Tower; or IVall crefs Turritis

Mustard, Base tower

$\left.\begin{array}{l}\text { Myrris; or Wild myrh; or } \\ \text { Swect cicely. }\end{array}\right\}$ Charopinylum syluestre

Myrule

Myrile, Candleberry

Myrtle, litch; or Gale
Verbascum

Verbascum nigrum

Verbascum
$\{$ Agaricus campestris

Peziza

Agaricass

Hibiscus abchmosous

Sinapis

Cleome
\}Biscutella

Erysimum officinale 
$\mathrm{N}$

Naked ladies

Narcitsis polyanthus

Narcilisus; or Daffodil

Narcilsus or Daffodil, Sca

Nard, or Mit-grafs

Nard, Celtic

Naseberry tree

Nasturtion; or Crefs

Nasturtion; or Crefs, Indian

Navel-wort

Navel-wort, Base

Navel-wort, Spring

Navel-wort, Venus's

Navel-wort, Water; or

Marsh pennyroyal

Navew

Nectarine

Nep ; or Catmint

Nettle

Nettle, Dcad; or Archangel

Nettle, Hedge

Nettle, Dead yellow

Nettle, Roman

Nettle, Shrubby hedge

Nettle tree; or Lote

Net-work

Nicker tree

Nightshade

Nightshade, American

Nightshade, Base

(a variety)

Nightshade, Deadly; or Dwale Atropa belladonna

Nightshade, Enchanter's

Nightshade, Malabar

Circea

Basella
Colchicum

Narcifsus tazcita

Narcifsus

Pancratiuni

Nardus

Valeriana celtica

Sloanea

Lepidiun

Cotyledon

Crajsula

Cynoglofsum onphalodes

Cynoglofsum lusitanica

\}Hydrocotyle

Brafsica napus

SAmygdalus persica (tumi-

$\{$ ca glabra).

Nepeta cataria

Urtica

Lamium

Galeopsis

Galcopsis

Urtica pilulifera

Prasium

Celtis

Eriocaulon decangulare

Guilandia

Solanum

Phytolacca

Rivina

Nightshade, Three-leaved; or Canada Herb-Paris

Trillium 
Nip; or Stinking ragwort Nipple-wort; or Wart-wort Lapsana

Nolime tangere; or Yellow Impatiens noli tanbalsamine

None so pretty; or London pride Saxifraga punetata

None such; or Flower of Pristol Lychnis

Nopal; or Cochineel fig

Nose-bleed; or Yarrow

Cactus cochenillifer

Nut tree, Hazel

Nut, Bladder

Nut, Bladder; or Whortle berry, Arrican

Achillea

Nut, Bladder, Laurel-leaved Ilex

Nut, Cashcw ; or Acajou

Nut, Chocolate

Nut, Byzantine

Nut, Cocoa; or Palm

Nut, Earth, or Pig

Nut, Fausel ; or Palm

Nut, Ground of Ancrica.

Nut, Hiccory

Nut, Malabar

Nut, Pea-carth

Nut, Physic, or Purging

Nut, Physic, or Purging

Nut, Pistacia

Nutmeg

Nut, Spanish

Nux-vomica

Corylus avellana

Staphyloca.

Royena

Anacardium occidentale

Theobroma cacao

Corylas colurna

Cocos nucifera

Bunium bulbocrastinum

Areca

Arachis hypogcea

Fuglans

Fusticia adhadota

Lathyrus pisifolia.

Fatropa curcas

Croton

Pistacia

Myristica offucinalis

Iris sisyrinchium

Strychnos mixvomica

0
Oak, Common
Oak, Evergreen
Oak, Dwarf
Oak of Cappadocia
Quercus robur
Quercus Ilex
Teucring
Oak of Jerusalem
Ambrosia maritima
Oak, Poison; or Varnish tree Rhus vernix
Chenopodium botrys.

Oak, 
Oak, Kermes; or Grain oak Oak, Live

Oats

Oats, Sea-side, of Carolina

Oats, Wild bearded

Occulus Christi

Oil tree; Agnus castus; or Palma Christi

Oily puirging grain; or Bonlny of Carolina

Okra

Quercus coccifera

Quercus molucca

Avena

Uniola

Bromus

Inula occulus Christi

Old man's beard; or Travellcr's joy Clematis vitalba

Old man's head

Oleander ; or Rose bay

Olibanum

Oleaster; or Wild olive

Olive

Olive, Spurge

Olive, Wild, of Barbadoes

One-berry; True love; or ? Herb-Paris

One-blade

Onion

Onion, Sea ; or Squill

Opulus ; or: Marsh clder

Orange tree

Orange, Sevile (a variety) Citrus aurantium hispalense

Orange, Mock; or Syringa Philadelphus coronarius

Origany, Pot; or Winter Swcet marjoram

Ornotta (see Anotta)

Orpine ; or Live long

Orpine, Base

Orpine, Lefser

Orpine, True, of Imperatus

Orach, Garden

Orach, Berry-bearing; or Strawberry blite
Dianthis

Neriu, in

Funiperus lycia

Olea

Daphne oleodes

Bontia daphnoides

S Paris quadrifolia

Convallaria

Allium cepa

Scilla maritima

Viburnim

Citrus aurantinum

\}Origanim heracleoticum

Bixa orellana

Sedum telcphizm

Andrachne telephioides

Crajsula

Telephium imperati

Atriplex hortensis

\} Blitum capitatum
Elaagrus 
Orach, Creeping shrubby Atraphaxis inermis

Orach, Wild; or Goosefoot;
or Fat hen

Orach, Shrubby sea; or Halimus Atriplex halimns

Orris, Florence

Osier, Yellow

Iris florentina.

Osier, Brown

Salix vitcllina

Salix amy'gdaina

Osmund. Royal; or Flowering fern Osmunda regalis

Oswego tea

Monarda didyma

Ox-eye

Ox-eye of old authors

Buphthalmum

Ox-eye; or Greater daisy Chrysanthemum leucanthemum

Oxslips; or Cowslips (a variety) Primula veris

Ox-tongue

Oyster-green

Picris
Ulva laduca

\section{$\mathrm{p}$}

Paddock, or Toad stool

Paddock-pipe

Pxony

Agaracus

Equisetum

Pconia

Pagils; or Paigles; or Cowslips Primula veris (officinalis) Painted ladies

Dianthus

Palm, Greater; or Date or? Dactyl tree

Palm, Lefser or Dwarf; cr Palmetto

Palm, Cocoa nut

Palm, Fausel nut

Phonix dadylifera.

Palm, Malabar; called Ampana and Corimpana

Palm, Wild Malabar; called Katou indel

$\{$ Chamarops humilis

Cocos nucifera Areca

\}Borajsus stabelliformis

Elate silvestris

Palm, Mountain, with lar- ? gest leaves; called Codda Corypha umbraculifera

$\left.\begin{array}{l}\text { Panna } \\ \text { Palm, with ringed stems; } \\ \text { called Todda panna }\end{array}\right\}$ Cjcas circinalis called Todda panna

Paln, 
Palm, with bipinnate leaves; called Schunda panna

Palma Christi; Agnus castus; or Oil tree

Pampelmoe; or Shaddock (a variety)

Pansy

Papyrus, Chinese

Papyrus, Egyptian

Papaw tree

Papaw tree of N. America

Paradise, Grains of

Park-leaves

Parsley; or Petroseline

Parsley, Base

Parsley, Com; or Honewort

Parsley, Fools

Parsley, Macedonian

Parsley, Water ; or Smallage

Parsley, Milk, or Cow's

Parsley, Mountain

Parsley, Stone

Parsley, Wild, of America

Parsley piert; or Break stone:

Parsnep or Percepicr

Parsnep, Cow's

Parsnep, Prickly.

Parsnep, Water

Pasque-flower

Pafsion-flower

Patience rhubarb

Pea

Pea, Chich; or Gararances Pea, or Vetch, Chichling

Pea, Earth nut

Pea, Everlasting Pea, Heart
Caryota urens.

Ricinus communis

Citrus aurantium

Viola tricolor

Morus papyrifera

Cyperus papyrus

Carica papaya Annona triloba

Amomum granum paradisi Hypericum androsamum. Apium petroselinum Caucalis

Sison segetum Aithusa Bubon macedonicum Apiun graveolens

Selinum

Athamanta

Bubon

Cardiospermum

Aphanes arvensis

Pastinaca sativa

Heracleum sphondylium

Echinophora

Sium latifolizm.

Anemone prilsatilla

Passiflora

Rumex patientia

Pisum satioum

Cicer arietinum

Lathyrus

Lathyms pisifolio

Lathyrus latifolia

Cardiospermun 
Pea, Heath; or Bitter vetch

Pea, Painted lady

Pea, Pigeon

Pea, Sweet-scented

Pea, Tangier

Pea, Winged

Pea, Wocd

Peach

Peach, Wolf's

Pear tree, Common

Pear, Avocado; or Alligator Pear, Batchelor's

Pear, Garlic

Pear, Prickly

Pearl-wort

Pellitory of the wall

Pellitory, Base

Pellitory, Double

Pellitory of Spain

Pellitory of Spain, False

Pellitory; or Tooth-ach tree

Pennyroyal

Pennyroyal, Virginian

Penny-wort, Marsh;

Water navelwort

Penny-wort, or Navelwort, Wall Cotyledon

Penguin, or Wild ananas

Penstemon

Pepper

Pepper, Black

Pepper, Barbary

Pepper, Bell

Pepper, Bird

Pepper, Bonnet

Pepper, Cayenne

Pepper, Guinea

Pepper, Jamaica; or All-spice Myrtus pimenta

Pepper, Indian
Orobus sylvaticus

Lathyrus

Cytisus cajan

Lathyrus odoratus

Lathyrus tangitamis

Lotus tetragonolobus

Orobus

Amygdalus persica

Solanum lycopersicum

Pyrus communis

Laurus persea

Solanun mammosum

Cratceva

Cactus

Sagina procumbens

Parietaria officinalis

Achillea

Achillea.

Anthemis pyrethrum

Chrysanthemum

Zanthoxylum.

Mentha pulegium

Satureja

or $\{$ Hydrocotyle

Bromelia pinguin

Chelone

Piper

Piper nigrum

Capsicum

Capsicum

Capsicum

Capsicum

Capsicum

Capsicum anmuum
Capsicum

Pepper, 
Pepper, Long

Pepper, Poor man's

Pepper, Wall; or Stone-crap Sedum acre

Piper longum

Lepidium latifoliun

Sedum acre

Pepper, Water; or Arse- (Persicaria) Polygonum smart

Pepper-grafs

Pepper, Pot

Pepper tree

Pepper,wort; or Dittander

Percepier; or Parslcy piert

Pcriwinkle

Persicaria

Pestilent-wort

Petroseline; or Parsley

Pheasant's eye

Pheasant's eye pink hydropiper

Piluraria globulifera

Capsicum

Vitis arborea

Lepidium

Aphanes arvensis

Vinca

Polygonum persicaria

Tufsilago petasites

Apium petroselinum

Adonis

Dianthus

Phyllyrea

Rhanmus alaternus

Phillyrea, False

Phillyrea of the Cape; or

Hottentot cherry

Phu

Pile-wort

Pimento, or All-spice; or

Jamaica pepper

Pimpincl

Cafsine maurocenia

Valeriana

Ranunculus ficaria

Pimpinel, Water; or Brooklime Veronica beccabunga

l'impinel, Round-leaved water Samolus valerandi

Pimpinel of the woods, Yellow Lysinachice nemorm

Pimpillo

Pineaster

Pine tree

Pine, Cembro

Pine, Scotch

Pine, Stone

Pine, Weymouth, or New?

England

Pine, Ground, or Dwarf

Pine, Stinking ground
Cactus

Pinus silvestris

Pinus

Pinus cembra

Pinus

Pinus

Pinus strobus

Teucrium chamaptiths

Camphorosina

Pine, 
Pine, Heath low

Pine apple, or Ananas

Pine apple, Wild
Pine apple, Wild

Pink

Pink, China

Pink, Indian; or Quamoclit

Pink, Indian

Pink, Indian

Pink, Sea ; or Thrift

Pipe tree

Pipe tree, Pudding

Piperidge bush; or Berbery

Piquets, or l'iquettecs

Pistacia nut
Coris monspeliensis

Bromelia ananas

Renealmia exaltata

Pishamin, or Pcrsimon plum Diospyros virginiana Pistacia, Black Virginian ha-? zel-leaved.

Pitch tree

Pitajaya of California

Plane tree

Plane tree, False; or Greater maple

Plant, Buming thomy

Plant, Egg

Plant, Humble sensitive

Plant, Sensitive

Plant, Base sensitive

Plantain, Common broad

Plantain, Hartshorn, or

Bucksl:orn

Hamamelis virginica

Pinus picea

Cactus Pitajaja

Platanus

Acer pseudo-platanus

Euphorbia

Solamm melongena

Mimosa

Mimosa

Eschinomene

Plantago major

¿Plantago coronopifolia

Plantain, Ribbed; or Ribwort Plantago lanceolata

Plantain, Star-headed water Alisma plantago

Plantain, Lcast water; or

Mud-wort

Plantain; or Indian shot

Plantain; or Bread tree

Plim tree

$\{$ Limosella aquatica

Canna indica

Musa paradisiaca Promes 
Plum, Black American; or Cocoa ; or Maiden.

Chry'sobalanus icaco

Plum, Afsyrian; or Sebesten Cordia sebestena

Plum, Bay; or Guava. Psidinm

Plum, Hog; Basilian or Jamaica Spondias

Plum, Indian date

Diospyros lotus

Plum. Pishamin, Persimon,
or Pitchumon Diospyros vir o

Poccoon ; or Puccoon

Sanguinaria canadensis

lockwood; or Lignum vita

Guaicum officinale

Poison tree; or Manchineel

Hipponone manchinella

Poison tree

Rhus toxicodendron

Poison ash or Oak; or Varnish tree Rhus vernix

Poison berry

Poison bush ; or Spurge

Poley, Mountain

Poley grậs

Polyanthus

Polypody

Polyanthus narcifsus

Pomegranate

Pompion

Pond weed

Pond weed, Treble-headed

Poplar

Popple; or Cockle

Poppy

Poppy, Corn ; or Corn rose

Poppy, Horned
Cestrum

Euphorbia

Teucrium polizus

Lythrum

(avariety) Primula veris (elatior)

Polypodium

Narcifsus tazetta.

Punica granatum

Cucurbita pepo

Potomogeton natans

Zannichella palustris

Populus

Agrostemma githago

Papaver

Papaver dubium

Chelidonium corniculatum

Poppy, Prickly; or Fig infernal Argemone

Poppy, Spatling; or White behen Cucubalus behen

Pork weed; or Pork physic Phytolacca

Potatoe

Solanum tuberosum

Potatoe, Indian; or Yam

Potatoe, or Batata, Spanish

Prick wood

Primrose, Common

Dioscorea bulbifera

Convolvulus batatas

Euonymus

Primula veris

Primrose 
Primrose tree; or Night primrose Oenothera

Primrose, Peerlefs

Prince's feather

Privet; or Primp

Privet, Evergreen

Privet, Mock; or Phillyrea

Privy-saugh

Prune; or Plum

Puccoon

Pudding grafs

Pudding pipe tree

Puff-balls

Pulsatilla

Pumpkin (see Pompion)

Purging grain, Oily

Purslain

Purslain, Horse

Purslain, Sea

Purslain, Water

Purslain, Tree sea

Pulegium; or Pennyroyal

Pyracantha

Narcifsus

Amaranthus caudatis

Ligustrum vulgare

Rhamnus

Phillyrea

Ligustrum

Prunus

Sangiinaria canadensis

Mentha

Cafsia fistula

Lycoperdon hovista

Anemone pulsatilla

Cucurbita pepo

Sesamum

Portulaca

Trianthema

Atriplex portulacoides

Peplis portula

Airiplex halimus

Mentha pulegium

Mespilus pyracantho

\section{Q}

Quake grafs; or Cow quakes Briza

Quamoclit; or Indian pink:)

or Sweet William; or Ipomoea quamoclit

Scarlet convolvulus Queen of the meadows; or
Meadow swect

Quick; or White thom Crategus oxyacantha

Quicken; or Wicken; or ? Quick-beam; or Moun-
tain ash

Quince tree

Quill-wort

Pyrus cydonia

Isoetes lacustris 
Radish, Common esculent

Radish, Horse

Radish, or Crefs, Water
Raphanus sativus

Cuchlcarea armoracia

Sisymorium nasturtium

Ragged Robin; or Lychnis cuckow flower

Ragwort, Common stinking; or Nip Senecio jacobea

Ragwort, Sea, or African

Ragworts of old authors

Ragworts of old authors

Rampions, Common esculent Canipdrula rapunculus

Othonna

Senecio

Solidago

Rampions, Horned

Rampions, Cresicd

Rampions with scabious heads; or Hairy sheep's scabious

Ramsons

Ranunculus; or Crow-foot

Ranunculus, Globe; or

Locker gowlands

Ranunculus, Garden

Rape, Cole

Rape, Broom

Raspberry

Raspberry, Flowering

Phyteuma

Lobelia

Jasione montana.

Allizm ursinum

Ranuncullus

\}

Trollius curopaus

Ranunculus asiaticus

Brafsica

Oróbanche

Rubus idaeus

Rubus odoratus

Rattle; Cockscomb; or

Lousewort

Rattle; or Cockscomb, Yel-\} low; or Elephant's head

Rattlesnake root, Senega Polygala senega

Rattlesnake root, Dr. Witt's Prenanthes altifsima

Rattlesnake weed

Red-bud tree; or Canada Ju-

Eryngium aquaticum das tree

Red-worts, Spanish; or ?

Strawberry tree

Recd, Common
Cercis canadensis

$\{$ Arbutus unedo Arundo phragmitis 
Reed, Burr

Reed, Indian flowering

Reed mace

Rennet, Cheese; or Yellow

lady's bedstraw

Rest-harrow; Petty whin ; or

Cammock

Rhamnus, Base; or Sea buckthorn Hyppophae

Reindeer liverwort

Rhapontic

Rhubarb

Rhubarb, True Turkey

Rhubarb, British

Rhubarb, Monk's; or Pa-

tience rhudarb

Ribwort; or Ribbed plantain Plantago lanceolata

Rice

Ricinus, Base

Roan tree; Mountain ash; or Wicken

Robert, Herb

Rocambole

Rock germander.

Rock rose

Rocket

Rocket, Base ; or Weld

Rocket, Corn

Rocket, Marsh

Rocket, Sea

Rocket, Square-podded, of ? Montpelier

Rocket, Water, or Wood

Rocket, Winter

Rocket: Dame's violet; or

Queen's July-flower
Rod, Aaron's ; King's spear ;

or Asphodel

Rod, Bloody
Sparganium

Canna angustifolia Typha
Ononis

Lichen rangiferinus

Rheum rhaponticum Rheum

Rheum palmatum Rumex britanica.

Rumex patientia
Oryza sativa.

Croton

Sorbus ancuparia

Geranium robertianum

Allium scorodoprasum

Veronica teucrium

Cistus

Brafsica eruca

Reseda

Bunias

Sisymbrium .

Bunias orientalis

Bunias cakile

Sisymbrim silvestre

Sisymbriam

Hesperis

Asphodelus

Cormus sanguine

Rod; 
Solidago

Rod tree, Golden; or Yerva mora Bosea yerva-mora.

Rod, Shepherd's; or Teazel Dipsacus fullonum

Roc-buck berries

Rubus sexatilis

Root, Indian arrow

Maranta

Root, China

Root, False china

Smilax china

Root, Fever; or Dr. Tinker's weed Triostcum perfoliatum Root, Hollow; or Tuberous moschatel

Root, Rose

Adoxa moscatellina

Rool, Snake, of Virginia Aristolochia serpentaria

Root, Snake, Black or Wild,

of Virginia

Rout, Sweet; or Liquorice

Rose

Rose, China

Rhodiola rosea

Rose, Christmas; or Black hellebore Helleborus niger

Rose, Corn

Papaver dubium

Rose, Gelder; or Snowball \}riturnum opulus, (flore tree (a variety)

Rose, Virginian Gclder, with?

a currant leaf

Rose, Martinico

Rose, Rock

Rose of Jericho

Rose bay; or Oleander

pleno)

Glycyrriziza glabra

Rosa.

Hibiscus rosa chinensis

Rose bay, Dwarf; or Mountain Rhododendrum

Rose bay willow herb

Rose, Mallow; or Hollyhock

Rose-root

Rosemary

Rosemary ; or Poet's calsia

Spirce opulifolia

Hibiscus muiabilis

Cistus

Anastatica hierochuntica

Nerium olsander

Roscmary, Wild; or Marsh cistus Ledum palustre

Rosemary, Lefser wild

Rose wood

Rue; or Herb of grace

Epilobium

Alcea rosea

Rhodiola rosea

Rosmarimes officinalis

Osyris alba.

Rue, Dog's

Andromeda

Aspalathus

Rita

Scrophularia

$\mathrm{Nm} 2$ 
Rue, Goat's

$\left.\begin{array}{l}\text { Rue, Meadow; or Feathered } \\ \text { columbine }\end{array}\right\} \begin{aligned} & \text { Thalega } \\ & u m\end{aligned}$

Rue, Wall

Rue, Wild Afsyrian

Ruflle, Lady's

Rupture-wort

Rupture-wort, Least

Rush

Rush, Bull

Asplinium ruta muralia

Peganum harmala

Lychnis

Herniaria

Linum

Funcus

Scirpus

Rush, Flowering; or Water gladiole Butomus umbellatus

Rush, Lefser flowering

Rush, Round black-headed,

Marsh, or Bog

Rush, Sweet ; or Calamus aromaticus Acorus calamus

Rye

Rye grafs; or Wild rye

Scheuchzeria palustris

Schoenus

Secale

Hordeum

\section{S}

Sabin; or Savin

Satfion

Saffron, Base; or Safflower

Saffron, Meadow

Saffron, Mountain spring

Sage

Sage, Mild or Wood

Sage, Indian wild

Funiperus sabina

Crocus' sativus

Carthamus tinetorius

Colchicum autumnale

Bulbocodium vermum

Saluia

Teucrium scorodonia

Lantana aculeata

Sage; or Cowslip of Jerusalem Pulmonaria officinalis

Sage, Jerusalem; or Sage tree Phlomis

St. John's bread; or Carob tree Ceratonia siliqua.

St. John's wort, Common Hypericum perforatum

St. Peter's wort; or Base St. John's wort

St. Peter's wort

St. Peter's wort, Shrubby

Saintfoin; or Cock's head

$\{$ Ascyrum

Iigpericum quadrangulare

Lonicera symphoricarpus

Heajsamin unobryctirs

Sallad, Com; or Lamb's lettuce Valeriana locusta. 
Sal-kali; or Jointed glafswort Salicornia
Sallow
Salix fusca

Salsafy; or Garden goat's-beard Tragopogon porrifolinm Salt-wort

Salicornia.

$\left.\begin{array}{l}\text { Salt-wort, Black; or Sea } \\ \text { chickweed; or Milk-wort }\end{array}\right\}$ Glaux maritima

Samphire; or Sea fennel

Samphire, Golden

Sandbox, or Farting tree; or

Jamaica walnut

Sanicle

Sanicle, American

Sanicle, American base

Sanicle, Bear's-ear
Crithmum maritimum

Inula crithmifolia

Sanicle, Yorkshire; or Butterwort Pinguicula

Sandwort

Sappadillo tree

Sapota

Sapota mammee

Saracen's wound-wort; or consound Solidago

Saracen's wound-wort, or? consound, True

Sarsaparilla

Salsatras; or Ague tree

Salsafy (see Salsafy')

Sattin flower; Noonwort; or

Honesty

Satyrion; or Dog-stones

Arenaria

Sloanea

Achras sapota

Achras mammosa

Sanicula

Tiarclla. Heuchera

Mitella

Cortusa

\} Senecio sarracenicus

Smilax sarsaparilla

Laurus safsafras

Tragopogon porrifolium

$\{$ Lunaria

Orchis

Sauce-alone; or Jack by the hedge Erysimum alliaria

Savin; or Sabin

Savin tree, Indian

Funiperus sabina

Saunders, White or Yellow

Saunders, Red

Savory

Savoy cabbage

Saw-wort

Bauthinia aculeata

Saxifrage

Santalum album

Plerocarpus santolinus

Satureja

Brafsica

Scrratula

Saxifraga

Saxifrage, White or Granulated Saxifraga granulato 
Saxifrage, Purnet

Saxifrage, Golden

Saxiliage, Meadow; or

Hog's fennel

Scabious, Common

Pimpinella saxifraga

Chrysospleninum

\}Peucedanum

Scabious, Hairy sheep's; or Rampions with scabious
heads

Scallion

Scabiosa arvensis

Scammony, Syrian, or the true Convolvulus scammonis

Scammony of Montpelier Cymancinun acutum

Sciatica crel's; or Base mithri-? date mustard

Scordium

Iberis

Teucrium scordium

Scorpion grals; or Caterpillars Scorpiurus

Scorpion grafs, Mouse-ear

Scorpion's thorn; or Gorse

Screw tree

Scull or Skull cap

Scurvy grafs; or Spoon-wort

Sea-beard

Sea-fans

Sea-gralis

Sea-reed

Sebesten; or Afsyrian plum

Sedge; or Char

Scdum, Saxifrage

Secd, Heart

Segs

Self-heal

Senna of the shops

Senna, Base.

Senna, Bladder

(Zoophytes*)
Myosotis scorpioides

Ulex europeus

Helidteres

Scutellaria

Cochlearia officinalis

Conferva rupestris

Ruppia maritima

Fuculs

Cordia sebestena

Carex

Saxifraga sedoides

Cardiosperanum

Iris pseud-acorls

Prunclia

Cafsia senna

Cafsice

Colutea arborescens

Senna,

* Zoophyses mcan animal plants; as coralliues, sca-fans, spunge, Eic. which are generally clatied amongst animals. The scasifze plents (whose sensibility is not perfertly accounted for) seem-10 hold the commegtion between real plants and zoophytes, and the zuophytes between sensitiz plents and reat animals. 
Scnna, Jointed-podded blad-? der; or Scorpion senna $\}$ Coronilla emerus

Senna, Wild

Sengreen; or Houseleck

Sensitive plant

Sensitive plant, Base

Septroil; or Tormentil

Sermountain; or Laserwort

Serpent's, or Adder's tongue

Service tree

Service, Maple-leaved, or Wild Cratcegus ierminatis

Sesame; or Oily grain

Setweil, See Zodoary

Setwell, Garden

Setterwort; or Bear's foot Helliborus foxtidus

Shaddock; or Pampelmoe (a variety) Citrus aurantinn

Shallot; see Eschalot (a variety) Allium cepa

Shave grafs

Equisetum

Shepherd's needle; or Venus's comb Scandix pecten Shepherd's purse

Shepherd's rod; or Teazel

Shot, Indian; or Indian cane

Shot, Plantain

Sickle-rivort

Sidesaddle flower

Silk cotton tree

Silk, Virginian

Silver bush; or Jupitcr's beard Anthyllis barba jovis

Silver tree

Thlaspi bursa pastoris

Dipsacus fullonum

Canna indica

Canna

Coronilla

Sarracena

Bombax

Periploca

Protea argentea

Silver weed; or Goose grafs Potentilla anserina

Simpla nobla ; or Base shrub-

by hare's ear

Simpler's joy; or Common vervain Verbena offeinalis

Skirret

Sky flower

Sloe tree

Sloke

Smallage; or Water parsley
Simm sisarum

Cineraria

Prunus spinosa

Ulva

Apium graveolens 
Snail trefoil

Snakè weed

Snake-root, Virginian

Snake-root, Black or Wild of ? America

Snap tree

Snap-dragon

Snap-dragon of America

Sneeze-wort

Sneeze-wort, Austrian

Snowball trce; or Celder rose

Snowberry bush

Snowdrop

Snowdrop, Greater

Snowdrop, or Fringe tree

Soap apple, or berry

Soap-wort

Soft grafs

Soldanel

Soldanel of the shops

Soldier, Water; or Watcr aloe Stratiotes aloides

Soldier's cullions

Soloman's seal

Soloman's seal of America

Sorgo

Sorrel ; or Green sauce

Sorrel, Indian red

Sorrel, Indian white

Sorrel, Wood

Sorrel tree
Medicago

Polygonum viviparum

Aristolochia serpentaria
\} Actaca

Fusticia hyjsopifolia

Antirrhinum

Ruellia

Achillea ptarmica

Xeranthemum anmum

¿Viburnum opulus (flore

$\int$ pleno)

Lonicera

Galanthus nivalis

Leucojum

Chionanthus

Sapindus saponaria

Saponaria

Aigilops

Soldanella alpina

Convoluntus soldanella

Orchis pyramidalis

Convallaria polygona:nm

Uvularia

Holcus sorghum

Rumex aceiosa

Iibiscus

Hibiscus

Oxalis acetocella

Andromeda arborea

Sorrowful, or Melancholy tree Nydanthes arbor tristis

Sour sop

Southern wood

Sow-bread; or Cyclamen

Annona muricata

Artemisia abrotanum

Cyclamen

Soy; or Kidney bean of India Dolichos soja

Sparrow-wort

Sparrow-wort, Traguss's

Pafserina

Stellera pajserina 
Spear-wort

Speerage,

Speedwell

Speedwell, Male; or Fluellin Veronica officinalis

Speedwell, Female

Ramunculus

See $\Lambda$ sparagus

\section{Veronica}

Antirrtinum elatine

Speedwell, Water; or Brooklime Veronica beccabunga

Spice-wood

Spice, All; or Pimento

Spider-wort

Laurus

Myrtus pimenta

Spider-wort, Great savoy; or

St. Bruno's lily.

Spider-wort, Virginian

Anthericum

Spignel, Common; or Meum Ethusa menn

Spignel, Wild; or French hartwort Seleli

Spike grafs, Winged

Spikenard, Indian, or True Nardus indica

Spikenard, Base French Nardus

Spikenard, or Nard, Celtic Valeriana celtica

Spikenard, False ; or Lavander Lavandula spica

$\left.\begin{array}{l}\text { Spikenard, Plowman's; or } \\ \text { Groundsel tree }\end{array}\right\}$ Baccharis

Spikenard, Plowman's; or Fleabane Coniza squarrosa

Spikenard, Wild

Spinach

Asarum

Spinach, Strawberry ; or Blite Blitum capitatum

Spindle tree

Spindle or Staff tree, Climing Celastrus

Spindle tree, Base

Spiræa frutex

Spirza, African

Spleen-wort

Spleenwort, Rough

Spinacia oleracea

Spleenwort, Rough

Spoonwort; or Scurvy grafs

Spunge

Spunk

Spurge ; or Milkwort

(a Zoophyte)

Spurge laurel; or Dwarf bay Daphne laureola

Kiggellaria africana

Spiraca salicifolia

Diosma

Asplenium

Lonchitis hirsuta

Polypodium asplenifolium

Cochlearia officinalis

Agaracus

Euphorbia 
Spurge olive

Spurry

Squash

Squill; or Sea onion

Daphne oleodes

Spergula

Cucurbita melopepo

Scilla maritima

Squill, Lefser white; or Sea daffodil

$\begin{array}{ll}\text { Squinanch } & \text { Asperula } \\ \text { Staff or Spindle tree, Ciiming Celastrus }\end{array}$

Staff, Shepherd's; or Teazel Dipsacus fullonum

Stag's-horn tree

Rhus

Star of Bethlehem

Star of Arabia, and Constan-? tinople

Star of Naples

Ornithogalum pyramidale

Pancratium maritimum

Asperula cynanchica

Ornithogalum arabicum

Star-grafs; or Starry duck meat Callitriche

Star-wort ; or Aster

Star-jelly

Star-wort, Base

Aster

Tremella

Star-wort, Trailing American Tridax procumbens

Star-wort, Yellow; or Elecampane Inula helenizm

Stavesacre; or Louse-wort Delphinium staphisagra

Stitch-wort ; or Star-flower

Stink-horns

Stellaria

Stock Jully-flower

Phallus

Cheiranthus

Stock, Annual, or Ten-weeks Cheiranthus annums

Stock, Dwarf annual

Stock, Virginian

Hesperis

Hesperis

Stonecrop; or Wall pepper Sedum acre

Stonecrop tree; or Shrubby glafs-wort

Stramonium; or 'Thorn apple Datura stramonium

Strawberiy

Strawberry, Barren

Strawberry, Bairen

Fragaria vesca

Fragaria sterilis

Strawberry blite; or Spinach Blitum capitatum

Strawberry trec; or Spanish?

red-worts

Succory; or Cichory

$\{$ Arbutus unedo

Eichorimiz

Succory, 
Succory, Gum

Chondrilla

Succory, Warted; or Zacintha Lapsana zacintha

Sugar cane

Saccarum offcinale

Sulpher-wort; or Hog's fennel Peucedanum

Sultan flower; or Sweet sultan Centaurea moschata.

Sumach

Rhus

Sumach, Myrtle-leaved

Sumach, Tanncr's

Sundew

Coriaria myrtifolia

Coriaria ruscifolia

Sun-flower, Common annual Helianthus annus

Sun-flower, Perennial

Helianthus multiflorus

Sun-flower, Base or Willow leaved Helenium autumnalc

Sun-flower, Dwarf American Rudbeckia.

Sun-flower, Dwarf, of Carolina Polymnia tetragonotheca

Sun-flower, Little

Cistus

Sun-flower, Mariland tickseeded Coreopsis verticillata

Swallow-wort

Swallow-wort, African; or

Cockscomb fritillary

Sweet briar; or Eglantine

Asclepias

\} Stapelia variegata

Sweet John; and Sweet William Dianthus barbatus

Sweet sop

Sweet sultan

Annona squamosa

Swcet weed

Centaurea moschata.

Capraria

Sweet William; and Sweet John Dianthus barbatus

Sweet William, Indian; or

Quamoclit

Swine's crels's

Ipomoca quamoclit

Sycamore, True: or. Pha-
raoh's fig tree Ficus sycamorts

$\left.\begin{array}{l}\text { Sycamore or Plane, Falsc ; } \\ \text { or Greater maple }\end{array}\right\}$ Acer pseudo-platanus

Syringa; or Mock orange Philadelphus coronarius

$\mathrm{T}$

Tacamahaca

Tallow tree

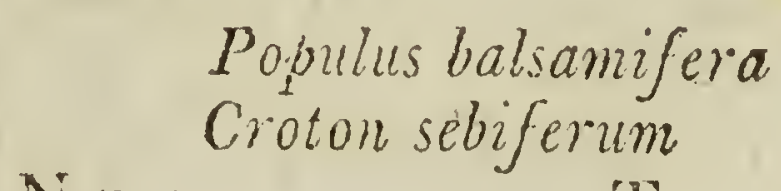

$\mathrm{Nin} 3$

Tamarind 
Tamarind tree

Tamarisk

Tansey, Common

Tansey, Wild
Tamarindus indica

Tamarix

Tanacetum vulgare Potentilla

Tare, or Vetch with black seed Vicia sativa

Tarragon; or Dragon-wort Artemisia dracunculus

Tarton-raire

Tea tree, Bohea

'Tea tree, Green

Daphne tartonraira

Thea bohea.

Tea, New Jersey

Tea, Labrador

Thea viridis

Ceonothus americana

Ledum palustre

Tea, Oswego; or Indian baulm Monarda didyma

Tea, Paraguay; South sea: Yapon; or Dahoon holly $\}$ Ilex cafsine

Teazel, Fuller's; or Shephcrd's rod Dipsacus fullomum

Teazel, Small

Tent-wort

Thistle

Dipsacus pilosus

Aspleniuin

Thistle, Common corn

Carduns

Thistle, Blefsed; or Carduus benedictus

Thistle, Carline

Thistle, Distaff

Thistle, Distaff, Ycllow

Thistle, Fish

Serratula arvensis

Thistle, Fuller's ; or Teazel

Thistle, Globe

Thistle, Golden

Thistle, Hedge-hog

Thistle, Lady's, or Milk

Centaurea benedicta

Carlina

Atractylis

Carthamus lanatus

Cnicus acarna

Dipsacus fullonum

Echinops

Scolymus

Cactus

Carduns mariamus

Thistle, Melancholy

Thistle, Mclon

Carduns helenioides

Cactus

Thistle, Soft, or Gentle

Carduns difsectu.s

Thistle, Solstivial; or Barnaby Centanerea solstitialis

Thistle, Sow; or Hare's lettuce Sonchus

Thistle, Sow; or Wild lettuce Prenanthes

Thisile, Downy sow;

Hocly hawkweed

\}Andryala lanata

Thistle, 


\section{B R I T I S N N M E S.}

Thistle, Torch

Thistle, Wuoly, or Cotton

Thongs

Thorn apple

Thorn, Black

Thorn, Box

Thorn, Christ's

Thorn, Egyptian Mimosa
Thorn, Evergreen; or Pyracantha Mespilus pyracantha 'Thorn, Goat's; or 'Tragacanth Astragalus tragacantha Thorn, Lily.

Thorn, Purging

Thorn, Scorpion's; or Gorse

Thorn, Spanish hedge-hog

Thorn, IW hite; or Hawthorn

Thorny plant, Burning

Thorough wax

Three-leaved grafs

Thrift; or Sea pink

Throat-wort, Greater

Throat-wort, Lefser

'Throat-wort, Blue umbelliferous Trachelium caruleum

Thyme, Common

Thyme, Dodder of

Thyme, Mastick

Thyme, Mother of; or Wild ? thyme; or Basil

Tickseed

Tickseed

Tiger's-foot

Tinker's (Dr.) weed; Fever-? root; or False ipecacuana $\}$ Toad, or Paddock-stool

Toad grals

Tobacco

Tolu tree, Balsam of

"Tomatoes

Tooth-ach, or Pellitory, tree
Cactus

Onopordon

Fucus loreus

Datura stramonium

Prunus spinosa

Lycium

Rhammus spina christi

Mimosa

Catesbara spinosa

Rhamnus catharticus

Ulex europous

Anthyllis erinacea

Cratcegus oxyacantha

Euphorbia

Bupleurum rotundifolium

Trifolium

Statice armeria

Campanula latifolia

Campanula glomerata

Thymus vulgaris

Cuscuta epithymum

Thymus mustichina

\}Thymus serpillum

Coreopsis

Corispermum

Ipomoea pes tigridis

Triosteum perfoliatum

Agaricus

Bufonia tenuifolia

Nicotiana tabacion

Toluifera balsamin

Solanum peruvianum

Zanihorylum 


\section{B R I T I S H N A M ES.}

Tooth-pick; or Visnaga

Tocth-wort; or Coral-wort Dentaria

Tooth-wort; or Lead-wort Plumbago

Tormentil; or Septfoil

Touch me not; er Y tllow

jasmine

Touch me not; or Spurting \{

Tormentilla erecia cucumber

Traveller's joy; or Old man's beard Clematis vitalba

Tree everlasting

Tree mofs

Trefoil

Trefoil, Pean

Trefoil, Stinking bean

Gnaphalizm arboreun

Lichen

Trifolium

Cytisus

Trefoil, Hedge-hog Medicago polymorpha(intertexta)

Trefoil, Bird's-foot

Lotus

Trefoil, Marsh; or Bog-bean

Trefoil, Mioon

Trefoil, Shrub

Menyanthes trifoliata

Medicago

Ptelia trifoliata

Trefoil of Montpelier, Shrub Lotus dorycnizun

Trefoil, Snail

Trefoil, Thorny, of Candia Fagonia cretica

Trefoil tree; or Laburnum Cyisus laburmum

Trefoil, Base tree

Trichomanes

True love; or Herb Paris

True love; or Herb Paris of

America

Trufles Lycoperdon tuber

Trumpet flower: or Scarlet jasmine

Thbe rose

Tulip

Cytisus

Asplenimm trichonanes

Paris quadrifolia

\}

Tulip, African; or Blood-flower Ifcemanthus

Tulip, Checquered

Tulip tree

Tulip tree, Laurel-leaved

Tum-hoof; or Ground ivy
Fritiliaria meleagris

Liriodendum tulipifera. Magnoliat

Glechoma hederacea 
Tupelo tree

Niysa aquatica

Turbith, Indian, or of the shops Convolvulus turbethun

Turbith, Garganic

Turkey feather

Turk's cap; or Martagon

Turk's head

'Turk's turban

Tumep

Tumep, French (a variety)

Turmeric

Turnsol; or wart-wort

Turpentine tree

Thapsia garganica:

Ulua favonia

Tutsan; or park-leaves

Twopence, Herb; or Moneywort

Twa, or Twy blade

Lilium martagon

\section{Cactus}

Raninculus

Brafsica rapa

Brafsica rapa

Curcuma longa

Iteliotropium

Pistacia terebinthus

Hypericum:androsanum

I.ysimachia nummularia Ophrys

\section{V}

Valerian, Garden

Valerian, Greek; Jacob's lad-? Polchionin phu der; or Charity $\}$ Polcrionium

Vanilla; or Venelloe Epidendrum vanilla

Varnish tree; or Poison ash, or Oak

Venus's comb; or Shepherd's
needle

Venus's looking glars

Venus's navel-wort

Vernal grafs

Vervain

Vervain, Common; or Simpler's joy

Vervain mallow

Vetch; or Tare

Vetch, $\mathrm{Ax}$, or Hatchet

Vetch, Bitter

Vetch, Bitter; or Heath peas

Rhus vernix

$\{$ Scandix pecten

Camipainula speculum

Cjnoglofsum lusitanicusn. Anthoxanthuini

Verbena

\} Verbena officinalis

Malva

Vicia

Coronilla securidaca Ervum ervilia 
Vetch, Jointed podded bitter Ervum lens

Vetch, Chichling

Vetch, Crimson grafs

Lathyrus

Vetch, Clusius's foreign hatchet Biserrula pelecimus

Vetch, Horse-shoe

$\left.\begin{array}{l}\text { Vetch, Kidney; or Lady's } \\ \text { finger }\end{array}\right\}$ Anthyllis

Vetch, Liquorice Astragalus glycyphyllus

Vetch, Knobbed-rooted liquorice Glycine

Vetch, Milk

Vetch, Base milk

Vetch, Venetian

Vetch, Medic

Vetchling

Vetchling, Yellow

Viburnum

Viburnum, American

Vine tree

Vine, Black; or Black bryony Tamus

Vine, Climing five-leaved, of ?

Canada; or Virginian ivy, Hedera quinquefolie or Creeper

Vine, Spanish arbour

Vine, White; or White bryony Bryonia alla

Violet, Common

Violet, Bulbous; or Snowdrop Galanthus nivalis

Violet, Calathian

Violet, Dames; Rentiana

$\left.\begin{array}{l}\text { Violet, Dames; Rocket; or } \\ \text { Queen's July-flower }\end{array}\right\}$ Hesperis

Violet, Dog's-tooth

Violet, or Milfoil, Water

Viper's grafs

Virgin's bower, Blue

Viorna

Visnaga ; or Tooth-pick

Umbrella tree

Uva ursi ; or Bear berrics

Urine-wort
Astragalus

Phaca

Orobus

Hedysarum

Astragalus onobrychis

Lathyrus aphaca

Viburnum:

Lantana

Vitis

Ipomoca tuberosa

Viola odorata

Erythronium dens conis Hottonia palustris

Scorzonera

Clematis viticella

Clemaits viorna

Daucus visnaga

Magnolia tripetala

Arbutus uva ursi

Saxifraga hirculus

Wagebroom 
W

Wagebroom

Wake Robin

IVall-flower

Walnut tree

Walnut, Jamaica; Sandbox

tree; or Farting tree

Walnut, Virginian; or Hiccory Fuglans

Wall-wort; Dane-wort; or

Dwarf elder

Wanhom

Ware, Sea

Wart-wort

Wart-wort ; or Turnsol

Wart-woft ; or Nipple-wort

Water-leaf

Water-wort

Wayfaring; or Pliant mealy tree Viburnum lantana

Weed, Sweet; or Wild liquorice Capraria

Weld; or Would; or Base rocket Reseda

\section{Wheat}

Wheat, Buck

Wheat, Cow

Wheat, French
Protea argentea

Arum maculatum

Cheiranthus cheiri

Friglans regia

Sambucis ebulus

Kampferia

Fucus vesiculosus

Euphorbia tithymaloides

Heliotropizm

Lapsana

Hydrophyllum

Elatine hydropiper
Triticum

Polygonum fagopyrum

Melampyrum

Polygonum .

Wheat, Turkey; or Indian maize Zea

Whin; Furze ; or Gorse

Whin, Petty; Cammock; or

Rest-harrow

Ulex europcous.

\} Ononis antiquorum

Whin, Petty; or Small broom Genista anglica

Whistles, Sea

White beam; White leaf

tree; or Aria theophrasti Cratcegus aria

White, or Milk wood

Whitlow grafs

Whitlow grafs, Common

Fucus nodosus

Whitlow grafs, Rue-leaved

Bignonia leucoxylon

Draba

Draba verna

Saxifraga tridactylites

$\mathrm{O}$ - Whortle. 
Whortle-berry; Red-worts ; or Bilberry

Whortle-berry, or Bladder nut, African

Whorts, Black

Vaccinium myrtillus

\} Royena

Vaccinium

Whortle-berry, with flowers single Vaccinium vitis idaea

Whorts, Bog or Moor; or Cranberry Vaccinium oxycoccos

Whorts, Spanish red; or

Strawberry tree

Wicken; Quickbeam; Moun-

tain ash; or Roan tree

Widow-wail

Willow

Arbutis unedo

Sorbus aucuparia

Cneorum tricoccon

Salix

Willow, French; or Willow herb Epilobium

Willow, Spiked, of Theophrastus Spirca

Willow, or gale, Sweet

Willow herb; or Purple loosestrife Lythrum

Willow herb; or Yellow loosestrife Lysimachia vutgare

Willow herb, Rosebay

Willow, Weeping

Wind-flower; or Anemone Anemone

Wind-seed

Winter-berry

Winter-bloom

Epilobium angustifolium

Sálix babylonica

Arctotis

Prinos verticillatus

Winter-green

Azalea

Pyrola

Winter-green, Ivy flowering Kalmia

Winter-grcen, with chick-

weed flowers

Woad, Common

\} Trientalis europia

Woad, Wild; Dyer's or Yellow weed

Wolf's bane; or Aconite Aconitum

Wolf's bane; or Winter aconite Hellebonus hyemalis

Wolf's claw

Woodbind; or Honeysuckle Lonicera

Woodbind, Spanish; or Ar-

bour vine

Lycopodium

I Ipomoea tubcrosa 
Wood of life; or Lignum vita Guaiacum

Woodroof Asperula

Wood-waxen; or Dyer's broom Genista tinetoria

Worm-grafs

Spigelia anthelmia

Worm-seed

Wormwood

Chenopodium anthelminticum

Wormwood, Sea Artemisia absinthium

Wormwood, Wild; or' Base $\}$ Parthenium hysteropho. feverfew

Artemisia maritima

Wortle, Petroseline; or Parsley Apium petroselinum

Woundwort of Achilles

Woundwort, Clown's

Achillea

Woundwort, or consound, Saracen's Solidago

Woundwort, True Saracen's Senecio sarracenicus

Wrack

Wrack, Grafs

Fucus

Zostere

\section{Y}

Yam, or Yaum; or Indian potatoe Dioscorea bulbifere Yapon; Cafsina; or South sea tea Ilex cafsine Yarrow

Yellow-root (see Milfoil) Achillea

Yellow-weed; or Wild woad Reseda luteola Yerva-mora; or Golden rod tree Bosea yerva mora Yew tree, Common

Taxus baccata

\section{$\mathbf{Z}$}

Zacintha; or Warted succory Lapsana zacintha

Zedoary, Round

Zedoary, Long ; or Galangal Kampferia galanga

Zerumbet; or Wild ginger Amomum zerumbet 


\section{A T A B L E of Vegetable D R UGS not in the INDEXES.}

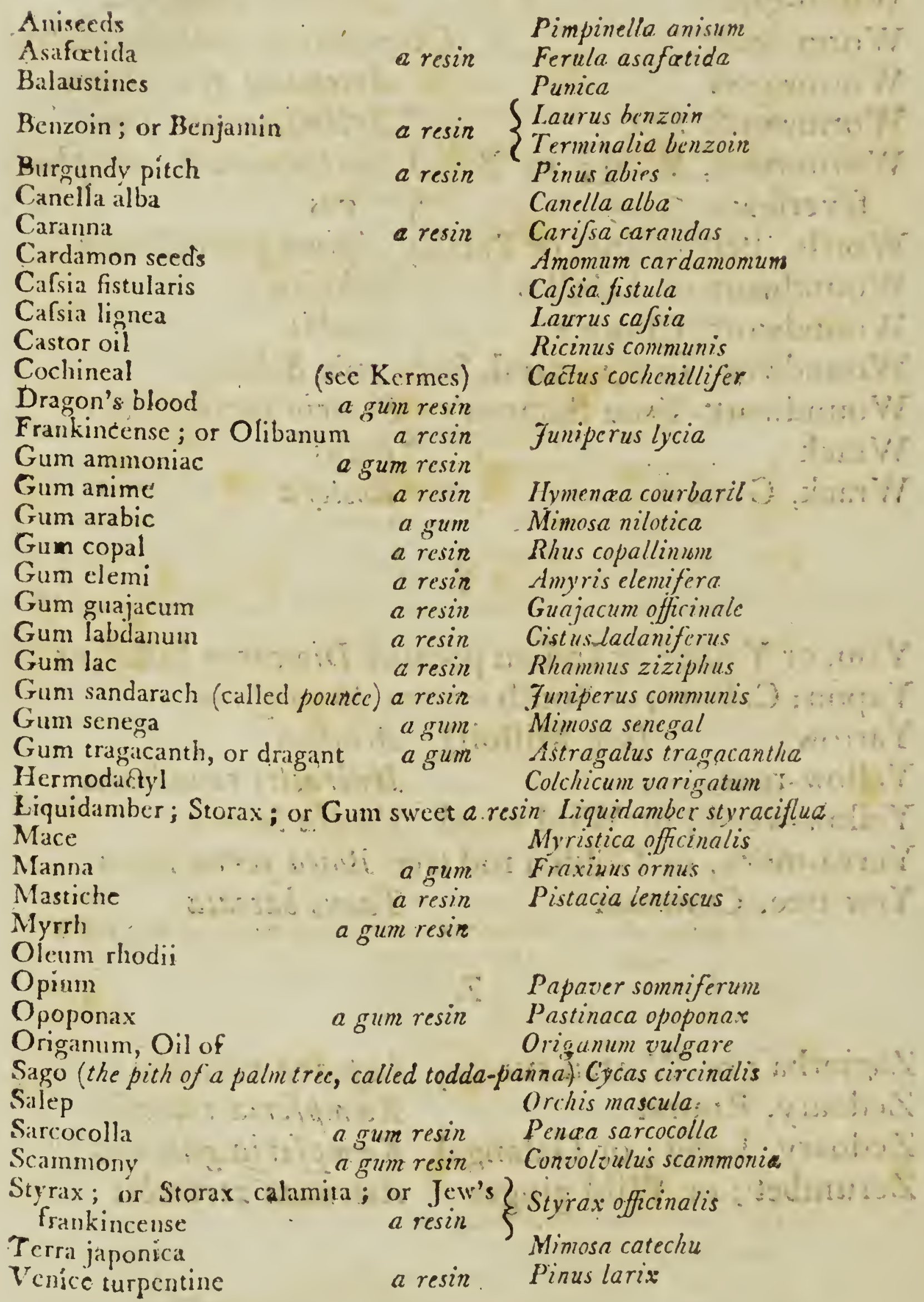




\section{E $R \quad R \quad A \quad T A$.}

Page 7, line 24, for tropalum read troparolum

8 , lines 2.4 and 30 , for anthera read anthera

line $\mathbf{2 8}$, for filam read filume

35 , line 15 , dele at spring 18, dele (which flowers)

37 , line 19, for bulbous read bulbus

42, line 9, for ecnhiridion read enchiridion

4.5 , Calceolaria, under species read 3

46, Veronica, under spccies read to

49, for Wackendorfia read Wachendorfie for Anthistria read Anthistiria

5.5. Sirium, under species read 1

58 , Vinca, under growth read $s \in \mathcal{E} / 2$

62, notes line 4 , for dies read die

66, Apium, under species read 2 for Scambucus read Sambucus notes line 4 , after Linnxus, read, being only a variety from Smallage

69, Frankenia, under species read 3

79 , Toluifera, read $t, \mathbf{1}, S$. America.

80, for Henatoxylon read Hamatoxylon

81 , Codon, under growth read s

83 , Sedum, under species read 19

84 , notes line 5 , dele (mangrove or mangles) and insert (candel)

85 , Euphorbia, under growth read $h \mathbb{S} s$

89, Rubus, under growth and species read $s \mathcal{E} h, 19$

90, for Ternstromia read Ternstroemia

93, Fothergilla, under species read 2 Nigella, under species read 5

94, Ranunculus, under species read 42

98, Bartsia, under species read 5

103, Cheiranthus, under species read 19

Brafsica, under species read 12

10., Myagrum, under species read 9

106, before Order OEtandria, read Order Heptandria, (sevest males) African geraniums

108, Lavatera, under species read 9

125, Imula, under species read 25

127, for Sylphium read Silphium

131, Serapias, under species read 9

132 , Helicteres, under species read 6

${ }_{1} 36$, Betula, under species read 7

137, for Paterium read Poterium

138 , notes line 7 , for racinus read ricinus

141 , notes line 9 , for or read and

150 , Isoetes, under species read 2

278, after Lycopsis, read Small wild bugloss

219, between lizes 8 and 9, read Buglofs, Small wild-o.. Lycopsis arvensis. 


$$
\text { is: }
$$

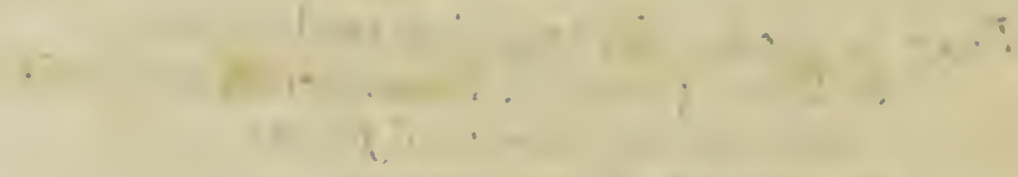

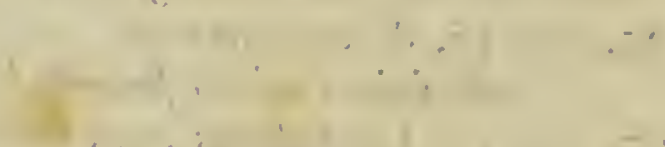$$
\begin{array}{llll}
1 & \cdots & \cdots & +
\end{array}
$$

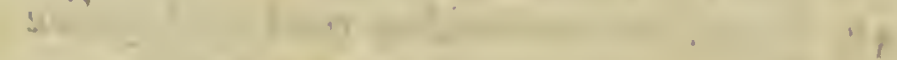

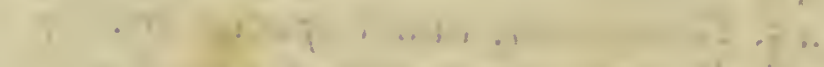

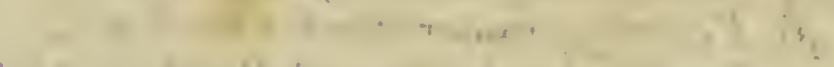

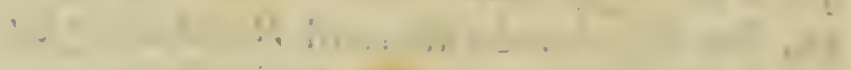

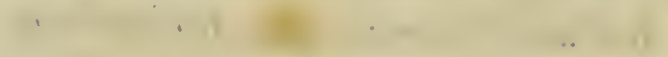

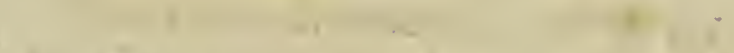

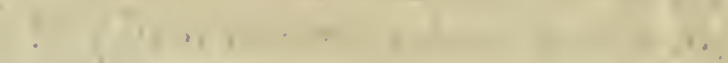

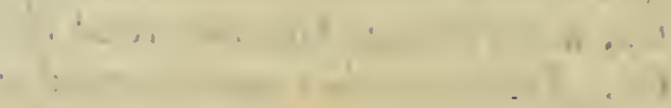

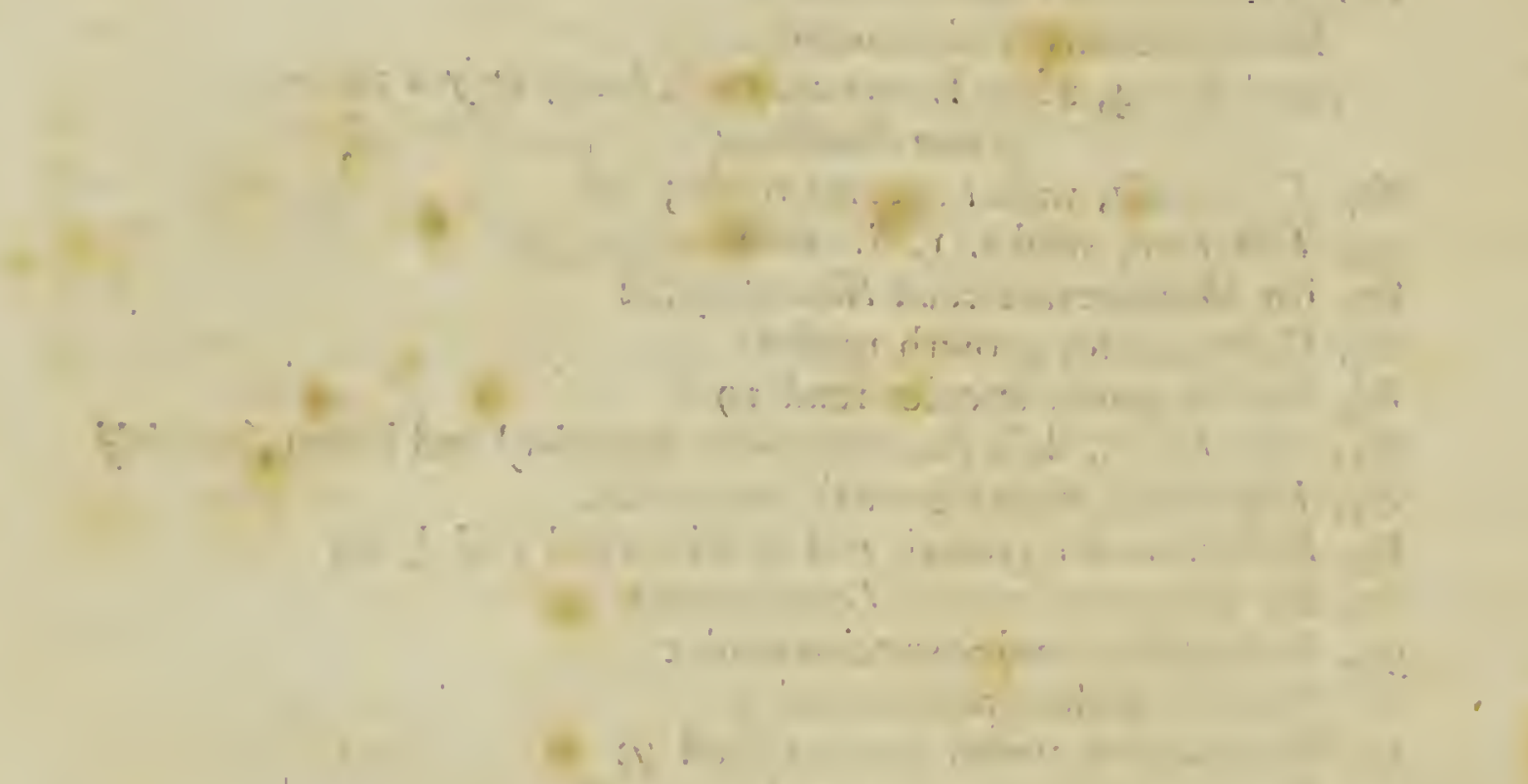

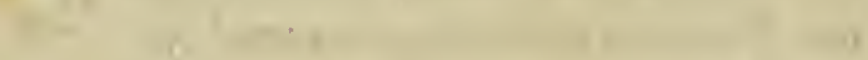

$$
\begin{aligned}
& c_{\mathrm{i}} \ldots, \ldots, \ldots
\end{aligned}
$$

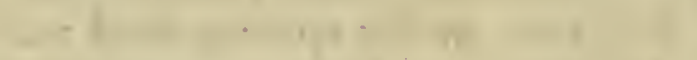

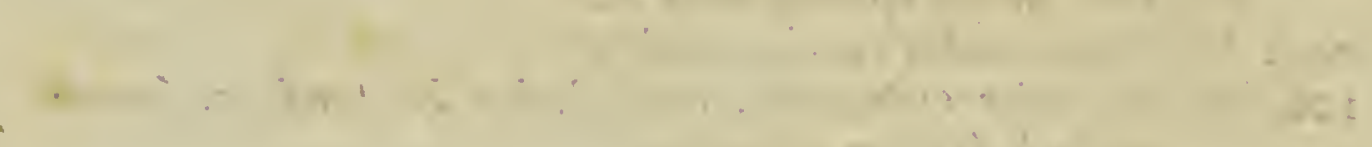

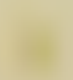

$$
\begin{aligned}
& \text { r ti' , . }
\end{aligned}
$$

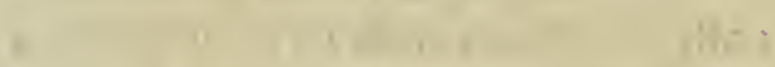

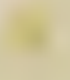

$$
+y^{+}+1, \quad: \quad, \quad+1
$$

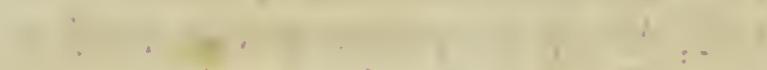

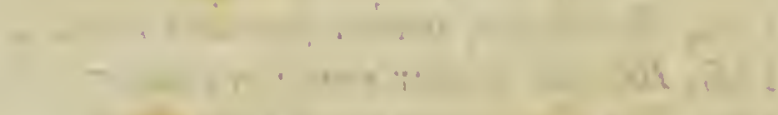

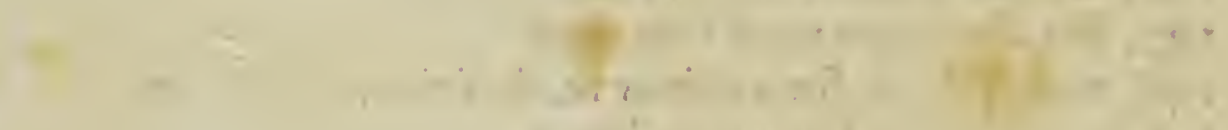

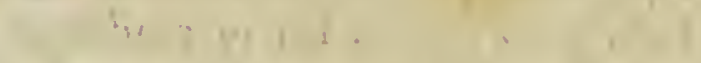

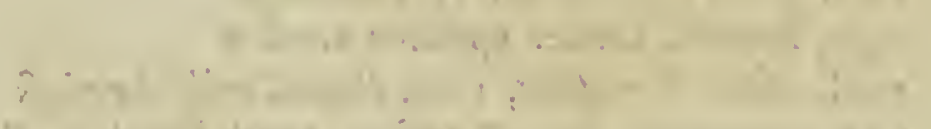

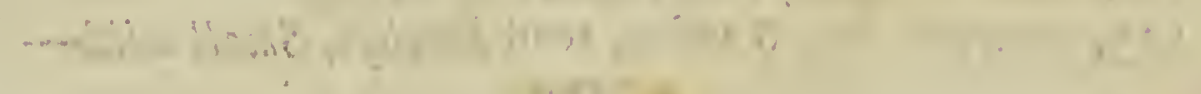

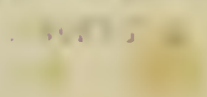




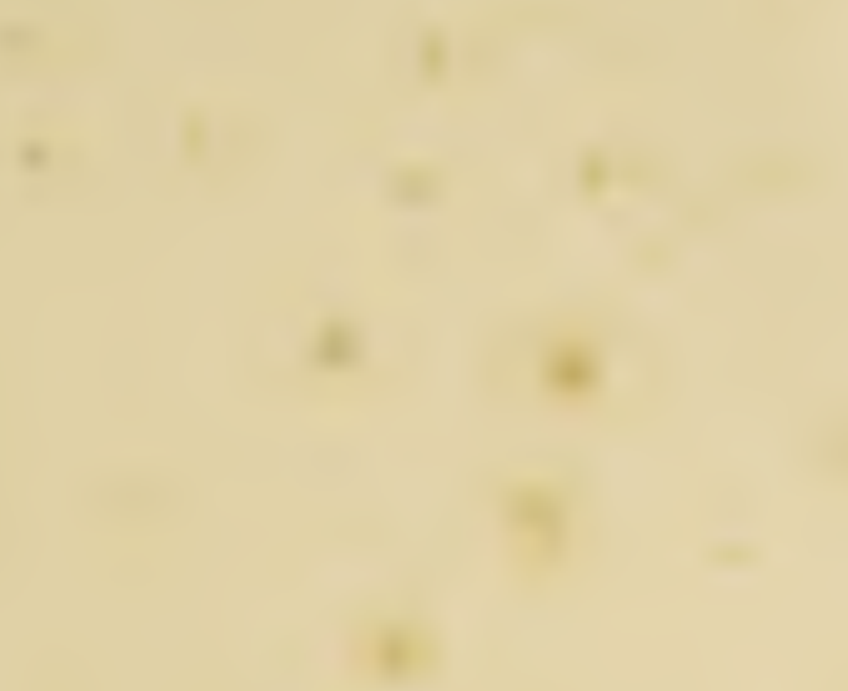

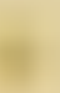






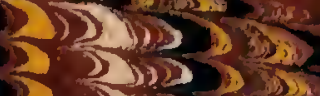
35030 $32 \times 13$

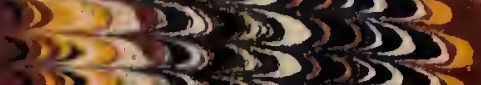

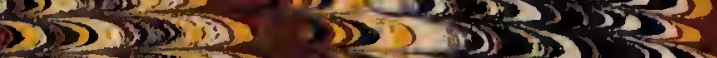

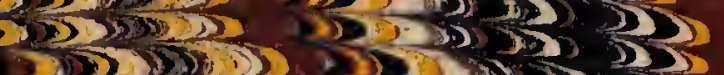

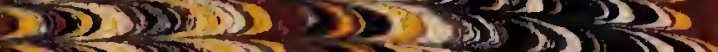

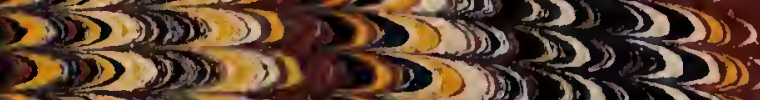

3.25020

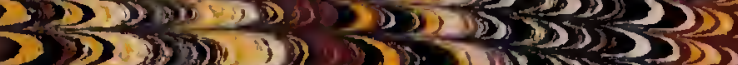
332.20202015025 $322>35 \%$

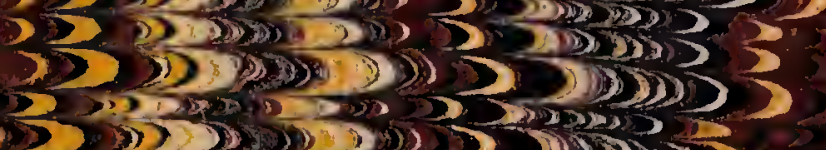

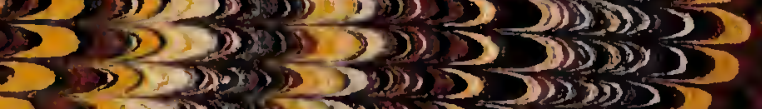

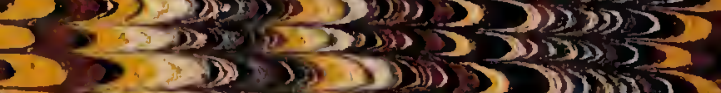

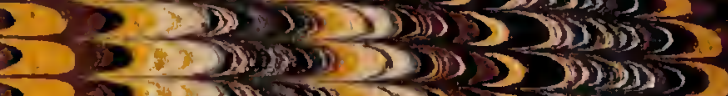

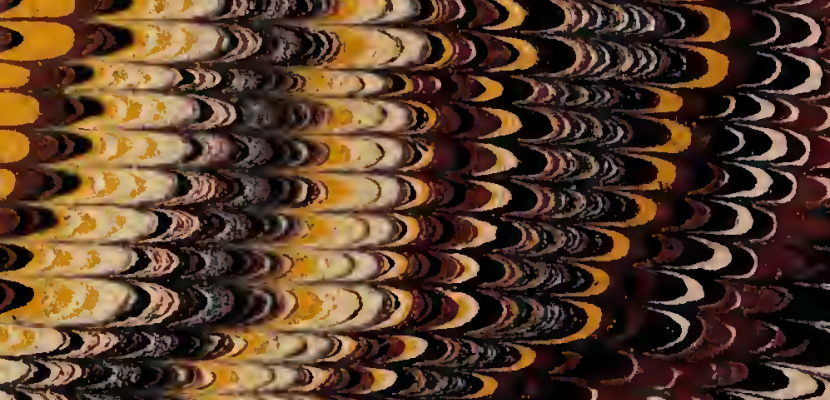
355

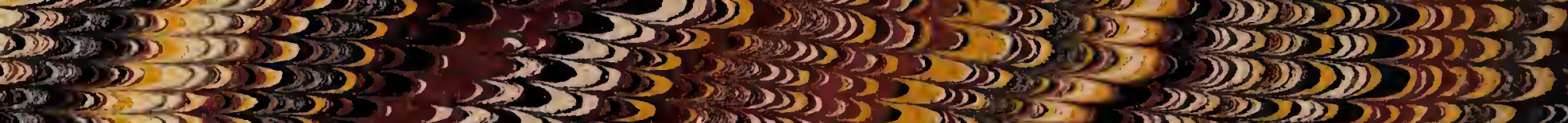

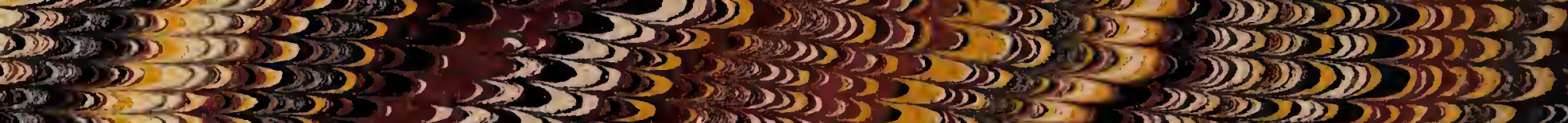

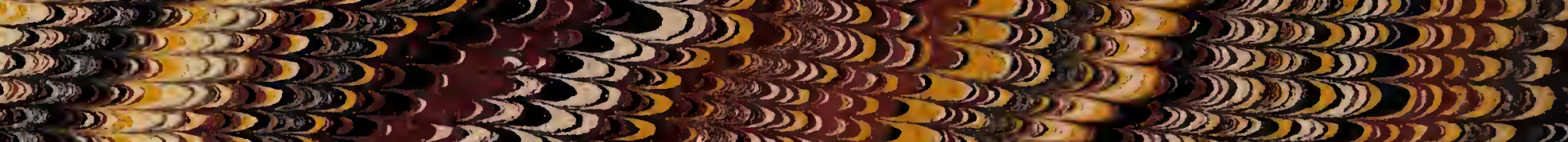

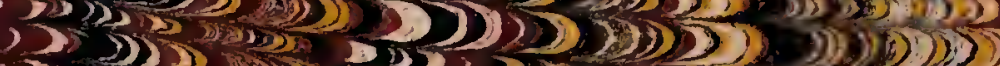

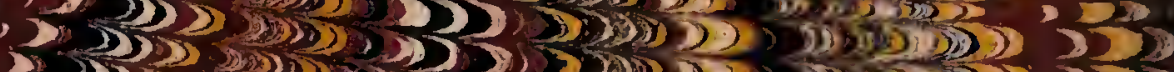

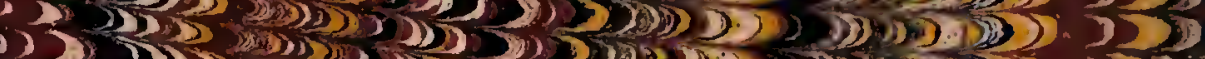

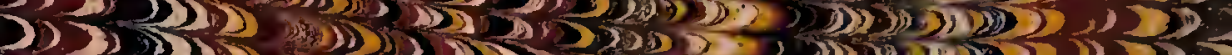

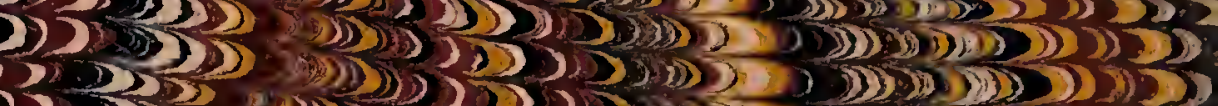

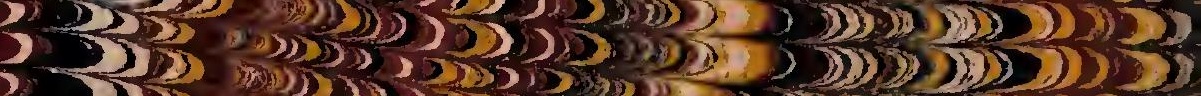
) 31325 1). $20.5 \%$ D) $525053 \times 2 \times$

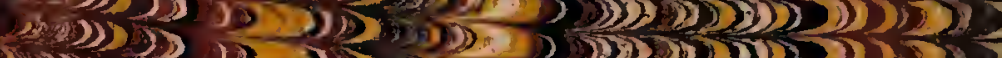

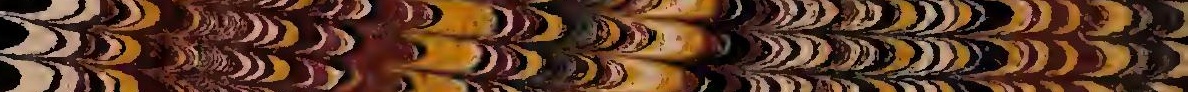

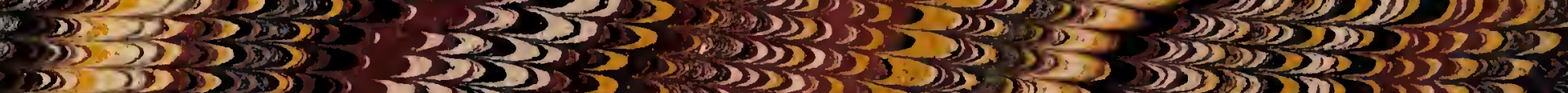

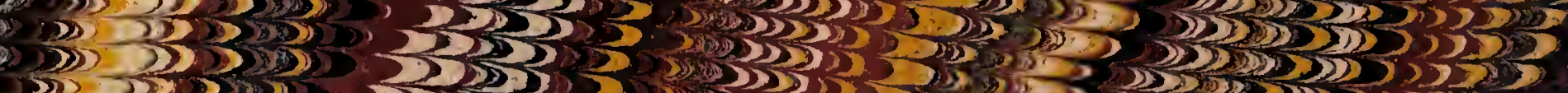

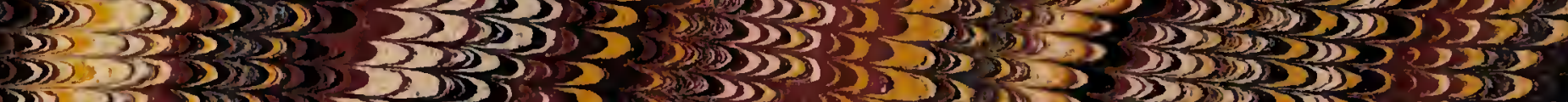

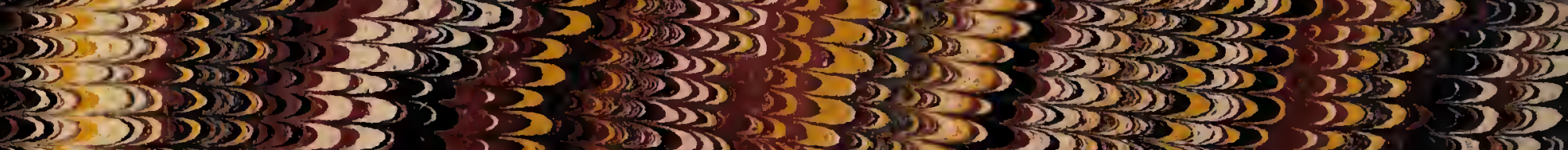

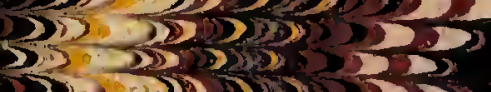

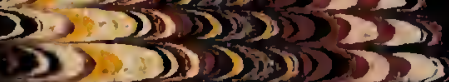
5.51502035

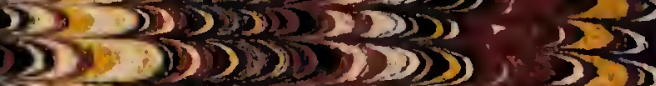

350335,20253503

$20335325 \leqslant 353$

$(3,5), 0301252$

$05,20,020202$

(3) 503020 302325 303535 203515352 3) 55353

(2) i) 1235350 20253532 32.5253

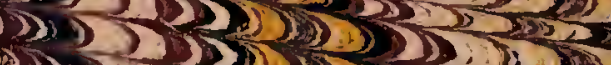

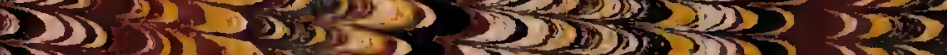

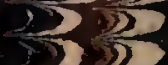

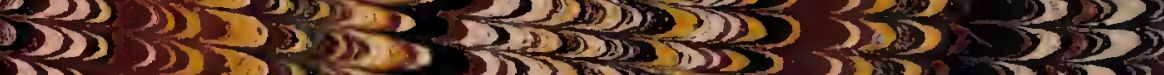

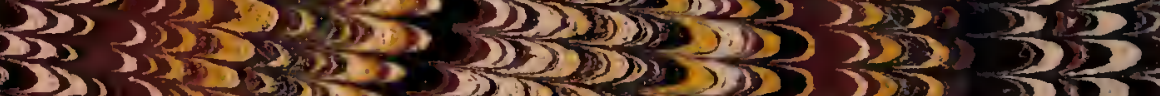
i. T.13

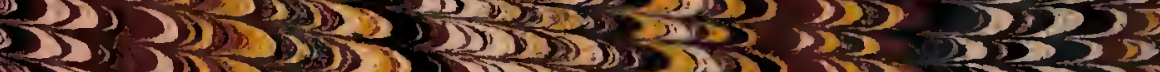

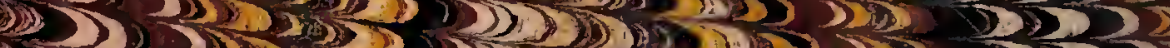

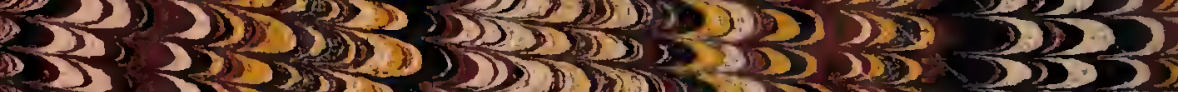

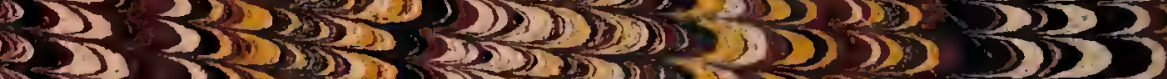

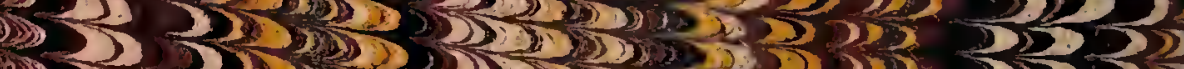

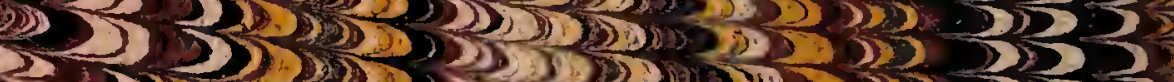

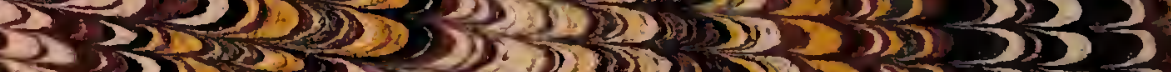

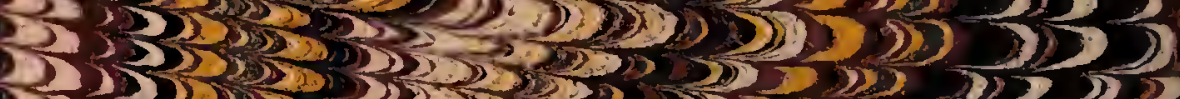

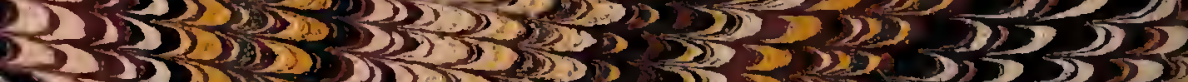

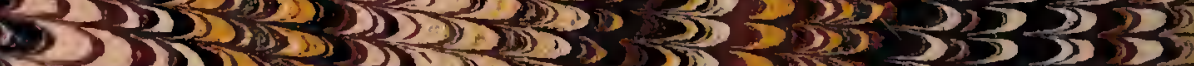

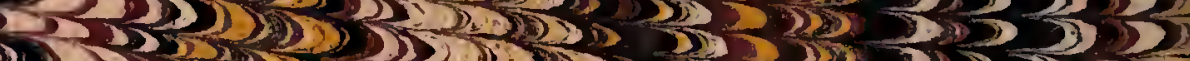

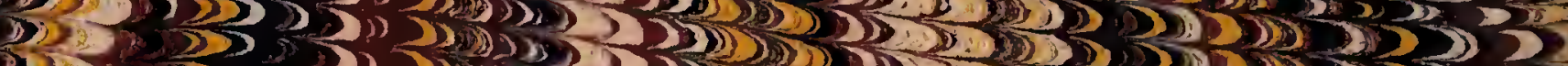

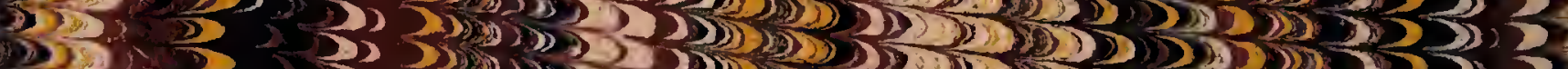

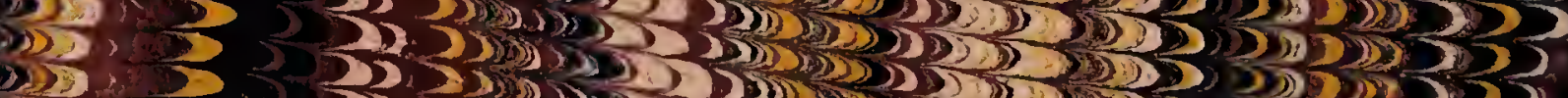

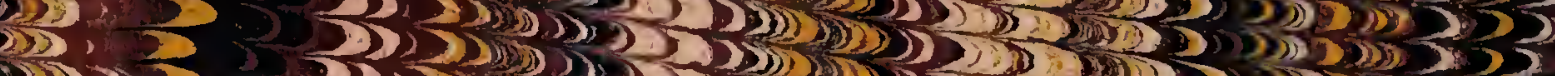

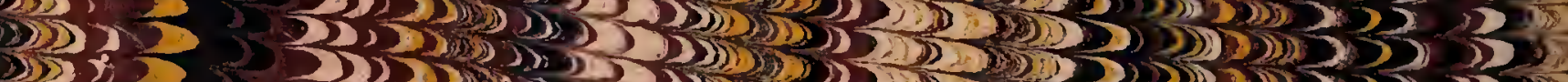
D) 32

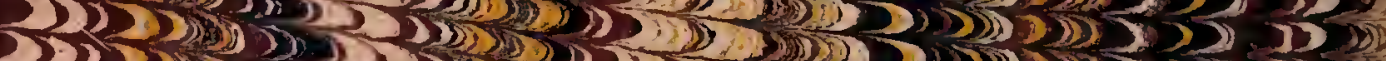

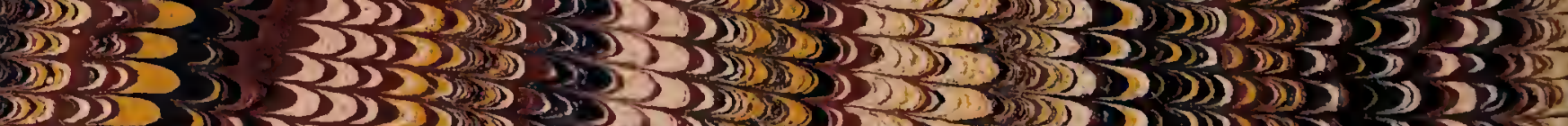

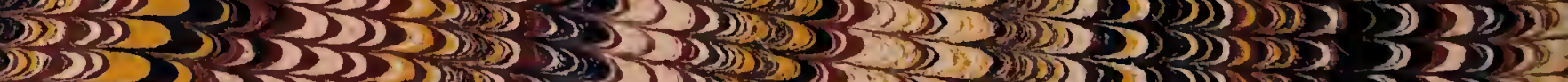

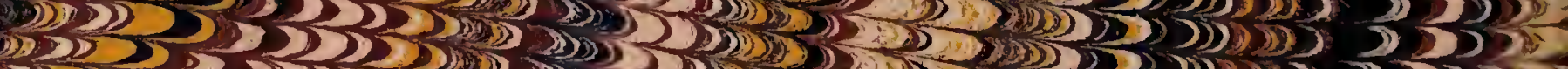

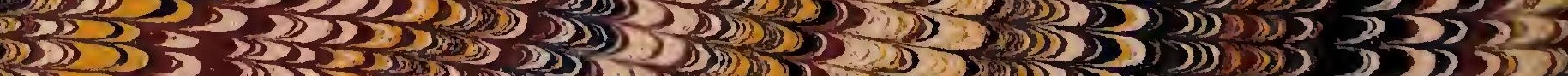

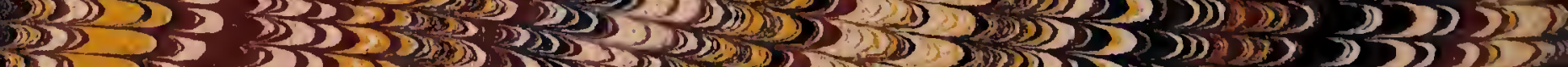

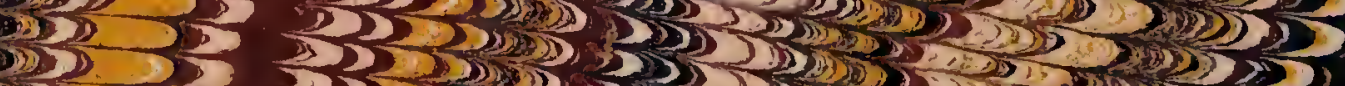

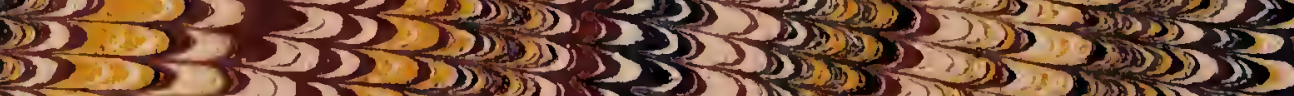

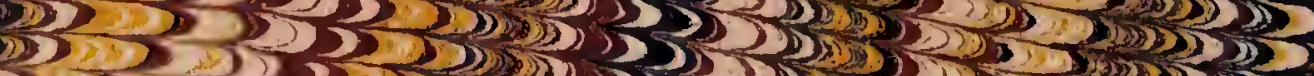

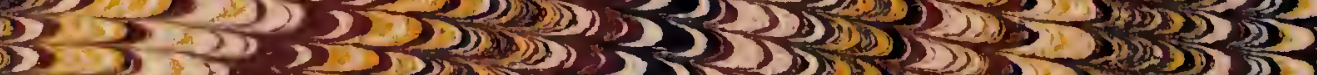

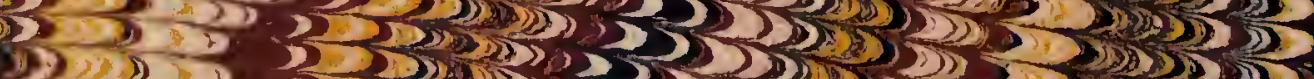

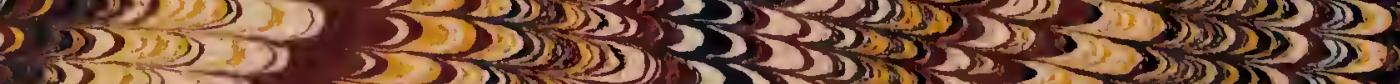

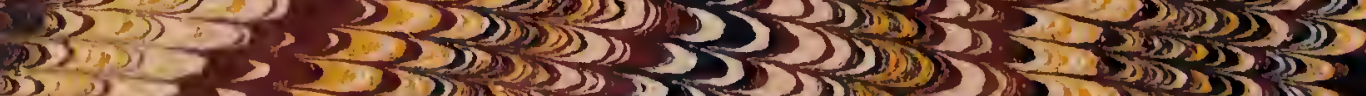

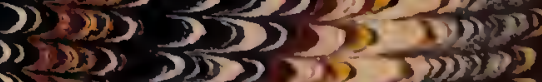

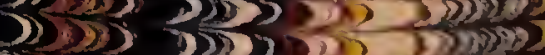

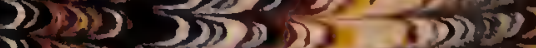
$25>525$

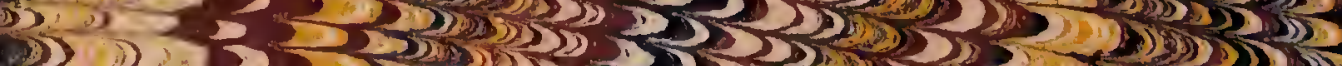





\section{MVYMYMO

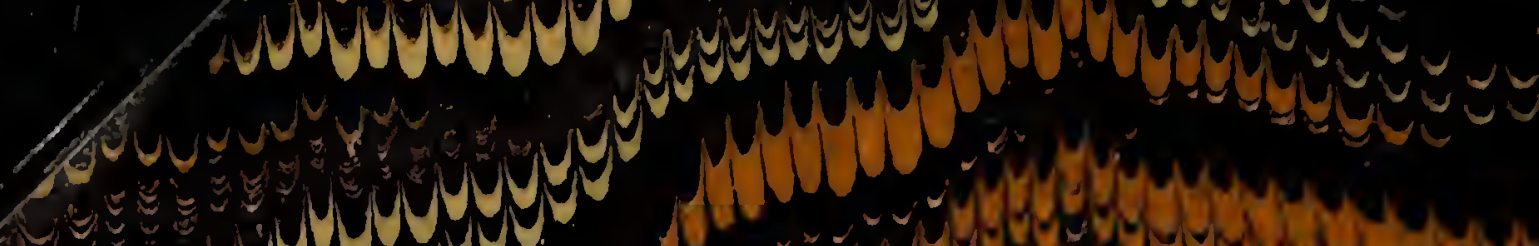

MH

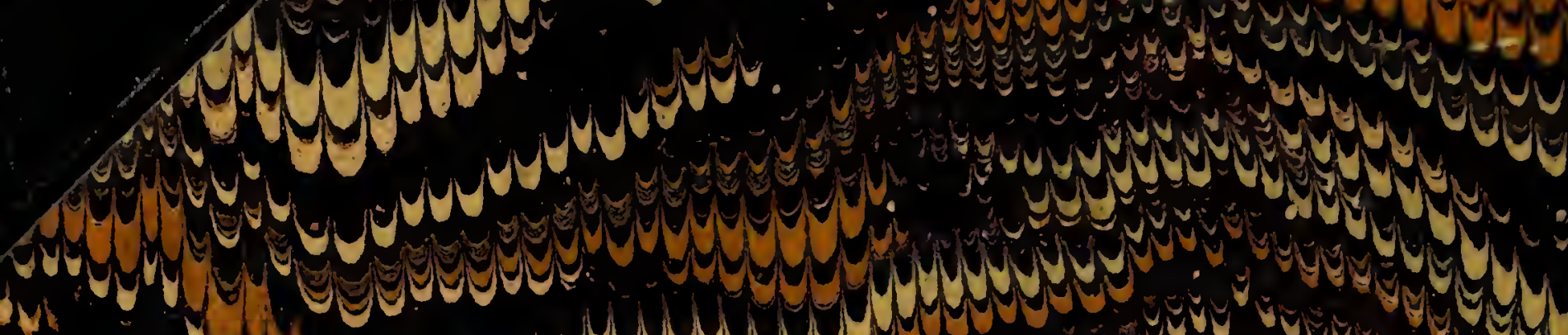

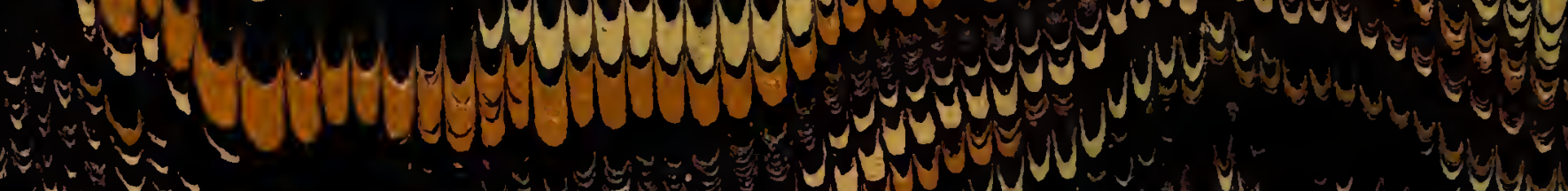

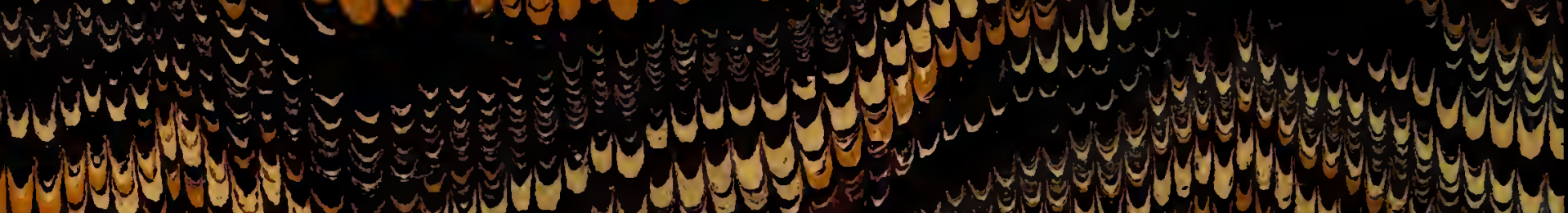

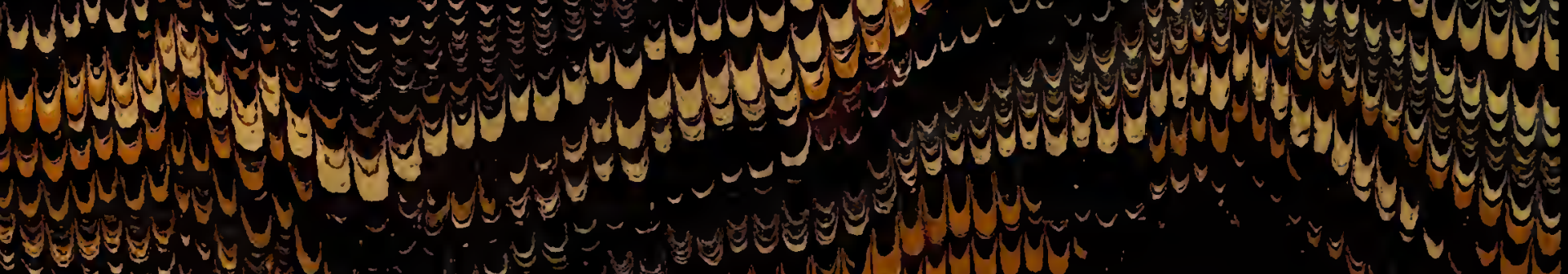

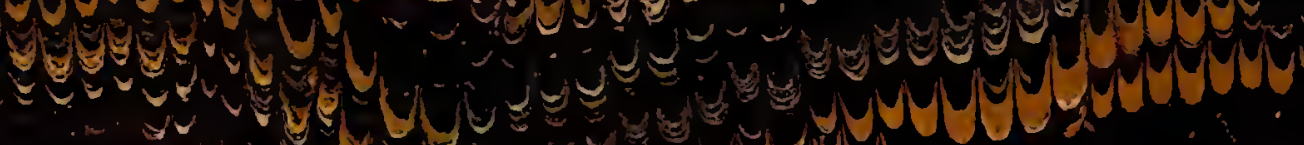

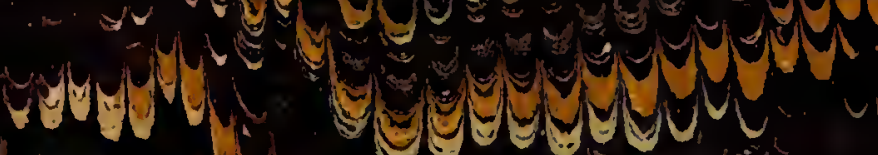

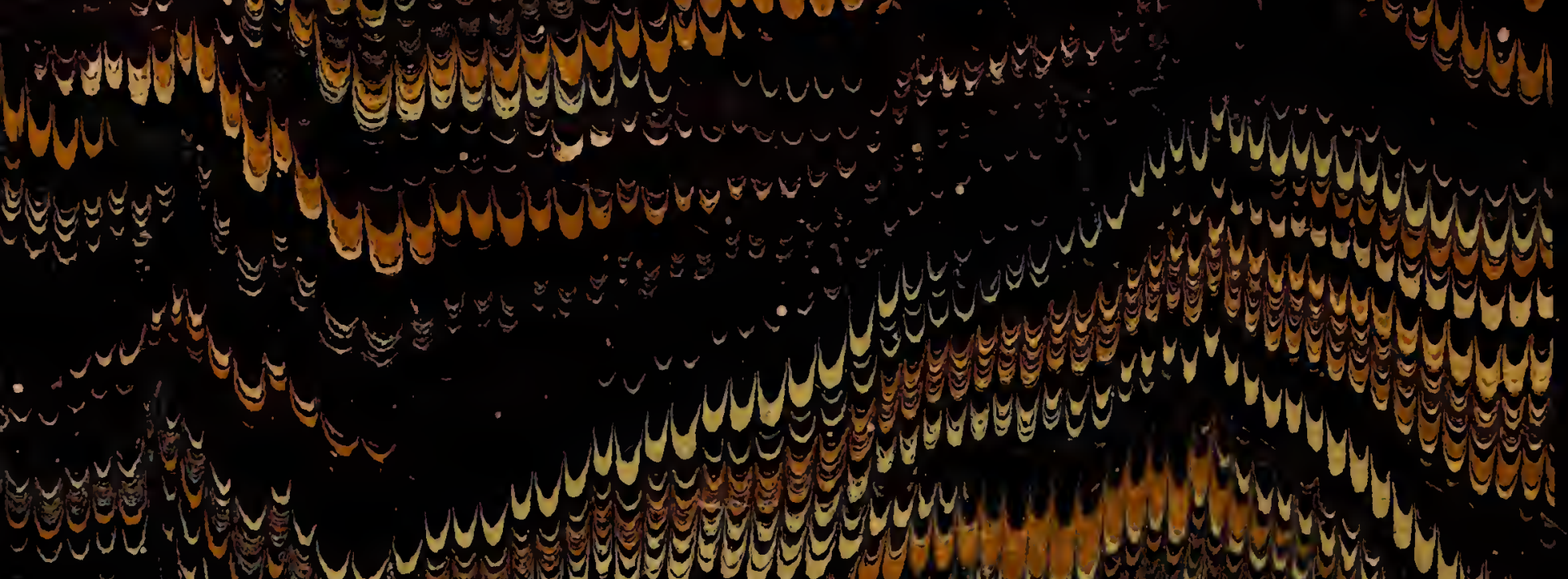

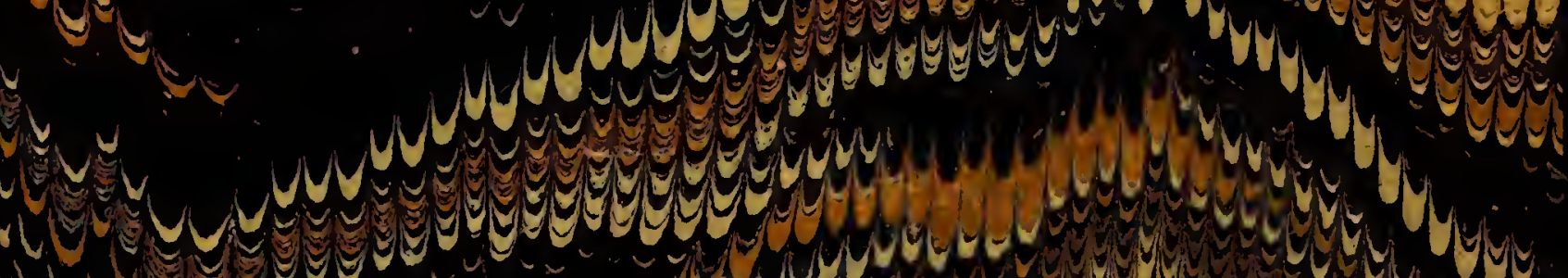

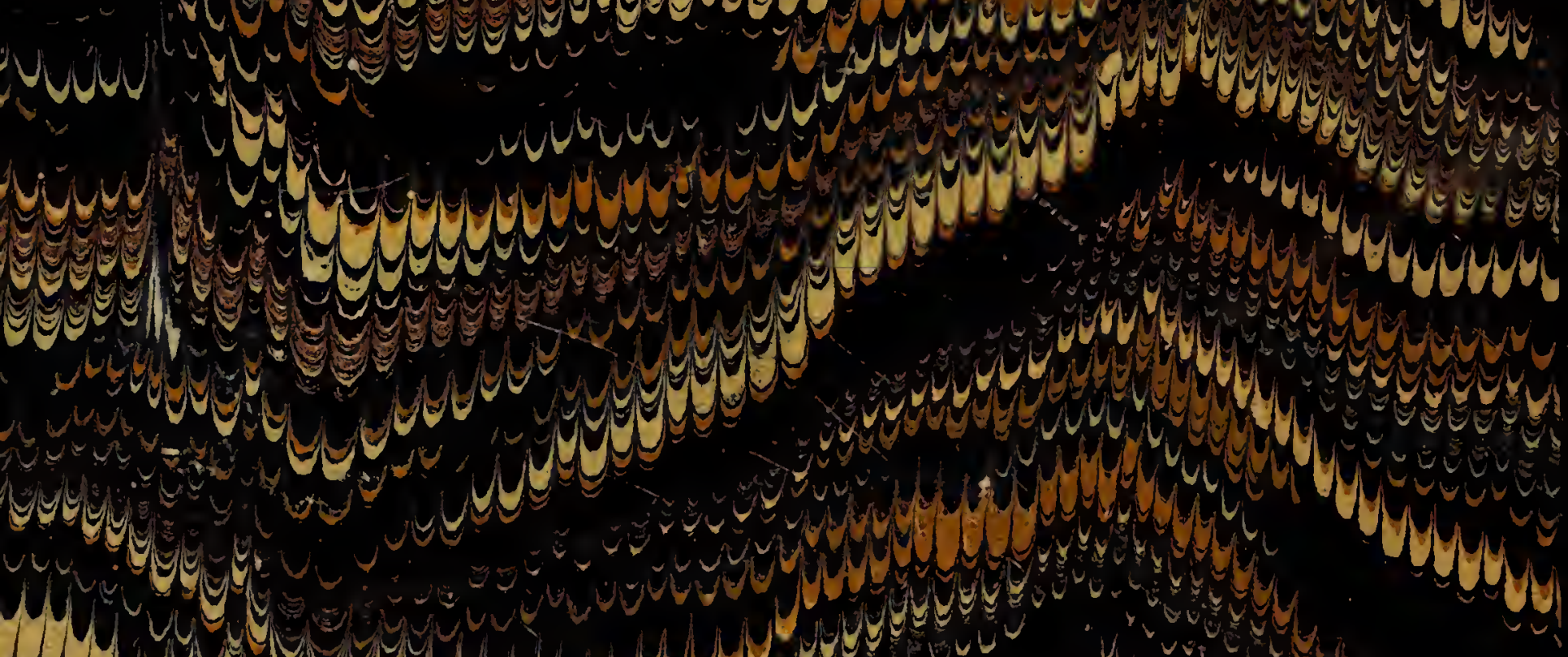

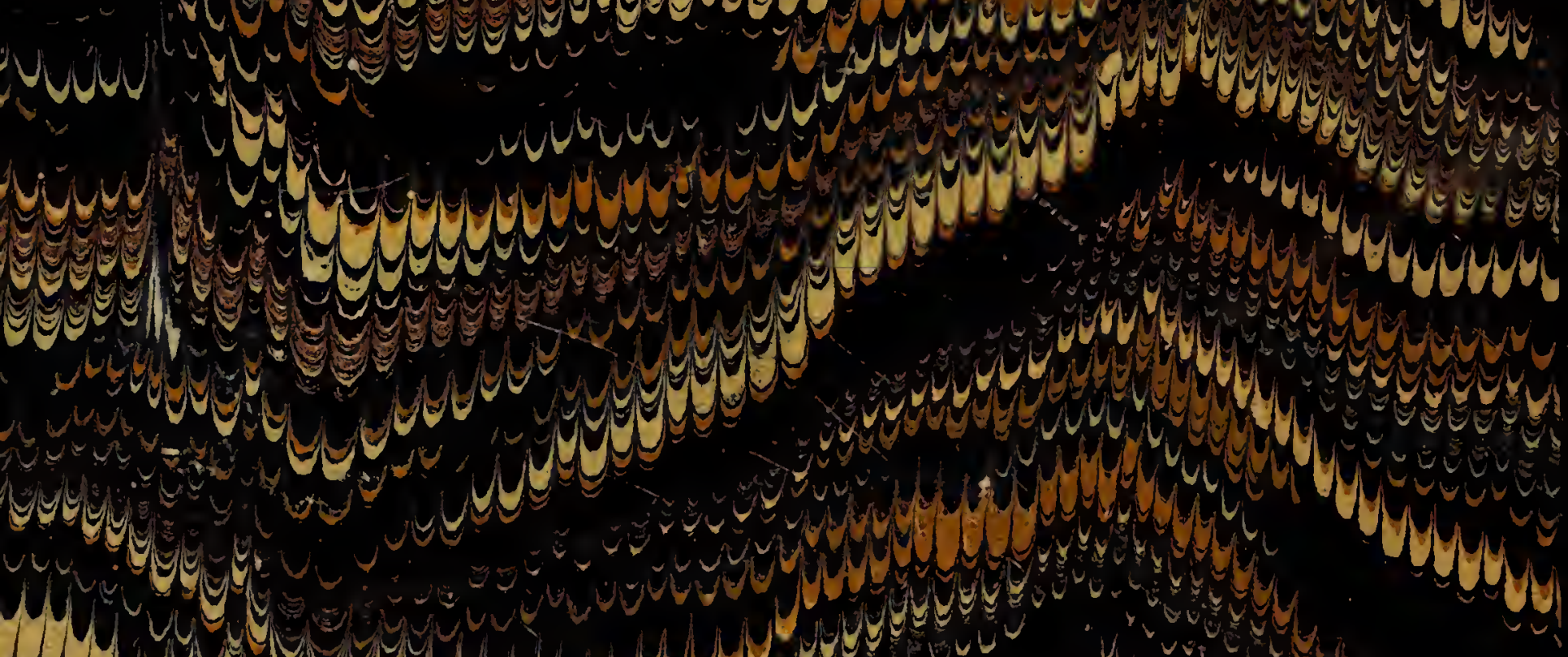

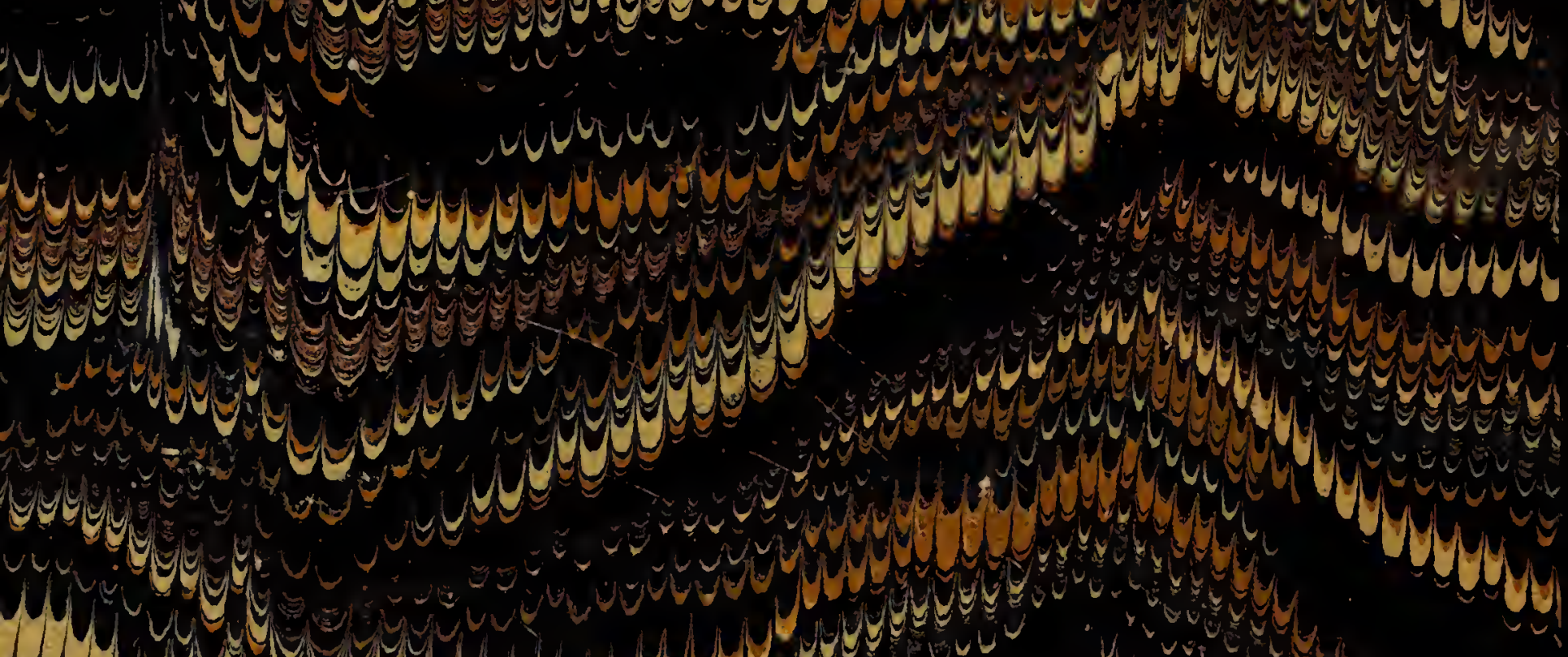

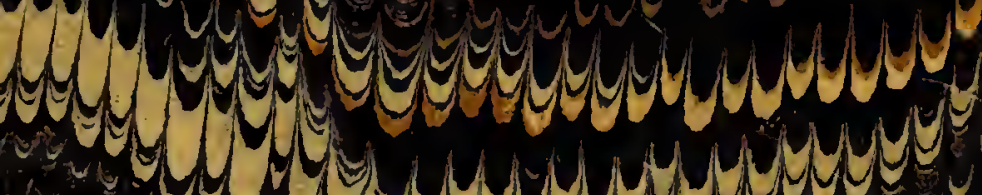

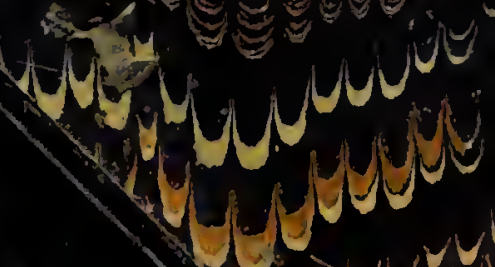

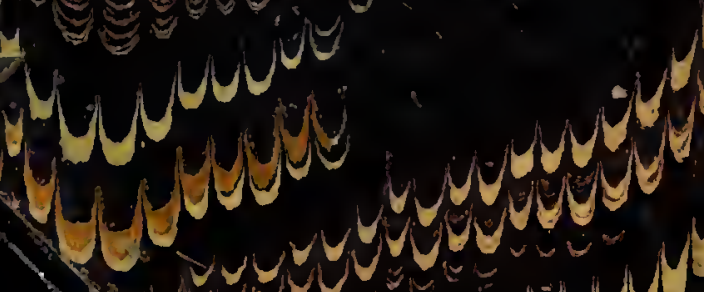

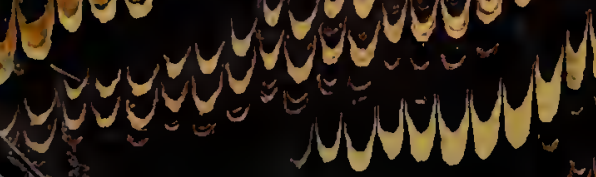

yoy Moly 